\title{
Uranium-Vanadium Deposits of the Slick Rock District, Colorado
}

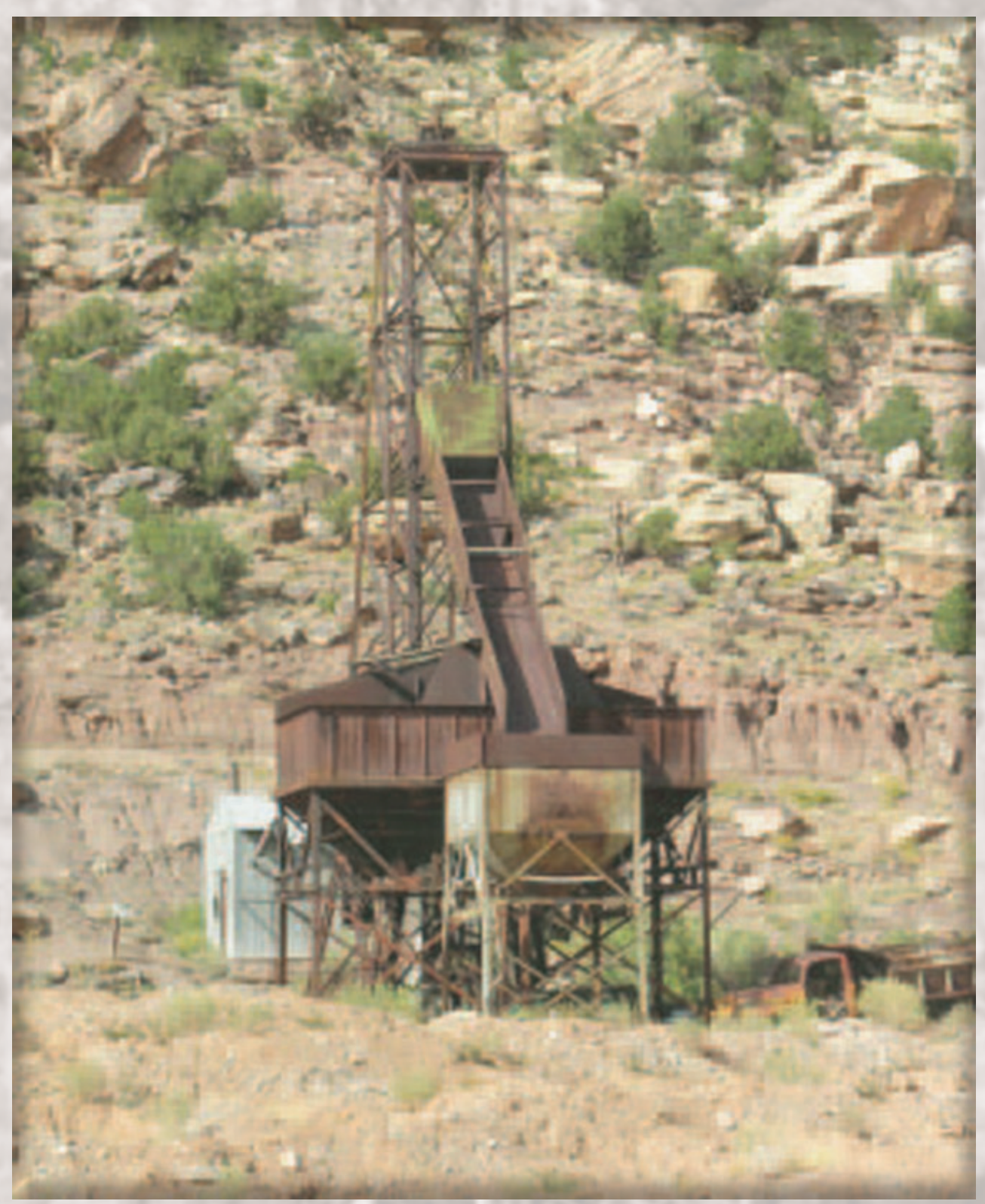

U.S. Geological Survey Professional Paper 576-F

U.S. Department of the Interior

U.S. Geological Survey 
Cover photograph: Burro No. 7 mine, Slick Rock, Colorado. Photograph by Jim Cappa, 2005. 


\section{Uranium-Vanadium Deposits of the Slick Rock District, Colorado}

By Daniel R. Shawe

With a section on Appendix on District Production By William L. Chenoweth

GEOLOGIC INVESTIGATIONS IN THE SLICK ROCK DISTRICT, SAN MIGUEL AND DOLORES COUNTIES, COLORADO

\section{GEOLOGICAL SURVEY PROFESSIONAL PAPER 576-F}

Prepared on behalf of the U.S. Atomic Energy Commission (now Department of Energy)

Detailed comprehensive study of the uranium-vanadium deposits and

their host rocks contributes to the understanding of the origin and

formation (genesis) of the deposits. 


\title{
U.S. Department of the Interior \\ KEN SALAZAR, Secretary \\ U.S. Geological Survey \\ Marcia K. McNutt, Director
}

\section{U.S. Geological Survey, Reston, Virginia: 2011}

\author{
For more information on the USGS — the Federal source for science about the Earth, its natural and living resources, \\ natural hazards, and the environment, visit http://www.usgs.gov or call 1-888-ASK-USGS \\ For an overview of USGS information products, including maps, imagery, and publications, \\ visit http://www.usgs.gov/pubprod \\ To order this and other USGS information products, visit http://store.usgs.gov
}

\begin{abstract}
Any use of trade, product, or firm names is for descriptive purposes only and does not imply endorsement by the U.S. Government.

Although this report is in the public domain, permission must be secured from the individual copyright owners to reproduce any copyrighted materials contained within this report.
\end{abstract}

Suggested citation:

Shawe, D.R., 2011, Uranium-vanadium deposits of the Slick Rock district, Colorado: U.S. Geological Survey Professional Paper 576-F, 80 p., 20 plates. 


\section{Contents}

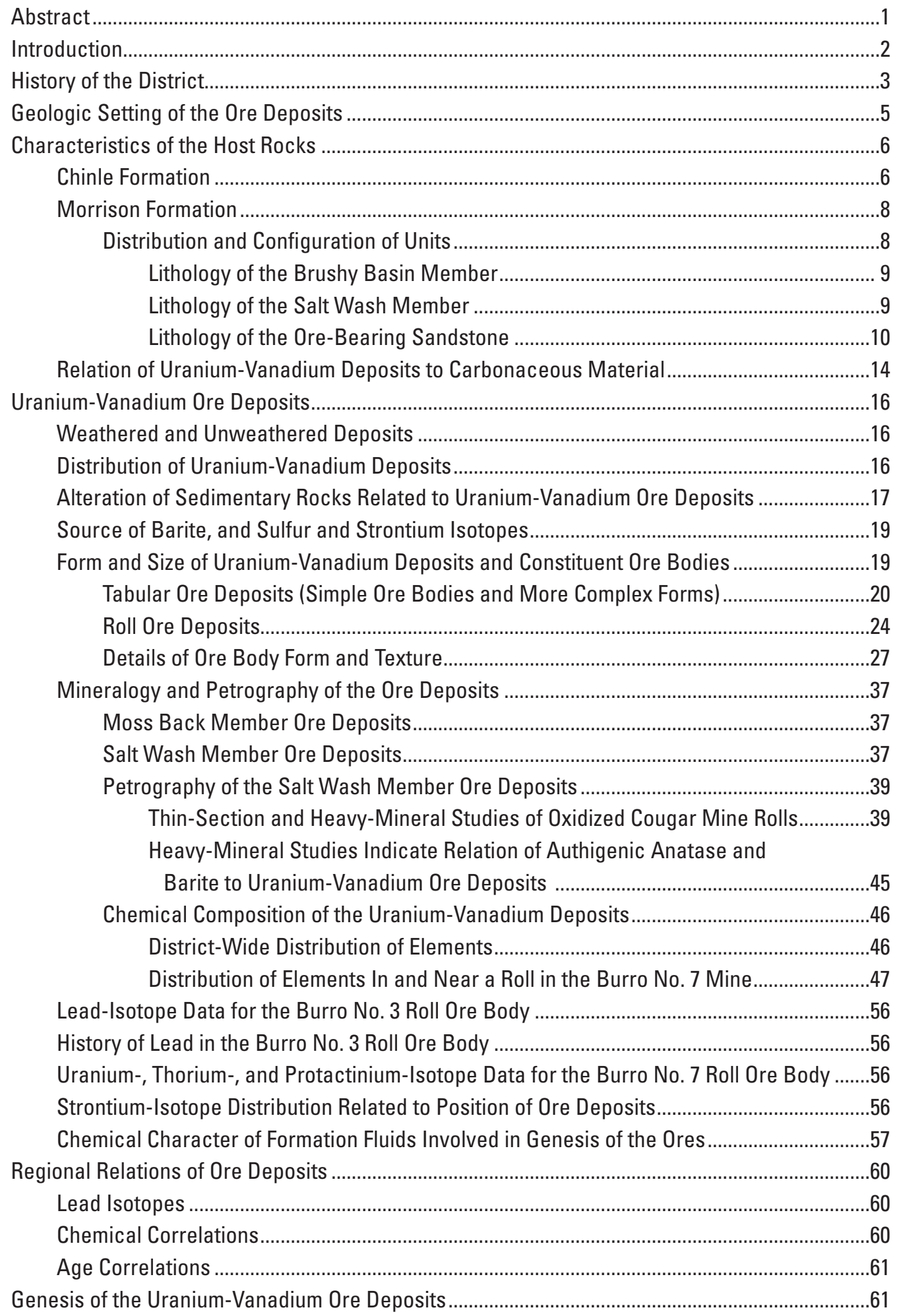




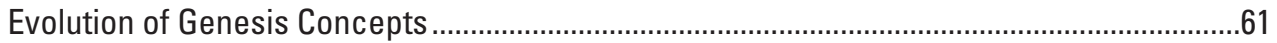

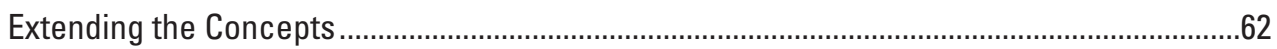

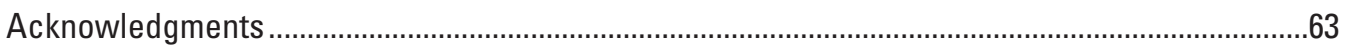

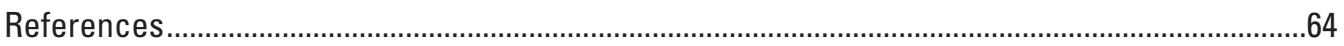

\section{Appendices}

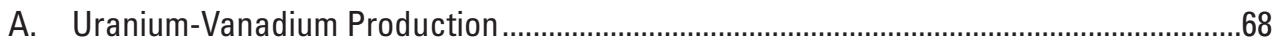

B. Account of Mining in the Slick Rock District, 1965 ..........................................................

C. Chemical Formulas of Minerals Described in this Report ...............................................80

\section{Figures}

1. Index map showing location of the Slick Rock district ..................................................

2. Generalized geologic map of the Slick Rock district.........................................................

$3 A$. Photograph of the ore-bearing sandstone showing lateral variations ...........................10

$3 B$. Photograph of the ore-bearing sandstone showing intertonguing nature of Salt Wash Member and overlying Brushy Basin Member...........................................10

4. Silicified log imbedded in the ore-bearing sandstone ...................................................14

5. Carbonized, silicified, and mineralized dinosaur bone imbedded in the ore-bearing sandstone

6. Cross section of part of the ore-bearing sandstone showing carbonaceous material concentrated in bedding layers.

7. Cross section of part of the ore-bearing sandstone showing carbonaceous material, claystone pebbles, and limestone nodule in sandstone

8. Sketch of the ore-bearing sandstone in rim exposure showing roll ore bodies localized above a basal channel scour.

9. Cross-sectional sketch of a tabular uranium-vanadium ore body in the Moss Back Member

10. Perspective cutaway diagram of the ore deposit at the Ike No. 1 mine, Incline No. 1, Radium group of mines

11. Perspective cutaway diagram of the ore deposit at the King No. 4 mine, Legin group of mines.

12. Perspective geologic cross sections of roll ore bodies, Cougar mine, Lower group of mines.

13. Perspective cutaway diagram of roll ore bodies, Cougar mine

14. Perspective view of part of a roll deposit showing sinuous interconnecting surfaces of rolls, Cougar mine

15. Diagrammatic cross section of rolls in sandstone layers at the base of the ore-bearing sandstone, Cougar mine.

16A. Photograph of axial loops in a mined-out roll at the top of the Salt Wash Member, Radium group of mines

16B. Sketch of photograph illustrated in figure $16 \mathrm{~A}$ 
17. Photograph showing perspective view of the inner (concave) surface of a mined-out roll, Cougar mine.

18A. Photograph showing direct view of the inner surface of mined out roll

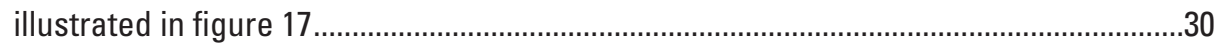

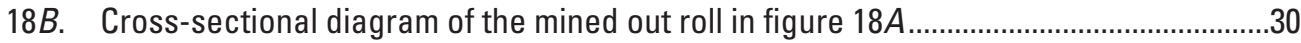

19A. Photograph of roll surface in the Cougar mine...................................................................31

19B. Sketch diagram of the roll showing details of the relation of uranium-vanadium

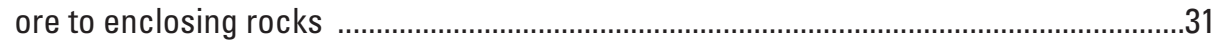

20. Cross-sectional diagram of a small roll-like hump in a thin tabular layer of uranium-vanadium ore, Cougar mine

21. Cross-sectional sketch of a roll ore body showing irregularly curved roll surface, Cougar mine

22. Chalcocite nodule in barren sandstone beneath mudstone and near a flat roll,

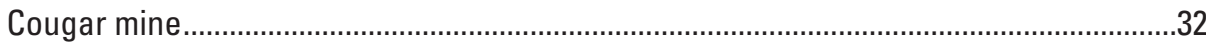

23. Cross-sectional sketch diagram of two juxtaposed rolls.................................................33

24. Cross-sectional sketch of a uranium-vanadium ore layer in flat-bedded sandstone in the Cougar mine

25. Cross-sectional sketch of an ore roll showing layering of ore mineral concentric with the concave surface of the roll, Cougar mine

26. Cross-sectional sketch of a compound roll showing two opposing rolls merged at their upper convex margins, Cougar mine

27. Cross-sectional sketch of a roll ore body remnant showing textural variations related to bedding characteristics of sandstone, Cougar mine.......................35

28. Photograph of "rattlesnake" ore from the Sun Cup mine ................................................35

29. Photograph of "striped" ore from the Sun Cup mine.........................................................36

30. Cross-sectional sketch of Liesegang ring-like layers of uranium and vanadium minerals below a thin tabular layer of ore, Burro No. 1 mine

$31 A-C$. Diagrams of three oxidized roll ore bodies showing distributions of heavy minerals, and locations of thin sections

32. Pen-and-ink drawing of mineralized sandstone, thin section sample C-29, Cougar mine.

33. Pen-and-ink drawing of barite replacing quartz in mineralized sandstone, thin-section sample C-30, Cougar mine.

34. Pen-and-ink drawing of mineralized sandstone, thin section sample C-30, Cougar mine.

35. Pen-and-ink drawing of sandstone partly replaced by chalcocite, thin section sample SH-3, Cougar mine

36. Pen-and-ink drawing of sandstone impregnated and partially replaced by chalcocite, thin section sample C-I, Cougar mine.

37. Pen-and-ink drawing of hydrated iron oxide pseudomorphs of pyrite in a copper-rich veinlet near uranium-vanadium ore, thin section sample C-2A, Cougar mine

38. Map of the north part of the Slick Rock district showing major structural features and amounts of copper in uranium-vanadium deposits.

39. Map of the north part of the Slick Rock district showing major structural features and amounts of lead in uranium-vanadium deposits. 
40. Map of the north part of the Slick Rock district showing major structural features and amounts of molybdenum in uranium-vanadium deposits

41. Map of the north part of the Slick Rock district showing major structural features and amounts of nickel in uranium-vanadium deposits

42A-M. Diagrams showing inferred distributions of elements in an unoxidized ore roll in the Burro No. 7 mine: $A$, uranium; $B$, vanadium oxide; $C$, iron; $D$, titanium; $E$, chromium; $F$, silver; $G$, lead; $H$, molybdenum; $I$, selenium; $J$, copper; $K$, sulfur; $L$, zinc; and $M$, barium

43. Diagram of an unoxidized ore roll in the Burro No. 3 mine, showing locations of samples for which lead-isotope compositions were determined

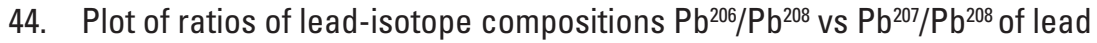
mineral samples from various locations

\section{Plates}

1. Map of the north part of the Slick Rock district and adjacent area showing areas of mined ore deposits Online

2. Map showing locations of diamond-drill holes in the Disappointment Valley area, Slick Rock district. Online

3. Diagrammatic cross section showing carbonaceous material in the orebearing sandstone; $A-A^{\prime}$ on plate 2 . Online

4. Geologic sketch map and cross sections of the underground workings at the Strawberry Roan mine south of the Legin group of mines (SM-2, pl. 1). Online

5. Simplified geologic map of the underground workings, Cougar mine area, showing distribution of roll ore bodies within the braided-stream pattern of sandstone lenses (SM-13, pl. 1) Online

6. Geologic map and generalized sections of the underground workings, Norma Jean No. 2 mine and Belmont claim, Spud Patch group of mines (SM-13, pl. 1). Online

7. Geologic maps and generalized geologic sections of the underground workings, Little Max and Sunday mines, Spud Patch group of mines (SM-13, pl. 1). Online

8. Geologic map and cross sections of the underground workings,

Ike No. 1 mine, Radium group of mines (SM-5, pl. 1) Online

9. Geologic map and cross sections of the underground workings, King No. 4 mine, Legin group of mines (SM-2, pl. 1) Online

10. Geologic sketch map of the underground workings, Brighton mine, Radium group of mines (SM-5, pl. 1) Online

11. Geologic map and generalized cross sections of surface and underground workings, Mayday mine, Spud Patch group of mines (SM-13, pl. 1)

12. Geologic map of the underground workings, Frenchy Incline mine, Legin group of mines (SM-2, pl. 1) Online

13. Geologic map and generalized cross sections of surface and underground workings, Moqui Jug and Depression claims, Spud Patch group of mines (SM-13, pl. 1) 
14. Geologic map of uranium-vanadium roll axes, faults, and sedimentary structure exposed in the underground workings of the Cougar mine area, Lower group of mines (SM-9, pl. 1) ....................................................................... Online

15. Perspective cross sections through the ore deposit at the Cougar mine, Lower group of mines (SM-9, pl. 1). Online

16. Perspective cutaway diagram of the uranium-vanadium ore deposit at the Cougar mine, Lower group of mines (SM-9, pl. 1) .................................................. Online

17. Geologic map and cross sections of the underground workings at the Bennie T. mine, Charles T. group of mines (SM-16, pl. 1) ......................................... Online

18. Geologic cross section showing altered facies sandstone and distribution of anatase relative to subhorizontal mineralized layer in the ore-bearing sandstone Online

19. Distribution of barite relative to subhorizontal mineralized layer in the ore-bearing sandstone Online

20. Map of the underground workings, Cougar mine, showing lateral distribution of copper in the uranium-vanadium deposit Online 


\title{
Uranium-Vanadium Deposits of the Slick Rock District, Colorado
}

\author{
By Daniel R. Shawe
}

\section{Abstract}

The area of the Slick Rock district saw the first production of uranium on the Colorado Plateau. Four periods of mining followed, initially for uranium from about 1900 to 1910 , then for radium to about 1923 . Following a decade of inactivity, mining resumed, this time for recovery of vanadium, in the early 1930s until 1944. Mining began again in 1949 for major production of uranium, with vanadium as a byproduct. This period lasted until 1983, ending when the price of uranium went into serious decline. Presently (2008) renewed interest in demand for uranium is pointing toward additional mining in the district.

Upper Triassic Moss Back Member of the Chinle Formation and Upper Jurassic Salt Wash Member of the Morrison Formation are the principal host rocks of uranium-vanadium deposits in the district. Only small deposits are known in the Moss Back. However, favorable stratigraphic and structural settings, similar to those in the Lisbon Valley district, Utah, to the northwest where numerous very large uranium deposits have been mined, make the unit in the Slick Rock district worthy of further evaluation. Numerous large deposits in the Salt Wash have been mined, and the Slick Rock district has been the principal uranium-vanadium producer in the Uravan mineral belt. Most of this report is devoted to the ores in the Salt Wash, located mostly in the north half of the district.

Certain geologic events in the area of the Western United States, from Cambrian to early Tertiary time, influenced provenance and deposition of the sedimentary rocks that were part of the overall genesis of, or which hosted, the Slick Rock uranium-vanadium deposits. Those events shaped not only the character of the rock facies and related pore fluids that were part of the immediate genesis of the deposits, but they also formed rocks and related fluids developed much earlier and in more distant settings that also were part of the genesis.

Critical to origin of the ore deposits was deposition of evaporitic-sapropelic sedimentary units of the Paradox Formation of the Hermosa Group of Middle and Late Pennsylvanian age. Those sedimentary units determined composition of fluids that subsequently accounted for development of altered facies rocks which are spatially associated with the ores.

The upper unit in the Salt Wash Member, the ore-bearing sandstone, is known throughout the Uravan mineral belt as the main host of Salt Wash ore deposits. In the Slick Rock district it consists mostly of fluvial, fine-grained sandstone deposited in meandering channels of a braided stream system. It contains local zones of abundant carbonaceous plant material with which the deposits occur exclusively. Studies of heavy minerals in the Salt Wash and other Mesozoic sandstone and mudstone units in the district indicate three distinctive lithologic facies: a reduced "carbon facies" confined to the zones of carbonaceous plant material, an oxidized "red-beds facies" as the dominant lithologic type, and a chemically reduced "altered facies." The carbon facies and red-beds facies developed in near-surface, diagenetic environments; the altered facies formed during a much later epigenetic event when deeply buried.

Each of the three facies is significant in the genesis of the ore deposits. Much of the Morrison Formation is of the red-beds facies; such rocks in the upper Brushy Basin Member were the likely immediate source of uranium in the deposits. The red-beds facies formed near the ground surface not long after sediment deposition. Carbon facies in the ore-bearing sandstone of the underlying Salt Wash Member provided the chemically reducing conditions that favored accumulation and (or) precipitation of ore components. Altered-facies rocks, developed by alteration of both red-beds facies and carbon facies as a result of introduction of an extraneous solution at a much later time, interacted with water in carbon facies to form the present geometry and mineralogy of the ore deposits. Uranium from volcanic ash in the Brushy Basin was moved incrementally during a protracted period, probably mostly along faults and partly by compaction from weight of overlying Cretaceous sediments, into the underlying ore-bearing sandstone where the uranium was extracted by adsorption upon humates formed from decaying plant material in carbon facies rocks. Biogenic sulfide developed in the zones of decaying plant material during the early stages of burial. Introduced altering solution, following deep burial of the rocks many millions of years later, encroached through permeable fracture zones and sandstone units into the local zones of carbon facies to establish a more or less stable interface between introduced water and formation water in a zone surrounding the carbonaceous material. Chemical differences between the solutions in carbon facies and in encroaching altered facies resulted in 
precipitation of uranium-vanadium minerals, as well as metal sulfides and selenides.

Detailed studies of the forms, internal textures, mineralogy, and chemistry of the Salt Wash uranium-vanadium ore bodies show convincingly that the ores were precipitated at an interface between formation water (strongly reducing carbonfacies fluid) and introduced water (less reducing altered-facies fluid). Inferred contrasting chemical contents of the two fluids (including mostly uranium, uranogenic lead, and sulfur in formation water and mostly vanadium, titanium, iron, chromium, copper, silver, molybdenum, nickel, and common lead in introduced water) account for the resulting chemistry of the deposits. The specific elements also indicate the sources of the elements. The presence of Liesegang-ringlike forms in some of the roll ore bodies suggest diffusion, likely through a gel, as part of the process of deposition.

Magmas which emplaced the La Sal Mountains laccoliths in Utah northwest of Slick Rock, in early Tertiary time, expelled fluids at depth which heated Paradox Formation waters and drove them upward along favorable structural zones into the Slick Rock district as well as elsewhere in the Uravan mineral belt. The reducing waters from the Paradox, with an increment of water expelled from magmas, served as the altering fluids which leached elements (vanadium, titanium, and other elements) from sedimentary rocks, or carried elements from the magmas (copper, silver, selenium, and other elements) that were deposited at the interface between strongly reducing formation water in the Salt Wash Member and less reducing introduced water.

Regional similarities of lead isotopes, chemical compositions, and ages of mineral deposits and igneous bodies within and adjacent to the Colorado Plateau, indicate that the ores were deposited in their present form during latest Oligocene time.

\section{Introduction}

Recent (2006-2008) revival of interest in uranium resources in the United States, spurred by a national effort to increase the use of nuclear power for the generation of electrical energy, has been the impetus for completion of this report on the uranium-vanadium deposits of the Slick Rock district. A large body of observations and data has led to several critical concepts that provide a rational interpretation of origin and formation (genesis) of the deposits. The report presents these observations, data, concepts, and interpretation.

This report on uranium-vanadium ore deposits is the sixth and final in a series describing geologic investigations during 1953-58 in the Slick Rock mining district in southwestern Colorado. The first five reports dealt with stratigraphy of the district and vicinity (Shawe, Simmons, and Archbold, 1968); petrography of the sedimentary rocks (Shawe, 1968); structure (Shawe, 1970); sedimentary rock alteration (Shawe, 1976a); and geologic history (Shawe, 1976b). Other published reports growing out of these studies (Shawe, 1956a, 1956b, 1962, 1969; Archbold, 1959; Shawe, Archbold, and Simmons, 1959; Bowers and Shawe, 1961; Rogers and Shawe, 1962) described the geologic setting as well as some details of the uraniumvanadium ores. More recent studies (Breit and others, 1990; Breit and Goldhaber, 1995; Breit and Meunier, 1990) have clarified aspects of origin and formation of the deposits.

The report consists of a summary of the principal elements of the geology of the district and surrounding areas, as presented in the early reports just referred to, which constitutes the framework for interpretation of the processes of origin and formation of the uranium-vanadium deposits. The data in these reports are extensively supplemented here with details of the forms, textures, and compositions of the ore deposits. Much of that data was obtained during the original project studies, but it is supplemented with more recent unpublished data from other studies.

The terms "ore" and "mineralized" rock are referred to frequently in later discussions of the uranium-vanadium deposits at Slick Rock. Ore is a term applied to mineralized rock that can be mined economically. Mineralized rock (usually sandstone in the Salt Wash Member of the Morrison Formation) contains introduced minerals whose components include elements for which the deposits are mined, in this instance uranium and vanadium.

In addition to descriptive information herein and an evaluation of the genesis of the Slick Rock uranium-vanadium deposits, the report provides detailed information, such as history of the district, mineralogy of the ore deposits, and uranium-vanadium production of the district, much of which has not been fully incorporated in the present analysis, but which may be useful in subsequent investigations by others.

Several important conclusions reported in the papers cited bear critically on understanding the uranium-vanadium ore deposits. Permeable carbonaceous fluvial-sandstone strata of the Moss Back Member of the Chinle Formation were deposited in the district during Triassic time. Small uraniumvanadium deposits are known in these rocks in the district, and numerous large uranium-vanadium deposits occur in the Moss Back northwest of Slick Rock, in Utah. The principal ore-bearing unit of the Salt Wash Member of the Morrison Formation was deposited in the district and throughout the Uravan mineral belt in Jurassic time. Most of this report deals with the ore-bearing sandstone of the Salt Wash. Permeable carbonaceous fluvial sandstone strata locally characterize the ore-bearing sandstone, which hosts most of the deposits in the mineral belt. Some faulting preceded, accompanied, and followed deposition of the terrestrial Mesozoic strata. Permeable zones of fluid movement thus have existed within and between sandstone strata since shortly following sedimentation.

Uranium-vanadium mineralization took place within the few carbonaceous strata interlayered in the red beds, and extensive chemical reduction occurred widely, but locally, in the red beds apparently at the time of mineralization. The extensive reduction of the red beds implies introduction of reducing fluids from an extraneous source. Because 
uranium-vanadium mineralization and reduction of red beds apparently were part of a single episode, I infer that deposition of the deposits, and introduction of at least part of the components of the deposits, were the result of solutions introduced from a source outside the red beds. A source of the voluminous reducing fluid which widely altered the red-bed host rocks and deposited the ores in the Salt Wash and Moss Back Members, in restricted favorable zones characterized by abundant decaying plant material, probably was the underlying Middle and Upper Pennsylvanian Hermosa Group. Additional fluid likely was derived from magmas which intruded into the nearby La Sal Mountains. I earlier speculated (Shawe, 1976a) that part of saline (marine) pore waters driven out of compacting organic mud in overlying Mancos Shale of Late Cretaceous age following deposition, may have been forced downward into underlying strata because of high fluid density and high pore pressure in the Mancos that resulted from the weight of overlying sediments. Based on more complete knowledge of the age of the Slick Rock ores and movement of fluids to the site of ore deposition, I now believe saline water was mobilized by intrusion of magmas, which then moved up to form igneous bodies in the nearby La Sal Mountains. As the magmas passed through evaporite strata of the Paradox Formation of the Pennsylvanian Hermosa Group, fluids were developed which moved upward into Mesozoic red beds in the early Tertiary, accounting for precipitation of the ores near carbonaceous plant material. Whatever the source, these fluids were fundamental to deposition of the uranium-vanadium ores.

The forms, lithologic relations, and detailed mineralogical and chemical character of the ore deposits indicate that they precipitated at an interface between two fluids. A fluid developed within the Morrison Formation (humate-rich formation water that evolved in the vicinity of carbonaceous plant debris) and an extraneous second fluid introduced into the Morrison Formation are believed to have been the interacting fluids. Evidence described in later pages suggests that uranium (and some other elements) in the Slick Rock ore deposits at the time of ore deposition came mostly from humate-rich formation water, and vanadium (and some other elements) came mostly from introduced fluid. This report presents interpretations of origins (sources) of the elements in the ores, and of interactions between the fluids within carbonaceous sandstone strata (the favorable host rocks), which caused deposition (formation) of the uranium-vanadium deposits.

\section{History of the District}

Mining of the near-surface "carnotite" deposits in the Slick Rock district has taken place during four periods, each marked by efforts to recover different metals. Mining of the deeper reduced ores began in the most recent period. During the first decade of mining, starting about 1900, uranium was the chief metal sought, and vanadium was recovered as a byproduct. In the next decade or so, until about 1923, the ores were worked primarily for their radium content. A decade of inactivity followed the mining for radium, and then from the early 1930s until about 1944 the carnotite ores were mined almost exclusively for their vanadium content. After five years of inactivity in the Slick Rock mines, the fourth period of mining started. Exploitation of the carnotite ores had come full cycle in 1949 with resumption of major recovery of uranium, with vanadium as a by-product. Since then mining has progressed to deep levels below the water table where unoxidized ("black") ores are found. Uranium-vanadium production was continuous, with some fluctuation, for more than 3 decades, when all mining in the district again ceased in 1983 owing to the depressed price of uranium. In recent months, circa 2006, renewed interest worldwide in further development of nuclear power has resulted in a rapid rise in the price of uranium which has brought the Colorado Plateau uranium deposits again into sharp focus. This renewed interest (2008-2010) has prompted a thorough re-evaluation of previously unpublished data, and preparation of this report.

The Slick Rock mining district, whose principal producing area was known originally as the McIntyre district, was one of the first in the Colorado Plateau region to attract attention for its deposits of uranium, vanadium, and radium. Kimball (1904), writing in the Engineering and Mining Journal of June 16, 1904, stated "The area lying along the Dolores river and side gulches, in which the mineral [carnotite] is found, are (sic) of sedimentary formation, broken and cut by deep canons and cup-like valleys lying 1,200 to $2,500 \mathrm{ft}$. below the mesa levels. The ore occurs along rims of canons in white or Dakota sandstone [now identified as the Salt Wash Member of the Morrison Formation], usually over a clay bed, in disseminated grains, bedded veins, seams, occasional pockets, and vugs. Near Snyders, on the Dolores river, San Miguel county, great blocks of sandstone of several tons weight that have broken away from the 'rim' are impregnated with carnotite to the extent of probably one to two percent. Several years ago concentration works were established near there, but the enterprise met with indifferent success."

Probably the earliest uranium production from the Colorado Plateau, by the efforts of two Frenchmen, came at about the turn of the twentieth century. In the region now known as the Uravan mineral belt, M. Poulot and M. Voilleque "in 1900 began operating at a copper mine at Cashin in Paradox Valley, where they used leaching vats to extract uranium" (Moore and Kithil, 1916, p. 18), and in 1901 they built a small mill in the McIntyre district, at the mouth of Summit Creek (Coffin, 1921, p. 152). The two Frenchmen formed a company which became known as the Rare Metals Mining and Mfg. Co., of Cashin, Colo., and constructed the mill at an estimated cost of $\$ 8,000$ (Fleck and Haldane, 1907, p. 48). Moore and Kithil (1916, p. 18-19) wrote further that "the mill ran until 1902, and during this time produced about 15,000 lbs of uranium oxide. The mill was started again in 1903 by the Western Refining Co., but ran only until 1904. Shortly afterwards the Dolores Refining Co. built a new mill a short distance from the old one, but after running for some years, it too shut 
down. The concentrate, which was obtained by the Engle process, retained uranium and vanadium only, not the radium. In addition to this concentrate, some ore was shipped during this period. In 1912 the American Rare Metals Co. acquired the mill of the Dolores Refining Co." and was operating it in 1914. The site of this mill was near the Dolores River, opposite the mouth of Burro Canyon.

According to R.C. Coffin (1921, p. 152) carnotite mining in southwestern Colorado was limited almost entirely to the McIntyre district from 1901 to 1904, "and had the recovery of uranium as its primary object and vanadium as a secondary one."

In 1910 radium apparently had succeeded uranium and vanadium as the principal metal sought in the southwestern Colorado carnotite ores, and demand for radium to be used in the treatment of cancer created a new impetus to activity in the district. According to Moore and Kithil (1916, p. 103), during 1913 "Paradox Valley and the surrounding districts in the southwestern part of Colorado were the scenes of the greatest activity since the opening of the carnotite deposits. Most of the mining was done in the districts that were producing ore toward the close of $1912 \ldots$ but...the McIntyre district during the latter part of 1913 was not very active." Moore and Kithil (1916, p. 103) also stated that in 1913 the "plant owned by the American Rare Metals Co., in the McIntyre district, south of Paradox, was in operation to some extent in the early part of the year, but since that time has been shut down. The larger part of the radium concentrates produced by them in 1912 and the early part of 1913 [was] sold abroad in December 1913."

During the first decade or so of activity in the McIntyre district, "mining made only small inroads on the ore supply" and "the larger part of the ore [was] rather low grade" (Moore and Kithil, 1916, p. 29). However, Moore and Kithil (1916, p. 20) wrote that the grade of ore mined between about 1901 and 1910 probably averaged slightly more than 2 percent $\mathrm{U}_{3} \mathrm{O}_{8}$ and between 3 percent and 4 percent $\mathrm{V}_{2} \mathrm{O}_{5}$; this would be high-grade ore for sandstone-type ore deposits by the 1950s. Shipments of concentrates from the district were made by way of the town of Dolores, about $50 \mathrm{mi}$ to the south, which was served by a railroad.

Production from the McIntyre district during the first two years of activity (1901-1902) was probably about 300 tons of uranium-vanadium ore, based on figures from Moore and Kithil (1916). During the following decade until the district became relatively inactive in 1914, average production may have been close to this rate and totaled about 1,500-2,000 tons. However, Coffin (1921, p. 152) implied that little mining was done in the district from 1904-1910. Production during the decade 1918-1928 appears to have been only a few hundred tons of ore, mined for its radium content. Hess (1933, p. 462) reported that "from 1907-1920 the deposits in (the Morrison Formation on the Colorado Plateau) furnished most of the world's radium."

According to Coffin (1921, p. 151), because of the increasing demand for radium, "activity in mining these ores increased each year from 1910 until 1914, when the war
[World War I] stopped their sale. Up to that time they had been largely sold to foreign buyers. After the slump of the carnotite market at the beginning of the war, demand for this ore increased, although not uniformly, until 1919 the quantity of ore mined exceeded that of any previous year". Fischer (1942, p. 364) reported that mining in Montrose County and adjacent areas ceased in 1923, "when the Belgian Congo pitchblende began to supply radium."

By 1915 about 160 mining claims had been staked in the McIntyre district, according to a claim survey by Charles L. Harrington (Coffin, 1921). Apparently many of these claims lapsed following the period of radium mining, and were re-staked under different names when mining activity picked up in the early 1930s, but many of them have survived to the present day with their original names.

The third period of activity in the Slick Rock district, that of vanadium mining, began in about 1931 when the Shattuck Chemical Co. of Denver built a new mill with a capacity of 10 to 15 tons of ore per day, at the site of the American Rare Metals Co. mill near the Dolores River opposite the mouth of Burro Canyon. In 1934 North Continent Mines, Inc. acquired the mill and several groups of claims from the Shattuck Chemical Co. and in 1942 increased the capacity of the mill to 30 tons daily. The mill operated intermittently, but was shut down in 1943, although the company continued mining for about a year. The ore was sold to the Metals Reserve Company until that agency discontinued its ore-buying program. The last shipments of ore were sold to the Union Mines Development Corp., a subsidiary of Union Carbide Corp., in the summer of 1944 (B.N. Webber, Union Mines Development Corp., written commun., 1947). B.N. Webber and colleagues of Union Mines Development Corp., then under contract to the AEC, mapped several mines in the Slick Rock district; some of the maps are used in this report.

According to J.E. Motica of Union Carbide Corp. (written commun., 1959) a mill called the Mesa mill was built in 1938 near Disappointment Creek about one-quarter mile from the Dolores River. The mill operated less than a year.

Important groups of mining claims during the vanadium period were the Spud Patch claims owned by the U.S. Vanadium Corp. and the Vanadium Corp. of America, the Lower and Charles $\mathrm{T}$ groups of claims owned by North Continent Mines, Inc., and the Radium group of claims that was acquired in 1943 by F.A. Sitton from Michael O’Neal.

The district's production of ore for vanadium recovery was chiefly during the late 1930 s and early 1940 s, and totaled probably at least 60,000 tons of ore averaging about 2.5 percent $\mathrm{V}_{2} \mathrm{O}_{5}\left(1,500\right.$ tons $\left.\mathrm{V}_{2} \mathrm{O}_{5}\right)$. Most of this production came from the Spud Patch, Lower, Charles T, and Radium groups of claims, and the remainder came from the Legin, Georgetown, and Upper groups of claims, and the Ellison-Burro claims.

In 1944 some of the mines in the district were worked by the Union Mines Development Corp. for the uranium content of the ores. The ores averaged about 0.25 percent $\mathrm{U}_{3} \mathrm{O}_{8}$ and the uranium was used by the Manhattan District, predecessor 
of the Atomic Energy Commission, in the development and construction of the first atomic bombs.

The old McIntyre district and the Dolores River district farther south were consolidated and became known as the Slick Rock district in the late 1940s, when the U.S. Geological Survey (USGS) began numerous extensive studies that culminated during 1953-1958.

Prior to November 1953, an estimated $87,000 \mathrm{ft}$ of diamond drilling and wagon drilling was done by private industry in the Slick Rock district (Bell, 1950, 1953; Bush and others, 1950; Trace, 1950). From November 1953 to November 1954 , an estimated $125,000 \mathrm{ft}$ of diamond drilling was done by private industry in the district. The U.S. Bureau of Mines drilled about 12,500 ft before 1946 (Huleatt and others, 1946), and the USGS completed about $373,200 \mathrm{ft}$ of diamond drilling by March 1956.

The decade of the 1950s saw considerable activity in the mines of the Slick Rock district, during which time almost $1,000,000$ short tons of ore were mined. These ores averaged about 0.22 percent $\mathrm{U}_{3} \mathrm{O}_{8}\left(2,200\right.$ tons) and 1.7 percent $\mathrm{V}_{2} \mathrm{O}_{5}$ (5,880 tons), and about $\$ 50$ (1950 dollars) per ton in value for the contained uranium and vanadium. Most of the production for this period came from mines in the Burro, SummitMercantile, Lower, Radium, Legin, Georgetown, Middle, and Charles T groups of claims. Major operators during the period were Union Carbide Nuclear Co., Dulaney Mining Co., Skidmore Mining Co., Ortmayer Mining Co., Holling Mining Co., and several independent leasors.

Since 1960 substantial additional drilling has been done, and an additional 1,000,000 tons of ore have been mined, including that from new properties (Deremo, Carnation, and Awold No. 3 mines, Union Carbide Nuclear Co.; Dolores River and Suncup mines, North American Uranium Co.).

A description of mining activity in the district in early 1965 is given in Appendix B.

Most of the mining properties in the Slick Rock district are about 40-50 $\mathrm{mi}$ from the site of a government-operated mill at Monticello, Utah, which closed in about 1960, and the Vancorum Corp. of America uranium mill at Vancorum, Colo., which was shut down in 1957. Some operators shipped ore about $180 \mathrm{mi}$ to the Climax Uranium Co. mill in Grand Junction, Colo., or about $100 \mathrm{mi}$ to the Vanadium Corp. of America mill in Durango, Colo. Following construction of an upgrading mill on Poverty Flat in the Slick Rock district by Union Carbide Nuclear Co. in 1956-1958, some operators delivered ore to this plant. The plant closed circa 1970. Concentrates from this plant were trucked about $250 \mathrm{mi}$ to the Union Carbide Nuclear Co. mill in Rifle, Colo. During the later years of mining in the district, production from the Deremo and Sunday mines was shipped to the mill in Uravan.

Production data for the Slick Rock district up to 1978, compiled by William Chenoweth (Shawe and others, 1991) indicate approximately 9,000 tons of $\mathrm{U}_{3} \mathrm{O}_{8}$ and 50,000 tons of $\mathrm{V}_{2} \mathrm{O}_{5}$ mined. Up to 1978, the district was the largest producer of both uranium and vanadium in the Uravan mineral belt. Production since, up to about 1983, amounted to approximately $4,839,000$ tons of ore, when production virtually ceased (see Appendix A). At present, with renewed interest resulting from the high price of uranium, it seems that uranium exploration and mining in the Slick Rock district are again likely.

\section{Geologic Setting of the Ore Deposits}

The Slick Rock uranium-vanadium district lies in the western parts of San Miguel and Dolores Counties, Colorado, (fig. 1) at the south end of the Uravan mineral belt. Sedimentary rocks that crop out in the district range in age from Permian to Cretaceous (fig. 2) and are as much as $4,700 \mathrm{ft}$ thick. These rocks and older Paleozoic sedimentary rocks that underlie them and rest on igneous and metamorphic rocks of a Precambrian basement total about $13,000 \mathrm{ft}$ thick (see table 1 in Shawe, 1970).

Uranium-vanadium deposits in the district are known in the Moss Back Member at the base of the Chinle Formation (Upper Triassic) and at several levels of the Morrison Formation (Upper Jurassic); important production has come mainly from the top sandstone or so-called "ore-bearing sandstone" of the Salt Wash Member of the Morrison. Locations of mine groups and individual mines known in the 1950s in the Slick Rock district are shown in Shawe and others. (1968, pl. 1). Locations of areas of mines in the district (SM 1-29) as of 1983 are shown on plate 1 of this report, and lists of mines in those areas are given in Appendix A.

The district is in the Paradox Basin at the southeast end of the Paradox fold and fault belt (Kelley, 1958). Major folds in the district are broad and open, trend about N. $55^{\circ} \mathrm{W}$., and are parallel to the collapsed Gypsum Valley salt anticline bounding the northeast edge of the district (fig. 2). The Dolores anticline lies about $10 \mathrm{mi}$ southwest of the Gypsum Valley anticline; the Disappointment syncline lies between the two anticlines.

Several zones of faults traverse the district (fig. 2). One zone bounds the southwest edge of the collapsed core of the Gypsum Valley salt anticline at the northeast margin of the district. A second zone, the Dolores, lies about 2 mi northeast of the parallel Dolores anticline. A few faults form a conjugate set normal to the Dolores zone of faults in the north part of the district. The south part of the district is cut by the Glade zone of faults which trends about N. $80^{\circ}$ E. Prominent joint sets, mostly parallel to individual faults in all the zones of faults, are widespread throughout the district (William B. Rogers, USGS, unpub. data, 1957). Most of the uraniumvanadium deposits in the district form a zone centered on the broad northwest-southeast-trending Dolores ore zone where it is intersected by the conjugate set of northeast-southwesttrending faults.

Much of the faulting occurred after lithification of the Upper Cretaceous sedimentary units in Late Cretaceous-early Tertiary time. The faults were significant because some of 

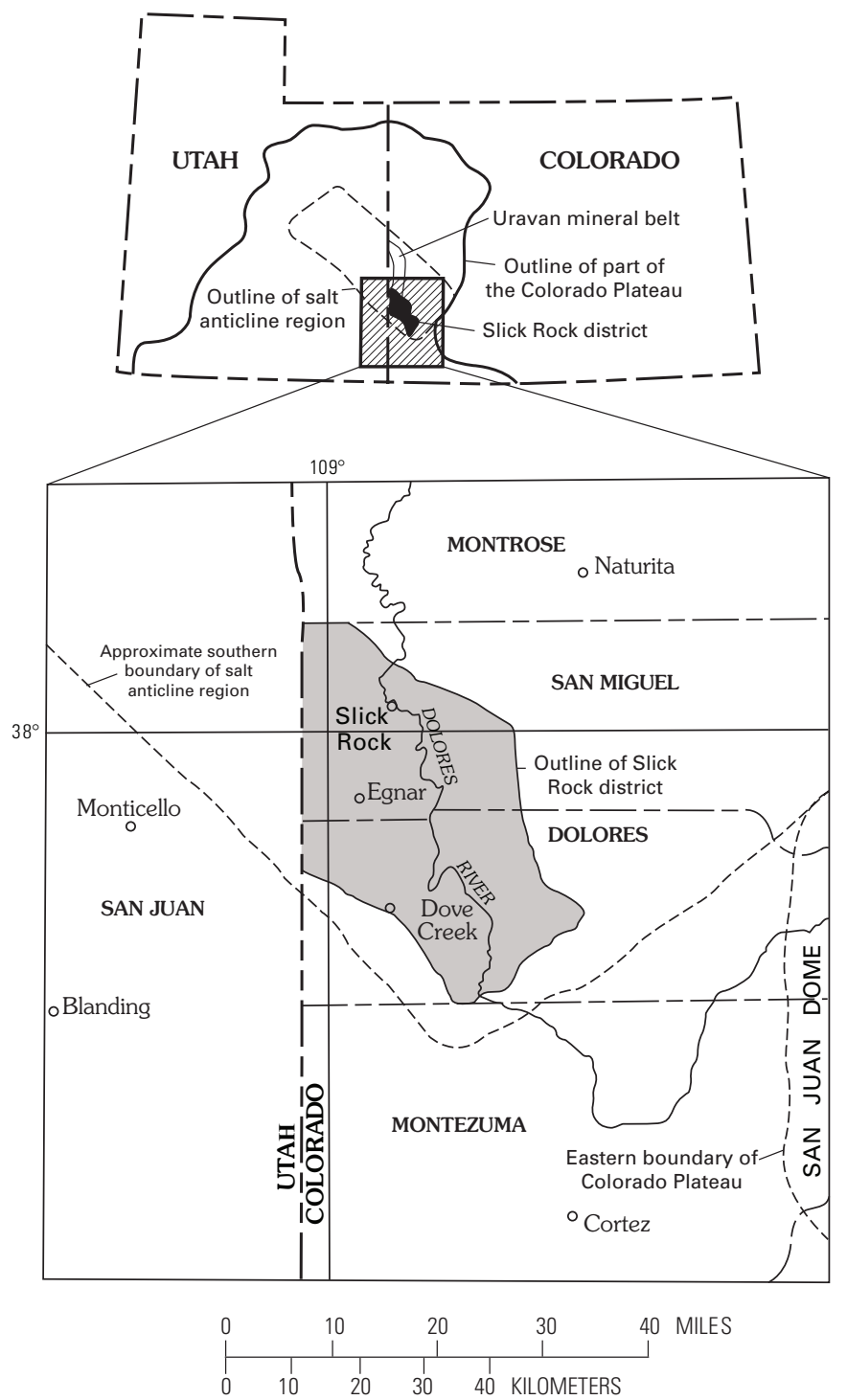

Figure 1. Index map showing location of the Slick Rock district.

them provided access into the Slick Rock district of altering and mineralizing fluids involved in deposition of the uraniumvanadium ore deposits. A few were related to minor deformation in the district in the late Tertiary following ore deposition.

\section{Characteristics of the Host Rocks}

The stratigraphy (lithology, distribution, configuration, and relation to adjacent units), petrography, and geochemical alteration of the principal ore-bearing formations in the district - Chinle Formation of Late Triassic age and Morrison Formation of Late Jurassic age - have been described in detail in previously published reports (Shawe and others, 1968; Shawe, 1968, 1976a). Characteristics of the ore-bearing formations will be reviewed briefly here to provide a framework in which to discuss the distribution, form, mineralogy, and chemical composition of the ore deposits.

\section{Chinle Formation}

The Chinle Formation, although it contains only small known uranium-vanadium deposits in the Slick Rock district, contains very large deposits a few tens of miles to the northwest in the Lisbon Valley district, Utah. Information regarding the lithology and stratigraphy of the formation in the Slick Rock district, of value in possible future exploration of the formation, is given in the following pages.

The Chinle Formation in the Colorado Plateau was deposited on an erosional surface of the Cutler (Lower Permian) and Moenkopi (Lower and Middle(?) Triassic) Formations. The older members of the Chinle (Temple Mountain, Shinarump, Monitor Butte, and Owl Rock) were laid down in what is now western and southern Utah and northern Arizona, and in a general way successively younger members were spread to the northeast, or their deposition was localized to the northeast, so that the younger members are in contact with the underlying Cutler and Moenkopi in that direction (Stewart and others, 1959, figs. 73, 81).

The Chinle Formation consists of a lower part containing variegated bentonitic claystone, clayey siltstone, clayey sandstone, and thin widespread layers of sandstone and conglomerate, and an upper part containing reddish-brown horizontally bedded or structureless siltstone and generally minor amounts of limestone, ripple-laminated siltstone and sandstone, limestone pebble conglomerate, and cross-stratified sandstone, extending throughout most of the Colorado Plateau (Stewart and others, 1972).

In the Slick Rock district (Shawe and others, 1968) several hundred feet of clastic terrestrial red beds comprising the Chinle unconformably overlie the Cutler and Moenkopi Formations. The lowest Chinle strata in the district, the Moss Back Member, consist of 20-75 ft of light greenish-gray calcareous arkosic and quartzose sandstone and gray to greenishgray calcareous sandstone and conglomerate. Small amounts of greenish-gray and even less reddish-brown mudstone, siltstone, and shale are present. The Petrified Forest(?) Member overlying the Moss Back consists of 0-100 ft of greenishgray mudstone, siltstone, and shale, with minor reddish-brown mudstone, and greenish-gray sandstone and conglomerate. The uppermost member of the Chinle, the Church Rock Member, consists of 340-505 ft of reddish-brown siltstone, sandstone, silty sandstone, and mudstone, and locally, thin layers of dark reddish-brown and dark greenish-gray conglomerate. The Wingate Sandstone (Lower Jurassic) disconformably overlies the Chinle in the district.

Sandstone in the Moss Back is light greenish gray, mostly fine grained, and in part clayey, in strata $1-35 \mathrm{ft}$ thick. Conglomerate is greenish gray, contains pebbles mostly of limestone and lesser amounts of quartzite, in strata 1-15 ft thick and commonly near the base of the member. Shale is greenish 


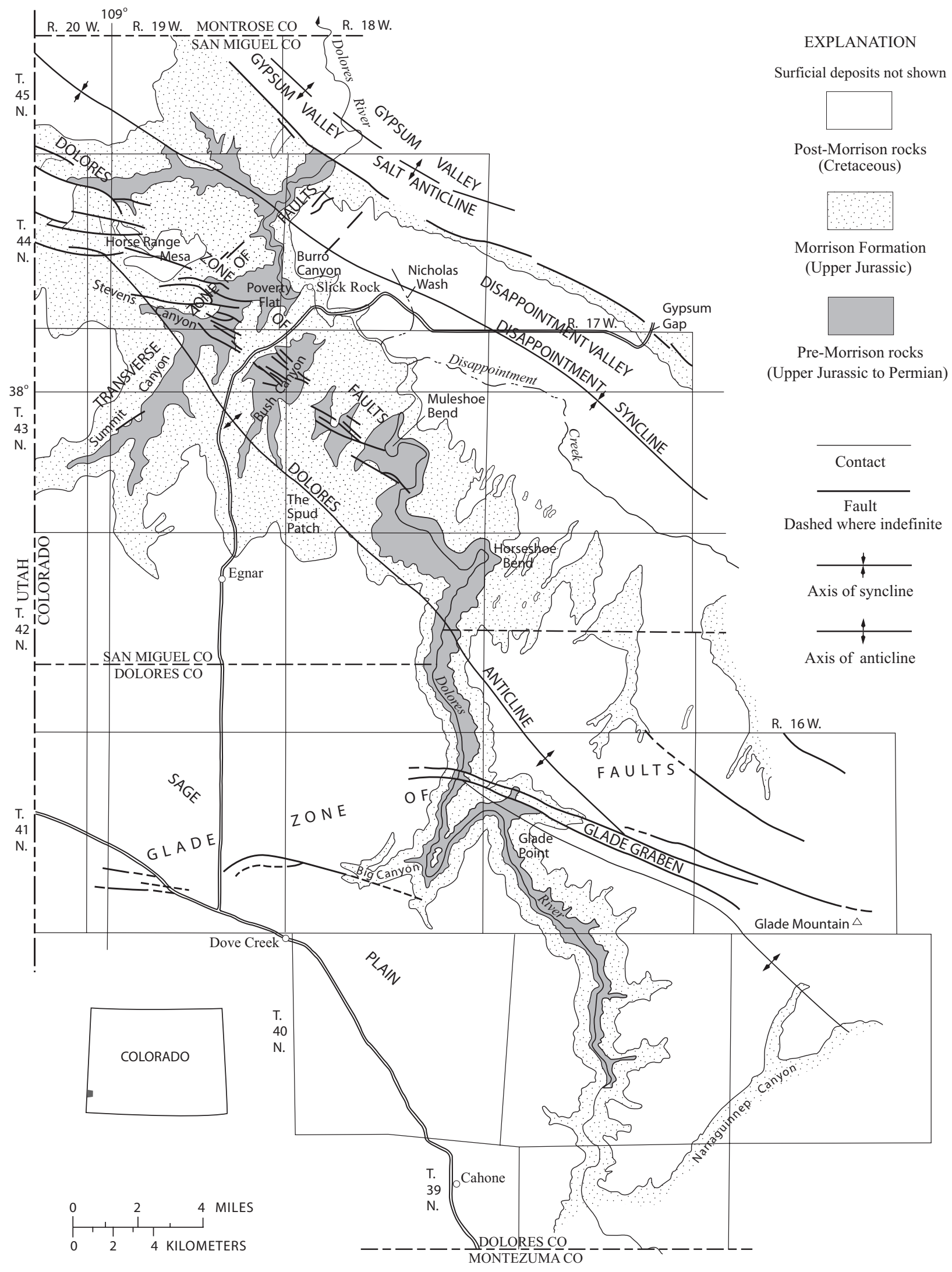

Figure 2. Generalized geologic map of the Slick Rock district. 
gray, in strata $1-5 \mathrm{ft}$ thick. Proportion of sandstone to conglomerate to shale in the member in the district is about 11 to 2 to 1 . These lithologies are interlayered in complex fashion, as lenses of varied size and configuration.

Carbonaceous material is widespread in the member, perhaps most abundant near its base. For example, a one-footthick layer $10 \mathrm{ft}$ above the base of the member in the Dolores River Canyon (Shawe and others, 1968, section F, pl. 4) contains about 10 percent carbonaceous material.

The Moss Back Member covers about 10,000 sq mi in the central part of the Colorado Plateau, and averages about $60 \mathrm{ft}$ thick (Stewart and others, 1972, p. 90, pl. 2). Sediment was deposited in the Moss Back probably mostly by meandering streams, and was derived largely from the Mogollon highland of southern Arizona and southwestern New Mexico, south of the present day Colorado Plateau (Stewart and others, 1972, p. 92). Source rocks were volcanic rocks probably of early Mesozoic age, marine cherty carbonate rocks of Paleozoic age, and gneiss, schist, granite, and metasedimentary rocks of Precambrian age (Stewart and others, 1972, p. 93-94).

The Moss Back Member in the Slick Rock district appears to be made up of a system of coalescing channel-fill deposits which trend northwestward reflecting deposition from streams flowing from the southeast. Thicker parts of the Moss Back represent fill of the deeper channels in this system (Shawe and others, 1968, fig. 13).

The Moss Back Member is the only known host rock for uranium deposits in the Chinle Formation in the district. Greenish-gray sandstone, conglomerate, and mudstone in the member contain abundant carbonized and silicified plant fragments locally; where mineralized rock occurs it is associated invariably with carbonized plant material. The unit also contains fossil reptile bones in places. Cross-beds, current ripple marks, and scour and fill characters are typical of the member and suggest terrestrial stream deposition of most of the unit.

The Moss Back Member was not an object of studies sponsored by the Atomic Energy Commission in the Slick Rock district. However, above-background radioactivity was detected with a scintillation counter in many places at the base of the member in the Dolores River Canyon, mostly within about one mile of the Bullsnake prospect just north of Horseshoe Bend. In this stretch, background radioactivity is about 0.013 milliroentgens per $\mathrm{hr}(\mathrm{mr} / \mathrm{hr})$ and readings as high as $0.028 \mathrm{mr} / \mathrm{hr}$ were measured in conglomerate. Anomalous radioactivity also was detected with a gamma-ray Geiger counter near the base of the member in several drill holes in Summit Canyon put down by Hunt Oil Co. The mineralized zone in the Dolores River Canyon is at an elevation of about $6,000 \mathrm{ft}$, nearly on line with the southeastward projection of the Dolores zone of faults. The mineralized zone in Summit Canyon is at an elevation of about 5,300-5,400 ft within about one mile of the Dolores zone of faults, and on the projection of the southwest-trending fracture zone which crosses the Dolores zone.

\section{Morrison Formation}

\section{Distribution and Configuration of Units}

The Upper Jurassic Morrison Formation is widely distributed in the Western Interior of the United States. In most places it is not subdivided, but on the Colorado Plateau it is divided into several members. The lower part of the Morrison in eastern Utah and western Colorado consists of the Salt Wash Member, whereas in northwestern New Mexico and northeastern Arizona it consists of the Recapture Member (Craig and others, 1955). More recently (for example, Petersen, 1988) the upper part of the underlying Summerville Formation in eastern Utah and western Colorado has been redefined as the Tidwell Member at the base of the Morrison Formation. The Recapture and Salt Wash Members interfinger in the Four Corners area, but no Recapture extends as far north as the Slick Rock district. Three facies of the Salt Wash Member were recognized by Craig and others (1955): a conglomeratic sandstone facies in south-central Utah; a facies of alternating sandstone and mudstone layers northwest, north, and east of the conglomeratic sandstone facies (in which the Slick Rock district lies); and a claystone and lenticular sandstone facies in northeastern Utah and northwestern Colorado. Eastward, the third facies of the Salt Wash merges into claystone and limestone beds of the undifferentiated Morrison Formation at the type locality near Morrison, Colo.

The upper part of the Morrison is divided into the Brushy Basin Member and the Westwater Canyon Member. In the Four Corners area the Westwater Canyon Member underlies the Brushy Basin Member; northward, the Westwater Canyon grades into the Brushy Basin and is absent in the Slick Rock district; southward from the Four Corners area, the Brushy Basin Member apparently was removed by pre-Dakota erosion. The Brushy Basin Member shows a wide range in lithologies, but no consistent variations are evident, and the member has not been divided into regional facies.

The Brushy Basin Member contains materials derived from a westerly source, much of it inboard of the western continental margin, and it contains a high proportion of montmorillonitic clays derived from devitrification of volcanic ash. Greenish-gray and brownish-gray mudstone in the member commonly contain analcite (Shawe, 1968, p. B22, B24) as well as authigenic albite (Shawe, 1968, p. B19-B24), suggestive of alteration by saline water (see also, Turner and Fishman, 1991).

The Salt Wash Member is composed of sedimentary rocks of fluvial origin, deposited in stream channels and on flood plains. The channel-type deposits are lenticular crossbedded sandstones, and the flood-plain deposits are tabular thin- and flat-bedded mudstones and sandstones. Channeltype deposits have greatest aggregate thickness in southeastern Utah, north of Gallup, New Mex., and along the ColoradoUtah boundary midway between Grand Junction and the Four Corners. The direction of sediment transport in the Salt 
Wash, as deduced from measurements of crossbedding, was toward the north, northeast, east, and southeast from present day south-central Utah. Tyler and Ethridge (1985) presented a more detailed evaluation of sediment forms in the Salt Wash Member in the Slick Rock district. The source area of the member, probably what is now southeastern California and west-central Arizona, contributed materials eroded from chiefly clastic rocks, earlier derived from igneous and metamorphic terranes, and carbonate rocks (Craig and others, 1955, p. $150-155)$.

The Morrison Formation is thickest in the vicinity of the Four Corners area, in Disappointment Valley, and along the Colorado-Utah border just south of the Wyoming State line. A cored section of the Morrison Formation near the axis of the Disappointment syncline in the Slick Rock district is more than $1,100 \mathrm{ft}$ thick, the greatest known thickness of the formation. The Slick Rock district is in a region where only the Tidwell, Salt Wash, and Brushy Basin Members of the Morrison Formation are present. In this region, the Morrison Formation stream-type deposits (lenticular crossbedded sandstones) have their greatest aggregate thickness and maximum continuity, based on our studies in the district (Shawe, and others 1968).

The Salt Wash Member in the area of the Paradox Basin, mostly west of the Slick Rock district, was deposited in an area of local downwarping that resulted in a subsidiary fanshaped apron of sediment within the main alluvial plain of Salt Wash deposition (Shawe, 1962). This thicker apron of sediment is characterized by thick and continuous sandstone layers that contain abundant carbonized plant materials. Uraniumvanadium deposits in the district and throughout the Uravan mineral belt are most common in this sediment apron (Shawe, 1962).

\section{Lithology of the Brushy Basin Member}

The lithology of the Brushy Basin Member is described here because of its apparent significance to the origin of the uranium that subsequently accumulated in the ores in the underlying Salt Wash Member. An early report (Waters and Granger, 1953) proposed that the mudstones of the Brushy Basin contained a high content of volcanic materials, that is, devitrified glass that originally contained uranium that was released to formation water upon devitrification. The Brushy Basin, because of its proximity to the Salt Wash, may have been the immediate source of the uranium in the Salt Wash ore deposits. According to Shawe and others, (1968) "The abundance of shard structures in clay, the sharply angular fragments of detrital minerals, and the fairly high plagioclase content of the mudstone leave little doubt that much of the Brushy Basin mudstone (in the Slick Rock district) is of volcanic origin and that it was deposited as ashfalls or in streams or lakes and on flood plains as mixtures of airborne volcanic material and waterborne sediment." Studies that I made (Shawe, 1968) of Brushy Basin rocks in the district indicated that mudstone with clearly defined devitrified shards was not a major part of the member. However, the mudstones also contain abundant montmorillonite (bentonite), which is likely devitrified volcanic ash.

The Brushy Basin Member can be divided conveniently into three parts, not all present throughout the district (Shawe and others, 1968). The three parts are differentiated principally on the basis of their dominant color, either reddish brown or greenish gray. They are referred to as the lower brown unit, middle green unit, and upper brown unit. The lower brown unit, 50-200 ft thick, is composed of mudstone layers which contain, near their base, lenses lithologically similar to sandstone of the Salt Wash Member, and near their top, conglomeratic sandstone lenses. The middle green unit, $0-280$ $\mathrm{ft}$ thick, consists of mudstone layers in which are intercalated lenses of conglomerate and sandstone. The upper brown unit, $120-460 \mathrm{ft}$ thick, is principally mudstone; it contains only minor amounts of sandstone, conglomeratic sandstone, and conglomerate as discontinuous lenses.

The Brushy Basin Member conformably overlies and locally intertongues with the Salt Wash in the vicinity of the settlement of Slick Rock. There it consists of about 400-500 $\mathrm{ft}$ of variegated bentonitic (montmorillonitic) mudstone containing interbedded sandstone and conglomeratic sandstone lenses, more numerous in the lower part than in the upper part of the member (figs. $3 A, 3 B$ ). The mudstone strata are evenly bedded, similar to floodplain-type layers in the Salt Wash Member. Limestone beds and nodules as much as $1 \mathrm{ft}$ thick occur at many levels in the member but appear to be most abundant in the middle part. The Burro Canyon Formation (Lower Cretaceous) conformably overlies the Brushy Basin in the district.

\section{Lithology of the Salt Wash Member}

The Salt Wash Member in the district consists of 275-400 $\mathrm{ft}$ (thinnest along the Dolores anticline and thickest along the Disappointment syncline) of light yellowish-brown (referred to in this report as light-buff) and light-gray to light reddishbrown lenticular fine-grained sandstone layers that show scour-and-fill features and crossbedding of channel-type sediments, intercalated with reddish-brown floodplain-type mudstone layers. The contact of the Salt Wash Member with the underlying Tidwell Member is indefinite, marked in places by intertonguing of sandstone lenses of the Salt Wash with finergrained clastic layers of tidal-flat origin in the Tidwell, and in other places by disconformable channel scours. The Salt Wash Member in the district can be divided roughly into three parts. At the top and bottom of the member, lenses of sandstone coalesce to form generally continuous layers in which are numerous diastems ("splits") of mudstone or claystone. The lower unit ranges from 60-140 ft thick and the upper unit is $40-100 \mathrm{ft}$ thick. The middle part of the member, 100-200 $\mathrm{ft}$ thick, consists dominantly of mudstone which contains scattered, isolated lenses of sandstone. The three parts of the member interfinger and are most evident when viewed from a distance (Shawe and others, 1968, fig. 28). 


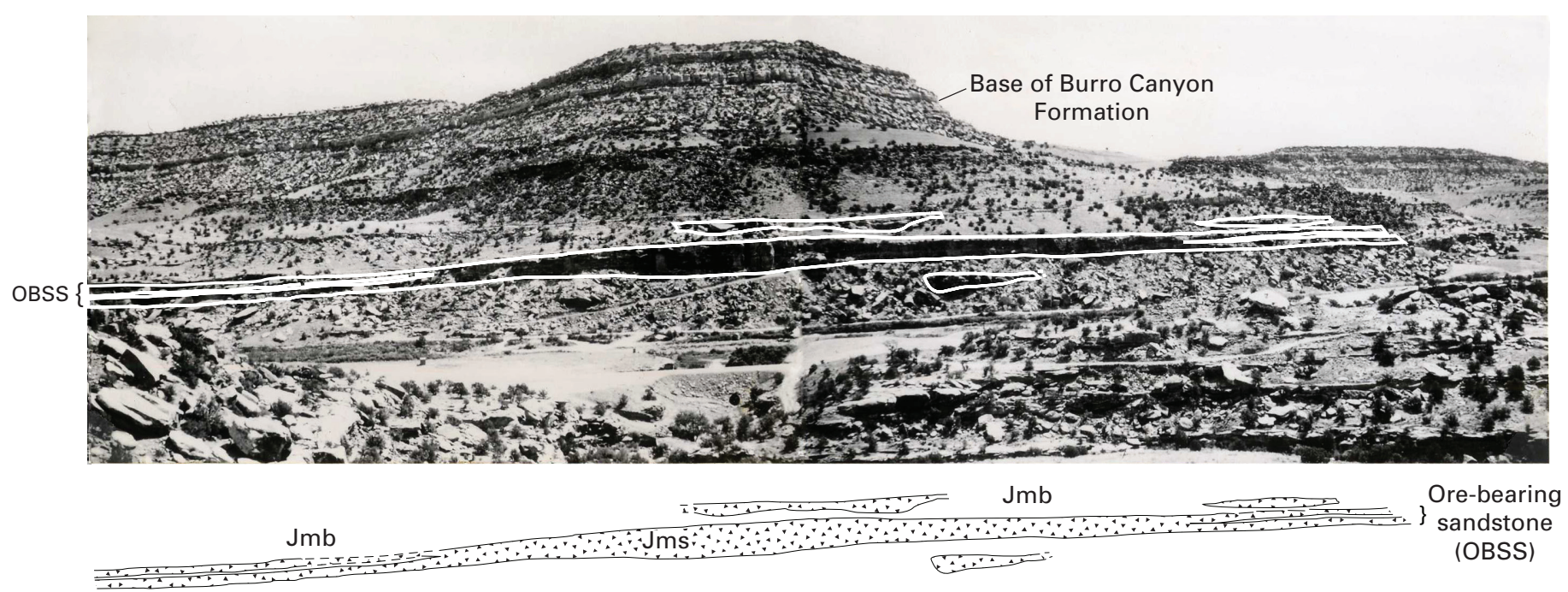

Figure 3A. Photograph of the ore-bearing sandstone of the Salt Wash Member of the Morrison Formation and overlying and underlying strata, showing lateral variations. View east across the Dolores River from near the center of sec. 25, T. 44 N., R. 18 W. Diagram below photograph identifies the ore-bearing sandstone and shows inferred relations between the Salt Wash Member (Jms) and overlying Brushy Basin Member of the Morrison Formation (Jmb); sandstone layers are stippled. Photograph by N.L. Archbold, USGS, circa 1954.

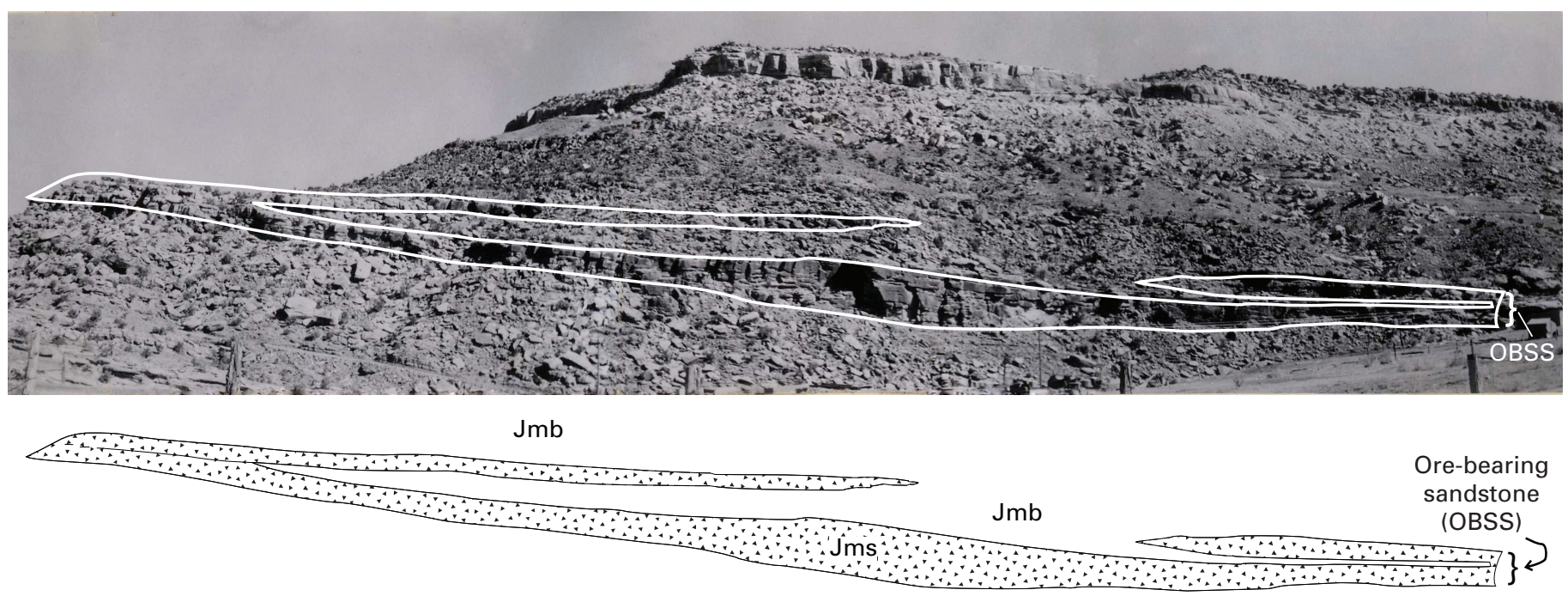

Figure 3B. Photograph of the ore-bearing sandstone of the Salt Wash Member of the Morrison Formation and overlying and underlying strata, showing intertonguing nature of Salt Wash Member and overlying Brushy Basin Member of the Morrison. View north across the Dolores River from near the center of sec. 30, T. 44 N., R. 18 W. Diagram below photograph shows tongues of the ore-bearing sandstone of the Salt Wash (Jms, stippled) pinching out in mudstone of the Brushy Basin (Jmb). Photograph by N.L. Archbold, USGS, circa 1954.

Uranium-vanadium-mineralized sandstone in the Morrison Formation is pale greenish gray, or light buff where weathered, and contains locally abundant carbonized plant fragments; mineralized zones, as in the Moss Back Member of the Chinle Formation, almost invariably are closely associated with local zones of carbonized plant material. Mineralized sandstone units, however, commonly contain extensive zones of rock that contain carbonized plant debris without uraniumvanadium enrichment.

\section{Lithology of the Ore-Bearing Sandstone}

Two exposures of the upper unit or ore-bearing sandstone of the Salt Wash (Jms) are shown in figures $3 A$ and $3 B$. Measured sections that illustrate lateral variations in the upper unit are given in Shawe and others (1968, p. A68). Four additional measured sections of the ore-bearing sandstone are presented here. They provide additional details of lithology to show local complexities of the Salt Wash Member, which 
as elaborated later help understand the considerable variation in ore body forms. Also, specific features of these sections will be referred to in later pages.

Lithologic log by D.R. Shawe of part of diamond drill hole DV-93, near the mouth of Joe Davis Canyon, NW1/4, SW1/4, sec. 33, T. 44 N., R. 18 W. (see pl. 2 for location):

\section{Lower unit of Brushy Basin Member (incomplete):}

11. Mudstone, siltstone, and sandstone, interbedded, reddish brown, light brownish gray, and light greenish gray; sandstone contains abundant greenish-gray and reddish-brown interstitial clay and clay flakes and pebbles; sparse biotite, tourmaline, and black opaque minerals; all rock types contain sparse to abundant calcite, most light-colored intervals have abundant calcite.

10. Mudstone, light greenish-gray

Total incomplete Brushy Basin Member

\section{Upper unit of Salt Wash Member:}

9. Sandstone, light gray, fine to very fine grained, medium grained in 1-ft layer $7 \mathrm{ft}$ above base; sparse black opaque minerals and barite; abundant interstitial greenish-gray clay in upper $2 \mathrm{ft}, 1$ - $\mathrm{ft}$ layer $7 \mathrm{ft}$ below top, and 1-ft layer $7 \mathrm{ft}$ above base; sparse films of greenishgray clay in 1-ft layer $7 \mathrm{ft}$ above base; generally sparse calcite; abundant calcite just above upper clayey layer, just above and below lower clayey layer, and in lower $3 \mathrm{ft}$ of sandstone; sparse carbonaceous material in clay films

8. Mudstone, gray.

7. Sandstone, light gray, fine grained; sparse black opaque minerals, tourmaline, red and gray interstitial clay and clay seams, greenish-gray clay pebbles and seams in layer $0.1 \mathrm{ft}$ thick near base; abundant carbonaceous material in sparse clay films.....

6. Sandstone and mudstone, interbedded, gray to black, fine grained; sparse calcite; abundant dark-greenish-gray interstitial clay and clay pebbles; very abundant carbonaceous material. Dark-gray high-grade uranium-vanadium mineralized rock

5. Sandstone, light gray, fine grained; very abundant calcite; abundant dark-gray interstitial clay and clay seams and films; sparse carbonaceous material

4. Sandstone, gray, fine grained; sparse calcite, abundant in lower $0.3 \mathrm{ft}$; abundant darkgray interstitial clay and clay seams and films; abundant carbonaceous material. Gray low-grade uranium-vanadium mineralized rock

3. Sandstone, light gray, fine grained; sparse black opaque minerals, barite; moderate to abundant calcite, abundant in 2-ft layer $1 \mathrm{ft}$ below top and in lower $2 \mathrm{ft}$; sparse interstitial white clay; moderate carbonaceous material as films.

Total upper unit

Middle unit of Salt Wash Member (incomplete):

2. Mudstone, light greenish gray; sparse to moderate calcite; sparse carbonaceous material

1. Mudstone, light reddish brown and light brownish gray to light greenish gray, interbedded; sparse to very abundant calcite; sparse biotite.

Total incomplete middle unit 
Lithologic log by D.R. Shawe of part of diamond drill hole DV-112A, Disappointment Valley, SE1/4, SW1/4, sec. 27, T. 44 N., R. 18 W. (see pl. 2 for location):

Lower unit of Brushy Basin Member (incomplete):

Thickness (ft)

10. Mudstone and siltstone, interbedded, reddish brown and light greenish gray; abundant calcite, sandy in places

Total incomplete lower unit

\section{Upper unit of Salt Wash Member:}

9. Sandstone, light greenish gray, fine grained; abundant calcite in upper part, sparse in lower part; very abundant interstitial greenish-gray clay; grades into sandstone below

8. Sandstone, light gray, fine grained; sparse dark minerals and chert; abundant calcite in upper $1 \mathrm{ft}$, sparse below; sparse greenish-gray interstitial clay and clay pebbles; sparse carbonaceous flakes and films.

7. Sandstone, gray, fine grained; sparse dark minerals and chert; sparse calcite; sparse to abundant greenish-gray interstitial clay and clay pebbles; sparse carbonaceous material as flakes and films; weakly mineralized.

6. Sandstone, light gray and dark gray, interbedded, fine grained; sparse dark minerals and chert; sparse to abundant calcite, abundant in thin layers near top, middle, and at base; sparse to abundant gray interstitial clay, clay films, and clay pebbles; abundant carbonaceous material as films, flakes, and larger fragments; low- and high-grade uranium-vanadium mineralized rock

5. Sandstone, light gray, fine grained; sparse dark minerals and calcite; sparse carbonaceous films.

4. Sandstone, gray, fine grained; abundant calcite in upper half, moderate in lower half; sparse to abundant flakes and pebbles of light-greenish-gray clay; abundant carbonaceous flakes and films; weakly mineralized

3. Sandstone, light gray, fine grained; sparse dark minerals and chert; sparse pyrite with carbonaceous material $6 \mathrm{ft}$ above base; generally sparse to moderate calcite, abundant at top and base; sparse seams and pebbles of greenish-gray clay; sparse to abundant carbonaceous material, abundant as flakes and films in 3-ft layer $19 \mathrm{ft}$ above base, 0.2 -ft layer $6 \mathrm{ft}$ above base, and 1-ft layer $2 \mathrm{ft}$ above base; a dark-gray siltstone layer $0.5 \mathrm{ft}$ thick with abundant carbonaceous material lies $18 \mathrm{ft}$ above base

Total upper unit

\section{Middle unit of Salt Wash Member (incomplete):}

2. Mudstone, light greenish gray; contains 65 percent mudstone and clay pebbles and seams in fine-grained light-gray sandstone, in upper $1 \mathrm{ft}$; sparse to abundant calcite, abundant in thin layers in middle and lower part; sparse carbonaceous material

1. Mudstone, siltstone, and sandstone, interbedded, reddish brown, light greenish gray, and light reddish brown; sparse to abundant calcite; sandstone is light reddish brown, fine grained, contains sparse black opaque minerals

Total incomplete middle unit. 
Lithologic log by O.T. Marsh, E.L. Boudette, and G.C. Simmons of part of diamond drill hole DV-52, just southwest of Gypsum Gap, SE1/4, NW1/4, sec. 2, T. 43 N., R. 17 W. (southeasternmost drill hole shown on sheet 2 of Rogers and Shawe, 1962)):

Lower unit of Brushy Basin Member (incomplete):

Thickness (ft)

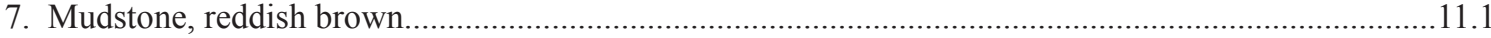

Total incomplete lower unit..............................................................................................11.1

Upper unit of Salt Wash Member:

6. Sandstone, gray, fine grained; sparse dark minerals; sparse gray clay pebbles; trace of

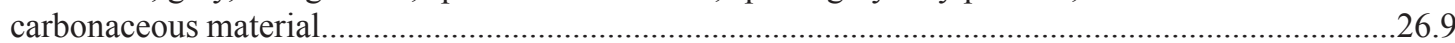

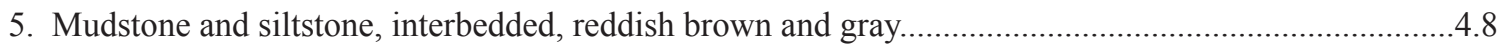

4. Sandstone, gray, fine grained; sparse dark minerals; trace of carbonaceous material.............................16.6

3. Sandstone, gray, fine grained; sparse dark minerals, sparse carbonaceous material................................6.5

Total upper unit

Middle unit of Salt Wash Member (incomplete):

2. Mudstone, greenish gray; abundant calcite...

1. Mudstone and siltstone, interbedded, red and greenish gray, mottled ……..........................................

Total incomplete middle unit.

Lithologic log by W.B. Rogers of part of diamond drill hole DV-116, Disappointment Valley, NE1/4 NW1/4 sec. 27, T. 44 N., R. 18 W. (see pl. 2 for location):

\section{Lower unit of Brushy Basin Member (incomplete)}

5. Mudstone and siltstone, interbedded, reddish brown; abundant calcite; 10 percent of interval has sparse calcite

Total incomplete lower unit

\section{Upper unit of Salt Wash Member:}

4. Sandstone, light reddish brown, medium fine and fine grained; sparse altered feldspars; sparse to abundant calcite, moderate in upper $1.5 \mathrm{ft}$, abundant in lower $2 \mathrm{ft} ; 15$ percent reddish-brown interstitial clay; trace of carbonaceous material

3. Sandstone, reddish brown, fine grained; trace of barite; abundant calcite in upper $1 \mathrm{ft}$, moderate calcite below; 50 percent reddish-brown interstitial clay; trace of carbonaceous material.

2. Sandstone, light reddish brown, fine and medium grained; sparse barite and chert; sparse to abundant calcite, abundant in upper $6 \mathrm{ft}$, in layers $0.5 \mathrm{ft}$ thick 7 and $9 \mathrm{ft}$ below top, $4 \mathrm{ft}$ thick $14 \mathrm{ft}$ below top, and in lower $12 \mathrm{ft}$; 5 percent reddish-brown interstitial clay and clay seams

Total upper unit.

Middle unit of Salt Wash Member (incomplete):

1. Mudstone and siltstone, interbedded reddish brown; abundant calcite, 10 percent of interval has sparse calcite; siltstone is in part gray, siliceous.

Total incomplete middle unit 


\section{Relation of Uranium-Vanadium Deposits to Carbonaceous Material}

Uranium-vanadium deposits in the Slick Rock district are found near local accumulations of abundant detrital carbonaceous material. As discussed in detail in a later section of this report, the association was the result of the influence of organic material on composition of formation water which caused precipitation of the ores. Some concentrations of organic material, largely carbonized plant remains, are mineralized, whereas others are not; locally ore bodies near carbonized plant fragments contain no visible carbonaceous material. Coalified and charcoal-like plant fragments are abundant in places and widely distributed in the upper unit of the Salt Wash Member. They tend to occur in isolated and irregular areas, some a mile or more in extent, throughout the district. Massive organic material, asphaltic in character and not described previously in Slick Rock ore deposits, occurs in some unweathered ore bodies. The material was probably originally in the form of humates or humate gels derived from carbonized plant materials (see Hansley and Spirakis, 1992, for a discussion of the development of humates from organic plant materials).

Some fossil logs have been replaced completely by either carbonate minerals or silica; a silicified log imbedded in sandstone near the Cougar mine is shown in figure 4. Minor amounts of carbonized saurian bones occur in sandstone (fig. 5); however, although in places mineralized, they are not common.

Plate 2 shows the lateral distribution and abundance of carbonaceous material in the ore-bearing sandstone in an area of several square miles in the western part of Disappointment

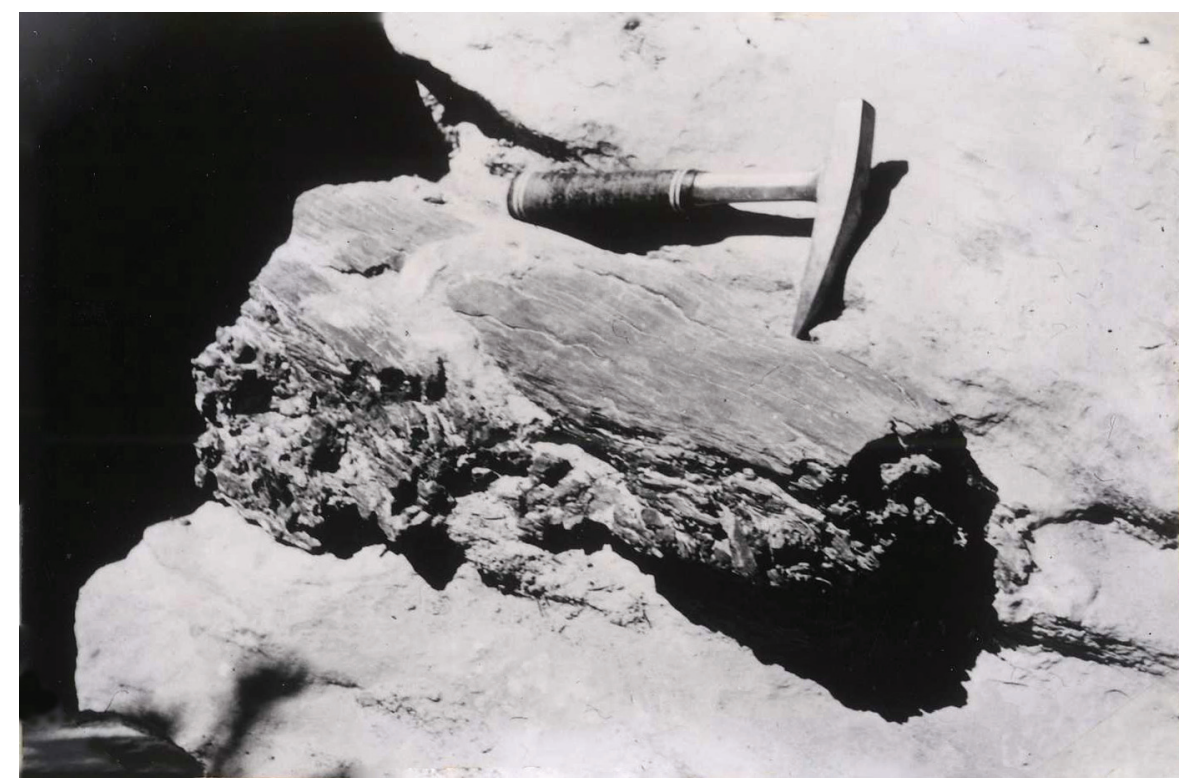

Figure 4. Silicified log imbedded in the orebearing sandstone near the Cougar mine, Lower group of mines.

Figure 5. Carbonized, silicified, and uranium-vanadium mineralized dinosaur bones, identified by leader, imbedded in sandstone of the Morrison Formation in the Cougar mine.

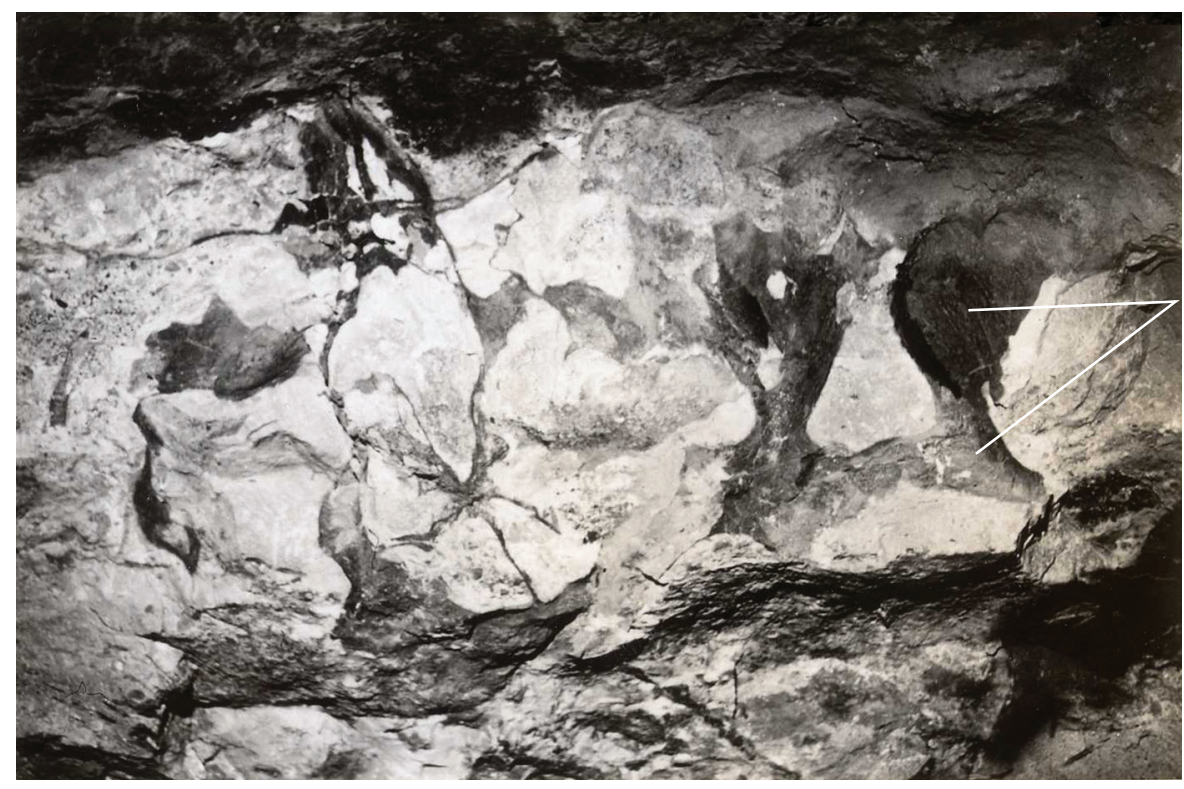

Dinosaur bone 
Valley, as determined from diamond-drill cores. Relative amounts of carbonaceous material indicated are estimates of average contents based on the generally irregular vertical distribution throughout each logged drill hole (for example, pl. 3, and logs of diamond-drill holes given in the previous section, p. 11-13).

A cross section (pl. 3, $A-A^{\prime}$ on pl. 2) based on one line of diamond-drill core logs shows the stratigraphic distribution of carbonaceous material in the ore-bearing sandstone and adjacent strata in the Disappointment Valley area. The cross section indicates that visible carbonaceous material may be distributed through the entire thickness of the ore-bearing sandstone, it may be irregularly distributed, or it may be virtually absent. The cross section also shows a tendency for carbonaceous material to be more abundant in the lower part of the unit. The thickness of greenish-gray mudstone layers adjacent to the ore-bearing sandstone depended on the reducing effect of carbonaceous material in the sandstone; thicker greenish-gray mudstone layers tend to be associated with greater abundance of carbonaceous material (pl. 2).

Carbonaceous material in strata above and below the ore-bearing sandstone seems to be distributed randomly, and it is mostly less abundant than in the ore-bearing sandstone (logs of diamond-drill holes given in previous section; pl. 3). Although the uranium-vanadium deposits (both tabular and roll) are associated with carbonaceous material, they also tend to occupy a particular sub-horizontal layer in the ore-bearing sandstone independent of the detailed distribution of carbonaceous material as shown in plate 3 . It should be noted that ore-grade mineralized drill holes in the Disappointment Valley area (pl. 2) are most abundant in the north part of the drilled area; this concentration of mineralized ground is along an ore trend, controlled by sedimentary features, extending from

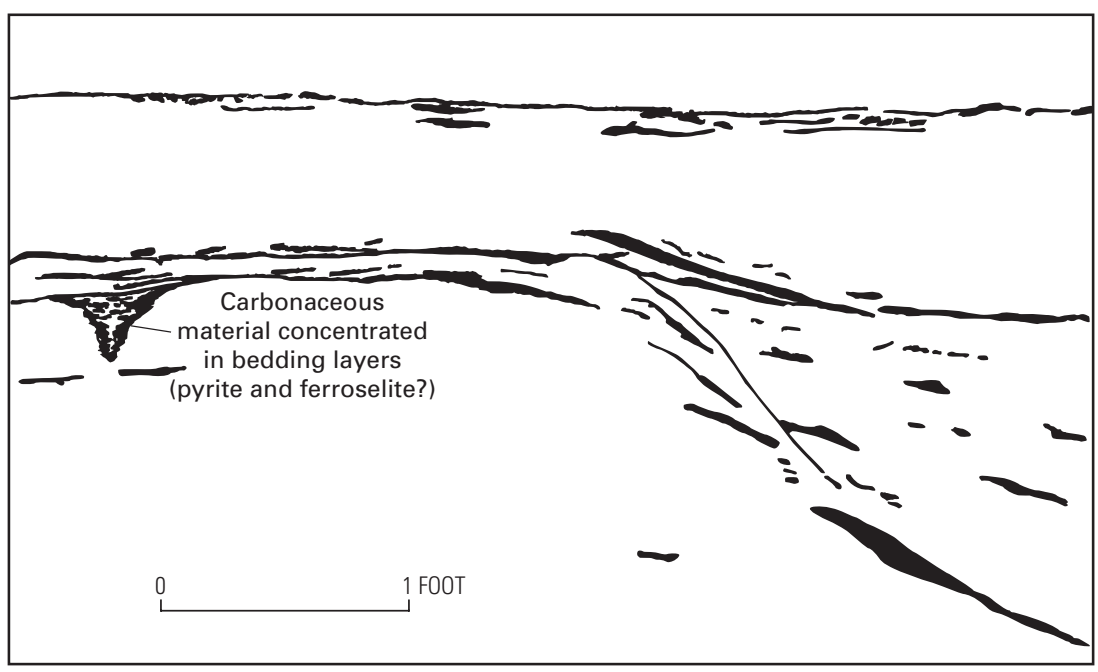

Figure 6. Cross-sectional sketch of part of the ore-bearing sandstone in the King No. 4 mine, Legin group of mines, showing carbonaceous material (black) concentrated in bedding layers. Carbonaceous material is carbonized plant fragments, coaly in places. Lower seam of carbonaceous material in left center contains abundant pyrite and ferroselite(?). the Cougar mine (Lower group of claims) to the northwest, southeastward through the Georgetown group of deposits, the Burro group of deposits, and into the northern Disappointment Valley area.

Cross sections (not illustrated in this report) through lines of diamond-drill holes subparallel to and west of section $A-A^{\prime}$ shown in plate 3 , indicate relations between lithologies and mineralized zones more complex than those illustrated in plate 2. These cross sections (available in archives in the USGS library in Bldg. 20, Denver Federal Center) show the relation of sporadic mudstone layers and positions of uranium- and vanadium-mineralized layers.

Carbonized fragments of plants range in size from minute flakes to large tree trunks $3 \mathrm{ft}$ in diameter and several tens of feet in length. Carbonized fossil logs mostly lie parallel to current directions indicated by current lineations in sandstone (see pl. 4; also Shawe and others, 1968, pl. 9), and at the tops of sandstone layers just beneath claystone and mudstone layers. Locally, mudstone particles and carbonaceous material are concentrated in pockets in sandstone, commonly referred to as "trashy" zones. Figures 6 and 7 show details of the distribution of some carbonaceous material in the ore-bearing sandstone.

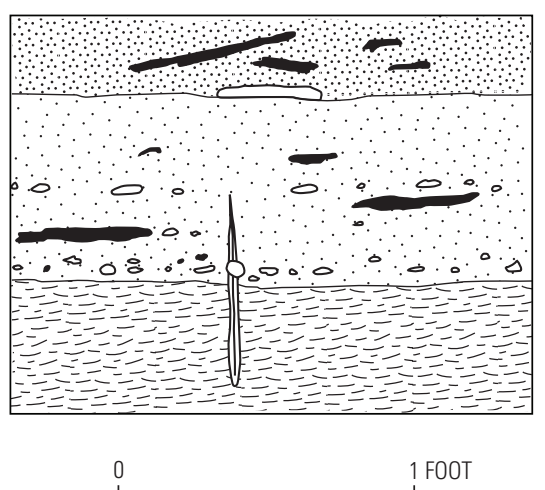

Figure 7. Cross-sectional sketch of part of the ore-bearing sandstone (increased density of stippling indicates finer grain size) and underlying greenish-gray mudstone (dashed) in the Cougar mine, Lower group of mines, showing carbonaceous material (solid black), claystone pebbles (open outlines), and limestone nodule (open outline) at base of upper sandstone bed. Note thin vertical fracture passing upward from mudstone into sandstone but not breaking a claystone pebble beyond which it projects. The fracture is lined with chalcocite surrounded by a narrow halo of copper carbonate and ferric oxide minerals. 
Thin veinlets of carbonaceous material (resembling asphaltite) in the Strawberry Roan mine are as much as 1 in. wide and 10-12 ft long (locations of mines cited in the text are shown on pl. 1, Shawe, 1968, or given in Appendix A, keyed to mining groups shown on pl. 1, this report). The veinlets cut sharply across sandstone bedding. These veins have not been observed in outcrops. Similar material has been found in fossil logs in the Sarah Ellen mine, suggesting that the veinlets are derived from woody rather than petroliferous sources. They may have formed as the result of solidification of humate gels derived from the organic material and localized in fractures that formed following lithifaction. Unfortunately their composition has not been studied adequately.

\section{Uranium-Vanadium Ore Deposits}

The following pages give details of the relation between weathered and unweathered deposits, distribution of the deposits, relation to altered rocks, localization controls, forms of the deposits, textural variations, mineral and chemical compositions, isotopic compositions of some elements of the deposits, and their implications to origin and formation (genesis) of the deposits.

Associated with the ore minerals are others precipitated along with them as part of the process of mineralization, such as sulfides and other authigenic minerals. Deposits near or at the surface that have been exposed to recent weathering contain numerous secondary (supergene) minerals formed by oxidation of primary (hypogene) minerals. Ore mineralogy generally is incidental to mining, except as visible indication of ore, but some minerals determine the methods of separation of the valued elements from the ore, a topic not dealt with in this report. Many of these minerals, however, contribute to understanding the genesis of the deposits, as elaborated in later pages.

Mineralized rock is arbitrarily subdivided as weakly mineralized, strongly mineralized, or ore. Because uranium was the principal element sought in the Slick Rock ores during the latest period of mining, it determined the classification. At the time of our studies in the district (1953-58), rock containing uranium up to 0.01 weight percent was classified by the USGS as weakly mineralized, that with $>0.01$ weight percent and up to 0.1 weight percent was classified as strongly mineralized, and that with $>0.1$ weight percent uranium was classified as ore. Because analyses of mineralized rocks were reported as either percent $\mathrm{U}$ or percent $\mathrm{U}_{3} \mathrm{O}_{8}$ content, they are similarly recorded in this report. Experience has shown that distinction between mineralized and unmineralized rock, based on numerous chemical determinations of the uranium and vanadium content of rocks, can be made by visual recognition of uranium and vanadium minerals. A further distinction of the term mineralized is made in a later section (p. 47).

\section{Weathered and Unweathered Deposits}

Uranium-vanadium ore deposits in the Slick Rock district consist both of "oxidized" or weathered deposits that are above the present water table near the surface (characterized by high-valent uranium and vanadium minerals), and of "unoxidized" or unweathered deposits that are below the water table and relatively deeply buried (characterized by low-valent uranium and vanadium minerals). Aside from some differences in mineralogy, most characteristics of ore bodies of the two types of deposits, particularly their forms, are quite similar. In places, a weathered deposit near the surface grades into less weathered ore farther below the surface, and in such places the essential identity of most aspects of the weathered and less weathered ores is evident. An excellent example is illustrated in plate 4, a map and cross sections of the Strawberry Roan deposit, where carnotite-type ore near the surface grades at greater depth below the surface into much less oxidized corvusite-type ore. Along with changes in mineralogy which accompanied oxidation of deposits, some movement of chemical components probably occurred, although such changes are not well known and may have been minor; study under the microscope of oxidized mineralized samples suggest little movement of components (see later discussion, p. 39). Certain details of the ores, established from study of oxidized deposits, thus have been extrapolated to unoxidized ores of similar form and composition and are used in interpretation of ore controls and genesis of the deposits.

At the time of our studies in the district (1953-1958), ore deposits accessible for mapping and detailed study were mostly near-surface and oxidized, although some studies were made in deeper less-oxidized and unoxidized deposits. Studies of mineralized and adjacent altered rocks obtained from unoxidized cores of deep drill holes will be described in the section on relation of the deposits to altered rocks (p. 17-19).

\section{Distribution of Uranium-Vanadium Deposits}

Uranium-vanadium deposits are distributed widely in the Morrison Formation throughout the Slick Rock district. In addition to the deposits in the upper unit or ore-bearing sandstone of the Salt Wash Member, a few deposits are found in sandstone layers in the lower part of the overlying Brushy Basin Member. Minor mineralized zones are known in the Moss Back Member of the Chinle Formation.

Most of the known Salt Wash deposits are in the north part of the district in a belt called the Dolores ore zone, centered on a northwest-trending Dolores zone of faults and widest where a northeasterly set of faults crosses the Dolores zone (fig. 2). The ore zone is about $20 \mathrm{mi}$ long, more than 10 mi wide near the intersection of the fault sets, and narrows southeastward to about $2 \mathrm{mi}$ wide. It lies within and normal to the Uravan mineral belt near the south end of the belt as defined by Fisher and Hilpert (1952). The Salt Wash deposits west of Egnar are centered along the southwestward projection of an inferred transverse fault structure underlying the parallel surface faults. Some deposits lie in a narrow zone along the faults bordering the northeast edge of the district (see pl. 1) along Gypsum Valley. A few Salt Wash deposits are located along the Dolores River Canyon east of Dove 
Creek. Uranium-vanadium deposits in the lower part of the Brushy Basin Member are chiefly in a small area a few miles southeast of the town of Slick Rock. Mined ore deposits and areas are shown on a map of the north part of the Slick Rock district (pl. 1), and on a geologic map of the district (Shawe and others, 1968, pl. 1). Principal producing areas (SM-1 to 5) of the district (pl. 1) are roughly grouped along the inferred northeast-southwest transverse fault structure.

Subparallel northeast-southwest-oriented surface faults, shown on figure 2, suggest a deeper through-going structure. Although the surface faults show no evidence of having controlled mineralization (Shawe, 1970), they may be a late (post-alteration) reactivation of a deeper and older structure that earlier had channeled mineralizing fluid.

Within the ore zone several ore "trends" or elongate clusters of ore bodies (pl. 1, Shawe and others, 1968) are thought to reflect their distribution within major stream channel systems. One notable ore trend extends southeastward from the Lower group of deposits (including the Cougar mine) north of Slick Rock, across the gap of the Dolores River Canyon, through the Georgetown group to the Burro group of deposits on the north side of Burro Canyon, and probably beyond to unmined mineralized zones underlying Disappointment Valley (fig. 2). The major stream channel systems in the ore-bearing sandstone are zones of coalescing elongate sandstone lenses in which current lineations are subparallel to the trend of the sandstone lenses. These systems form the thicker parts of the host sandstone layers whose maximum permeability parallels the elongate sandstone lenses.

Within the major stream channel systems, the deposits occur in seemingly random distribution. Certain locations within the host sandstone layers are preferred, however, where sandstone permeability and (or) flat impermeable mudstone seams influenced position and form of the deposits. Plate 5, a derivative map of the Cougar mine area in the Lower group of mines, shows a part of a braided-stream system of sandstone lenses that localized the ore bodies.

The ore deposit at the Cougar mine consists of interconnecting ore bodieswhich lie in an originally subhorizontal zone at and near the base of the ore-bearing sandstone. Initial sandstone deposition was by generally northeast-flowing streams, upon a somewhat uneven surface of underlying mudstone (pl. 5; Shawe and others, 1968, fig. 31). Subsequently a braided system of southeast flowing streams cut into the initial sandstone layer and deposited additional sand lenses. In places this system scoured completely through the earlier sand layer, and elsewhere remnants of the earlier layer remained beneath the southeast-trending channels. Interfluves consisting of the earlier system remained between strands of the later system. Subsequently these sand layers were buried beneath a layer deposited by streams again flowing predominately northeastward.

Despite locally irregular distribution of carbonaceous material or of thin, irregular, and discontinuous mudstone layers or lenses within the sandstone lenses, the uraniumvanadium deposits tend to occur at a particular subhorizontal horizon within the larger host sandstone lenses (plate 3), probably influenced by density variation of fluids involved. But also, local concentrations or fragments of carbonaceous material within the subhorizontal horizons have influenced positions of mineral deposition, as did impermeable mudstone layers within the sandstone. The example shown in plate 3 illustrates uranium-vanadium localization just above the middle of the sandstone lens. Localization also is common near the base of the ore-bearing sandstone, as at the Norma Jean No. 2 mine and the Belmont claim, Spud Patch group of mines (pl. 6), as well as the Cougar mine. An example of ore localization near the base of the host ore-bearing sandstone at the Cougar mine is illustrated in figure 8. Roll ore deposits (described in detail in later pages) formed in sandstone above a basal channel scour. In a few places, carbonized logs, largely replaced by calcite, localized minor roll ore bodies. In order to show the extremely varied effect of local lithologic (sedimentation) character upon ore deposition, other ore deposits near the base of sandstone layers will be described in detail in later sections.

Deposits occur commonly within sandstone near the edges of broad (several hundred feet), thin (less than $10 \mathrm{ft}$ ) impermeable mudstone layers or lenses within sandstone (for example, Shawe and others, 1968, pl. 8). At the Little Max and Sunday mines, Spud Patch group of mines (pl. 7), irregular tabular and associated roll deposits are localized in and near a zone of irregular and discontinuous mudstone layers and lenses within the lower part of the ore-bearing sandstone.

\section{Alteration of Sedimentary Rocks Related to Uranium-Vanadium Ore Deposits}

The genetic relation of alteration processes to the concentration and deposition of the ores is indicated by the following review of the mineral assemblages of altered rocks in the Slick Rock district described in earlier reports (Bowers and Shawe, 1961; Shawe, 1956b, 1976a; Breit and others, 1990; Breit and Goldhaber, 1995), and by some additional information.

The relation of mineral alteration to the uranium-vanadium ore deposits involves three types of sandstone in the ore-bearing sedimentary units. Heavy-mineral distributions in and adjacent to the ore-bearing sandstone, as determined by studies of samples from diamond-drill core from the Disappointment Valley area (see pl. 2 for the area tested by the drill holes, and Bowers and Shawe, 1961, for a summary of some of the data), quantified variations that defined three sandstone facies. These were defined as red-beds-facies sandstone and carbon-facies sandstone, both syngenetic (diagenetic) alterations, and altered-facies sandstone, an epigenetic alteration (Bowers and Shawe, 1961; Shawe, 1976a).

Red-beds-facies sandstone is colored reddish brown by contained hematite (as a stain on detrital grains) and it contains relatively abundant detrital black opaque minerals (magnetite and ilmenite, probably largely altered to hematite) and no pyrite. These black opaque minerals contain, in addition 


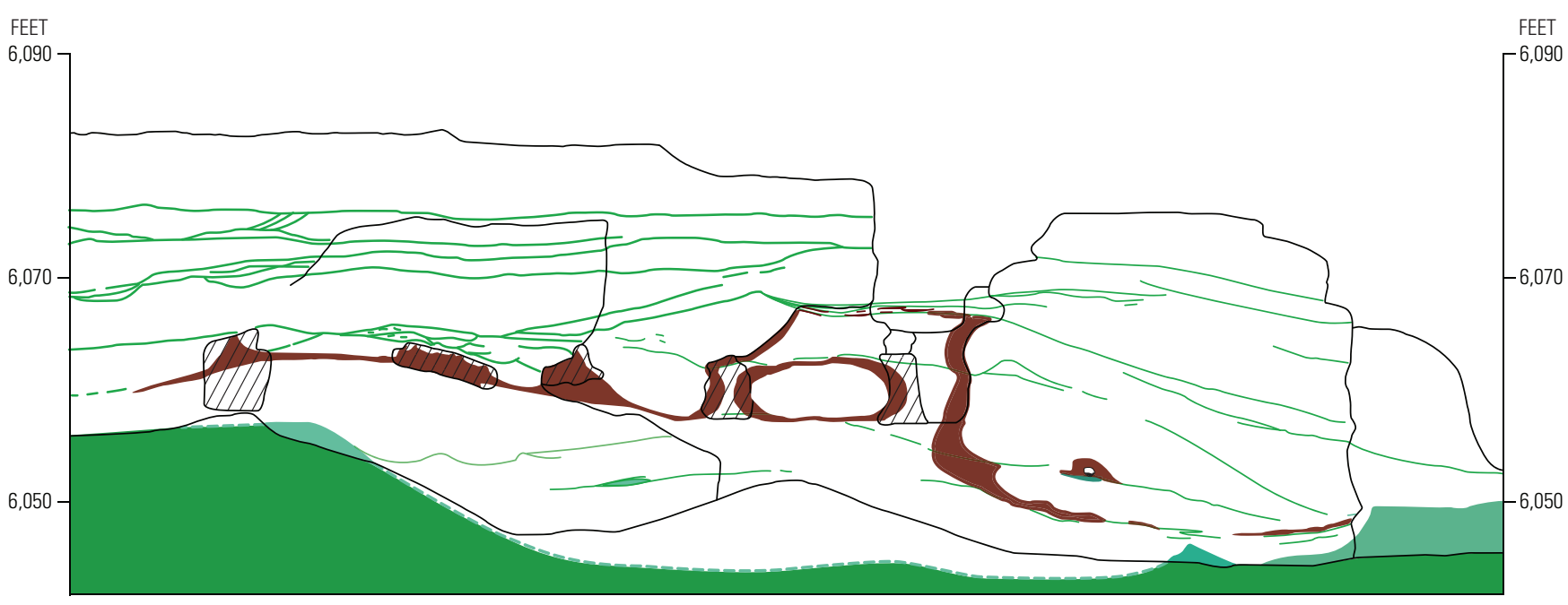

EXPLANATION

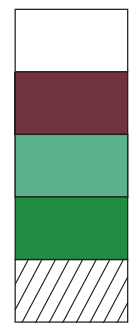

Sandstone

Ore sandstone

Greenish-gray mudstone

Mudstone projected beneath

surface

Mine opening

Figure 8. Cross-sectional sketch of the uranium-vanadium ore-bearing sandstone drawn from a rim exposure in the Cougar mine area, showing roll ore bodies localized above a basal channel scour. Location of the diagram is shown in Shawe and others (1968, pl. 9 and fig. 31). Red is uranium-vanadium mineralized rock, green is mudstone that underlies ore-bearing sandstone and also forms irregular thin layers within ore-bearing sandstone. Mineralized sandstone surrounds a carbonaceous log (small open oval) partly replaced by calcite, lower right. Cross-hatched areas are mine workings. No vertical exaggeration.

to major iron and titanium, significant amounts of chromium and vanadium (Shawe, 1976a). Silica cement occurs in some rocks; calcite cement is widespread and occurs mostly as interstitial patches less than $0.5 \mathrm{~mm}$ across; and minor barite forms local interstitial patches. Red-beds-facies sandstone is abundant and widespread in the district. None of the Slick Rock uranium-vanadium deposits occur in red-beds-facies sandstone, although red beds may occur locally within a few meters of the deposits.

Carbon-facies sandstone was defined initially (Bowers and Shawe, 1961) almost entirely on the basis of detrital black opaque heavy mineral content. These rocks, which have no hematite coloring, are light gray or light greenish gray, buff (light brown) or light yellowish brown (light buff). The buff or light-yellowish-brown color is due to hydrated iron oxide formed from oxidized pyrite in weathered rock. Carbonfacies rocks contain only a moderate amount of detrital black opaque minerals and a small amount of pyrite. Contents of silica, calcite, and barite are generally similar to those in the red-beds-facies sandstone. In the Chinle Formation carbonfacies sandstone occurs in the Moss Back Member; in the Morrison Formation carbon-facies sandstone is found mostly in the upper part (ore-bearing sandstone) of the Salt Wash Member. Carbon-facies sandstone is much less voluminous and widespread than is the red-beds-facies sandstone. Carbonfacies sandstone may or may not contain ore deposits. Locally in carbon-facies, black opaque mineral destruction may have been sufficient to give the sandstone a composition similar to altered-facies sandstone.

Altered-facies sandstone, like carbon-facies sandstone, lacks hematite coloring and is light gray or greenish gray, and as initially defined (Bowers and Shawe, 1961), it contains only sparse detrital black opaque minerals, it contains minor amounts of pyrite, and it may or may not contain carbonaceous material. Uranium-vanadium deposits are associated with altered-facies sandstone, almost exclusively in the vicinity of carbonaceous material in the sandstone. Chemical and radiometric data (Shawe, 1976a) show that altered-facies sandstone contains significantly more lead and uranium than does red-beds-facies sandstone. Where altered-facies sandstone has been weathered near the surface it, like carbon-facies sandstone, is shades of buff or light brown owing to limonite formed from oxidation of pyrite. Altered-facies rocks occur in permeable strata in the vicinity of faults and joints and in the 
upper parts of Mesozoic sandstone units in the axial region of the Dolores anticline. Occurrence of altered-facies sandstone along the axis of the anticline suggests alteration by fluids less dense than formation water, and possibly warmer. Alteredfacies sandstone is more voluminous and widespread than is carbon-facies sandstone, but it is less voluminous and widespread than is red-beds-facies sandstone.

Carbonate and iron minerals were leached, recrystallized, and redistributed as a result of the action of altering solution which caused the formation of altered-facies sandstone. Hematite pigment and detrital black opaque minerals were almost completely destroyed and some pyrite was deposited. Elements such as chromium and vanadium were taken into the altering solution with dissolution of black opaques. Calcite was recrystallized; the higher iron content of calcite in altered facies relative to that in carbon and red beds facies likely came from black opaque minerals. Hematite or goethite (or some other form of hydrated iron oxide) and carbonate minerals were concentrated near the borders of altered facies with red-beds facies, or near fractures, and in these places the iron oxides tend to be enriched in vanadium, uranium, and lead. Concentrations of these secondary iron minerals in places display roll-like forms similar to those of the uraniumvanadium ore deposits (Shawe, 1976a).

Altered-facies alteration, an epigenetic (post-lithification) alteration, was controlled by fractures that likely formed during the Late Cretaceous or early Tertiary, inasmuch as the fractures cut Late Cretaceous stratal units. Deposition of uranium-vanadium ore deposits occurred during this interval, as ore deposition was related to rock alteration (discussed in detail in a later section). Some data, such as fluid inclusion measurements that indicate high-pressure formation, suggest that alteration occurred when the sediments were deeply buried near the end of the Cretaceous or in the early Tertiary (Shawe, 1976a). Younger fractures that postdate alteration formed during the late Tertiary and Quaternary.

\section{Source of Barite, and Sulfur and Strontium Isotopes}

High barite content in Salt Wash sandstones in the area overlying the Paradox Basin compared to that of much of the Colorado Plateau (Cadigan, 1967) suggests addition of barite to the Salt Wash in the area of the Paradox Basin. Breit and others (1990) considered the barite to have been derived in large part from solutes from the underlying Pennsylvanian Hermosa Group. Concurrent folding and faulting of the Paradox Formation long before the episode of uraniumvanadium mineralization may have caused upward migration of sulfate-bearing Hermosa fluids into the Salt Wash (Breit and Goldhaber, 1995). I attributed deposition of a fan-shaped part of the Salt Wash Member that eventually defined the position of the Uravan mineral belt to subsidence of the Paradox Basin (Shawe, 1962). Tectonism related to deepening of the Paradox Basin during deposition of the Salt Wash and Brushy
Basin Members in the basin may have induced flow of water that carried barium sulfate into those sediments long before and unrelated to deposition of the uranium-vanadium ores, accounting not only for increased barite content of the Salt Wash, but also the similarity of barite $\delta^{34} \mathrm{~S}$ throughout the Salt Wash.

Sulfur-isotope analyses by George Breit (written commun., circa 1990) of $\delta^{34} \mathrm{~S}$ content in five barite samples from red-beds-facies sandstone drill cores from holes in Disappointment Valley (Shawe, 1976a, pl. 1) average +12.62 (range 11.47-13.4); $\delta^{34} \mathrm{~S}$ content of two samples of carbon-facies sandstone average +12.2 (range $10.9-13.5$ ); and $\delta^{34} S$ content of five samples of altered-facies sandstone (two samples actually from sandstone in the Brushy Basin Member immediately above the Salt Wash) average +11.02 (range 9.8-12.0). These values compare to an average $\delta^{34} \mathrm{~S}$ content of Hermosa sulfate of about +11 to +13 per mil.

Because introduced barite-forming solutions did not modify red-beds-facies sandstone, similarity of isotope values in altered sandstone to those in the red beds as well as to those in the Hermosa Group may be coincidental; the similarities, however, do not negate the Hermosa as a source of altering fluids.

\section{Form and Size of the Uranium-Vanadium Deposits and Constituent Ore Bodies}

Two general forms of ore bodies are common in the Morrison Formation in the district, one tabular and the other the so-called "roll." Some deposits consist mostly of tabular ore bodies and others are dominantly of roll bodies, although both types display elements of the other, and in many places tabular bodies are continuous with roll bodies. Some deposits have both types significantly developed. The two types were deposited by the same general process and at the same time; differences in their forms were dictated by local differences in the lithologies of the host sandstone units that controlled fluid movement.

Details of the forms of roll ore bodies related to lithologic differences, and element distributions within rolls, provide strong evidence of deposition of the bodies at an interface between two solutions. The interface interpretation was first proposed by Fischer (1942). Continuity of roll ore bodies with tabular bodies indicates that the tabular bodies also formed at a solution interface.

In the following discussion of ore types, the tabular deposits described are the Ike No. 1, King No. 4, Brighton, Mayday, Frenchy Incline mines, and Moqui Jug and Depression claims; these mines are given as a sequence from wholly tabular, to deposits generally with increasing numbers of intimately associated roll forms. The roll deposits described are of the Cougar, Strawberry Roan, and Bennie T. No. 1 mines; they are presented as various examples of rolls (with tabular associations) whose forms were influenced by varied lithologic-stratigraphic relations. 
Sizes of deposits (and constituent bodies) vary considerably within the Slick Rock district. An evaluation of size distribution made in 1956 (Rogers and Shawe, 1962) indicated 6 percent of the total number of mined ore deposits were in the size range of 10,000-100,000 tons ( 1 percent greater than 30,000 tons), 14 percent were in the size range 1,000 10,000 tons, 28 percent were in the size range $100-1,000$ tons, and 52 percent were in the size range less than 100 tons. Three-fourths of the mined tonnage was in deposits containing greater than 5,000 tons. Following 1956, several large deposits containing more than 30,000 tons each were mined at depths substantially greater than earlier-mined deposits. Relatively few smaller ones have been mined in the later period because of unfavorable economic factors.

\section{Tabular Ore Deposits (Simple Ore Bodies and More Complex Forms)}

Known uranium-vanadium deposits in the Moss Back Member of the Chinle Formation in the district are sparse tabular layers that are of small size. Mineralized zones observed in the basal Moss Back in the Dolores River Canyon are tabular layers no more than a foot or so thick and a few feet across. One such deposit at the Bullsnake No. 2 prospect is illustrated in cross section in figure 9. The deposit (body) is an undulated layer that lies along bedding in a crossbedded conglomerate layer at the base of the Moss Back. Other than the setting and general size and shape of these deposits, no further details of the mineralized rock have been determined. Shapes and sizes of mineralized bodies in the Moss Back encountered by drilling in Summit Canyon (Shawe and others, 1968) are not known.

Tabular ore bodies in the ore-bearing sandstone in the Salt Wash Member tend to be simple elongate oval lenses of mineralized rock suspended in bedded to massive sandstone. Some rest in part on underlying mudstone. They average about $3 \mathrm{ft}$ thick and vary from 1-20 ft thick. They are a few feet to more than $500 \mathrm{ft}$ long and contain a few tons to several tens of thousands of tons of ore. Long dimensions of the bodies are aligned with elongate sedimentary structures. The top and bottom boundaries of tabular ore bodies may be almost planar or they exhibit smoothly to irregularly undulated surfaces, and the surfaces in part reflect variations and complexities of the detailed sedimentary structures in the host rock. Tabular bodies show sharp to gradational transitions into unmineralized sandstone, and commonly terminate abruptly against minor mudstone or claystone seams. Laterally, tabular bodies pinch out, terminate by gradual decrease in grade, or end abruptly at lithologic boundaries. Ore bodies with simple geometrical outlines are found in homogeneous sandstone, whereas more complexly shaped ore bodies occur in heterogeneous rock.

Some ore deposits consist of a single tabular ore layer, but many deposits contain two or more closely spaced ore

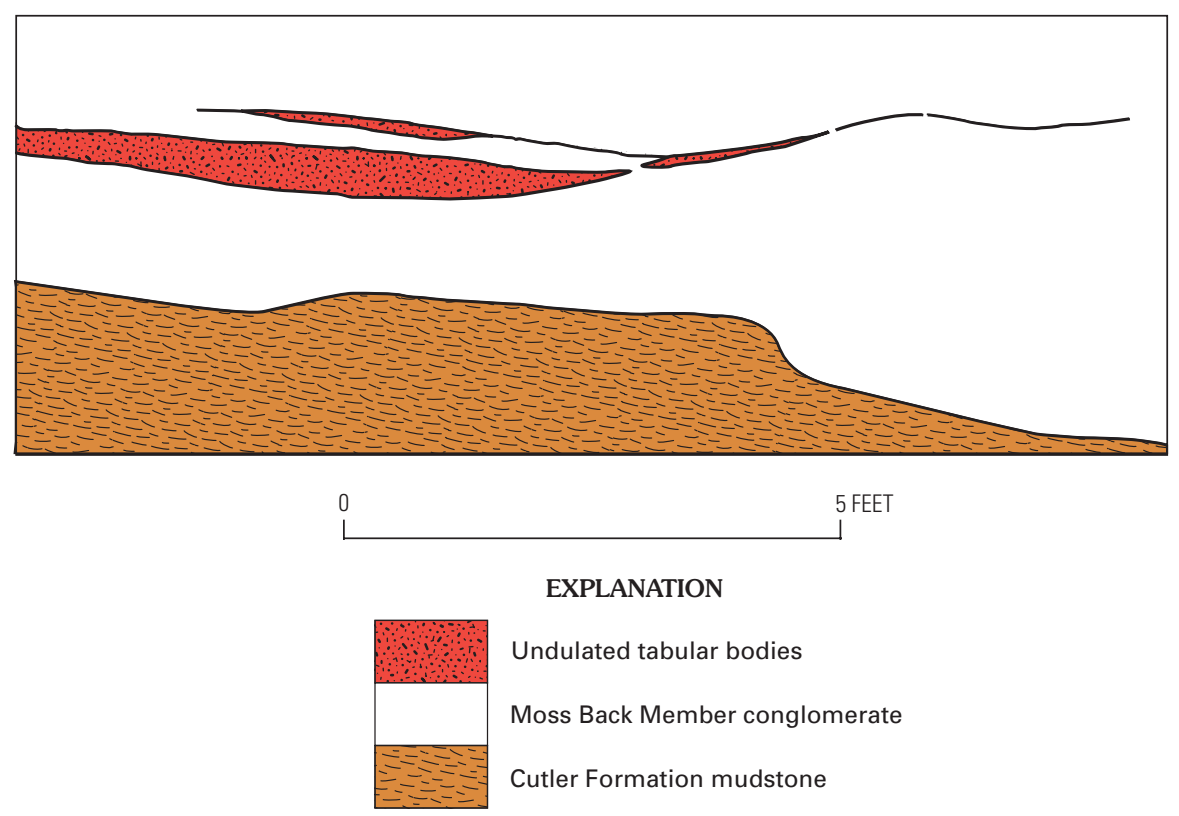

Figure 9. Cross-sectional sketch of a small tabular uranium-vanadium ore deposit in the Moss Back Member of the Chinle Formation (Triassic) at the Bullsnake No. 2 prospect, Dolores River Canyon. Thin undulated tabular bodies (red) lie along bedding in crossbedded conglomerate layer (unpatterned) at the base of the Moss Back. Dashed pattern below conglomerate is reddish-brown mudstone of the Cutler Formation (Permian). A complete measured section of the Moss Back Member at this locality is given in Shawe and others (1968, p. A29). 
layers (ore bodies) connected by thin layers of mineralized rock, and many are connected to associated roll ore bodies. The tabular ore bodies in many places are at about the same stratigraphic level and connected by thin mineralized layers, but in some deposits they are at different levels, may not be connected, and commonly overlap one another.

Ore minerals within tabular ore bodies are more abundant along certain beds and in trashy zones that contain abundant clay galls and pebbles, and carbonaceous material. Infinite variety of form, however, is exhibited amongst different ore bodies.

The deposit at the Ike No. 1 mine, Incline No. 1, in the Radium group (pl. 8; fig. 10; locations of the mines are given in Appendix A, and keyed to pl. 1) is a somewhat undulated elongate tabular ore body about $520 \mathrm{ft}$ long, as much as 120 $\mathrm{ft}$ wide, as much as $15 \mathrm{ft}$ thick, and of northeasterly trend. Mapped dimensions suggest a total of about 30,000 tons of ore in the body (calculations based on 14 cubic $\mathrm{ft}$ of mineralized sandstone per ton, Bush and Stager, 1956, p. 137). At the time of mapping much of this tonnage was left in the ground, unmined in pillars. The perspective cutaway diagram of figure 10 shows the Ike mine ore body as a simple lens, modified by minor "splits" or tongues above and below the body in its southwestern part. Part of the undulatory character of the ore body resulted from its deposition mostly against an undulated mudstone layer at the base of the ore-bearing sandstone (pl. 8). The thicker part of the ore body was localized generally in a channel in underlying mudstone, as indicated in the sections of plate 8 and as suggested by the form of the body illustrated in the perspective diagram (fig. 10).

The King No. 4 mine is a more complex tabular ore body, as shown in a perspective cutaway diagram (fig. 11). The deposit is an elongate tabular lens similar to the deposit at the Ike mine, but it is more irregular in plan outline, and it displays more complex splits or tongues above and below the main ore layer, or that merge laterally with the main ore layer (fig. 11; pl. 9). General trend of the deposit is south-southeast. The King No. 4 ore body is about $540 \mathrm{ft}$ long, as much as 170 $\mathrm{ft}$ wide although much narrower in places, and as much as 14 $\mathrm{ft}$ thick but generally much thinner. Mapped dimensions suggest a total of about 11,000 tons of ore in the body. The King No. 4 ore body appears suspended medially in bedded, fine- to medium-fine-grained sandstone of the ore-bearing sandstone unit; splits or tongues of the main ore layer were controlled by the presence of thin mudstone layers and lenses (pl. 9).

At the Brighton mine, Radium group of mines, a series of tabular ore bodies generally connected by thin low-grade mineralized layers form an elongate southeast-trending cluster about 1,200 ft long and $250 \mathrm{ft}$ wide (pl. 10). Individual ore bodies tend to be elongated parallel to the trend of the cluster, although they are somewhat irregular in plan outline. The ore bodies are undulated or irregularly "rolling" lenses as much as $200 \mathrm{ft}$ long, $100 \mathrm{ft}$ wide, and $8 \mathrm{ft}$ thick. Mapped dimensions of the ore bodies suggest that an aggregate of about 11,000 tons of ore was mined from the Brighton mine deposit. Two of the ore bodies connect with small rolls that trend southeast, parallel to the elongate trend of the cluster, as well as to the orientation of a measured current lineation.

Complex and irregular thin tabular layers of ore and a few small rolls (only one large roll) were mined at the Mayday mine, Spud Patch group of mines (pl. 11). At the Mayday mine several interconnecting undulated layers form an elongate deposit about $500 \mathrm{ft}$ long and as much as $200 \mathrm{ft}$ wide that trends about $\mathrm{S} .10^{\circ} \mathrm{E}$. Small ore pods occur a few tens of feet from the edges of a contiguous deposit. The ore layers lie mostly just above and in part below an irregular mudstone layer within sandstone. The mudstone layer, $1-4 \mathrm{ft}$ thick generally, is discontinuous and has splits or tongues above and below it.

The ore deposit at the Frenchy Incline mine, Legin group of mines, consists of several irregular more-or-less equidimensional tabular lenses that form an elongate east-northeasttrending cluster about $650 \mathrm{ft}$ long and as much as $250 \mathrm{ft}$ wide (pl. 12). Thickness of the mined ore layers varied from about $1 \mathrm{ft}$ to as much as $8 \mathrm{ft}$. Several roll ore bodies occur in the southwesternmost and northeasternmost tabular lenses; their mapped trends vary between nearly east and about southeast, and they are oblique to almost normal to the trend of the elongate cluster. Heights (as much as $10 \mathrm{ft}$ ) of the roll bodies were probably generally greater than thicknesses of the tabular layers connected to the rolls (positions of the rolls shown on pl. 12 could not be accurately located). Some rolls were small and undulated. Locally, current lineations were mapped nearly parallel to the trends of nearby ore rolls.

The ore deposit at the Moqui Jug and Depression claims, Spud Patch group of mines, forms an irregular, "patchy" cluster of ore bodies that shows a general southeasterly trend (pl. 13). The ore bodies are irregular tabular layers and rolls that are localized in and adjacent to a zone of irregular and discontinuous layers and lenses of mudstone in the lower part of the ore-bearing sandstone. The principal patch of mineralized ground as seen on the map is a roughly equidimensional irregular area within which are irregular zones of unmineralized ground, generally both east- and southeast-trending. West-trending and southeast-trending prongs of mineralized ground which extend from the deposit at the Moqui Jug and Depression claims contain roll ore bodies aligned with the trends of the prongs. Tabular ore in the west-trending prong bifurcates to form rolls that lie parallel to the long dimension of the tabular body (pl. 13 , sections $D-D^{\prime}, E-E^{\prime}$ ). In the north part of the deposit southeast-trending rolls lie roughly parallel to the northeast margin of the deposit. Smaller patches of mineralized sandstone southeast of the main deposit show east- to southeast-trending segments; east-trending roll ore bodies lie within and parallel to an east-trending elongated patch.

Together, features of the tabular ore deposits (and associated rolls) indicate that ore deposition resulted from interaction between two fluids of different density at an interface localized by permeability (lithologic) variations which affected flow of an introduced fluid. 


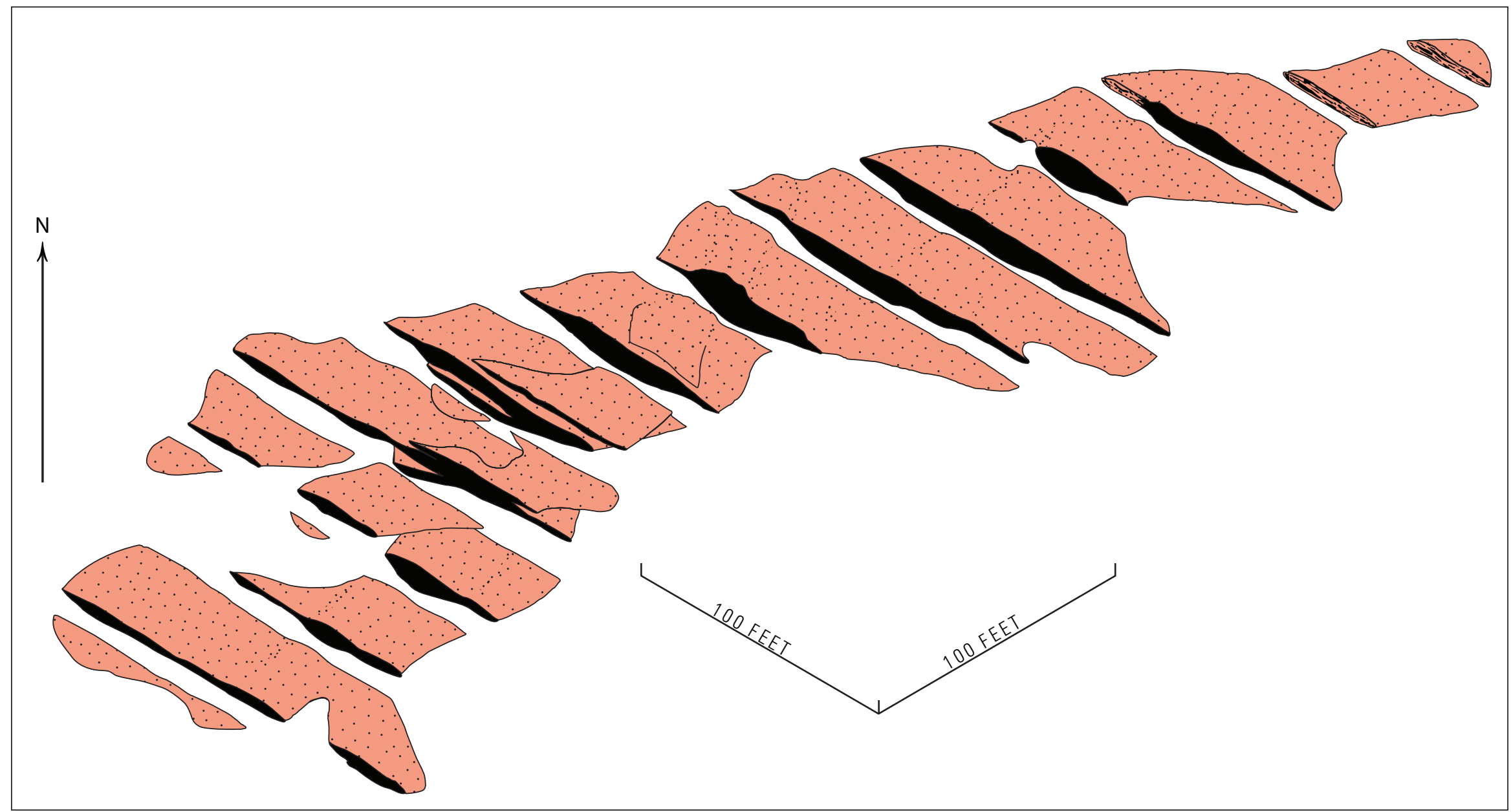

Figure 10. Perspective cutaway diagram of the uranium-vanadium ore deposit at the lke No. 1 mine, Incline No. 1, Radium group of mines. Positions of equally spaced cross sections through the cutaway diagram are not shown on the map on plate 8 . 


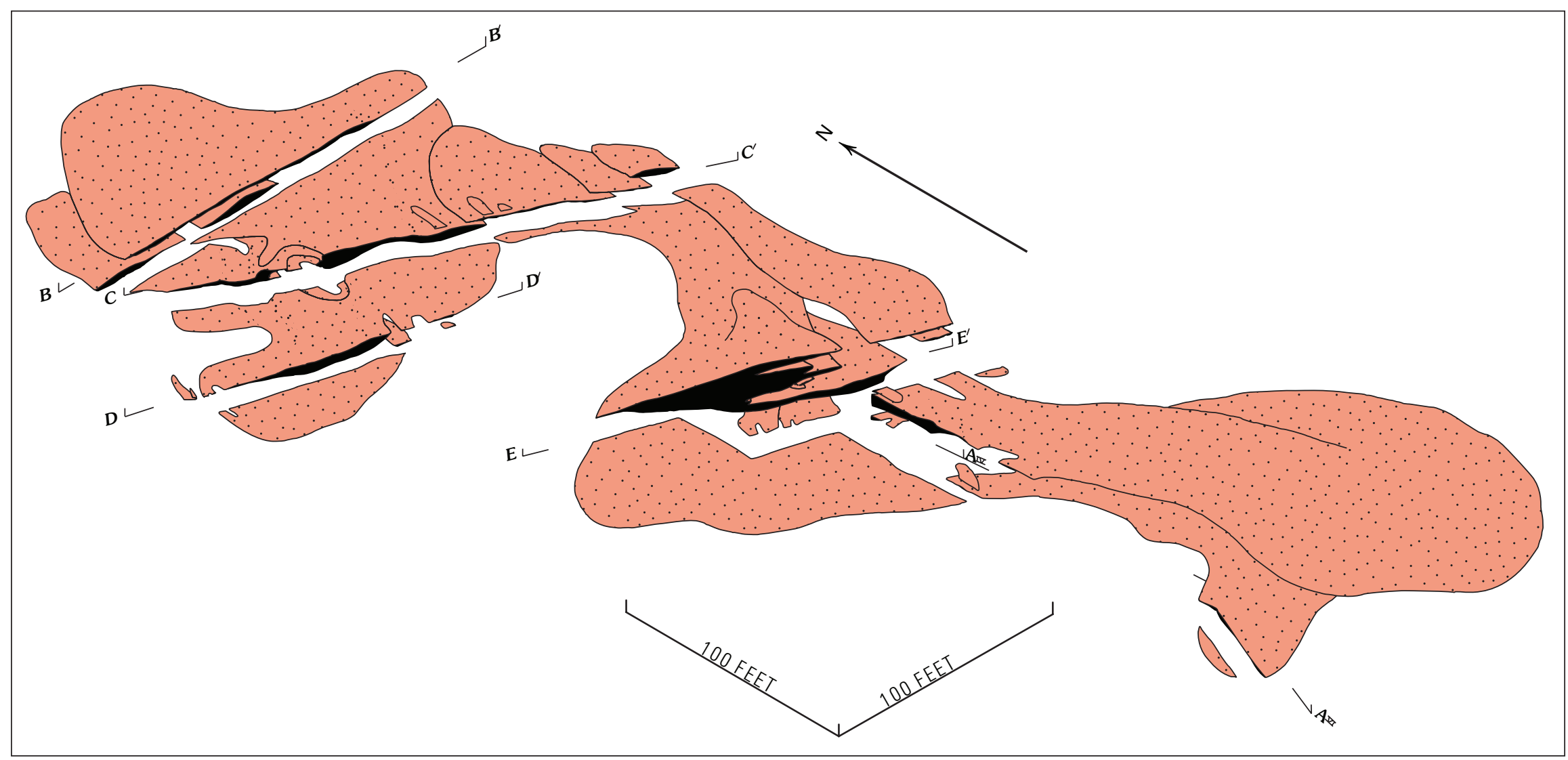

Figure 11. Perspective cutaway diagram of the unanium-vanadium ore deposit at the King No. 4 mine, Legin group of mines. Positions of lettered cross sections through the cutaway diagram are shown on the map on plate 9 . 


\section{Roll Ore Deposits}

In an earlier report (Shawe, 1956a, p. 239-240), I described roll ore bodies as generally layered bodies that cut across sandstone bedding in sharply curving forms (see also Fischer, 1942). In cross section, rolls commonly show "C", "S", and "socket" shapes, but in plan are linear (with welldefined longitudinal axes); many elongate rolls curve abruptly at their extremities into "noses." Most roll ore deposits (some consisting of numerous roll bodies) are near the base of thick sandstone units where several thin well-defined mudstone layers are interbedded with thin sandstone layers (for example, fig. 8). Rolls commonly terminate against an upper and lower mudstone layer, but in places they are split into two distinct rolls by a third thin mudstone layer. Rolls may be continuous for several hundreds of feet along thin sandstone layers. Essentially, roll ore bodies in any particular sandstone layer bounded by mudstone layers are all segments of a continuous roll front, and in places rolls flatten into tabular form. The axes are characteristically sinuous in plan and commonly double back on themselves (at noses) so that cross sections through loops in the roll fronts show mirror images of the roll shapes on either side of the loops (for example, figs. 12, 13, and 14). Another example of opposed roll ore bodies is shown in figure 15 , which also shows the inferred position of deposition of uranium-vanadium ore at an interface between an introduced fluid and trapped connate (formation) water. The concept of ore deposition at an interface will be discussed more thoroughly in later sections of this report.

Roll ore bodies in the Slick Rock district range from several inches to more than $5 \mathrm{ft}$ wide, a foot or so to almost $20 \mathrm{ft}$ high, several feet to several hundreds of feet long, and contain a few tons to a few thousands of tons of ore. Detailed mapping of sedimentary structures in mine workings has shown the general coincidence of the long axes of rolls with the trend of sedimentary structures such as current lineations. Some rolls lie against mineralized carbonized logs (one example shown in fig. 8), or rolls are indented where logs lie across their general trends.

Rolls are bounded by fractures that separate mineralized rock from barren rock (figs. 16A,B, 17, 18A, $B$, and 19A,B). Commonly, the concave surfaces of rolls show sharp transitions into barren rock, whereas the convex sides of rolls show more gradual transitions into barren rock, or even may be continuous laterally into tabular ore bodies. Within roll ore bodies, ore minerals are more abundant along certain bedding layers, in zones with abundant clay galls and pebbles, and carbonaceous material (figs. 20, 21, and 22).

The uranium-vanadium ore deposit at the Cougar mine, Lower Group of mines, perhaps epitomizes roll ore bodies of the Colorado Plateau sandstone-type ore deposits. The deposit consists of a large number of interconnected roll ore bodies whose subparallel axes trend about southeast; in aggregate the roll ore bodies form a southeast-trending ore deposit whose erosional remnant is almost $1,900 \mathrm{ft}$ long and about $800 \mathrm{ft}$ wide (pls. $4,14,15$, and 16). Plate 14 is a geologic map of the
Cougar mine showing essential elements of the deposit and its host sandstone. Cross section lines on the map $\left(A-A^{\prime}\right.$ to $\left.X-X^{\prime}\right)$ show the positions of geologic cross sections in plate 15 which were used to construct the prospective diagram of the roll ore deposit depicted in plate 16 .

Plate 16 shows that the Cougar ore deposit is essentially only a few extremely convoluted single ore layers. The ore layers are made up of a large number of ore rolls, many of which flatten both laterally and longitudinally into thin interconnecting tabular layers. A more detailed perspective view of a small part of the Cougar deposit at its west-central edge (sections $B-B^{\prime}, C-C^{\prime}$, and $D-D^{\prime}$ on pl. 14) is shown in figures 12,13 , and 14. The axes of the ore rolls (shown as single lines on pls. 4 and 14) generally are linear and subparallel, although they locally are sharply curved where they "double back" on themselves. Such points mark the "tongues" or "noses" of roll ore bodies, many of which can be seen on plate 16; the detailed appearances of a few of these are shown in figure 14 . The complex system of generally subparallel interconnected roll ore bodies, as just noted (also pls. 5 and 16), occupies a braided stream system of coalescing elongate sandstone lenses (see parallelism of roll axes and current lineations shown on pls. 4 and 14).

Figures $16 A, B$ provide perspective views of a typical roll surface showing the development of loops in an otherwise linear roll axis. The perspective cross sections of plate 15 and figure 12 show that the positions, sizes, and shapes of the ore rolls in sandstone have been controlled in detail by generally thin mudstone layers at or near the base of the ore-bearing sandstone. Figure 8 also shows this relationship.

The uranium-vanadium ore deposit at the Strawberry Roan mine located about $1 \mathrm{mi}$ south of the Legin group of mines is a particularly good example of a deposit that contains paired subparallel rolls whose mirror-image character is seen in cross section $A-A^{\prime}$ (pl. 4). The rolls are aligned with the east-northeasterly trend of greatest permeability of elongate sandstone lenses. Current lineations that suggest the trend of greatest permeability in sandstone were not recorded on the Strawberry Roan mine map; the trend is suggested by the subparallel alignment of fossil carbonized logs which were mapped near the mine portal (pl. 5).

At the Bennie T. No. 1 mine, Charles T. group of mines, an intricate network of interlayered crossbedded sandstone lenses and thin mudstone layers has resulted in the formation of a complex assemblage of subparallel fingerlike roll forms (pl. 17). Mapped current lineations and the trend of a fossil carbonized log at the mine are subparallel to the south-southeast trend of the roll ore bodies.

The forms of roll ore bodies, as obviously controlled by lithologic variations in enclosing rocks that reflect permeability differences, indicate that an introduced mineralizing fluid was conducted along permeable pathways. Precipitation of minerals along the margins of the permeable pathways implies the presence of a precipitating agent, that is, a formation fluid of different chemical composition through which the introduced fluid moved. This presence, in places of Leisegang 


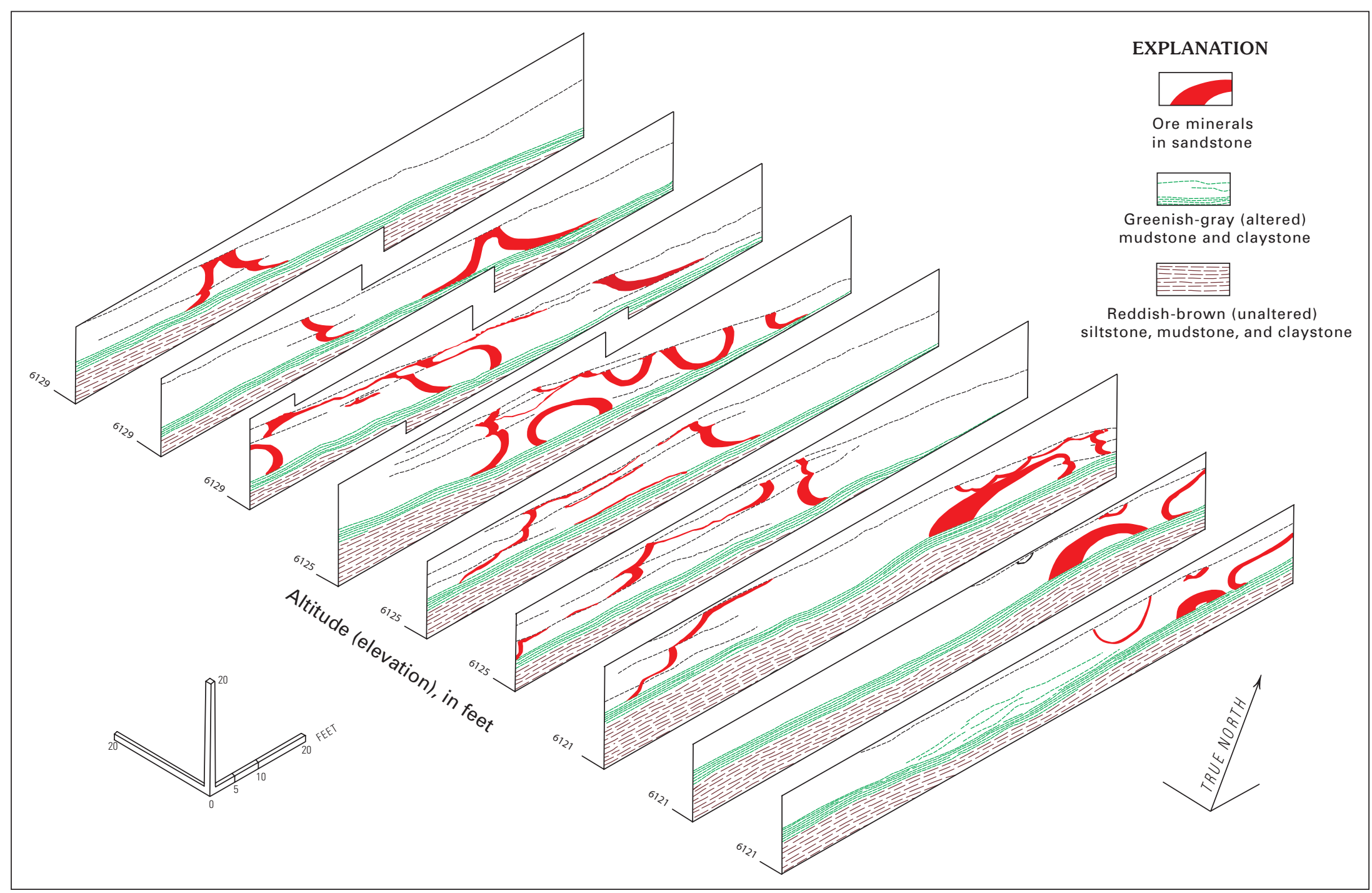

Figure 12. Perspective geologic cross sections of roll ore bodies, west-central edge of the Cougar mine, Lower group of mines (after Shawe and others, 1959, fig. 6). 


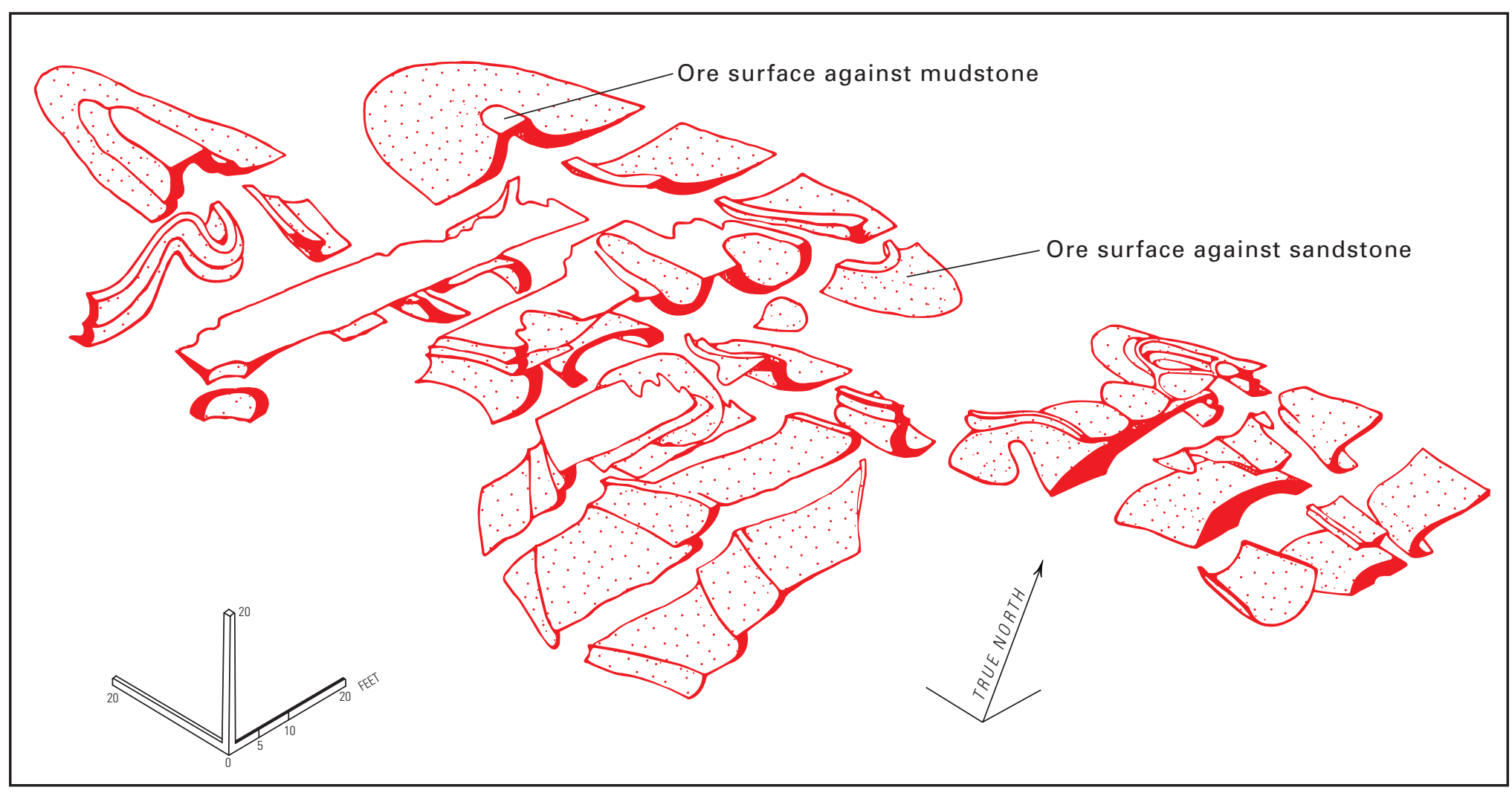

Figure 13. Perspective cutaway diagram of roll ore bodies, west-central edge of the Cougar mine, Lower group of mines (after Shawe and others, 1959, fig. 7). 


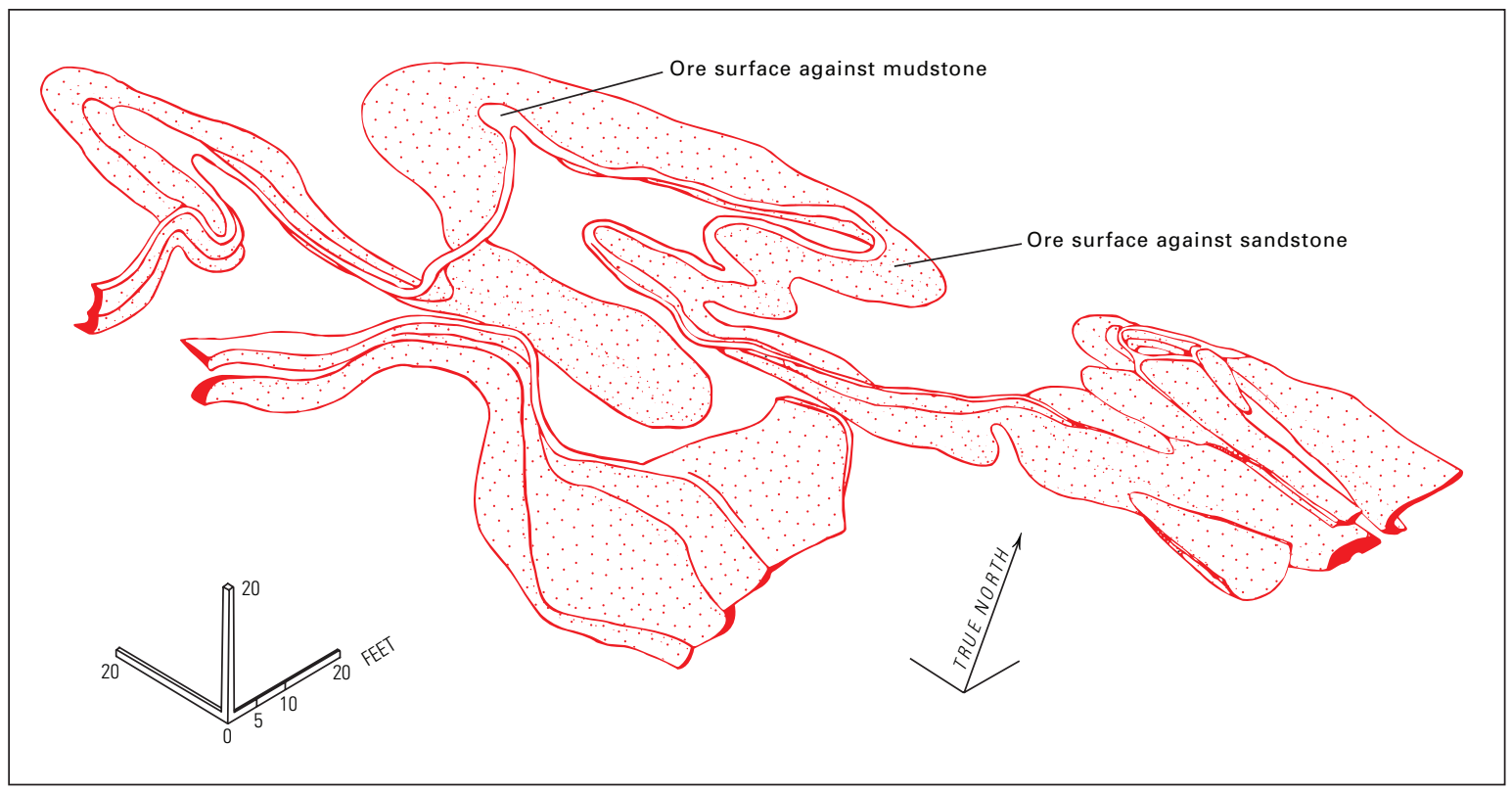

Figure 14. Perspective view of part of a roll ore deposit showing the sinuous interconnecting surfaces of the rolls, west-central edge of the Cougar mine, Lower group of mines (after Shawe and others, 1959, fig. 8).

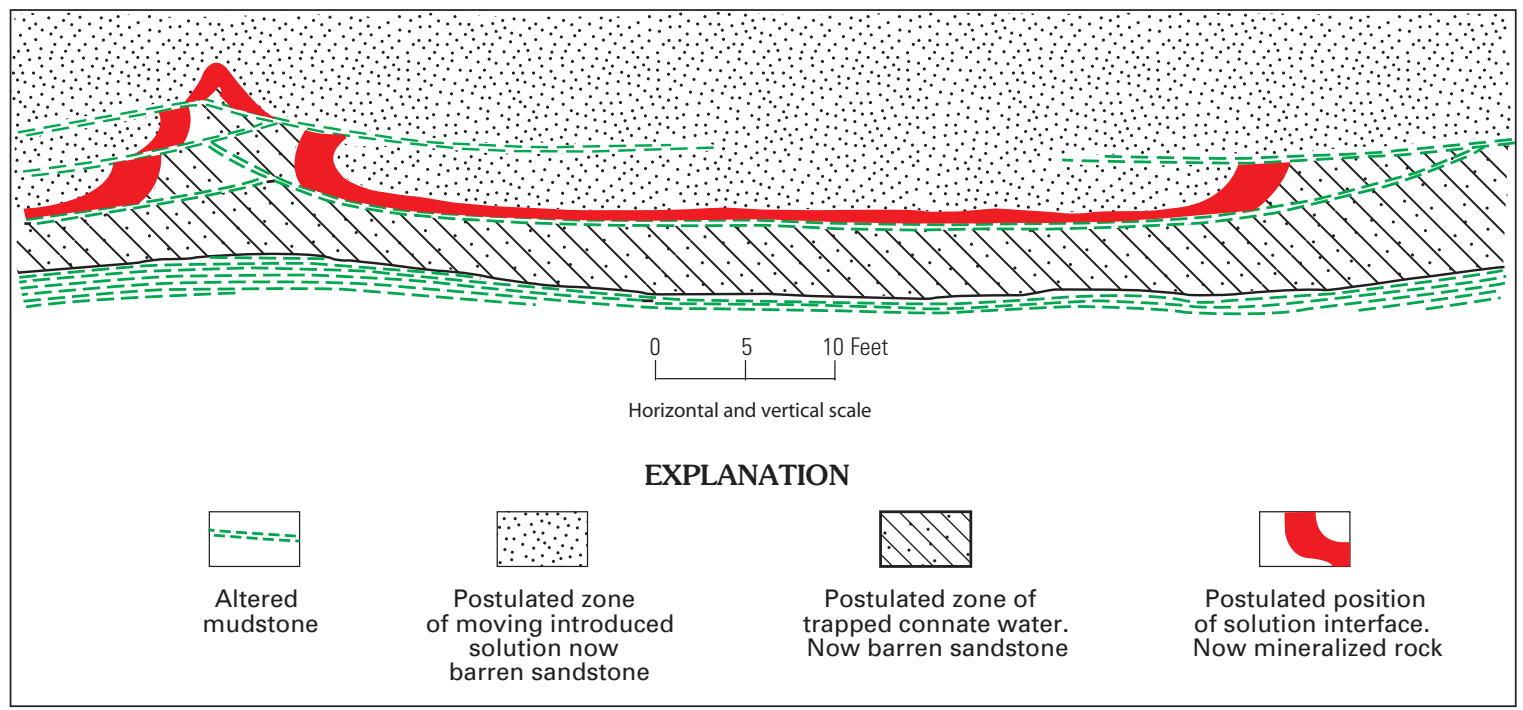

Figure 15. Diagrammatic cross section of rolls in sandstone layers near the base of the ore-bearing sandstone of the Salt Wash Member of the Morrison Formation, Cougar mine, Lower group of mines (after Shawe and others, 1959, fig. 9).

ring-like forms of deposited minerals within rolls, indicates that diffusion at the interface between introduced fluid and formation fluid was part of the interaction, and the nature of the rings suggests diffusion through a gel (humic acid?).

\section{Details of Ore Body Form and Texture}

Details of ore body form and texture show the effect of minor variations in lithology upon the form and position of the interface between the inferred two fluids whose interaction resulted in ore mineral precipitation. In the following descriptions, several minor features of both roll and tabular ore bodies are described and then interpreted, inasmuch as the specific features immediately suggest an interface control, as well as other subtle controls on deposition of the ore bodies.

Figure 17, a photograph of the inner (concave) bounding surface of a mined-out roll ore body in the southeast part of the Cougar mine ore deposit shows how a subtle bedding variation in host sandstone has modified the shape of the roll. A diastem that separates horizontally bedded fine-grained 


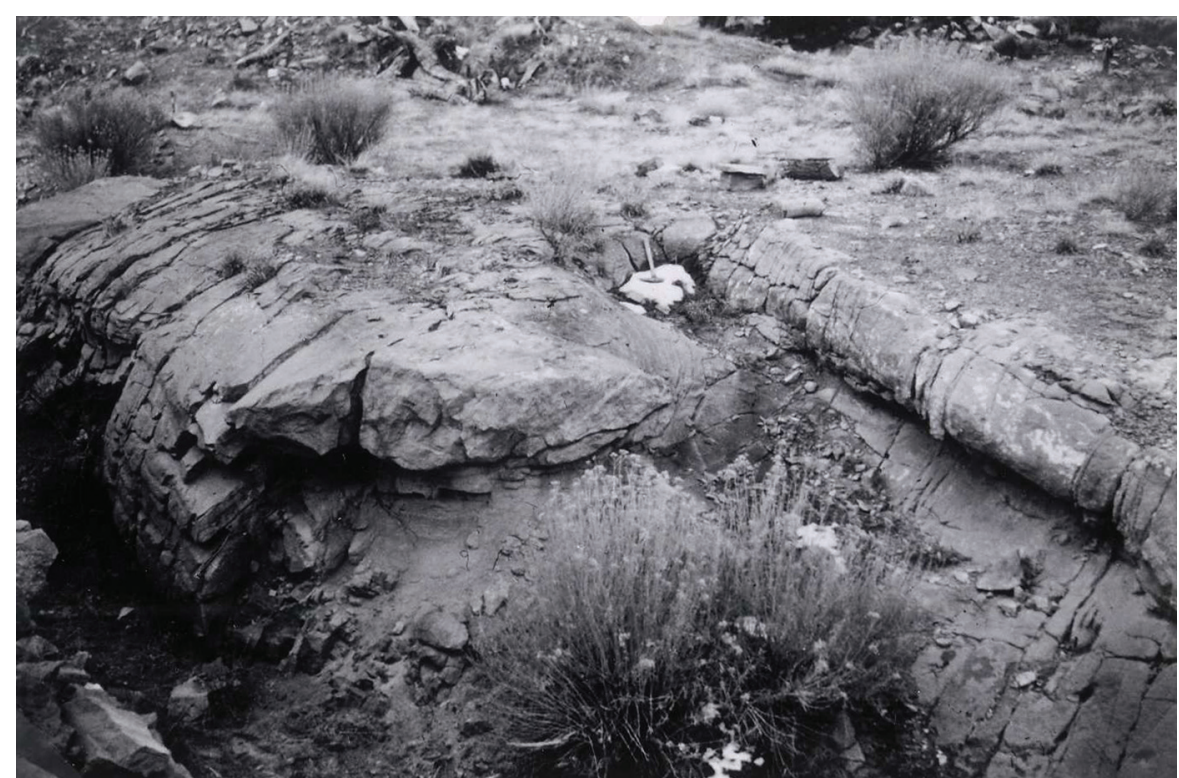

A

Figure 16A. Photograph of axial "noses" in a mined-out roll in the uppermost sandstone unit of the Salt Wash Member of the Morrison Formation (about $10 \mathrm{ft}$ thick) just below a conglomeratic sandstone layer (about $5 \mathrm{ft}$ thick) at the base of the Brushy Basin Member of the Morrison, Radium group of mines. The curved and convoluted surface of the sandstone is the "inner" or generally concave surface of the mined-out roll ore. The curved surface is bounded by a fracture which formed at the boundary between mineralized and barren sandstone as a result of volume loss within ore during mineralization and later weathering. The roll axis (except in the noses) trends about $\mathrm{N}$. $15^{\circ} \mathrm{E}$. (toward the viewer); prominent joints that postdate formation of the ore body are nearly vertical and strike nearly east to $\mathrm{S} .85^{\circ} \mathrm{E}$. Hammer on snow patch shows scale.

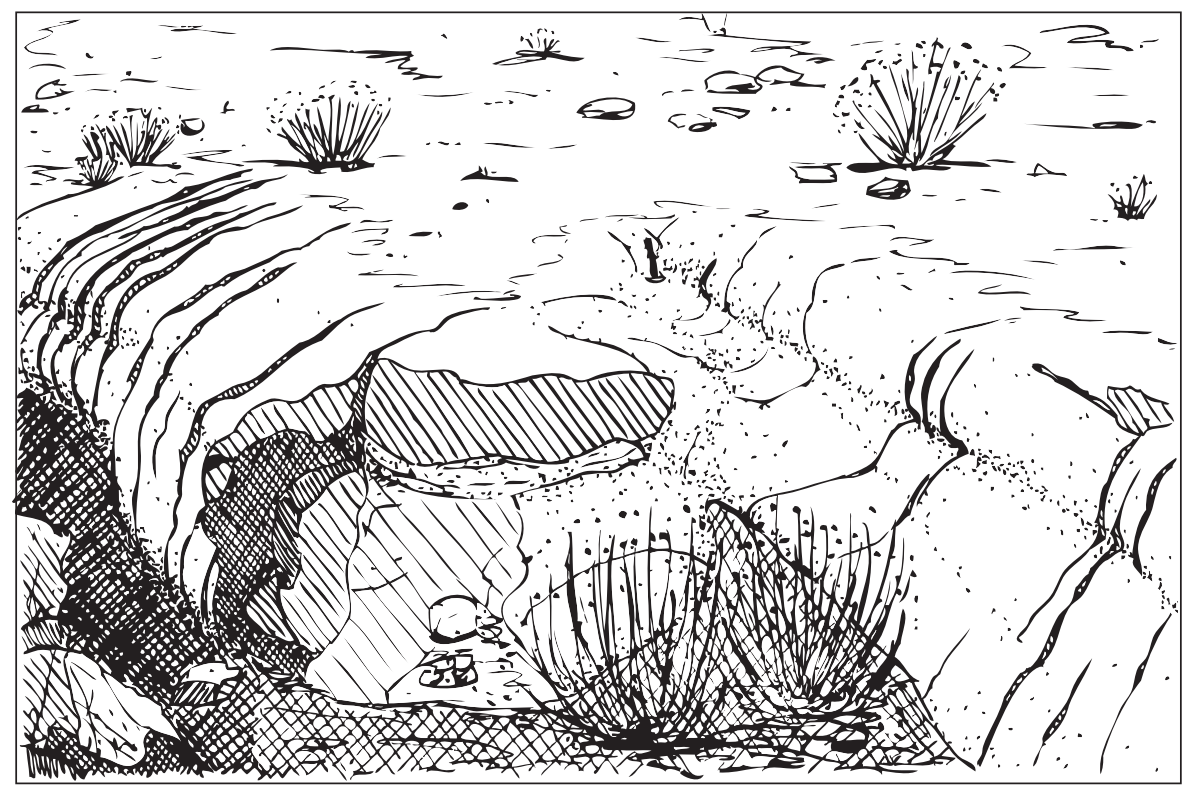

B

Figure 16B. Sketch of photograph shown in figure 16A. 


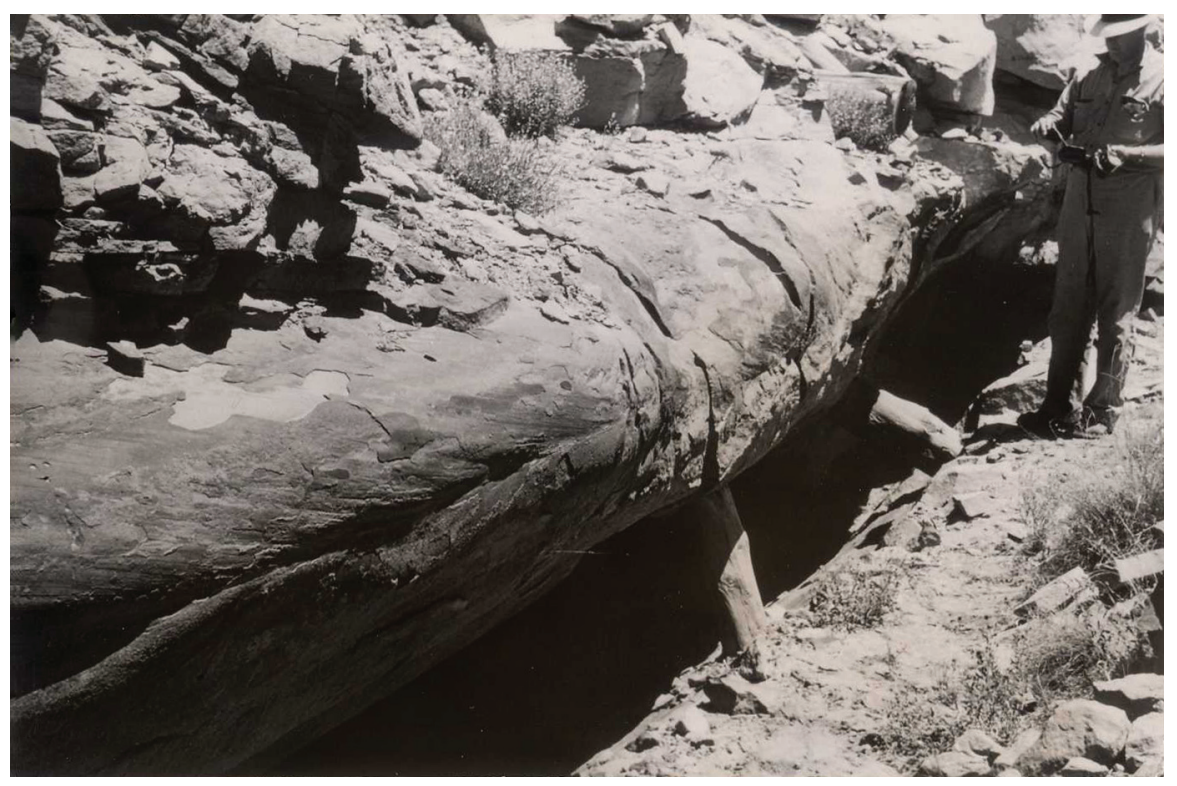

Figure 17. Photograph showing perspective view of the inner (concave) surface of a mined roll, Cougar mine, Lower group of mines. Ore was broken away on a curved fracture that represents the roll surface. View shows the form of a typical C-shaped roll; thickness of mined ore is shown by the length of the stulls. Note how the inner roll surface tends to spall, indicating that the ore boundary here is in fact several closely spaced concentric fractures that reflect compositional and volume variation from barren sandstone into mineralized rock. Walter Keller is photographing the roll surface.

sandstone below from crossbedded fine-grained sandstone above, decreased permeability sufficiently to slightly retard the movement of ore solution that filled sandstone on the concave side of the roll. A small knick in the roll surface formed at the position of the diastem. Figure $18 \mathrm{~A}$ is a more direct view of the same inner surface of the roll; the diagram (fig. 18B) shows in cross section the position and form of the mined out ore relative to the roll surface.

Figures $19 A, B$ illustrate a partially mined roll ore body near the west-central edge of the ore deposit in the Cougar mine. A sketch diagram of this roll drawn from about the same position from which the photograph of figure $19 \mathrm{~A}$ was taken is given in figure $19 \mathrm{~B}$. The photograph shows the subtle influence of bedding layers upon the detailed form of the inner roll surface. The sketch diagram shows the control of local mudstone layers on the exact position and form of the roll ore body. The "nose" of the roll is situated just below a "puncture point" in an otherwise continuous thin mudstone layer, where the sandstone layer in which the roll formed is in contact with overlying sandstone. The relation suggests that introduced solution filling the upper sandstone layer entered the lower sandstone layer at this point, and a more-or-less static interface developed between introduced fluid and trapped formation water. Ore minerals were deposited at this interface to form the roll. Such puncture points in thin mudstone layers above or below noses or tongues of the ore rolls throughout the Cougar mine ore deposit illustrated in plate 15 have localized the positions and orientations of those noses and tongues.
Near the west-central edge of the Cougar ore deposit, just south of the area shown in figures 12-14, a small roll-like hump in a thin tabular layer of ore (fig. 20) demonstrates the effect of pinch-out of a layer of mudstone on the configuration of an ore body. Figure 20 shows the ore layer confined beneath a thin mudstone layer; beyond the pinch-out, ore bulges upward, suggesting that introduced solution flowing beneath the ore layer was no longer confined by the mudstone layer. A small sandy-clayey diastem in sandstone just below the hump of the ore layer probably was not extensive or impermeable enough to prevent upward movement of introduced fluid, but the diastem slightly modified the shape of the roll.

Figure 21 indicates the effect of the varied permeability of thin sandstone layers upon the configuration of a convoluted roll surface. Where sandstone is more permeable, the roll front extends farther into the inferred zone of formation water. The illustration shows how accumulations of carbonaceous and clayey materials have served as local sites of mineral deposition. Concretion-like concentrations of sulfides and selenides, probably mostly chalcocite and eucairite, shown on the concave (introduced solution) side of the roll in figure 21 , occur in similar positions relative to rolls elsewhere in the Cougar mine (for example, fig. 22).

Relations that seem ambiguous are displayed locally in some rolls exposed in mine workings; in such places careful detailed mine mapping revealed that the relations reflect coincidental juxtaposing of normal ore forms. For example, in 


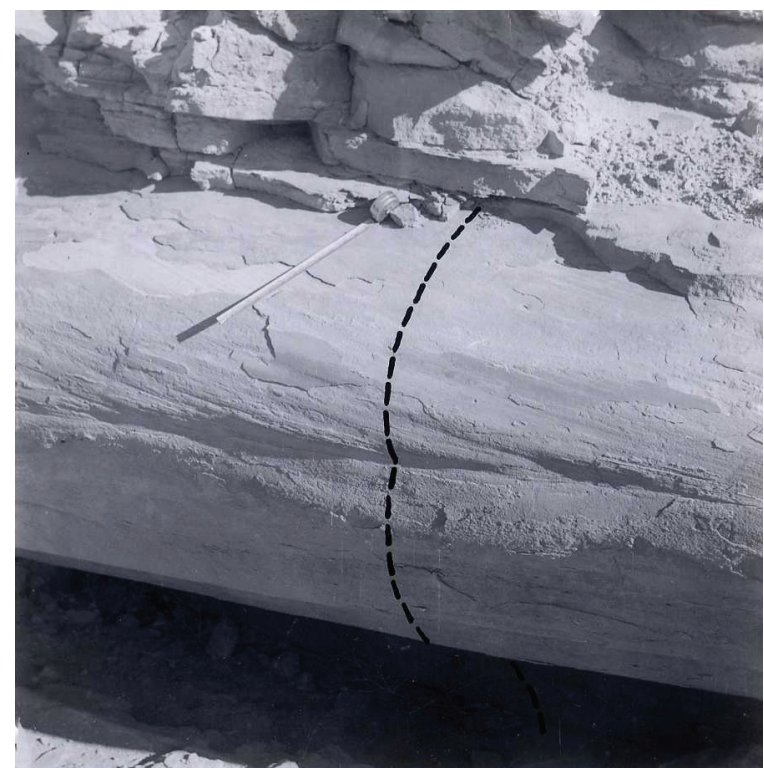

A

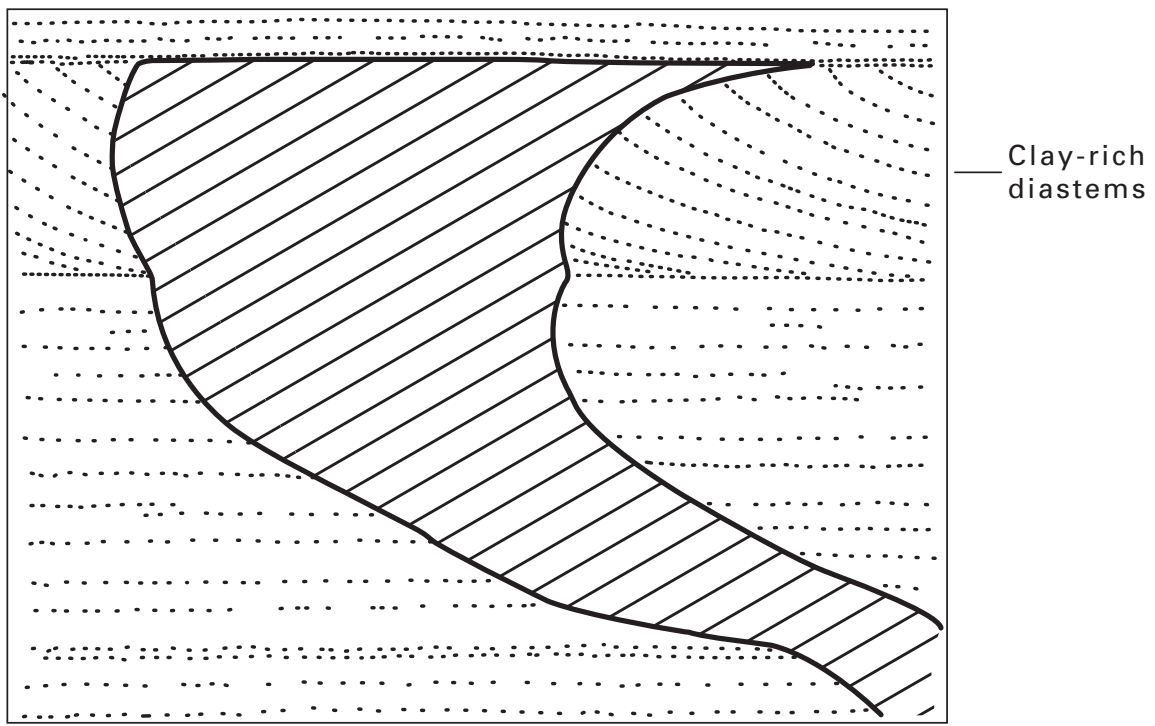

Figure 18A. Photograph showing direct view of the inner (concave) surface of the mined ore roll shown in figure 17. Ore was broken away on a curved fracture that defined the roll surface. Tape measure extended $2 \mathrm{ft}$ shows scale.
Figure 18B. Cross-sectional diagram of the mined ore roll (diagonal lines). Heavy curved line at right traces the fracture; section is shown as dashed line in the photograph $(A)$. The ore surface cuts across bedding, but a minor diastem has modified its shape slightly.

\section{B}

the May Day mine, Spud Patch group of mines, a compound roll with stacked C-shaped forms of opposing concavity (fig. 23) was mapped on one wall of the underground workings. By chance the mine working intersects the axes of two rolls in adjacent sandstone layers at their point of crossing. The roll in the lower sandstone layer is concave to the southwest and trends northwesterly, whereas the roll in the higher sandstone layer is concave to the northeast and trends northerly. The two sandstone layers are separated by a thin clay-filled diastem of low permeability that resulted in independent flow of introduced fluid in adjacent sandstone layers.

Small fragments of impermeable materials, such as pebbles and cobbles of claystone and mudstone, and fragments of carbonized wood imbedded in sandstone in many places have served as permeability blocks and thus have modified the shapes of uranium-vanadium ore rolls and tabular layers.
Figure 24 illustrates the effect of a small fragment of coaly material upon the shape of a thin tabular layer of ore. Two fragments of coaly material lie adjacent to mineralized rock, one at the top of the ore layer and one at the bottom of the ore layer. Only the upper fragment has influenced the form of the ore layer, that is, retarded encroachment of a mineralizing fluid, showing that the encroaching introduced fluid lay above the ore layer whereas passive formation water lay below the ore layer.

Some characteristics of the margins and internal textures of the uranium-vanadium ore bodies, particularly roll ore bodies, suggest mechanisms of ore-mineral precipitation. Many ore bodies, both tabular and roll, display sharply defined contacts between mineralized rock and surrounding rock. Tops and bottoms of tabular ore bodies and both sides of rolls (the concave or "inner" surface and in places convex, or "outer" 


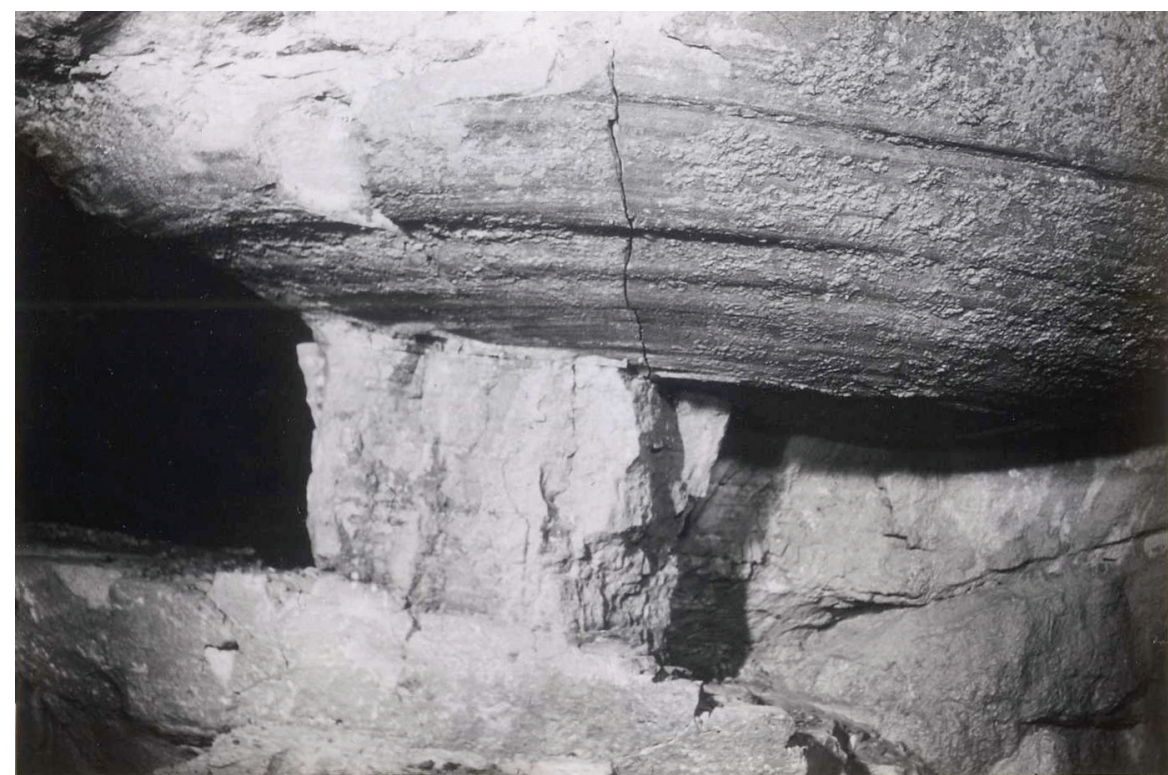

Figure 19A. Photograph of a roll surface in the Cougar mine, Lower group of mines. A layer of unmined ore about $1 \mathrm{ft}$ thick remains between the roll surface and barren sandstone below. Nearly horizontal indentations in the surface mark bedding planes that before mining extended continuously from barren sandstone through mineralized sandstone. Horizontal bedding is faintly visible in the ore layer and in barren rock below.

A

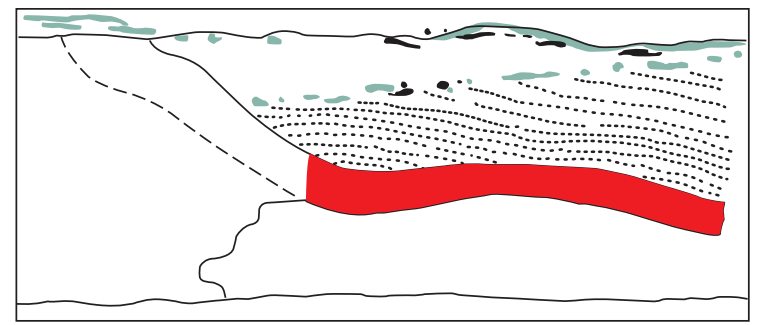

Figure 19B. Sketch diagram of the roll showing details of the relation of uranium-vanadium ore to the enclosing rocks. Ore layer is about $1 \mathrm{ft}$ thick. Green is mudstone; red is ore.

$B$

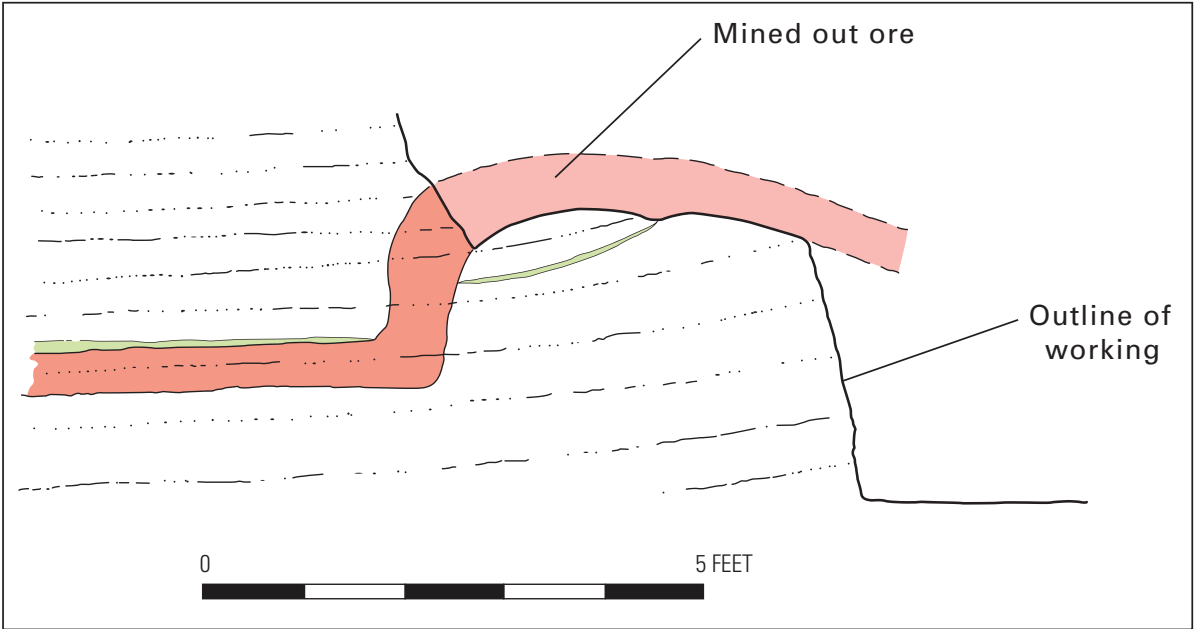

Figure 20. Cross-sectional diagram of a small roll-like hump in a thin tabular layer of uranium-vanadium ore, Cougar mine, Lower group of mines.

surface) mark an abrupt change from ore to barren rock. Mineralized rock generally breaks cleanly from barren sandstone during mining because these sharp margins almost everywhere are fractures, and the forms of the mined-out bodies in places are easily discerned in mine workings, allowing recognition of some textural details. Some textural details are more readily observable where mine workings expose cross sections of ore bodies.

Fractures bounding deposits in unweathered (unoxidized) sandstone probably formed because of volume change that resulted from mineralization (for example, compaction of porous sandstone as detrital and cementing minerals were 


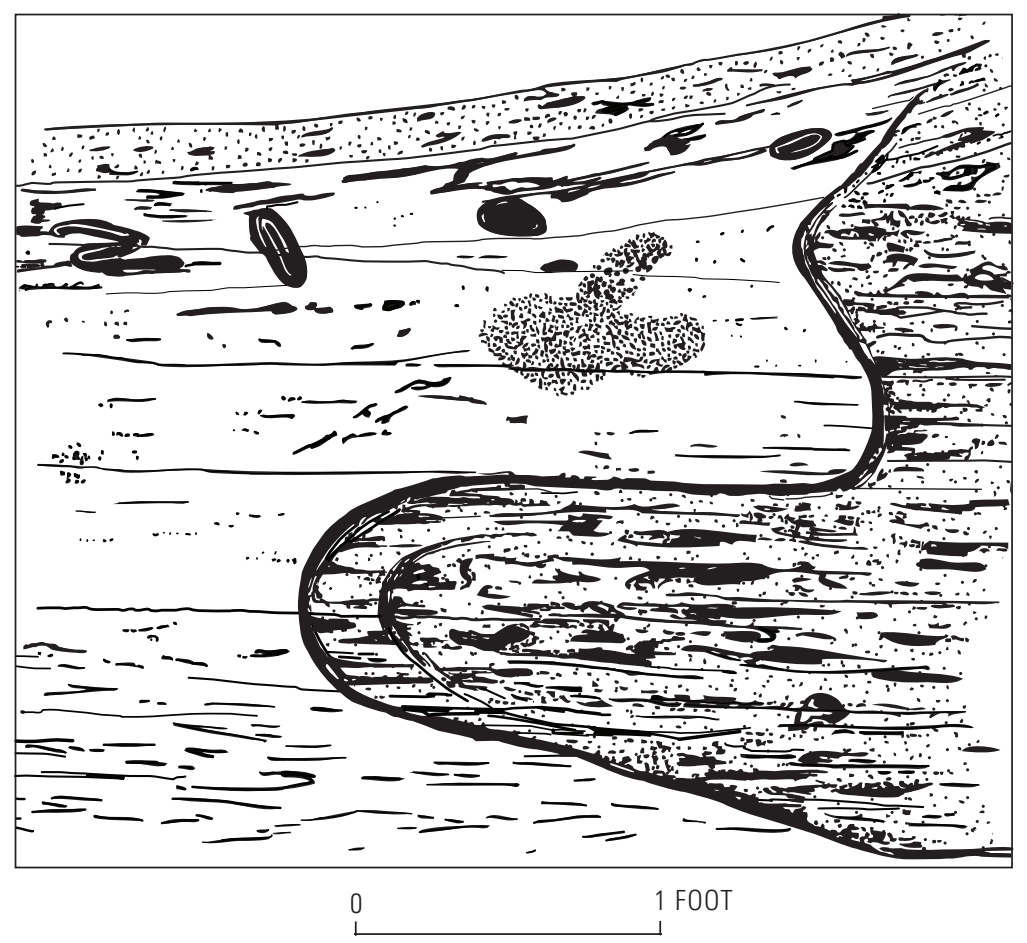

Figure 21. Cross-sectional sketch of a roll ore body in the Cougar mine, Lower group of mines, showing an irregularly curved roll surface whose configuration was influenced by the varied permeability of thin sandstone layers. Mineralized sandstone to the right of the roll surface (curved black layer) contains irregular concentrations of carnotite and gray vanadium minerals (micas and chlorite) partly controlled by bedding layers, and concentrations of carbonaceous material (mineralized sandstone extends several feet to right of diagram); unmineralized sandstone, to the left of the roll surface and beneath the bedding layer that marks the horizontal segment of the roll surface, contains films and small fragments of carbonaceous material on bedding planes, and abundant disseminated limonite; sandstone above this layer and left of the roll surface contains blebs and streaks of chalcocite, eucairite, and volborthite, mostly concentrated on fragments and seams of carbonaceous material; note halos of these minerals around large fragments of coaly material near the top of the sandstone layer; irregular stippled patch in sandstone to the left of the upper part of the roll surface is sandstone that contains abundant limonite; uppermost bed in the diagram is gray and greenish-gray "trashy" mudstone containing a moderate amount of carbonaceous material, volborthite, and carnotite.

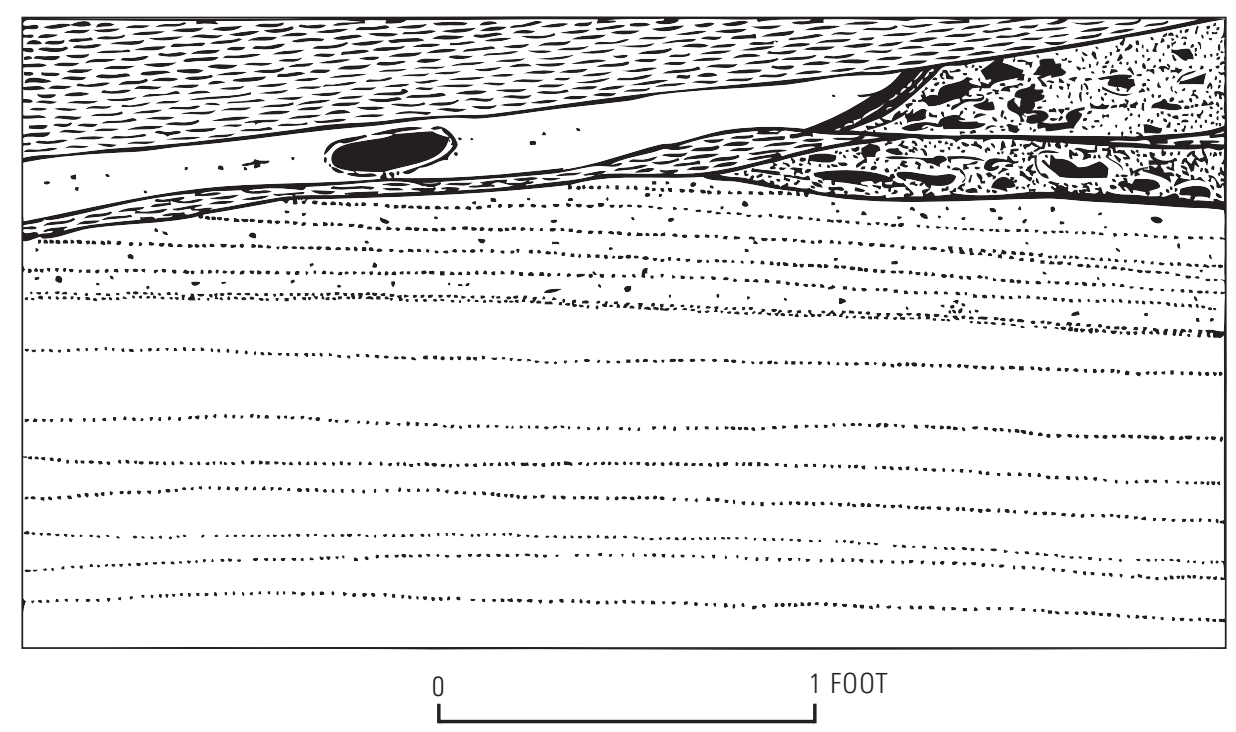

Figure 22. Cross-sectional sketch showing chalcocite nodule in barren sandstone beneath a mudstone layer and left of a flat roll in the Cougar mine. Black patches to the right of and beneath the roll are fragments of carbonaceous material and clay galls impregnated with uranium-vanadium minerals. 


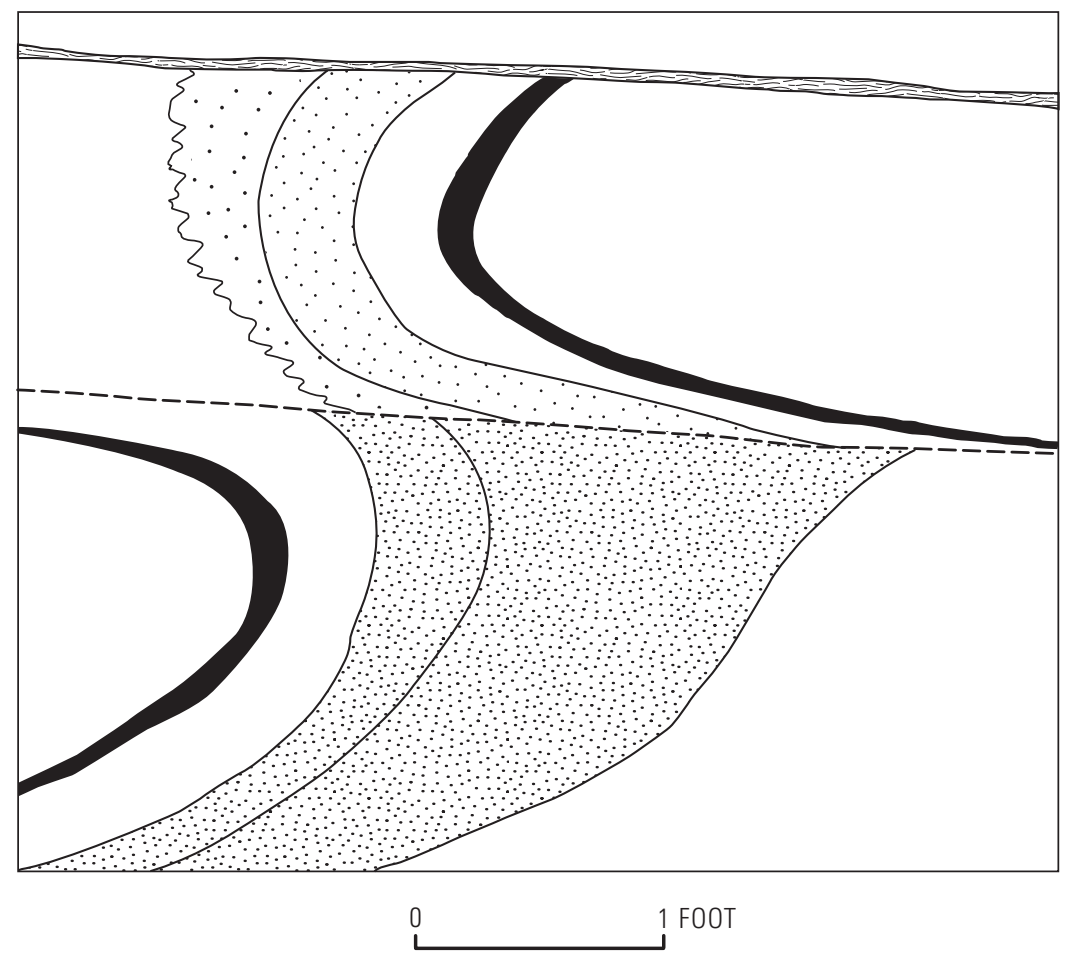

Figure 23. Cross-sectional sketch diagram of two juxtaposed rolls whose axes diverge in either direction from the plane of the section. Chance intersection of the diverging roll axes at the wall of the mine working gives the appearance of a complex roll of ambiguous form. White areas are unmineralized sandstone; black crescents are strongly iron-stained (limonitic) sandstone; heavy stippling denotes uranium-vanadium ore; lighter stippling denotes zones of weakly-mineralized sandstone. Dashes show impermeable claystonemudstone layers.

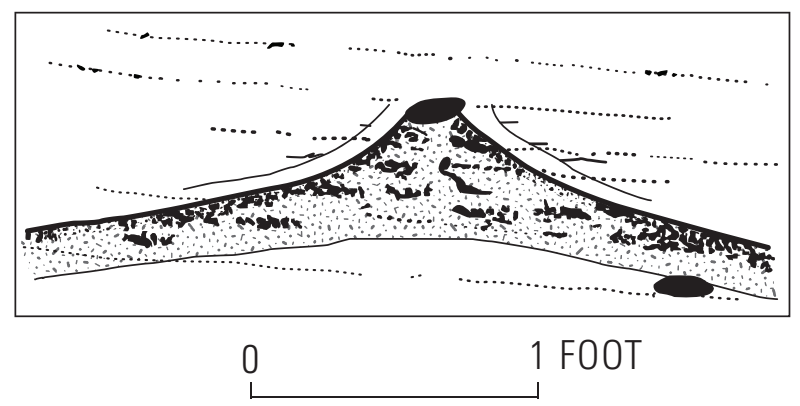

Figure 24. Cross-sectional sketch of a uranium-vanadium ore layer (stippled) in flat-bedded sandstone (bedding in sandstone suggested by nearly horizontal dotted lines); Cougar mine, Lower group of mines. Position and form of the ore layer has been influenced by presence of small fragments of coaly material (black oval-shaped bodies). Thin solid curved lines just above the ore layer on either side of the upper fragment of coaly material are layers of malachite and sparse volborthite. Note how ore layer appears to be draped from the upper coaly fragment whereas shape of the layer is unaffected by the lower coaly fragment. The configuration of the layer indicates encroachment of the introduced solution from above, so that the upper coaly fragment served as an impermeable barrier to introduced solution movement. replaced by ore minerals). Fractures are more enhanced in weathered deposits, suggesting further volume change caused most likely by removal of carbonate. Divergence from concentric layering of carbonate in and near oxidized rolls (Archbold, 1959), in contrast to concentric layering of most elements in the ore roll, described later (p. 47-59), may have resulted from redistribution as a result of weathering. Some roll ore bodies have sharp concave surfaces and diffuse convex margins, as shown in figure 25 , and as illustrated by the large crescent roll near the middle of cross sections $M-M^{\prime}$ and $N-N^{\prime}$ of plate 15 . The dark crescent in sandstone to the right of the ore roll in figure 25 is a "shadow roll" of hydrated iron oxide. Lateral continuity of such rolls with either tabular or roll bodies, both of which have sharp contacts on a continuous surface, indicates their common origin. The roll illustrated in figure 25 is in the west-central part of the Cougar mine; it was extensively sampled for a variety of mineralogical and chemical studies described in later sections (p. 39-44).

Many uranium-vanadium ore rolls show concentric layering parallel to ore surfaces, as shown in figure 25 . The Liesegang ring-like character of the roll in figure 25 , alternating concentric rings, suggests formation at an interface between two fluids. Tyrell (1926, p. 222) described the formation of Liesegang rings as a result of diffusion from one solution into another, through a gel-like substance. Liesegang rings are an indication of diffusion between two fluids, supporting an interface condition, and the suggestion of diffusion through a gel perhaps reflects presence of humicacid gel. Toward the convex side of the roll the concentric layers become less well defined, and at the margin of the roll the abundance of ore minerals diminishes gradually so that ore changes in a diffuse manner into barren rock. 


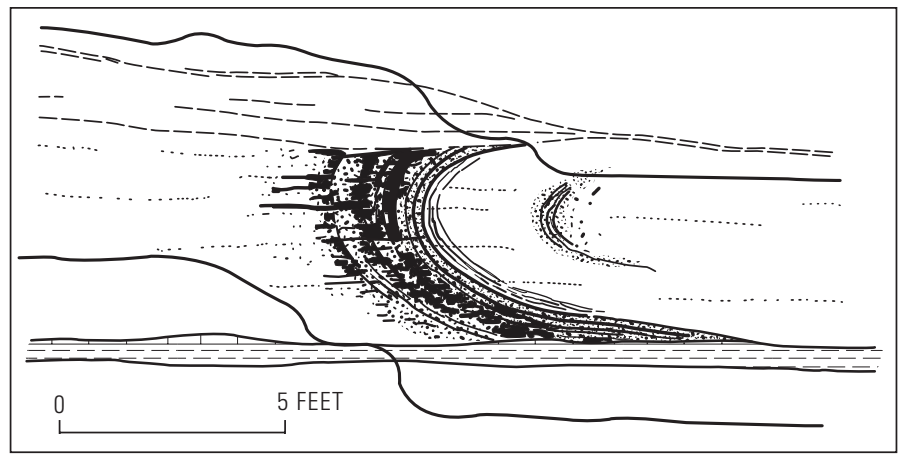

Figure 25. Cross-sectional sketch of an ore roll in the westcentral part of the Cougar mine, showing layering of ore minerals concentric with the concave surface of the roll. Density of stippling and lining within the roll suggests relative concentration of uranium and vanadium minerals. Dark crescent form a few feet right of the concave edge of the roll (a "shadow roll") is hydrated iron oxide, probably oxidized from pyrite. Thin layers ("shadow rings") just right of the roll surface are reddish-brown goethite(?). Nearly horizontal dotted lines indicate bedding in flat-bedded sandstone. Dashes indicate mudstone-claystone layers; mudstone-claystone seams above the roll locally contain abundant detrital carbonaceous material; mudstone layer below the roll contains abundant limonite (after pyrite) where the roll is in contact with the mudstone.

Figure 26 illustrates a compound roll ore body that provides evidence of some of the factors that controlled precipitation of ore minerals. The thin (2-3 ft thick) sandstone layer in which the two merged rolls formed contained two adjacent zones of introduced fluid flow (more or less normal to the cross-section of the compound roll). The zone at the right against which the thicker roll formed was confined between an upper and a lower mudstone layer; the zone of flow was constrained on its left margin by a hump in the lower mudstone layer. The zone of introduced fluid flow at the left against which the thinner roll was deposited was in contact with the upper mudstone layer but not with the lower; it was constrained at its right margin partly by a hook-shaped irregularity in the upper mudstone layer. Flow of introduced solution in both zones may have been simultaneous, inasmuch as the internal textures in the two rolls are merged. Influence of sandstone bedding upon the local intensity of mineralization in the compound roll ore body (fig. 24) is evident where certain cross-beds are seen to be more heavily mineralized. Probably the two zones of fluid flow originated at two separate puncture points, points of access for fluid movement from an overlying sandstone layer into the thin sandstone layer that contains the ore bodies. Although the thin, inner concentric layer of sulfide evident in the roll to the left suggests a possible difference in composition of the introduced fluids forming the two rolls, a possible similar layer of sulfide against the inner surface of the roll to the right may have been unrecognized at the time of examining and sketching the roll.

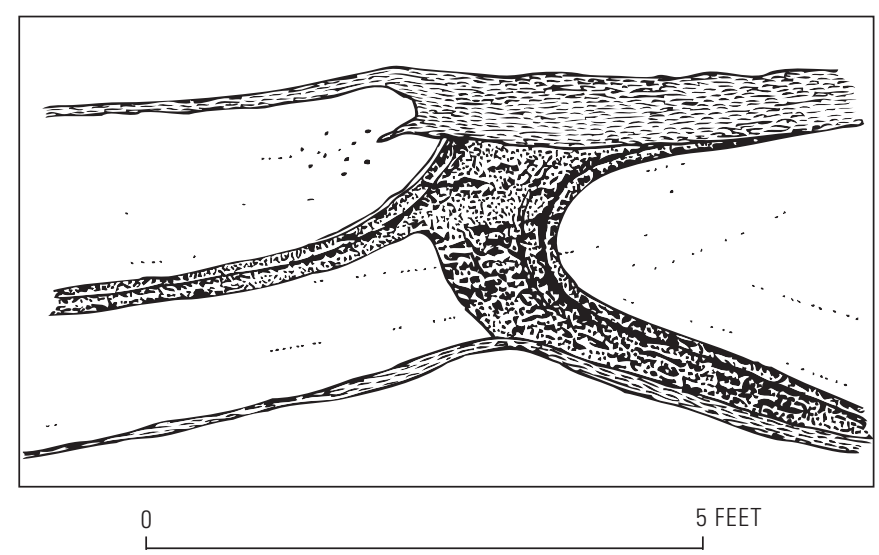

Figure 26. Cross-sectional sketch of a compound roll ore body in the northeast part of the Cougar mine, showing two opposing rolls that are merged at their upper convex margins. Density of stippling and lining within the rolls suggests relative concentrations of uranium and vanadium minerals; note concentric layering of ore minerals near the concave surfaces of the rolls. The thin line adjacent to the upper concave margin of the roll on the left consists of chalcocite and volborthite; specks of volborthite are scattered in barren sandstone above and to the left of the chalcocite-volborthite layer. Sweeping dotted lines suggest bedding in crossbedded sandstone. Dashes indicate mudstone-claystone; mudstone below and against the roll on the right contains "trashy" particles of detrital carbonaceous material.

A remnant of a mined roll ore body mapped in the central part of the Cougar mine (fig. 27) shows local textural variations in uranium-vanadium ore that suggest a control of precipitation of ore minerals related to properties of formation fluid in the host sandstone at the time of mineralization. The roll shown is inferred to have been deposited at an interface between formation water on the right side of the roll and introduced water on the left side of the roll. As interpreted in more detail below, formation water contained humates either in solution or in gel form, derived from the abundant carbonaceous plant material in the sandstone host rocks. The ore textures evident in the roll depicted are in part the result of the character of the host sandstone, but also in part the result of a factor no longer evident in the sandstone. In the upper right part of the roll just below a thin mudstone layer, in structureless weakly cemented sandstone, ore is strongly mottled. (Mottled ore, called "rattlesnake" ore by miners, is a common form in most of the uranium-vanadium deposits in the district.) An example of unoxidized rattlesnake ore from the Sun Cup mine in the Joe Davis Hill-Disappointment Creek group of mines is illustrated in figure 28. Below the weakly cemented layer of sandstone shown in figure 27 , a 1-ft-thick layer of thin-bedded sandstone contains "striped" ore, the stripes of which are discontinuous along bedding. An example of unoxidized striped ore from the Sun Cup mine is illustrated in figure 29. Possibly, irregular precipitation of a humate gel 


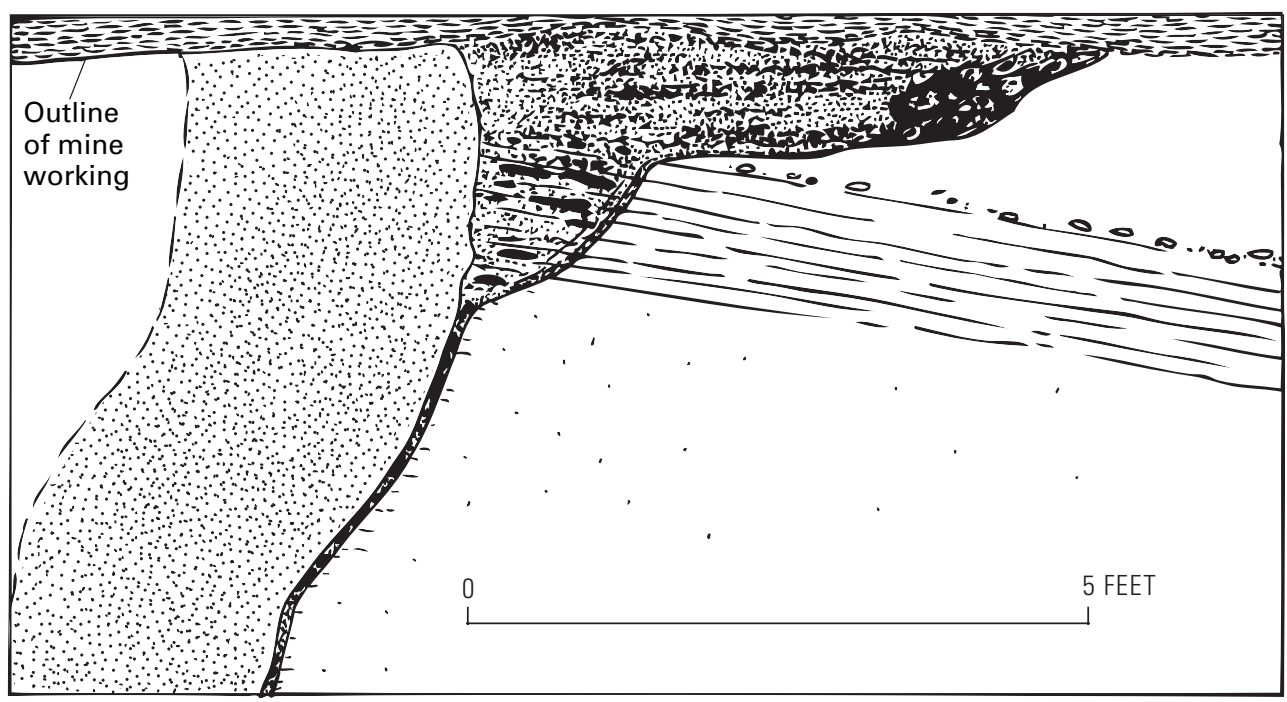

Figure 27. Cross-sectional sketch of a remnant of a roll ore body in the central part of the Cougar mine, showing textural variations related to general bedding characteristics of the host sandstone. The upper right extremity of the roll consists of mottled ("rattlesnake") ore (varied dense stipple) in structureless poorly consolidated sandstone (shown as unpatterned to the right of ore); below this sandstone layer, "striped" ore has developed in thin-bedded sandstone (subhorizontal, closely spaced lines). Note thin selvage of mineralized sandstone against barren massive sandstone below, marking the "outer" (convex) surface of the mined-out roll (lightstippled area shows postulated original form of the roll). Scattered specks in massive sandstone are tiny spots of limonite (after pyrite). Oval shapes at the base of the layer of structureless poorly consolidated sandstone are greenish-gray mudstone pebbles and flakes. Dashed pattern above ore and sandstone is greenish-gray mudstone layer.

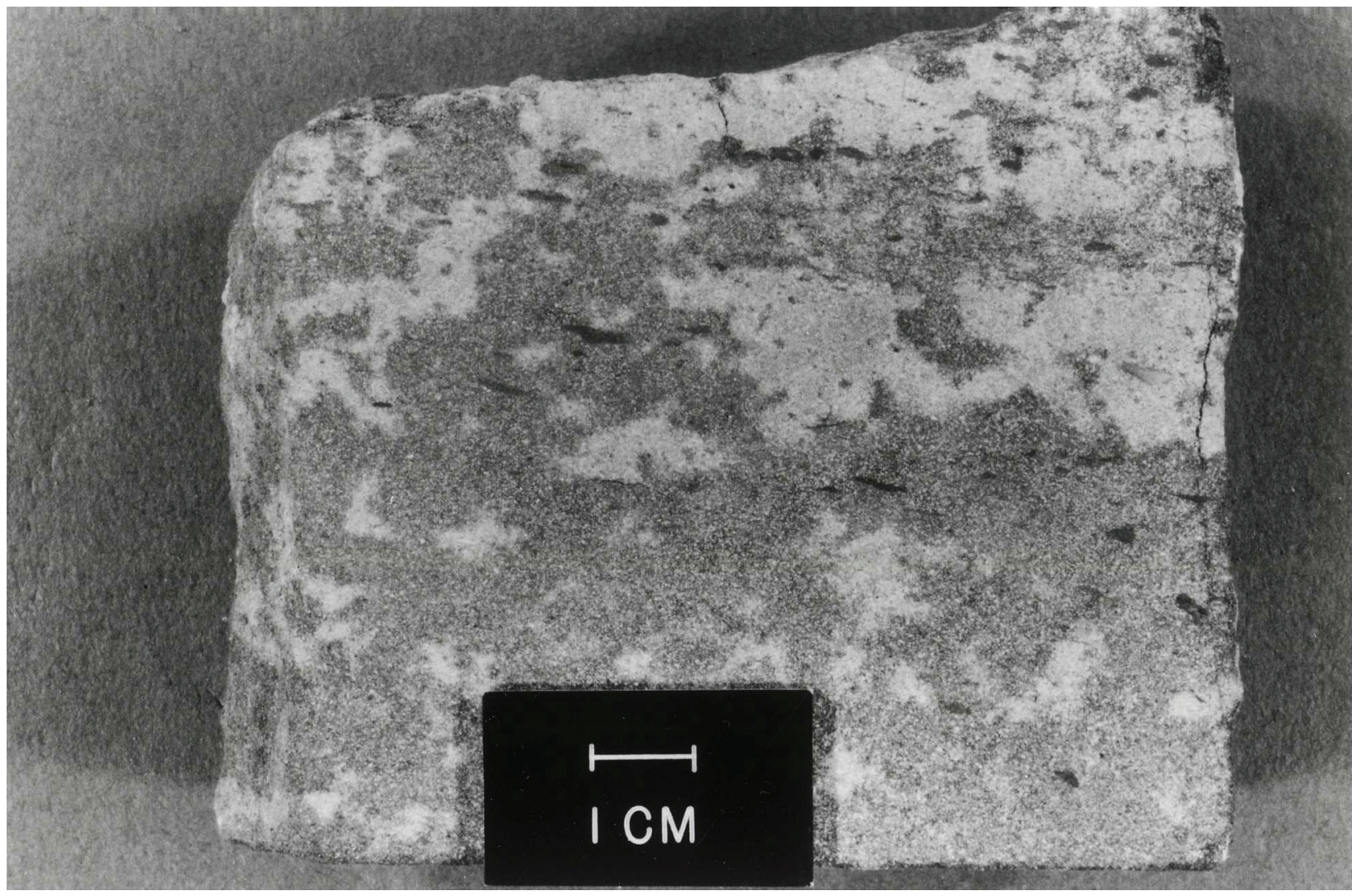

Figure 28. Photograph of "rattlesnake" (mottled) ore from the Sun Cup mine. 


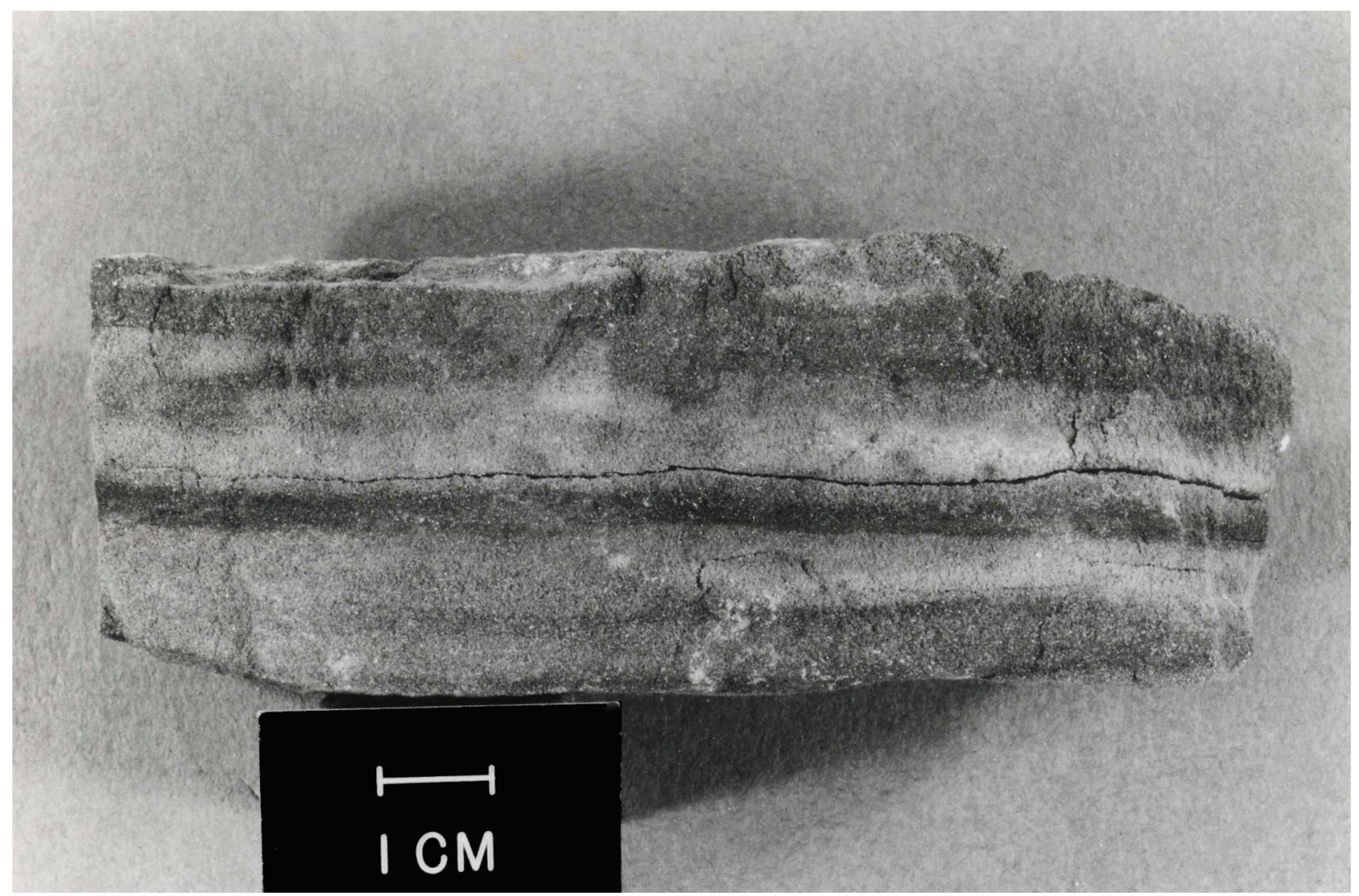

Figure 29. Photograph of "striped" ore from the Sun Cup mine.

as clots in uniformly textured sandstone, and discontinuously along individual beds that show no lateral textural variation, preceded precipitation of ore minerals. Humate gel may have segregated around isolated centers (fragments of carbonaceous plant debris?) as the gel formed. Concentration of uranium minerals was controlled by the distribution of the gel. If uranium was concentrated in the gel, as speculated, interaction with diffusing components from introduced solution caused precipitation of uranium minerals (probably in minutely crystalline form as amorphous uranium oxide- $-\mathrm{UO}_{3}$ ).

A small feature near the margin of a tabular ore layer in the Burro No. 1 mine, Burro group of mines, shown in figure 30 , is consistent with the importance of diffusion in precipitation of ore minerals. The feather edge of a thin tabular ore layer formed against an underlying layer of thin, overlapping claystone diastems that in aggregate constituted an impermeable layer in permeable fine-grained sandstone. A local gap in the claystone barrier, however, allowed downward movement of mineral components derived from introduced fluid, and by interaction with formation water, uraniumvanadium minerals were precipitated in a concentrically layered ovoid protrusion below the claystone horizon. The top of the tabular ore layer in figure 30 was the inferred position of an interface between introduced ore solution above and formation water below. Apparently, the introduced fluid did not move bodily into sandstone below the claystone horizon; instead, ore components diffused through the gap

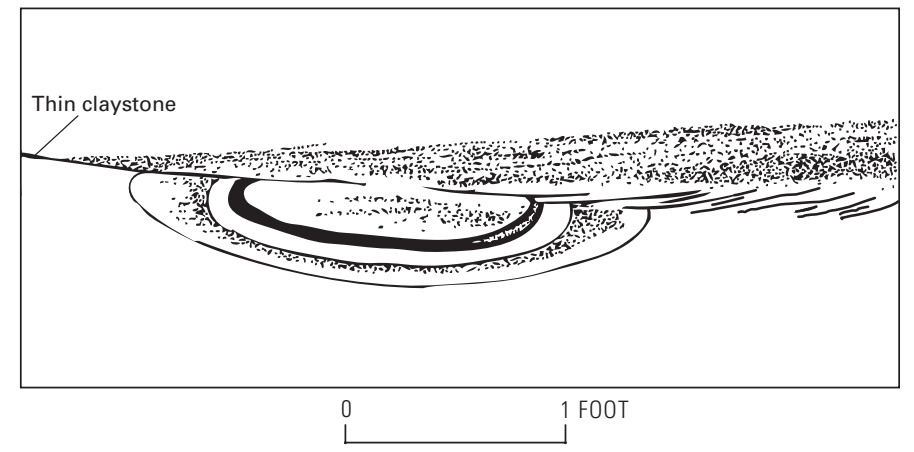

Figure 30. Cross-sectional sketch of Liesegang ringlike layers of uranium and vanadium minerals below a thin tabular ore layer in the Burro No. 1 mine, Burro group of mines. Solid gently curved and overlapping lines are claystone diastems; stippling above claystone horizon depicts uranium and vanadium minerals (intensity suggests relative concentration of ore minerals); concentric curved lines and stippling below claystone horizon show a diffusion-formed concentration of ore minerals; unpatterned area is fine-grained sandstone.

and, with components in formation water (humate gel?), were precipitated in Liesegang ring-like form below the claystone.

The detailed forms and textures just described corroborate influence of permeability on flow of introduced fluid, 
provide further evidence of diffusion during ore deposition, establish the importance of an interface to explain ore body morphology, and introduce the concept of uranium mineral precipitation on local concentrations of humate gel, as well as diffusion of components through humate gel to develop Liesegang ring-like form. In rolls where ring-like forms are faint or absent, humate gel may have been only partly formed or absent.

\section{Mineralogy and Petrography of the Ore Deposits}

My studies of the mineralogy and petrography of the Slick Rock ores and associated rocks, including studies that place mineral species in spatial context within or near ore, generally have been neither comprehensive nor detailed. Nevertheless, several general studies of deposits in the Uravan mineral belt, and specific studies of samples of ores and associated rocks from Slick Rock deposits, allow a reasonable evaluation of the mineralogy and petrography of the deposits. I have made detailed petrographic examination of only a few thin sections of mineralized rocks and evaluation of heavy minerals in and near oxidized ore bodies. In this section, these studies and observations are used to provide more information on physical and chemical characteristics of the uraniumvanadium deposits.

Some ore and gangue minerals have survived oxidation that resulted from near-surface weathering. Most studies of Slick Rock ores have been of oxidized materials. The results of those studies may apply to unoxidized materials because, although "ore minerals" such as some uranium and vanadium minerals have been altered or redistributed by weathering, some such as sulfides and selenides (particularly chalcocite within ore and chalcocite and eucairite in nodules adjacent to the concave surface of rolls), in significant part probably were not.

\section{Moss Back Member Ore Deposits}

Only a few observations on mineralogy of the uraniumvanadium ores in the Moss Back Member of the Chinle Formation in the Slick Rock district are warranted, as only limited studies were made. Carnotite or tyuyamunite are conspicuous in samples of oxidized Moss Back ore collected at or near the surface. By analogy with mineralized rock in the Moss Back in the nearby Lisbon Valley district in Utah, unoxidized or partially oxidized rock probably contains mostly uraninite, vanadian illite-smectite, and montroseite; it contains lesser amounts of coffinite and doloresite (Gruner and others, 1954; Steen and others, 1953; Isachsen and Evensen, 1956, p. 274.)

Minor malachite is evident in some of the oxidized mineralized rock from the Moss Back Member at Slick Rock. Copper-bearing sulfides were not recognized but are likely in unoxidized mineralized rock. Pyrite is moderately abundant in the vicinity of uranium-vanadium ore; some occurs in mineralized rock, some in sandstone near ore, and some in or against mudstone and claystone layers near ore, particularly where these are carbonaceous. Pyrite is common in all forms of carbonized plant material.

Pyrite from mineralized rock collected at the Bullsnake claims in the Dolores River Canyon (just downstream from Horseshoe Bend) and from drill core obtained by Hunt Oil Co. in Summit Canyon (Coleman and Delevaux, 1957, table 2 , locations 148-150) contained only very minor selenium, substantially less than pyrite from mineralized rock in the Salt Wash Member of the Morrison Formation (Coleman and Delevaux, 1957, table 1, locations 26, 27), raising the possibility that mineralization in the Moss Back was chemically distinct from that in the Salt Wash.

\section{Salt Wash Member Ore Deposits}

Slick Rock uranium-vanadium ores in the Salt Wash Member of the Morrison Formation are in a group of Colorado Plateau ores classified by Weeks (1956) as containing a high weight ratio (3:1 to $15: 1)$ of vanadium to uranium, and a greater volume of vanadium minerals than of uranium minerals. Unfortunately there are little quantitative data available on amounts of other minerals present, except for heavy minerals separated from oxidized ores in the Cougar mine, described on p. 39-44.

Unoxidized Salt Wash deposits in the district contain the following ore minerals (that is, minerals characteristic of the ores): uraninite(?), amorphous $\mathrm{UO}_{3}$, coffinite, montroseite, roscoelite, vanadian illite-smectite (vanadian hydromica in earlier terminology), vanadian chlorite (vanadium-bearing chlorite), pyrite, chalcopyrite, galena, sphalerite, ferroselite, clausthalite, naumannite and possibly other sulfides and selenides. Chemical formulas of minerals discussed or mentioned in this report are given in Appendix C. In places ore deposits near the surface but below perched water tables, or just above the water table, and unoxidized ore deposits that have been opened by mining, are partially oxidized. Such ores are referred to commonly as "blue-black" or "corvusite-type" ores. They contain uraninite(?), amorphous $\mathrm{UO}_{3}$, coffinite(?), paramontroseite, corvusite-group minerals, hewettite, vanadian illite-smectite, vanadian chlorite, sulfides, and selenides. Pascoite and native selenium occur locally on mine walls. An example of a deposit that grades from weathered to "corvusitetype" ore is the Strawberry Roan mine (pl. 4). Oxidized deposits (the so-called "carnotite-type" ores), in which many of the primary minerals have been weathered (subjected to oxidation by air and meteoric water), contain carnotite, tyuyamunite, vanadian illite-smectite, and vanadian chlorite. Lesser amounts of hydrated iron oxides (limonite, goethite, lepidocrocite), volborthite, metahewettite, metarossite, azurite, malachite, chalcocite, digenite, bornite, eucairite, clausthalite, naumannite, galena, and chromium-bearing(?) clay have also been recognized in places. Chalcocite, digenite, bornite, eucairite, clausthalite, naumannite, galena, and vanadian-clay minerals probably are in large part residual from primary deposits. A then newly described hypovanadate (not listed in 
Appendix C) in oxidized ore from the Sundown claim in the Slick Rock district was reported by Theadore Botinelly (written commun., 1954). Botinelly and Weeks (1957) presented a mineralogic classification of uranium-vanadium deposits of the Colorado Plateau, including the Salt Wash type.

X-ray diffraction studies by W.H. Raymond of USGS (written commun., 1969) of unoxidized high-grade uraniumvanadium ore from the Sun Cup mine on the Joe Davis HillDisappointment Creek group of mines between Muleshoe and Horseshoe Bends on the Dolores River showed no evidence of uraninite. Similar studies made of unoxidized strongly mineralized rock collected in the Deremo mine about $5 \mathrm{mi}$ west of Egnar (fig. 2) also revealed no evidence of uraninite. The Deremo studies, as reported by H.C. Granger of USGS (oral commun., 1981), were of material collected where no detrital organic material was evident locally. However, Weeks (1956, p. 188) indicated that uranium in unoxidized deposits in the Salt Wash Member (vanadium:uranium range 1:1 to 15:1) "is fixed in uraninite and coffinite and almost without exception is associated with coalified wood or other carbonaceous material" and with pyrite and other sulfides (see also, Weeks and others, 1959, p. 69). Weeks has also stated (written commun., March, 1958) that "most so-called 'black ore' is somewhat oxidized with only traces of $\mathrm{U}+4$ remaining in coffinite in logs and the rest of the uranium is black amorphous UO3." The presence of uraninite in some of the unoxidized ores in the district has not been substantiated but is likely. Partial oxidation of black ore following the opening of mine workings presumably takes place as a result of access of air. Such "blue-black" (corvusite-bearing) ore in the Little Mariel mine northwest of the Cougar mine in the Lower group of claims was coated with pascoite (Weeks and others, 1959). The X-ray diffraction studies by W.H. Raymond of USGS (written commun., 1969) of unoxidized high-grade Salt Wash ore from the Sun Cup mine indicated the presence of montroseite and roscoelite (vanadian illite) and suggested the presence of coffinite. H.C. Granger of USGS (oral commun., 1981) reported that unoxidized mineralized rock from the Deremo mine contained no detectable coffinite, but he pointed out that $\mathrm{x}$-ray diffraction peaks of abundant vanadian chlorites and clays that were present interfered with the coffinite pattern and may have masked its presence. Examination of the material from the Sun Cup mine by P.J. Modreski of USGS (oral commun., 1981) indicated the likely presence of vanadian chlorite (see also, Breit, 1986, p. 66-67).

Sulfides and selenides in oxidized deposits commonly are in compact nodules that appear to have resisted oxidation. Chalcocite, digenite, bornite, eucairite, and chromium-bearing clay (volkonscoite?) may also be present in some unoxidized uranium-vanadium deposits in the Slick Rock district, but they were not recognized there in nodules or otherwise. Some of the unoxidized deposits observed in the course of our studies in the district are copper- and silver-poor deposits, which may account for the fact that chalcocite, digenite, bornite, and eucairite were not identified in those deposits.
Nodules of "chalcocite" (dominantly chalcocite with minor selenides and other sulfides) are common in places in the Cougar mine marginal to oxidized rolls of uranium-vanadium ore. They appear to occur in barren sandstone on only the concave side of rolls, generally just below mudstone layers against which the upper margin of rolls abut (examples are illustrated in figs. 21 and 22). Nodules composed mostly of eucairite (copper-silver selenide), naumannite, and galena are also found on the concave side of rolls in the Cougar mine.

Unusually high amounts of selenium in copper minerals have been recognized by Coleman and Delevaux (1957) in and near an oxidized roll ore body in the Cougar mine. Coleman and Delevaux (1957) also reported a thin selvage of sulfide on the inner surface of a roll located elsewhere in the Uravan mineral belt that contained as much as 18 percent selenium. Selenium content in "chalcocite" and "chalcocite"-digenite in 11 samples from nodules and a thin sulfide-selenide selvage on the concave surface of the Cougar mine roll averaged 1.22 percent, with a high value of 4.93 percent. I believe the location of chalcocite nodules shown on the convex side of a Cougar mine roll (Coleman and Delevaux, 1957, fig. 5) may not be correct; based on consistent occurrences elsewhere in the mine, location is likely on the concave side of the roll. These "chalcocite" nodules contained either an intergrowth of clausthalite and chalcocite surrounded by embayed quartz, an intergrowth of chalcocite, digenite, and minor clausthalite, or an intergrowth of clausthalite and eucairite. Coleman and Delevaux (1957) interpreted the sulfides and selenides as primary minerals, in which local alteration to secondary minerals (for example, azurite and malachite) was evident. Azurite and volborthite occur in oxidized sandstone adjacent to a vanadiumbearing mudstone seam about $0.1 \mathrm{ft}$ thick at the Cougar mine about $300 \mathrm{ft}$ north of the main haulage-way dump (northeast edge of exposed ore deposit). A small pod of (primary?) chalcocite-eucairite in sandstone below the mudstone seam is surrounded by a halo of secondary volborthite about $0.5 \mathrm{ft}$ in diameter.

Gangue minerals that have been introduced or redistributed during formation of the Slick Rock uranium-vanadium deposits are quartz, anatase, barite, and carbonates (mostly calcite; some calcite contains appreciable iron and (or) magnesium; Archbold, 1959). As Archbold (1959), Breit (1986), and Breit and Goldhaber (1995) have shown, carbonate minerals in strata in the Dolores anticline are more magnesium rich than in the Disappointment syncline. Also, in areas of ore deposits, carbonate is more magnesium rich in mineralized rock than in barren rock near ore bodies (Archbold, 1959). Minor authigenic anatase is present in or near some mineralized rock. The ores also contain a substantial residuum of the original detrital minerals (mostly quartz) of the host sandstone (Bowers and Shawe, 1961; Shawe, 1968; 1976a). Detrital black-opaque (iron-titanium-oxide) minerals within ore may have been modified during alteration-mineralization to a mineral similar to rutile (see following section on heavy mineral studies). Minor gypsum in some oxidized ores at Slick Rock is considered to be a product of weathering, by conversion 
(oxidation) of pyrite and reaction with calcite. Keller (1962) described clay minerals (including detrital and diagenic) in the Morrison Formation of the Colorado Plateau.

\section{Petrography of the Salt Wash Member Ore Deposits}

\section{Thin-Section and Heavy-Mineral Studies of Oxidized Cougar Mine Rolls}

Microscopic studies were made of thin sections and heavy mineral grain mounts from samples of uranium-vanadium ores collected in and near oxidized roll ore bodies in the southeastern part of the Cougar mine (figs. 31A, B, and $C$ ).

Mineralogic studies by John Hathaway of USGS, of samples collected by Alice Weeks (USGS, written commun. 1955) from the positions of samples C-29 and C-30 (see fig. $31 A$ ) indicated that the dominant vanadium mineral near the concave side of the roll is vanadian chlorite and the dominant vanadium mineral near the convex side of the roll is vanadian illite-smectite. Hathaway's data form the basis for inferring vanadian-clay species in thin-section studies described below.

Thin sections of samples from within and near the roll illustrated in fig. $31 A$ (samples C-28, 29, 30) include barren sandstone about one foot from the concave surface of the roll (C-28), mineralized sandstone a few inches inside the concave surface of the roll (C-29), and mineralized sandstone a few inches inside the convex margin of the roll (C-30). I earlier reported some results of petrographic studies of sample C-28, and of sample $\mathrm{C}-32$, the latter about $2 \mathrm{ft}$ beyond the convex surface of the roll (Shawe, 1976a, figs. 8 and 5, respectively).

A pen-and-ink drawing of a thin section of part of sample C-28 (Shawe, 1976a, fig. 8), from barren rock on the inferred introduced solution side of the roll, shows euhedral barite crystals interstitial to and penetrating detrital grains of quartz, indicating epigenetic formation of the barite. Euhedral overgrowths of quartz on detrital quartz grains are not evident in this sample. Figure 32 illustrates a thin section from sample C-29, within mineralized rock close to the inferred interface position, where quartz overgrowths occur, but also where interpenetration of adjacent detrital quartz grains shows local dissolution of quartz. Vanadian chlorite as interstitial patches between quartz grains devoid of overgrowths, suggests an early stage of mineralization that replaced illite-smectite in intergranular spaces, and inhibited later precipitation of silica in those zones. A needle-like opaque mineral (probably montroseite) was precipitated on some quartz grains before silica overgrowths covered the grain surfaces. These examples indicate migration of silica in solution following initial mineralization. Figure 33 shows a thin section from sample C-30, in mineralized rock on the convex side of the roll, in which authigenic euhedral crystals of barite fill pore space between quartz grains and in part penetrate quartz grains. Pyrite (now hydrated iron oxide) occurs in barite crystals, suggesting that it was either deposited with barite or subsequently replaced it. Illite-smectite, a major detrital component of Salt Wash mudstone (George Breit, written commun., 2009), fills pore spaces between grains. In another thin section from sample C-30 (fig. 34), on the convex side of the roll, vanadian illitesmectite (vanadium-mineralized illite-smectite) fills most pore space that separates detrital quartz grains, and it is in part replaced by small subhedral to euhedral barite crystals. Quartz grains on the convex side of the roll (fig. 34) do not have quartz overgrowths, suggesting protection that resulted from early pore-filling by diagenetic illite-smectite. A drawing of part of a thin section from sample C-32 (Shawe, 1976a, fig. 5 ), about two feet beyond the convex surface of the roll, shows authigenic overgrowths of silica on quartz grains, and small euhedral crystals of calcite filling the pore space.

Sequence of replacement (paragenesis) in these examples suggests that early vanadian chlorite deposited on quartz grains was in part overgrown by silica derived from solution of detrital quartz grains in barren sandstone on the concave side of the roll. Vanadian chlorite replaced detrital illite-smectite filling pore spaces between quartz grains. Barite (barium sulfate) deposition then took place, followed by iron sulfide deposition. Even with deposition of silica within the roll, at some stage of mineralization (probably early) silica within the roll was also taken into solution.

Partial replacement by chalcocite (probably primary) of detrital quartz in mineralized sandstone is shown in figure 35, part of a thin section from another roll in the Cougar mine. The chalcocite deeply penetrates a detrital quartz grain and entirely replaces other quartz grains. Elsewhere in mineralized rock in a different ore body in the Cougar mine, where quartz grains exhibit quartz overgrowths, chalcocite has filled interstitial space between sand grains, and it has partially replaced quartz overgrowths (fig. 36). The relationship suggests copper sulfide introduction accompanying or following local migration of silica from detrital quartz grains. Chalcocite has been replaced by malachite (as a result of near-surface oxidation) in the example shown in figure 37.

Hydrated iron oxide resulting from weathering (fig. 37) occurs as pseudomorphs of pyrite in uranium-vanadium ore from elsewhere in the Cougar mine. Retention of cubic forms of the original pyrite reflects in-place conversion to hydrated iron oxide. Figure 37 shows the positions of authigenic pyrite deposition in sandstone, crystals of which were extensively corroded by mineralizing fluid which subsequently deposited calcite and a copper mineral (probably chalcocite, now oxidized to copper carbonates) in pore spaces.

Silica redistribution as a result of altering fluid was likely limited by the low solubility of quartz. Solubility may vary only slightly with the presence of chloride or some other ions carried in introduced water, supplemented by dissolution related to clay mineral formation and pressure solution (George Breit, written commun., 2009); therefore evidence of dissolution of detrital quartz grains in barren sandstone near the concave surface of the roll implies passage, laterally along the axis of a roll, of a large volume of warm introduced water to effect the observed dissolution. 
HEAVY MINERAL ANALYSES

(Heavy minerals separated in bromoform, sp. gr. $>2.8$ percentages based on counts of 200 grains in $-150+20$ mesh fraction)

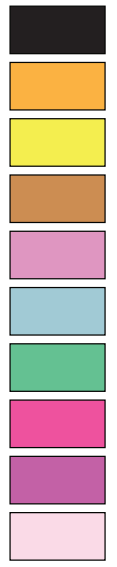

BLACK OPAQUE-Includes hematite,

magnetite and ilmenite

GOETHITE-Probably altered from pyrite

LEUCOXENE-Probably altered from ilmenite

ANATASE

TOURMALINE

ZIRCON

APATITE

BARITE-Recrystallized

GARNET

CARBONATE-Probably dolomite (sp. gr. > 2.8) \begin{tabular}{lllllllllll}
0 & 10 & 20 & 30 & 40 & 50 & 60 & 70 & 80 & 90 & 100 \\
\hline
\end{tabular}

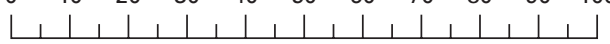

Black opaque

\begin{tabular}{l} 
Goethite \\
\hline Anatase \\
Tourmaline \\
Aircon \\
\hline Apatite \\
\hline Garnet
\end{tabular}

(Rock has $2.4 \% \mathrm{CaCO}_{3}, 0.11 \%$ heavy minerals)

$\begin{array}{lllllllllllllllllll}1 & 1 & 1 & 1 & 1 & 1 & 1 & 1 & 1 & 1 & 1 & 1 & 1 & 1 & 1 & 1 & 1 & 1 & 1\end{array}$

Black opaque

Goethite
Leucoxene

Tourmaline

Zircon

Apatite

Barite

Carbonate

(Rock has $0.3 \% \mathrm{CaCO}_{3}, 0.14 \%$ heavy minerals)

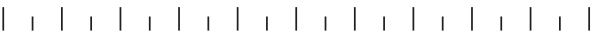

Black opaque

Goethite

Tourmaline

Tircon

Apatite

Barite

(Rock has $1.9 \% \mathrm{CaCO}_{3}, 0.43 \%$ heavy minerals)

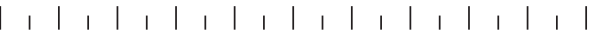

Black opaque

Goethite

Leucoxene

Tourmaline

$\square$ Zircon

Apatite

(Rock has $1.8 \% \mathrm{CaCO}_{3}, 0.17 \%$ heavy minerals)

$\begin{array}{llllllllllllllllllll}1 & \mid & 1 & \mid & 1 & 1 & 1 & \mid & 1 & \mid & 1 & 1 & 1 & 1 & 1 & 1 & 1 & 1 & 1 & 1\end{array}$

Black opaque

Leucoxene Goethite
Zircon

Barite

(Rock has $4.2 \% \mathrm{CaCO}_{3}, 0.60 \%$ heavy minerals)

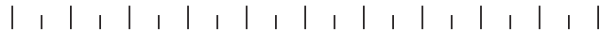

Black opaque

Leucoxene

e

Goethite

Zircon

Barite

Garnet

Carbonate

(Rock has $4.5 \% \mathrm{CaCO}_{3}, 0.44 \%$ heavy minerals)

\section{EXPLANATION}

Mudstone

Abundant "limonite" specks

in massive sandstone

Uranium-Vanadium ore

- Location of heavy-mineral sample

C-30 $\quad$ C-29

$\therefore \mathrm{C}-27$
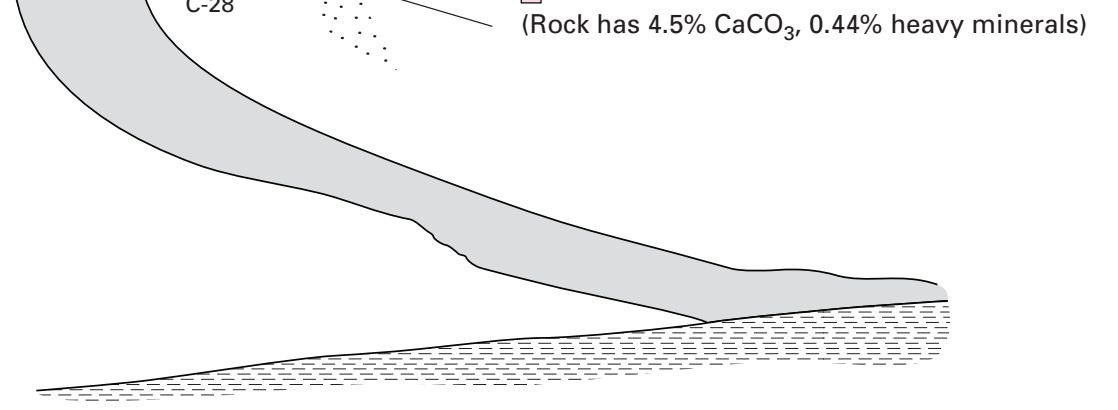

A

Generalized section showing

location of samples

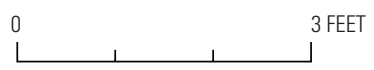

Figure $31 \boldsymbol{A}-\boldsymbol{C}$ (above and following pages). Cross-sectional diagrams of three oxidized roll ore bodies in the Cougar mine showing distributions of heavy minerals, and (fig. 31A) locations of thin sections. Roll $A$ is also illustrated in figure 25. 


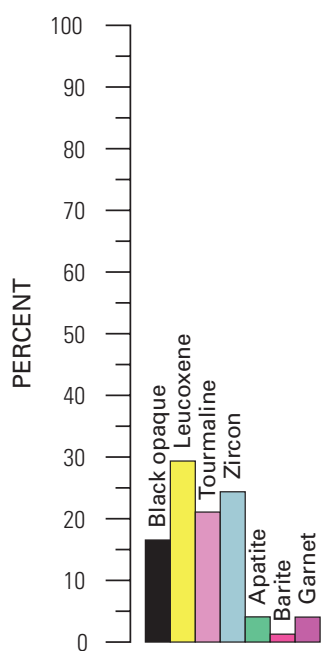

C-13

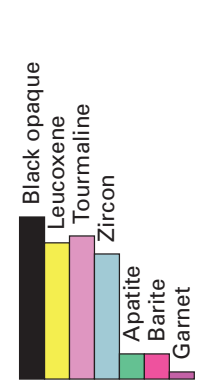

C-12

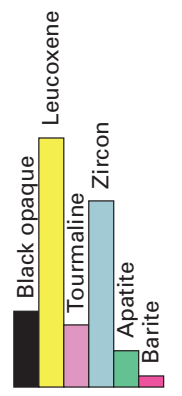

C-11

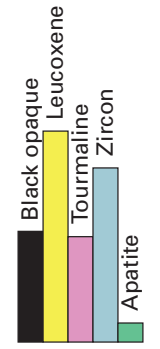

C-10
HEAVY MINERAL ANALYSES

Heavy minerals separated in bromoform, sp. $\mathrm{gr} .>2.8$ percentages based on counts of 200 grains in $-150+20$ mesh fraction)

BLACK OPAQUE-Includes hematite, magnetite, and ilmenite

LEUCOXENE-Probably altered from ilmenite

TOURMALINE

ZIRCON

APATITE

BARITE-Recrystallized

GARNET

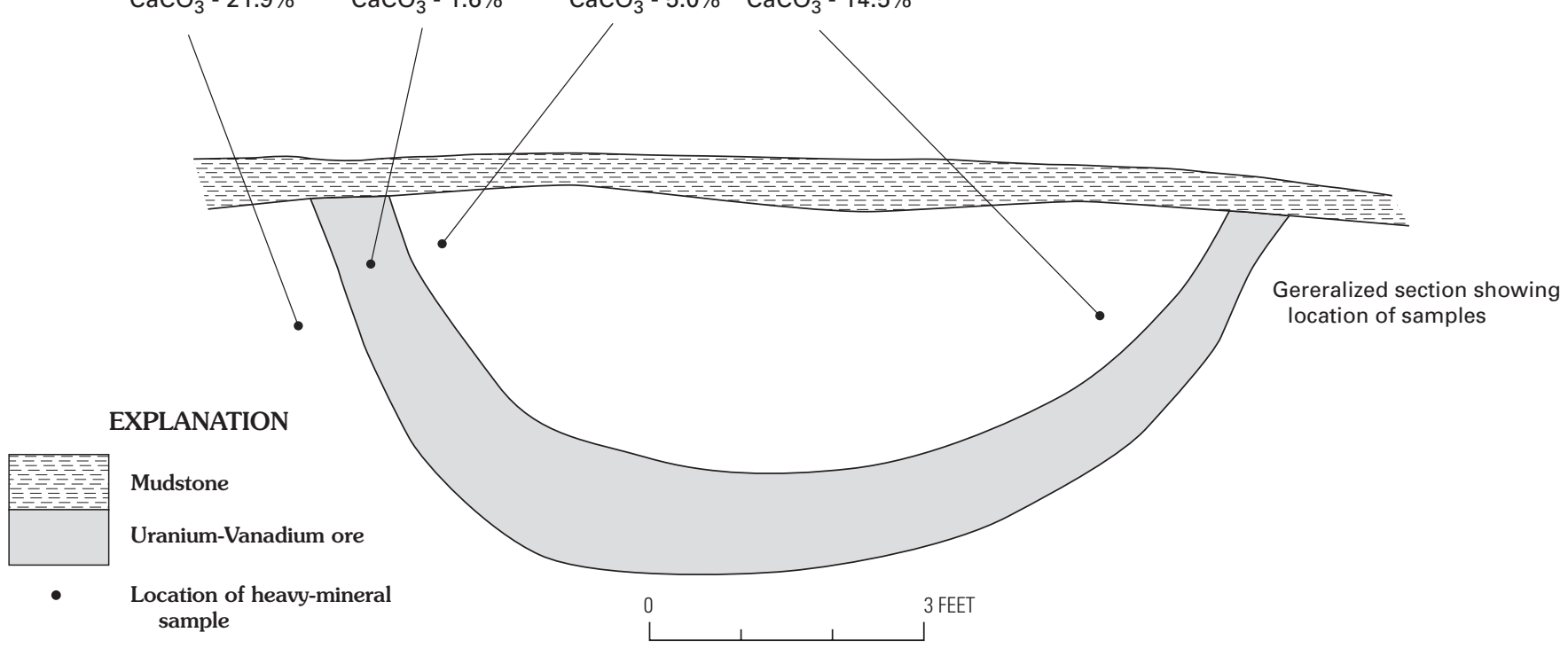

B

Studies of grain mounts of heavy minerals from mineralized and adjacent barren rocks from three oxidized roll ore bodies in the Cougar mine are summarized in figures $31 A, B$, and $C$. Figure $31 A$ illustrates the roll sampled for the thin section studies described above. Heavy minerals constitute two groups, detrital minerals in part modified during the mineralization process, and authigenic minerals likely deposited with ore minerals during mineralization. Detrital minerals include black opaque minerals, tourmaline, zircon, apatite, and garnet. Authigenic minerals are pyrite (altered to hydrated iron oxide as a result of weathering), leucoxene, anatase, rutile(?), barite, calcite, and dolomite. Weathering likely caused some carbonate redistribution. Although absolute amounts of all of the minerals in samples from sites collected in similar positions relative to the roll ore bodies vary from roll to roll, relative amounts of most minerals from similar positions are similar.

Of detrital minerals, black opaque iron-titanium oxides are most abundant within mineralized rock in each of the roll ore bodies, and least abundant in adjacent barren rock on both sides of the roll. Some may have been in part converted to rutile during mineralization. According to studies I made (circa 1957) of mineralized rock from the Teapot Dome mine in the Uravan mineral belt, Bull Canyon district, Montrose County, Colorado, where uranium-vanadium deposits are similar geologically and chemically to those in the Slick Rock district, black opaque minerals that were deposited as detrital iron-titanium oxides, and that still retained detrital form, were converted in part to rutile that contains about one percent combined rare-earth elements, zirconium, and lead. Only partly converted black opaque minerals survived dissolution during mineralization. Such modification of detrital black opaque minerals in Slick Rock ores also may have occurred, accounting for the presence of more black opaque minerals in the ore.

An anomaly is presented by the paucity of black opaques on the convex sides of the rolls (carbon facies; zone of 


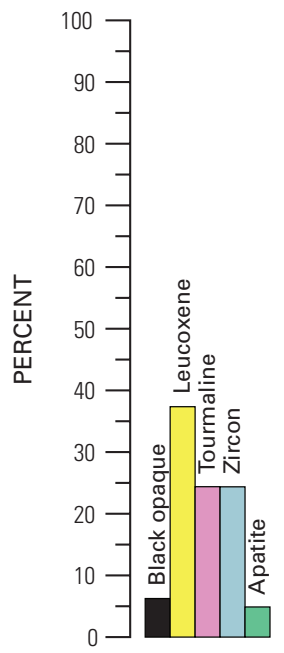

C-14

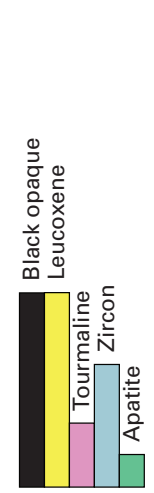

C-15

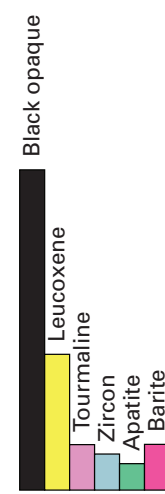

C-16

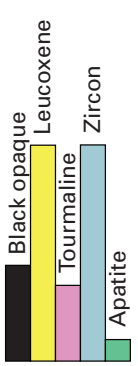

$\mathrm{C}-17$

HEAVY MINERAL ANALYSES

(Heavy minerals separated in bromoform, sp. gr. $>2.8$ percentages based on counts of 200 grains in $-150+20$ mesh fraction)

BLACK OPAQUE-Includes hematite, magnetite, and ilmenite

LEUCOXENE-Probably altered from ilmenite

TOURMALINE

ZIRCON

APATITE

BARITE-Recrystallized

$\mathrm{CaCO}_{3}-3.6 \%$

$$
\mathrm{CaCO}_{3}-3.4 \%
$$

$\mathrm{CaCO}_{3}-5.1 \%$

$\mathrm{CaCO}_{3}-6.2 \%$
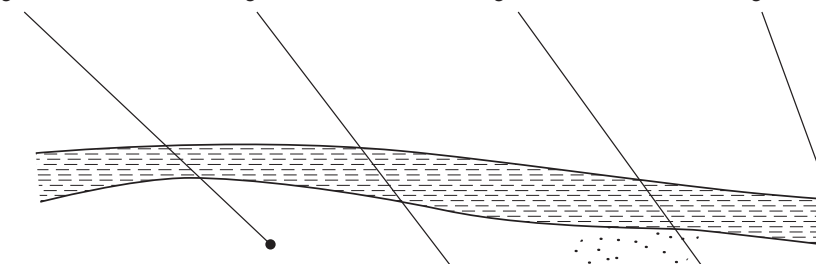

\section{.}



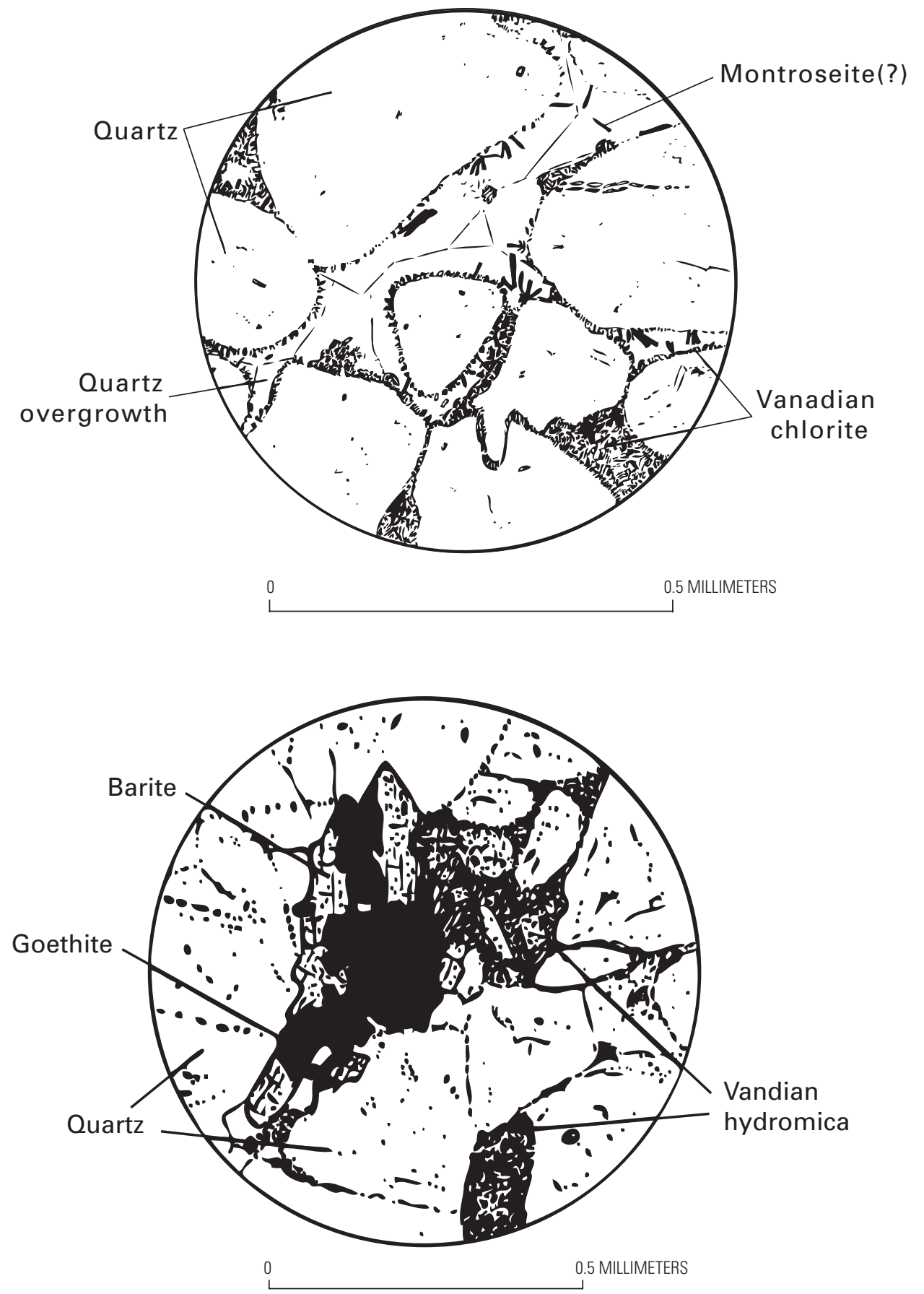

Figure 32. Pen-and-ink drawing of mineralized sandstone; vanadian chlorite rims quartz grains; some quartz grains are sheathed in quartz overgrowths; stylolitic interpenetration of two quartz grains is separated by a thin layer of vanadian chlorite. Black needlelike mineral likely is montroseite. Sample C-29, from concave side of the roll, Cougar mine.

Figure 33. Pen-and-ink drawing of barite replacing quartz in mineralized sandstone; hydrated iron oxide is pseudomorphous after pyrite (note some cubic crystal forms). Sample C-30, from convex side of the roll, Cougar mine.
Distributions of authigenic minerals in and near individual ore bodies are more consistent than are those of detrital minerals. Among authigenic minerals recognized in samples within and near the roll illustrated in figure $31 \mathrm{~A}$, hydrated iron oxide, altered from pyrite is most abundant in barren rock on the inside (concave side) of the roll, almost absent in the position of highest uranium and vanadium concentration in ore near the concave edge, and only moderately abundant near and beyond the convex edge. Concentration of hydrated iron oxide occurs in "shadow rolls" (fig. 25) on the concave side of some roll ore bodies in the Slick Rock district, as well as elsewhere, for example at the Corvusite mine (containing only partly oxidized "blue-black" ore) in Long Park south of Uravan (pers. observation, 1956).

Leucoxene, altered from detrital iron-titanium oxide minerals, is sparse on the concave side of rolls, virtually absent within mineralized rock, and moderately abundant on the convex side of rolls. Absence of leucoxene in uranium-vanadium mineralized rock may indicate that it was converted to rutile during mineralization. Anatase, the end product of sequential recrystalization of leucoxene as indicated in previous studies (Bowers and Shawe, 1961), is present in only very minor 

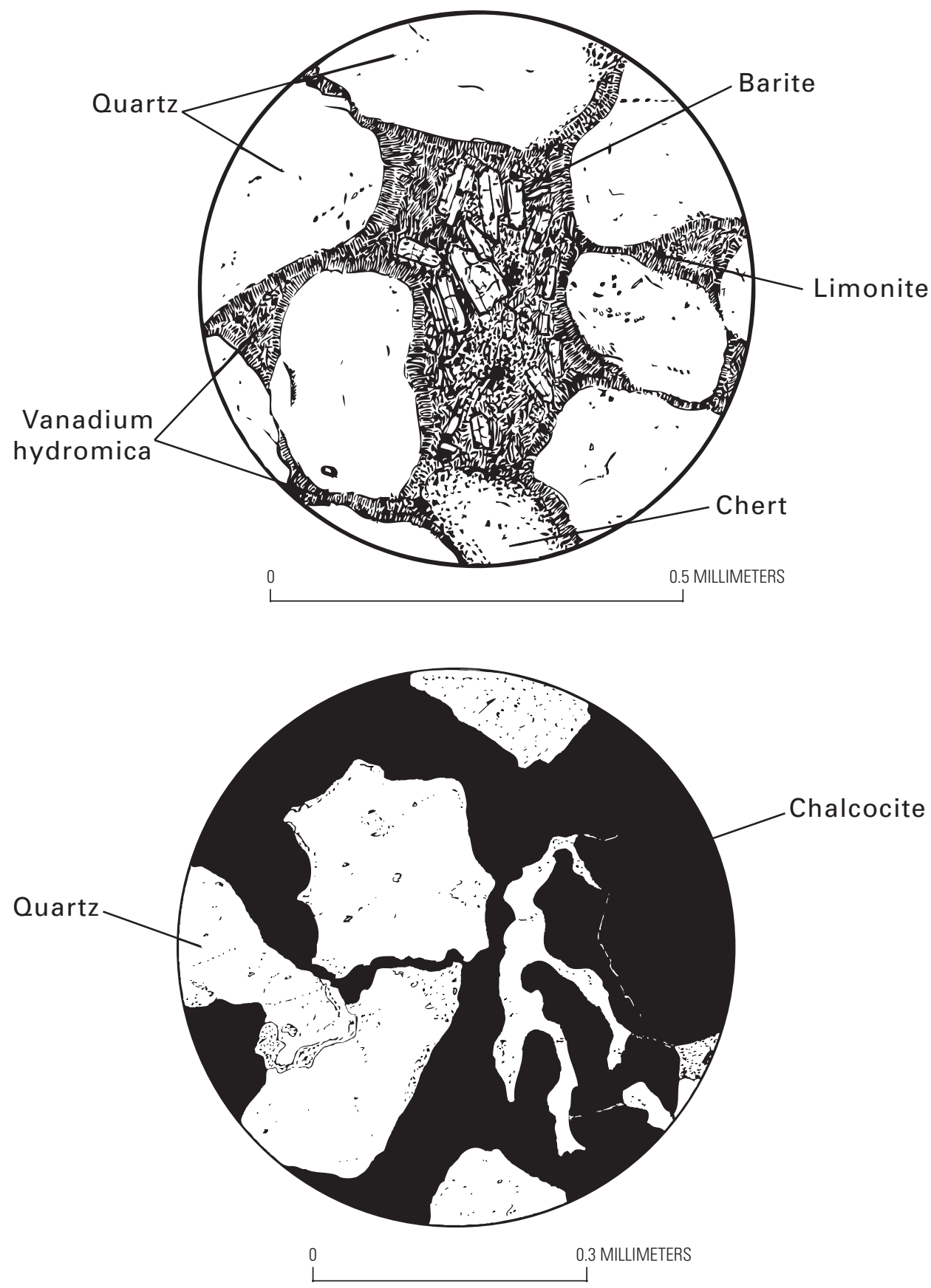

Figure 34. Pen-and-ink drawing of mineralized sandstone; vanadian illite-smectite rims quartz grains and forms an interstitial mat; barite crystals form a cluster in an illitesmectite mat. Sample C-30, from convex side of the roll, Cougar mine.

Figure 35. Pen-and-ink drawing of very fine grained sandstone partly replaced by chalcocite; one quartz grain is deeply embayed by chalcocite. Sample SH-3, Cougar mine. amounts in barren rock about $2 \mathrm{ft}$ beyond the convex edge of rolls. Abundance of detrital minerals zircon, tourmaline, and apatite, as a percentage of the heavy mineral assemblage, in general varies inversely with the abundance of authigenic heavy minerals.

Because of the relative insolubility of barite, its distribution in and near the oxidized rolls in the Cougar mine likely reflects chemical conditions during mineralization that developed the present forms of the ore bodies, rather than by post-mineralizing fluids. Barite constitutes only about 1 percent of the heavy mineral fraction in sample C-27 (in barren sandstone on the concave side of the roll), about 30 percent in sample C-28 (in barren sandstone also on the concave side of the roll but close to ore), about 85 percent in sample C-29 (just inside ore), about 65 percent in sample C-30 (near the convex surface of ore), and about 30-35 percent in samples C-31 and C-32 (in barren sandstone on the convex side of the roll). The distribution of barite therefore is similar to a zonal distribution of several elements in and near the roll, suggesting its deposition along with those elements.

Distribution of minerals in unoxidized ore rolls is unknown, so similarity to that in oxidized bodies is conjectural. However, judged from distribution in the oxidized rolls just described, probably simultaneous deposition of non-ore authigenic minerals and ore minerals established the final (present) geometry of the roll ore body. 

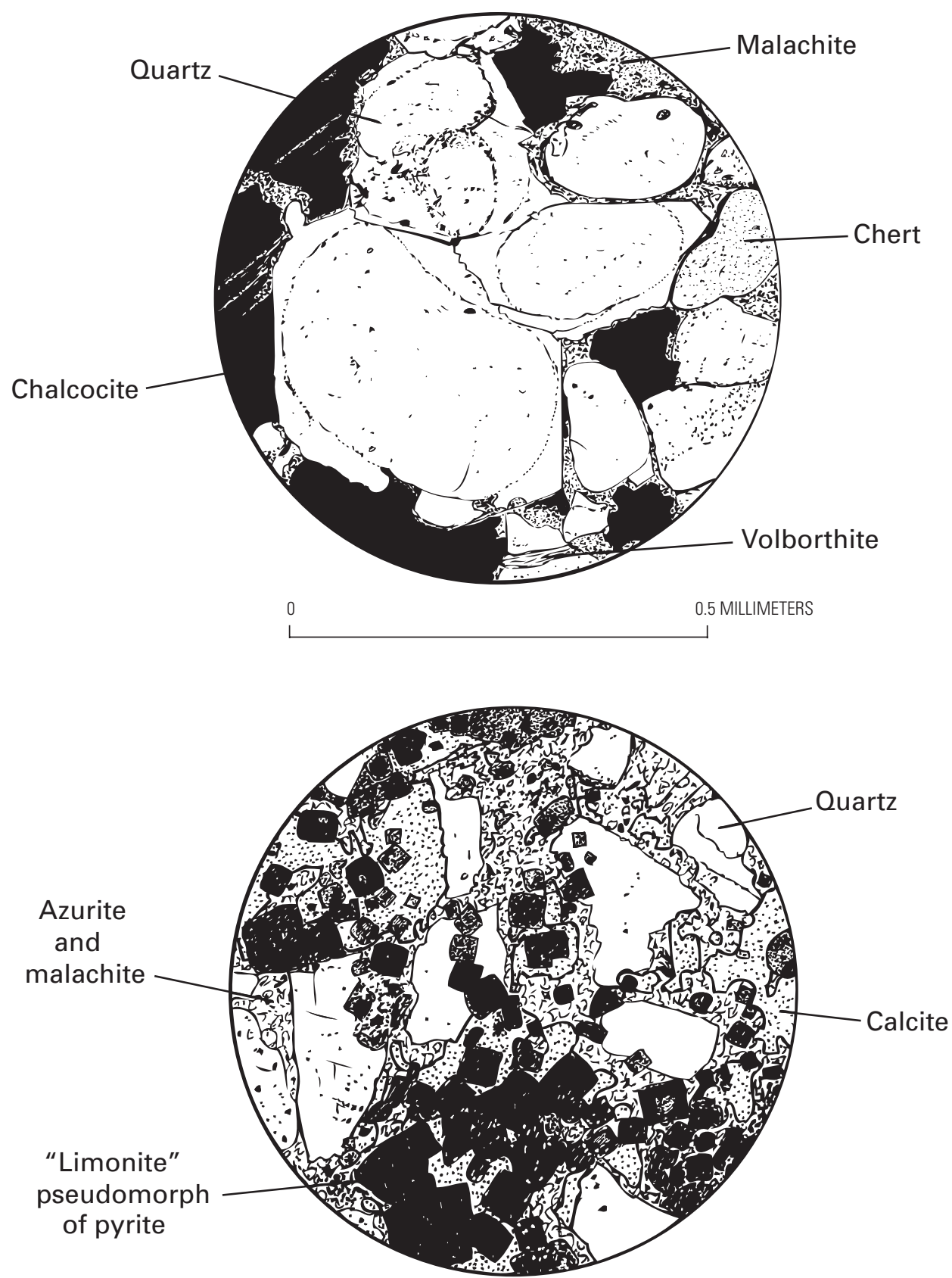

Figure 36. Pen-and-ink drawing of sandstone impregnated and partly replaced by chalcocite; overgrowths on large detrital quartz grain are penetrated by chalcocite to the original surface of the grain; chalcocite is partly altered to bright-green malachite. Sample C-1, Cougar mine
Figure 37. Pen-and-ink drawing of hydrated iron oxide (limonite) pseudomorphs of pyrite in a copperrich replacement veinlet near uranium-vanadium ore in the orebearing sandstone; pyrite formed largely in the matrix between detrital grains, but replaced parts of some grains. Sample C-2A, Cougar mine.
Heavy-Mineral Studies Indicate Relation of Authigenic Anatase and Barite to Uranium-Vanadium Ore Deposits

During alteration of the sandstone strata (to form altered facies), certain authigenic minerals were formed; their distributions and abundances relative to the positions of the ore deposits reflect reaction to introduced ore-forming fluid. These relations corroborate the association of epigenetic alteration with the ore-forming process. Authigenic minerals that indicate most clearly the association are anatase and barite.

Anatase crystals (euhedral, as observed under the microscope) in altered-facies sandstone are the end product of a recrystallization sequence starting with iron-titanium-oxide
0.3 MILLIMETERS (black opaque) detrital grains in red-beds-facies and carbonfacies sandstone, through leucoxene pseudomorphs of the detrital grains, to well-crystallized anatase, in part redistributed. Generally, barite crystals in altered-facies sandstone of the Salt Wash Member (also euhedral as seen under the microscope) resulted from recrystallization and redistribution of interstitial barite that characterizes unaltered red-beds-facies sandstone or generally poorly crystallized (anhedral) barite in carbon-facies sandstone (a caveat regarding carbon facies sandstone is added, below).

Anatase constitutes about 0.003 percent (as volume percent) of total red-beds-facies sandstone, about 0.002 percent of total carbon-facies sandstone, and about 0.004 percent of total 
altered-facies sandstone (in increasing frequency of euhedral form). It makes up about 1 percent of total heavy-mineral fraction of red-beds-facies sandstone, 1.5 percent of total heavy-mineral fraction of carbon-facies sandstone, and 4 percent of total heavy-mineral fraction of altered-facies sandstone (Bowers and Shawe, 1961, table 5). The general increase in anatase content as a percentage of heavy-mineral fractions from red-beds- to carbon- to altered-facies sandstone reflects a combination of diminished content of detrital black opaque iron-titanium-oxide grains as well as progressive conversion of these grains to leucoxene and subsequently to anatase.

Distribution of anatase relative to the uranium-vanadium deposits determined from diamond-drill holes in Disappointment Valley is shown in plate 18. Content of anatase was determined by grain counts (Bowers and Shawe, 1961) of heavy mineral fractions in approximately 40 samples from drill core (Shawe, 1976a, pl. 1)) Anatase is concentrated in a well-defined layer just above the subhhorizontal layer of deposits. Small layers enriched in anatase occur near the base of the ore-bearing sandstone; cause of their localization is not apparent. Anatase likely formed in altering solutions that flowed in a zone above denser, carbonaceous formation water. Sandstone underlying the ore layer was earlier considered to be altered facies rather than carbon facies (Bowers and Shawe, 1961; Shawe, 1976a). However, this inference points out an anomaly in the heavy mineral data (alluded to above) between interpreted altered-facies sandstone above the ore layer and interpreted carbon-facies sandstone below the ore layer. As earlier stated, facies distinctions were based principally on variations in detrital iron-titanium minerals, carbon facies having significantly more such detritals than altered facies. Perhaps relative abundance of euhedral anatase is a more specific indicator of altered-facies sandstone. Also, not considered in the early evaluations (Bowers and Shawe, 1961) was the possibility that formation water (in carbon-facies sandstone) through time may have caused more extensive dissolution locally of the iron-titanium detrital minerals than inferred, so that interpretation of facies on the basis of content of the irontitanium detritals alone may have been oversimplified.

Plate 19 shows the distribution of barite relative to the subhorizontal zone of uranium-vanadium deposits in the orebearing sandstone along one line of diamond-drill holes in Disappointment Valley (as with anatase content, barite content was determined from grain counts of heavy mineral fractions of about 40 samples of drill core from Disappointment Valley; Shawe, 1976a, pl. 1). The zone of ore deposits is surrounded by a halo in which barite is depleted (less than 10 percent of the heavy-mineral fraction of the sandstone compared to higher averages, 12 percent to 29.5 percent, in carbon- and altered-facies sandstone). Much of the remainder of the orebearing sandstone illustrated in plate 19 contains more than 10 percent barite in the heavy-mineral fraction. Recrystallization (redistribution) of barite to increase content in a broad zone throughout much of the sandstone, and depletion of barite in a halo surrounding mineralized sandstone, clearly were related to localization of the ore zone, although chemical factors involved are not evident.

Barite in the Salt Wash Member constitutes about 0.037 percent of red-beds-facies sandstone, about 0.029 percent of carbon-facies sandstone, and about 0.033 percent of alteredfacies sandstone (Bowers and Shawe, 1961). Barite in red-beds-facies sandstone of the Salt Wash Member occurs as an interstitial mineral constituting about 12 percent of the total heavy-mineral fraction of the rock, that in carbon-facies sandstone consists of only partly recrystallized forms constituting about 18 percent of the total heavy-mineral fraction, and that in altered-facies sandstone occurs mostly as generally euhedral (thus, recrystallized or redeposited) crystals constituting about 29.5 percent of the total heavy-mineral fraction (Bowers and Shawe, 1961, table 5). The increase in barite as a percentage of the heavy-mineral fractions from red-beds- to carbon- to altered-facies sandstone is a reflection principally of the destruction (solution removal) of detrital black opaque iron-titanium-oxide minerals. The somewhat higher content of barite in altered-facies sandstone compared to carbon-facies sandstone may be in part due to barite addition to altered facies during alteration.

\section{Chemical Composition of the Uranium-Vanadium Deposits}

\section{District-Wide Distributions of Elements}

Amounts of some metallic elements in uranium-vanadium deposits in the Slick Rock district, as determined by Shoemaker and others (1959), plotted on a map of ore-deposit locations, show distinctive patterns of distribution. This study of the distribution of elements in the Slick Rock district was carried out before the very productive ores of the Deremo mine were known, and hence no data from the Deremo mine were available for that evaluation. It is uncertain whether or not additional data from the Deremo mine would reflect the element patterns suggested by the data of Shoemaker and others (1959). The Deremo mine lies southwest of the Dolores zone and about five miles west of Egnar. It is centered above the southwest projection of the inferred subsurface fault believed related to the surface faults of the northeastsouthwest-crossing zone, and hence it was likely affected by the same fluids involved in deposition of the other Slick Rock ores. The elements are distributed as zones of diminishing concentration centered on the intersection of the Dolores zone of faults and the zone of northeast-trending faults.

Altered-facies sandstone in the Salt Wash is coincident with the intersecting fault systems and the zone of ore deposits (Shawe, and others, 1959, figs. 2, 9; Shawe, 1976a), suggesting a relation between alteration by an introduced fluid and ore deposition. Also, zoning of certain elements relative to the faults implies introduced fluids as the source of the elements. The zoned elements recognized are copper, lead, molybdenum, and nickel. Most conspicuous and perhaps the 
most significant of these is copper (fig. 38). Copper deposits along the extension of the Dolores zone to the northwest in Utah (Breit and Meunier, 1990) indicate that copper deposited with uranium and vanadium in the Slick Rock ores was introduced along the zone. The fault-controlled Cashin copper-silver mine about 25 mi north of Slick Rock along a northeast-trending structure and near the southwest margin of the Paradox collapsed anticline is another example of copper mineralization caused by introduced solutions (MacIntyre, 2004). Further details of the character of the Cashin deposit which indicate a relation to the Slick Rock ores are given in later pages (p. 60-61) describing chemical correlations of ore deposits.

Distribution of lead (fig. 39) is not as well defined as is that of copper (fig. 38), but an area of highest lead values nevertheless is centered on the Dolores zone of faults. Some of the lead (isotopically defined as common lead) in the uranium-vanadium deposits probably was introduced in fluids moving along the zone (some lead in the mineral deposits was generated in place by radioactive decay of uranium; see also the section on lead-isotope data for the Burro No. 3 mine, p. 56). Distribution of molybdenum (fig. 40) is also less well defined than that of copper. Distribution of nickel (fig. 41) is more closely related to faults, as highest concentrations occur closely associated with the northwest-striking faults of the Dolores zone, and local areas of high nickel values lie in the zone of faults that trends northeast.

Uranium and vanadium do not appear to be zoned relative to the fault systems. Lack of copper, lead, molybdenum, and nickel farther beyond areas outlined on figures 38, 39, 40, and 41 suggests depletion of the dissolved metals with spread of mineralizing fluids, such that distal uranium-vanadium deposits contained negligible amounts of the four metals.

Lateral distribution of copper within an ore deposit has been evaluated only in the Cougar mine. Plate 20 shows estimated abundances of copper minerals, principally secondary minerals including malachite, azurite, and volborthite, throughout the Cougar mine. Also noted locally in zones of abundant copper were nodules of sulfides such as chalcocite, bornite, chalcopyrite, and the selenide eucairite. As plate 20 indicates, copper appears to be randomly distributed within the deposit. Because uranium and vanadium occur throughout the Cougar deposit, controls on precipitation of copper, at least in major part, probably were different from those that induced precipitation of uranium and vanadium. Local accumulations of iron sulfide, formed earlier, and diagenetically, at relatively shallow depth by bacterial sulfate reduction along with decay of local concentrations of carbonaceous materials (Breit, 1986), may have triggered local deposition of copper as various sulfides and selenides.

\section{Distribution of Elements In and Near a Roll in the Burro No. 7 Mine}

Patterns of lateral distribution of most elements throughout an individual deposit such as the Cougar mine (except for copper, as just described) were not evaluated for lack of data. However, several elements are zoned within individual ore bodies. Zoning is best displayed in roll ore bodies, but it also is evident in tabular ore bodies (Shawe, 1966).

The chemistry of only one ore body in the Slick Rock district, an unoxidized (unweathered) roll in the Burro No. 7 mine, has been studied in detail. Data from the Burro No. 7 roll ore body are considered significant because of the simplicity of the local lithologic environment. Fine-grained sandstone in which the roll is formed is generally homogeneous, and thus not likely to have caused irregular lateral diffusion of elements between the interfaced fluids. Similarly, the mudstone layers above and below the ore roll appear homogeneous internally, and lateral chemical differences in the layers therefore resulted from contrasting effects of adjacent formation water or introduced fluid.

Samples collected in and near the ore roll in the Burro No. 7 mine in the late 1950s by personnel of Union Carbide Corp. under the direction of John Motica were analyzed by USGS for several chemical components. Analyses were by a variety of chemical methods, including semiquantitative-spectrographic analyses. Results are published here with permission of Union Carbide Corp. (Note: These same samples were analyzed and studied by Rosholt and others, 1965a, and Rosholt and others, 1965b for uranium-, thorium-, and protactinium-isotope compositions; see later sections thereon, p. 56). Sixteen samples were collected from ore and adjacent sandstone and mudstone, as illustrated in figures $42 A-M$. Even though sample coverage is sparse in much of the roll and surrounding rocks, samples from similar positions relative to the concave surface (that is, they occur in zones concentric with the concave surface) have similar compositions, suggesting the validity of inferred zonation (Shawe, 1966). Minor variations in content of some components in different parts of a concentric zone likely are not significant because variations between different zones are much greater.

For convenience in the following discussion, samples of sandstone are described as mineralized and "unmineralized" or "barren." The two latter terms are not precise, however, because minerals that characterize the ore body may be present in minor or trace amounts in unmineralized or barren sandstone. Some elements may be present in unmineralized or barren sandstone in significant amounts, but are not within mineralized rock that is mined as ore. (Also, see earlier discussion of "mineralized" and "ore," p. 16, and the section on mineralogy and petrography of the ores, p. 37.)

Thirteen components of the analyzed samples of mineralized and adjacent barren rocks in and near the Burro No. 7 ore roll show distinctive distributions, as illustrated in figures $42 A-M$. These components are uranium (U), vanadium oxide $\left(\mathrm{V}_{2} \mathrm{O}_{5}\right)$, iron $(\mathrm{Fe})$, titanium $(\mathrm{Ti})$, chromium $(\mathrm{Cr})$, silver $(\mathrm{Ag})$, lead $(\mathrm{Pb})$, molybdenum $(\mathrm{Mo})$, selenium $(\mathrm{Se})$, copper $(\mathrm{Cu})$, sulfur $(\mathrm{S})$, zinc $(\mathrm{Zn})$, and barium $(\mathrm{Ba})$. Cadmium distribution is similar to that of zinc because of its close geochemical association with zinc, and it is not illustrated. Determined elements that are not illustrated (aluminum, boron, strontium, 


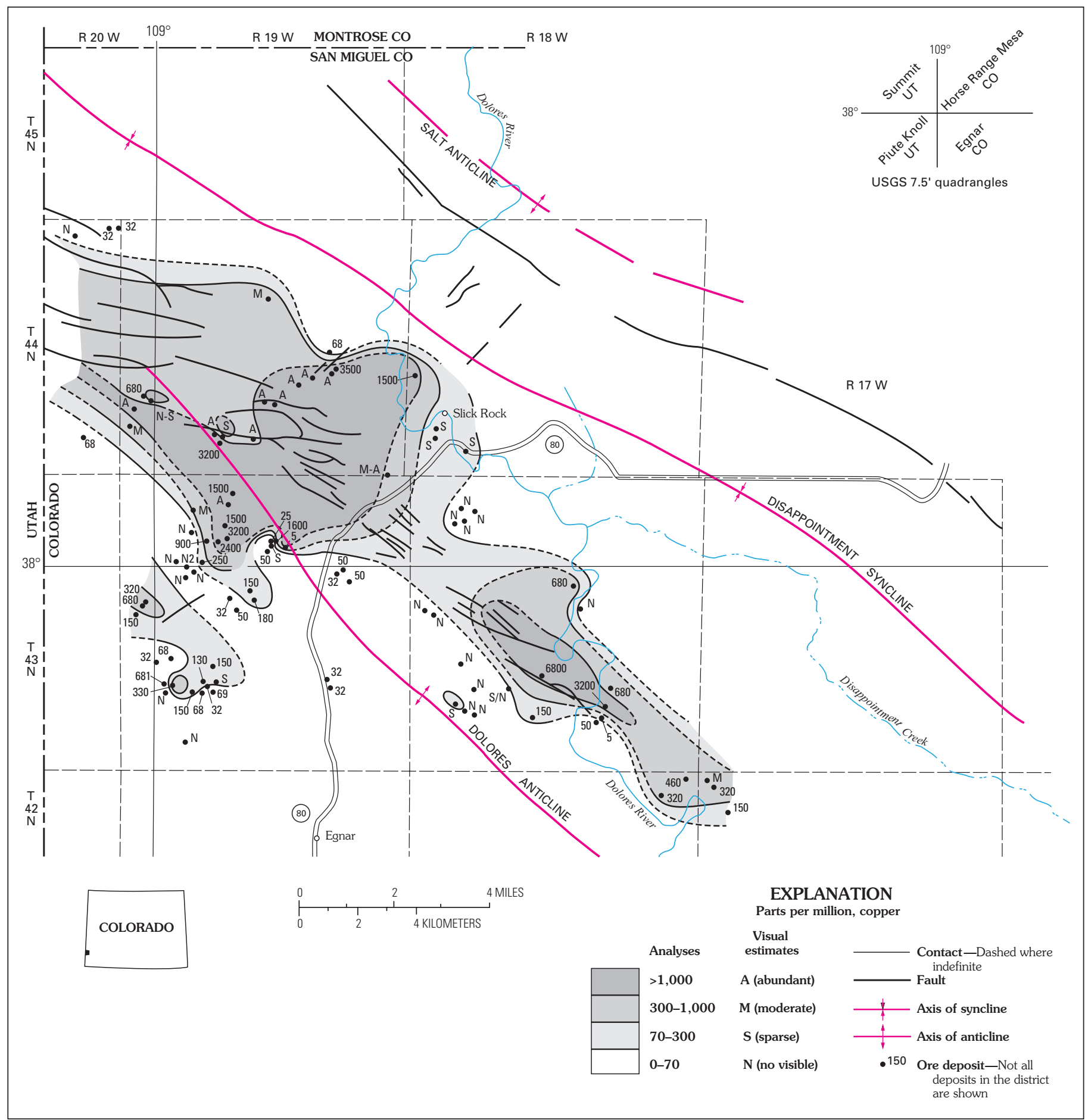

Figure 38. Map of the northern part of the Slick Rock district showing major structural features and amount of copper in uraniumvanadium deposits.

potassium, sodium, calcium, and magnesium) reflect in part alterations or distributions of gangue minerals (authigenic minerals and detrital framework grains). Such alterations and distributions are uncertainly related to the inferred chemical character of the two interfaced solutions at which the deposits formed.

Uranium and vanadium in the Burro No. 7 roll ore body, as seen in figures $42 A$ and $42 B$, have somewhat similar distributions. Both elements are most abundant near the concave surface of the roll (3.10 percent $\mathrm{U}$ and 7.27 percent $\mathrm{V}_{2} \mathrm{O}_{5}$ ) and content is abruptly very low immediately into barren sandstone on the concave side of the roll. Values for both elements generally decrease progressively from the enriched zone near the concave surface of the roll to the convex side of the roll. However, uranium is slightly enriched in barren sandstone on the convex side of the roll and vanadium is not. Effectiveness 


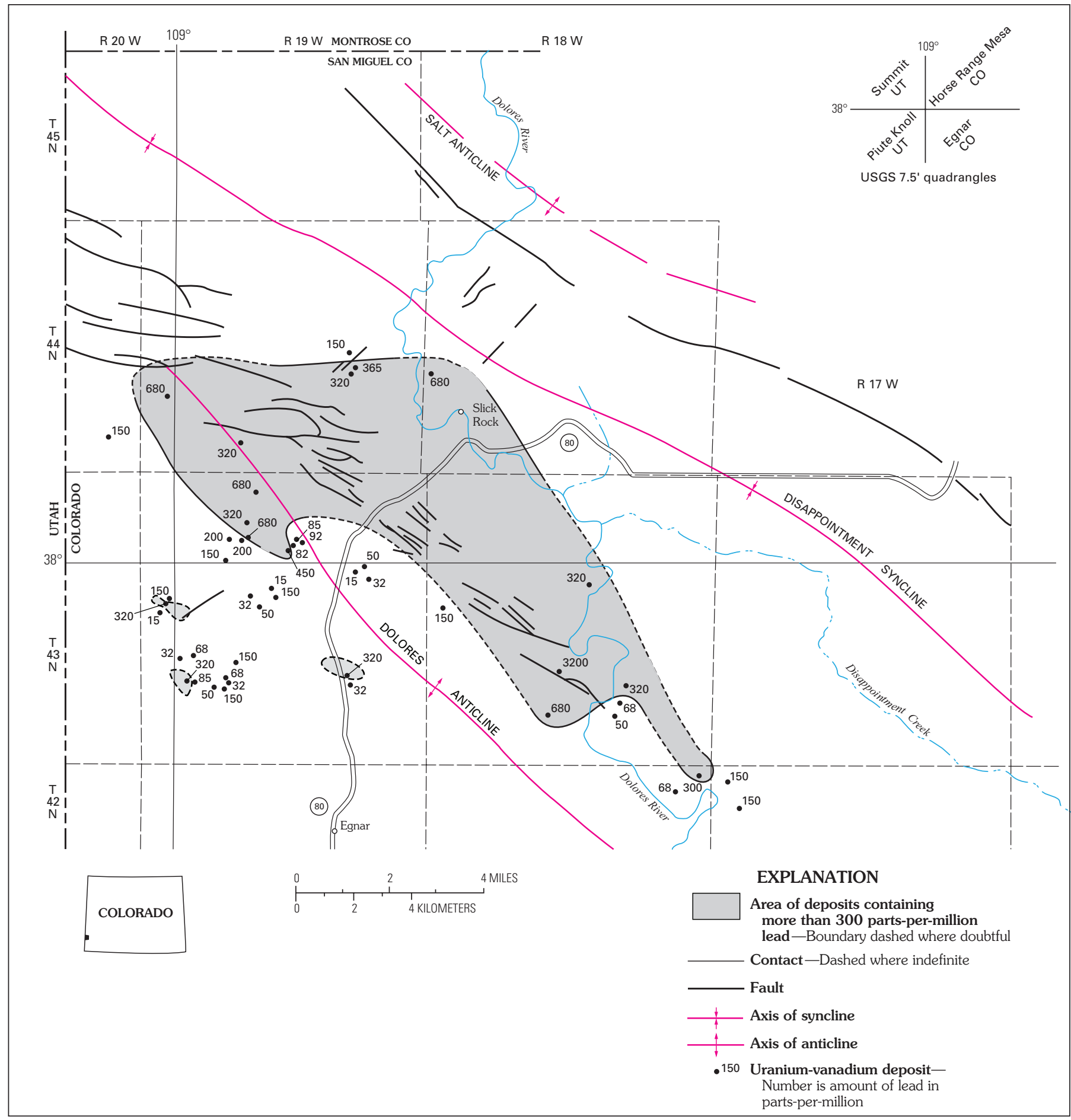

Figure 39. Map of the northern part of the Slick Rock district showing major structural features and amount of lead in uraniumvanadium deposits.

of the mechanism of precipitation of uranium and vanadium apparently was greatest (steepest chemical gradient) at the inferred interface between introduced fluid (concave surface) and formation water (on the convex side), decreasing farther into formation water. High amounts of uranium and vanadium are also evident in mudstone layers above and below the roll, especially extending laterally from the roll on its concave side.
Vanadium content of the mudstone on the concave side of the roll compared to its content in the roll is proportionally much higher than uranium content of mudstone on the concave side of the roll compared to its content in the roll. This relation may be attributable to ready reception of vanadium into the structure of clays in the mudstone layers (Breit, 1986, p. 38). 


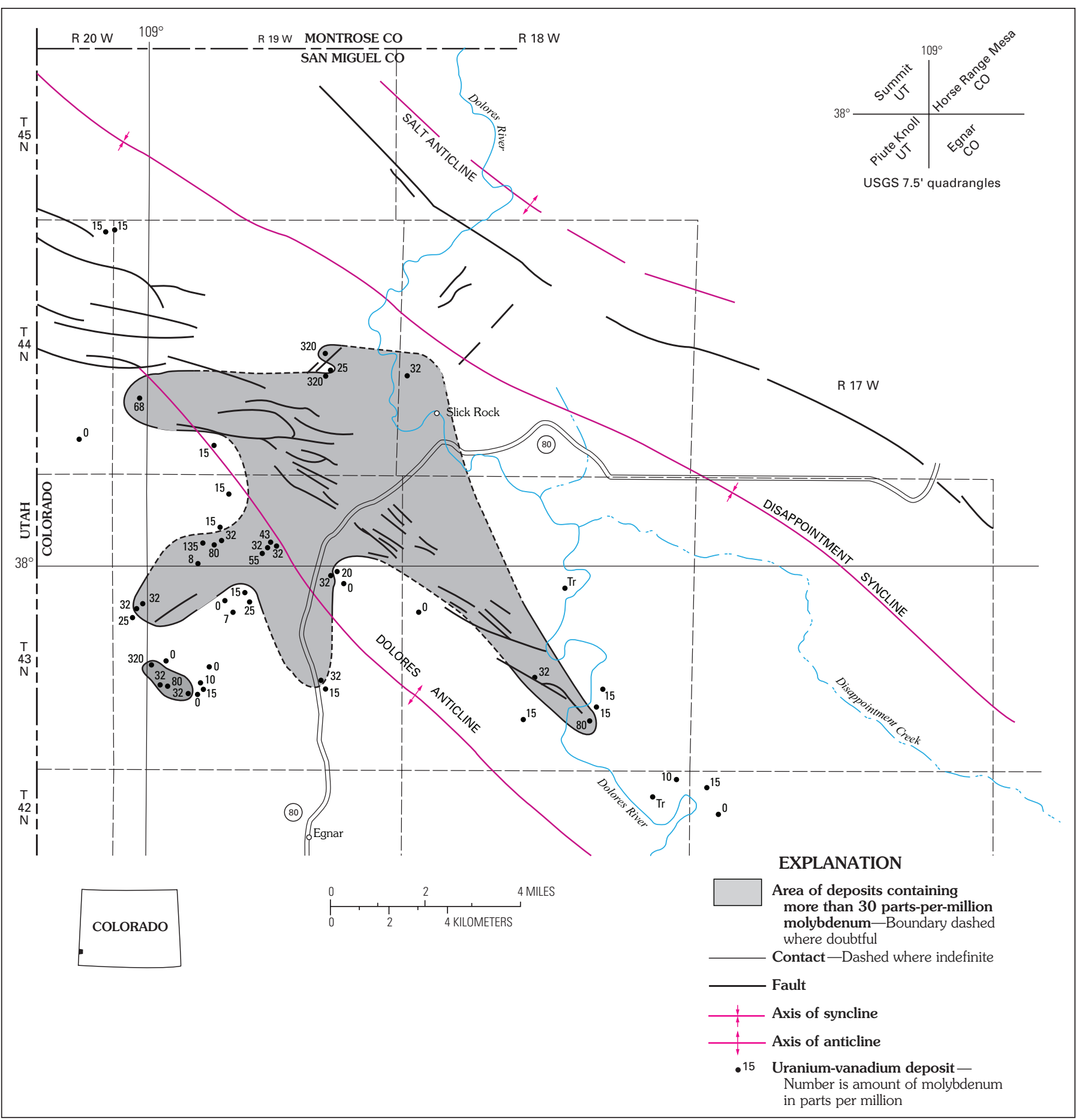

Figure 40. Map of the northern part of the Slick Rock district showing major structural features and amount of molybdenum in uraniumvanadium deposits.

Rosholt and others, (1965a), in a study of uranium isotopes of the same Burro No. 7 roll samples stated that there is no correlation between the content of uranium and vanadium amongst the several samples, indicating to them that "there is no definite evidence showing that vanadium inhibits the preferential leaching of $\left(\mathrm{U}^{234}\right)$ from uranium ore as had been presumed..." Significance of this relation will be discussed later in the section on lead isotopes (p. 60). Lack of correlation between uranium and vanadium in different samples suggests that uranium and vanadium were precipitated in part by different chemical factors.

Several elements in addition to iron (fig. $42 C$ ), including titanium (fig. 42D), chromium (fig. 42E), silver (fig. $42 F$ ), lead (fig. 42G), molybdenum (fig. 42H), and selenium (fig. $42 I$ ), like uranium and vanadium, are most abundant at or near the concave surface of the roll. With these elements, 


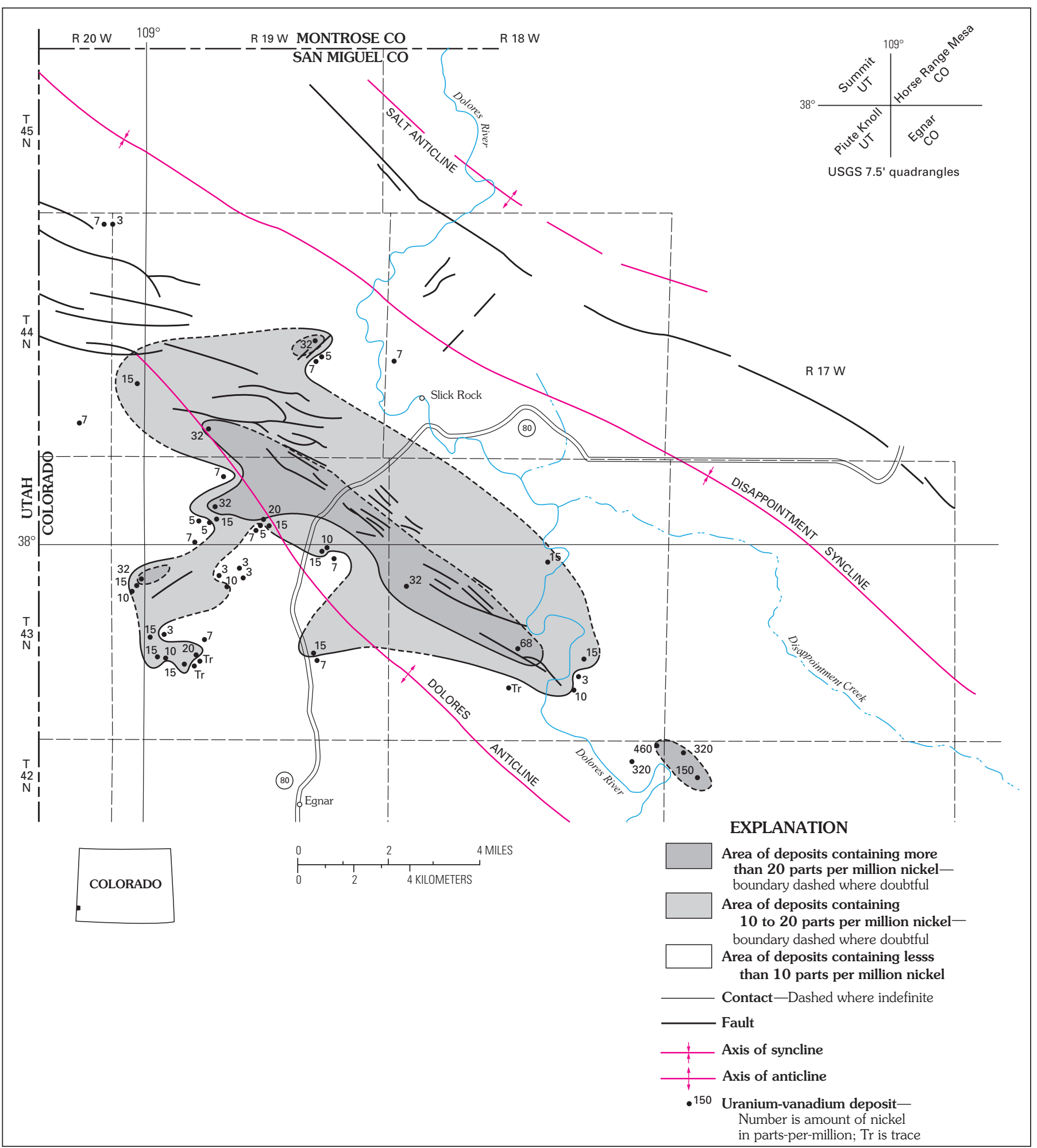

Figure 41. Map of the northern part of the Slick Rock district showing major structural features and amount of nickel in uraniumvanadium deposits.

enrichment extends into mudstone layers adjacent to the roll. Although mudstone likely was saturated with formation water capable of precipitating the metals, mudstone above the formation-water zone in sandstone contains less of the metals than mudstone above the introduced-fluid zone in sandstone.
The higher content of all of these elements (except uranium) in mudstone above the zone of introduced fluid, that is, spatially removed from contact with the zone of formation water, suggests their source was introduced water. 


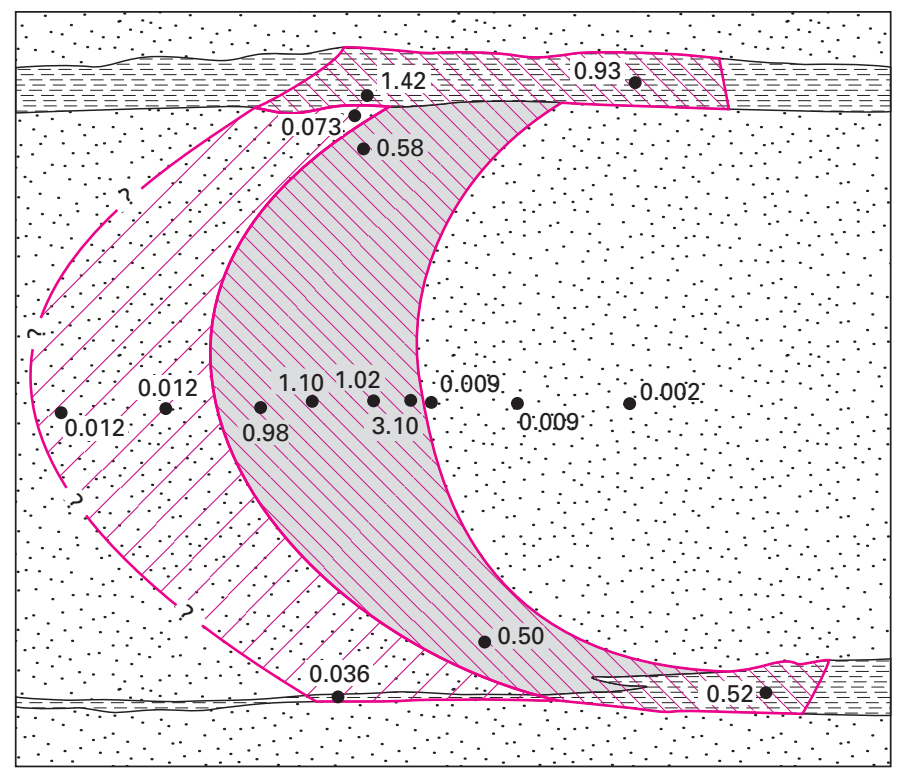

A

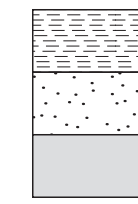

\section{EXPLANATION}

ELEMENT DISTRIBUTION

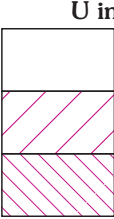

- 0.52 Sample point and value
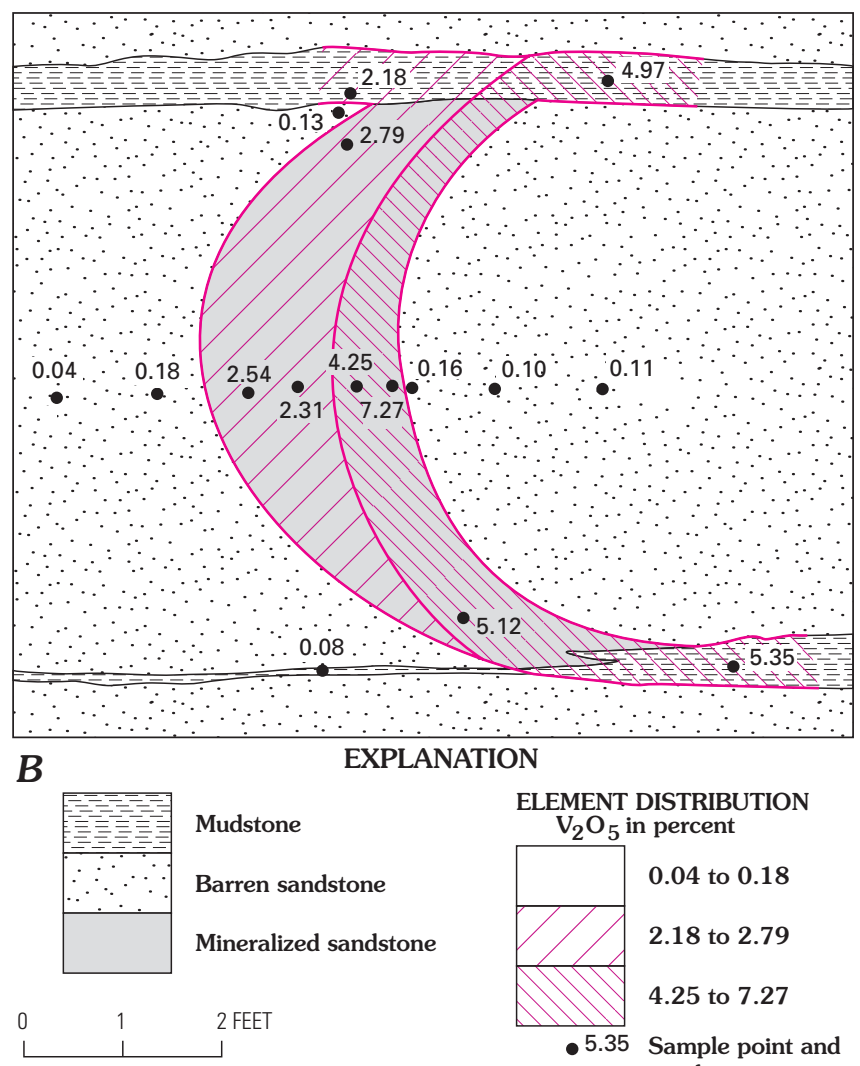

\section{ELEMENT DISTRIBUTION}

$\mathrm{V}_{2} \mathrm{O}_{5}$ in percent

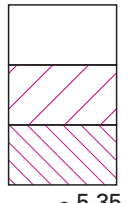

0.04 to 0.18

2.18 to 2.79

4.25 to 7.27

Sample point and value

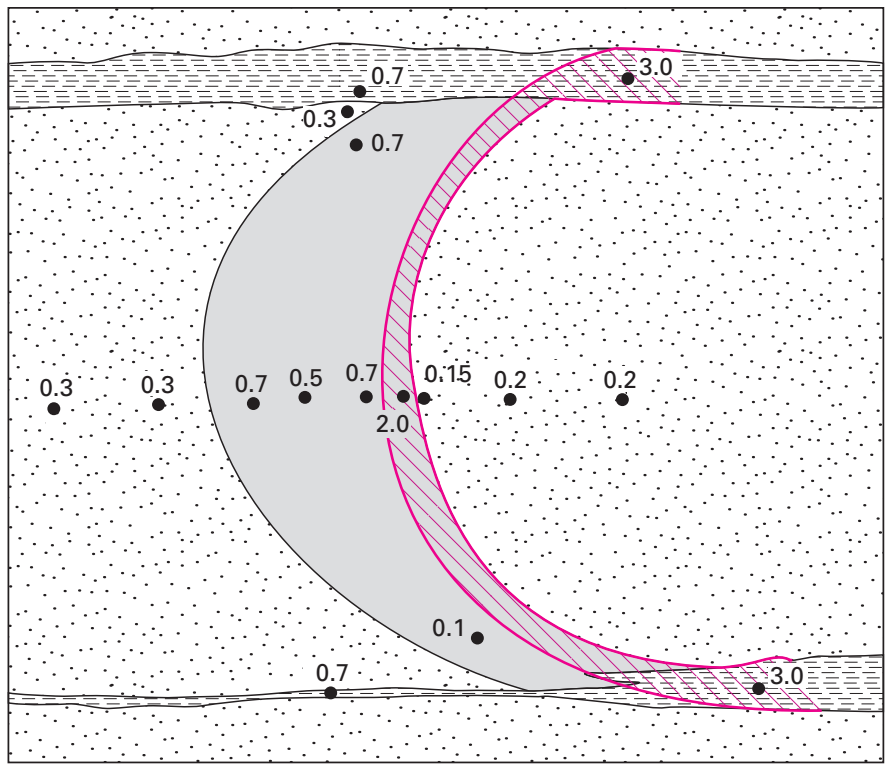

C

EXPLANATION

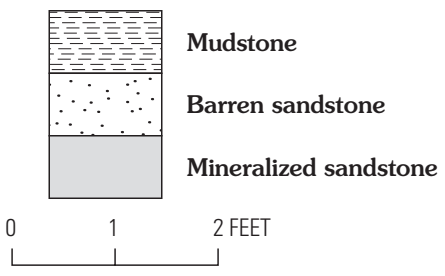

ELEMENT DISTRIBUTION

$\mathrm{Fe}$ in percent

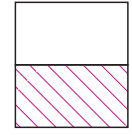

0.1 to 0.7

2.0 to 3.0

- 3.0 Sample point and

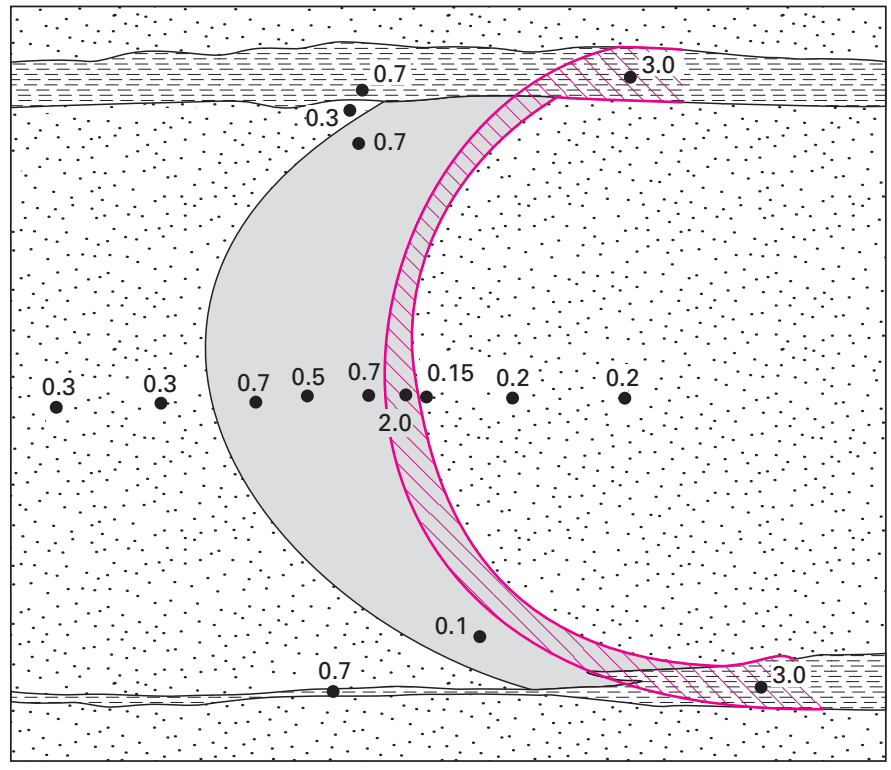

D

EXPLANATION

ELEMENT DISTRIBUTION

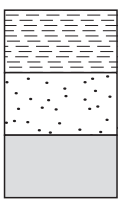

Mudstone

$\mathrm{Ti}$ in percent

Barren sandstone

Mineralized sandstone

2 FEET

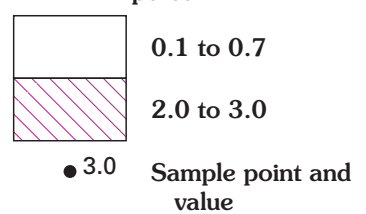

Figure $42(\boldsymbol{A}-\boldsymbol{M})$. Diagrams showing inferred distributions of elements in an unoxidized ore roll in the Burro No. 7 mine: $A$, uranium; $B$, vanadium oxide; $C$, iron; $D$, titanium; $E$, chromium; $F$, silver; $G$, lead; $H$, molybdenum; $I$, selenium; $J$, copper; $K$, sulfur; $L$, zinc; and $M$, barium. 


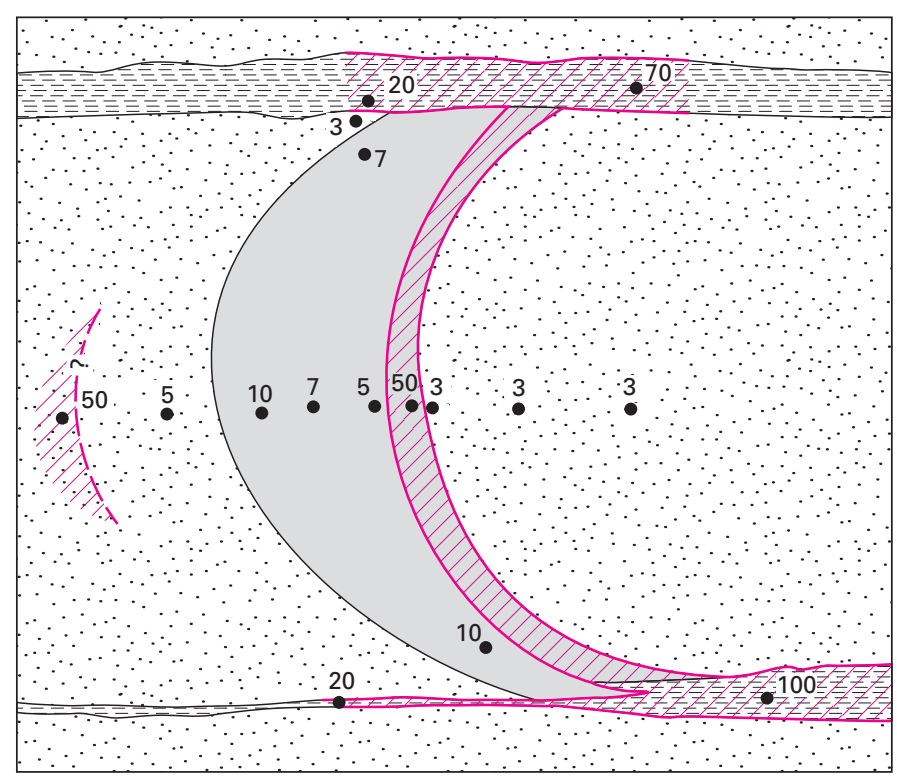

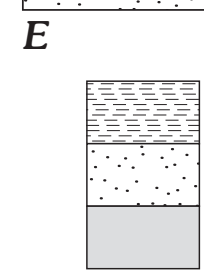

EXPLANATION

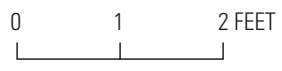

ELEMENT DISTRIBUTION

$\mathrm{Cr}$ in parts per million

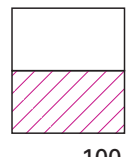

- 100 Sample point and value

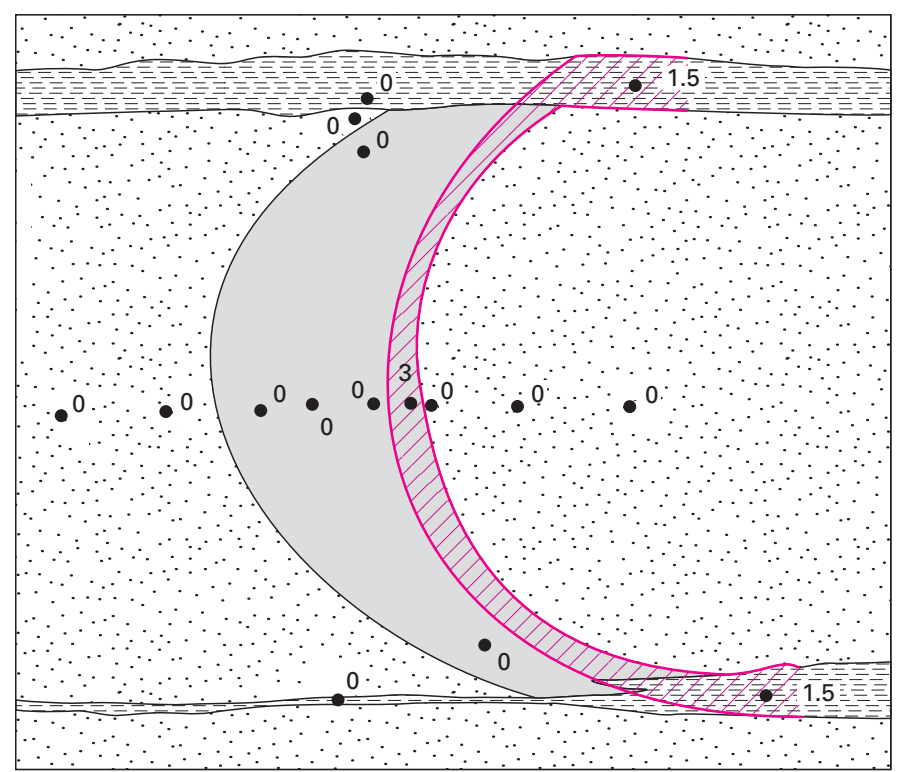

$F$

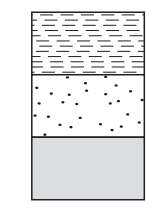

\section{EXPLANATION}

ELEMENT DISTRIBUTION

Ag in parts per million

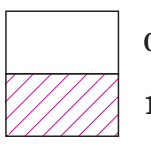

- 1.5 Sample point and

1.5 to 3

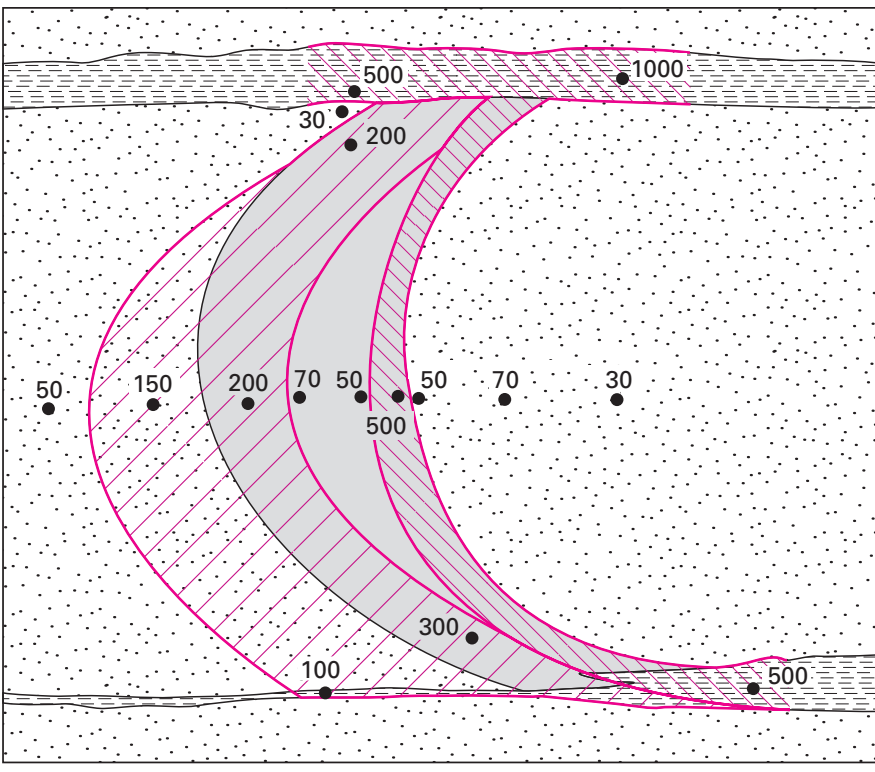

G

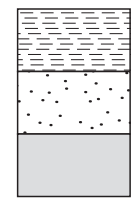

Mudstone

Barren sandstone

Mineralized sandstone

2 FEET

ELEMENT DISTRIBUTION

$\mathrm{Pb}$ in parts per million

30 to 70

500 to 1000

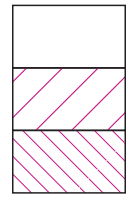

100 to 300

- 500 Sample point and value

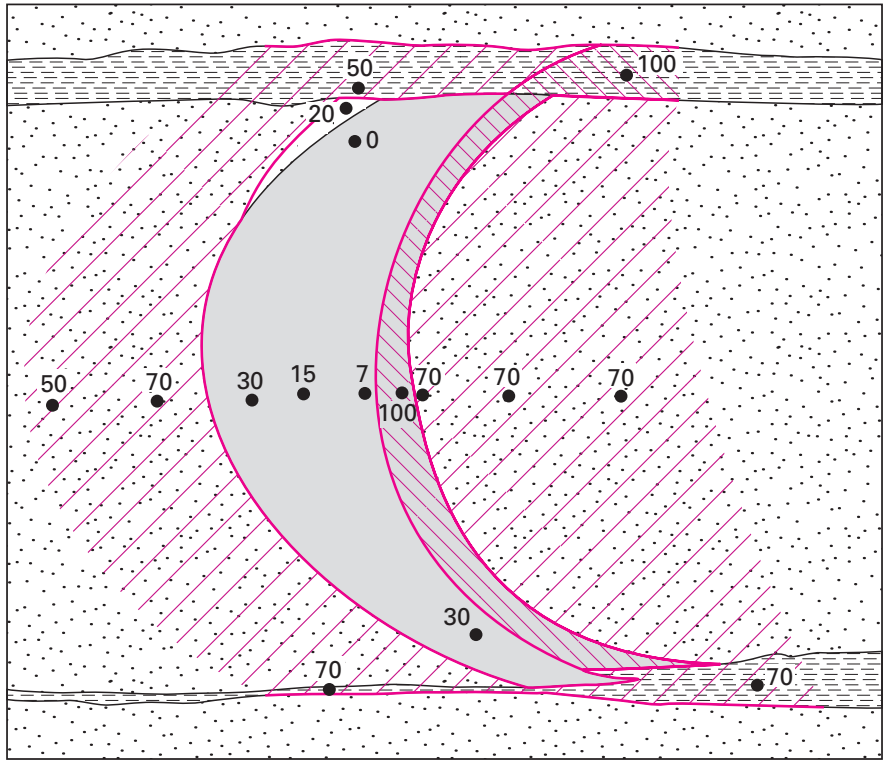

H

EXPLANATION

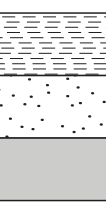

Mudstone

ELEMENT DISTRIBUTION

Mo in parts per million

value
Barren sandstone

Mineralized sandstone

2 FEET
0

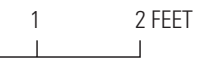

0 to 30

50 to 70

100

- 70 Sample point and value

$\begin{array}{lll}0 & 1 & 2 \text { FEET }\end{array}$ 


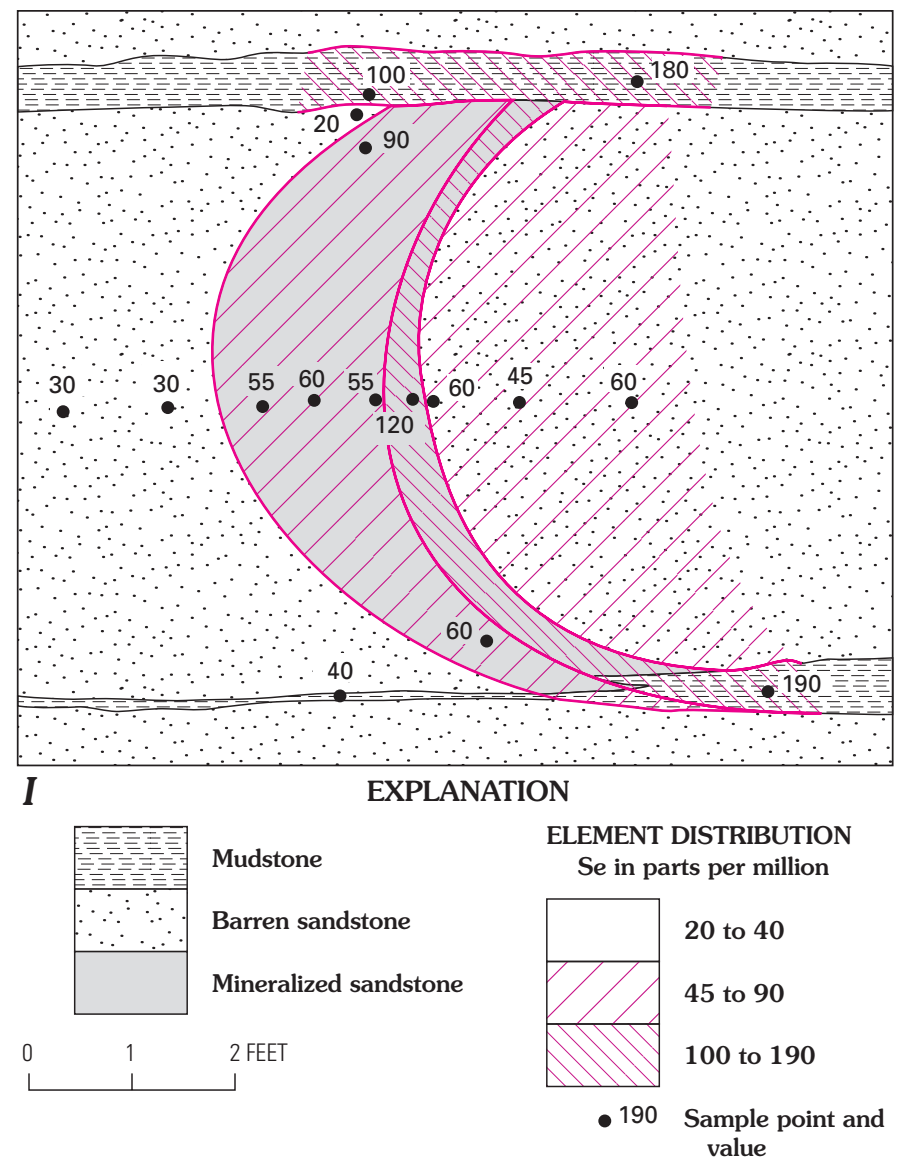

Differences in distribution in the rolls of some elements are noted where higher chromium occurs in barren sandstone beyond the convex surface of the roll (fig. $42 E$ ), and where lead (fig. 42G), molybdenum (fig. 42H), and selenium (fig. $42 I$ ) are in relatively low amounts in zones within the roll. Lead in minor amount occurs in barren sandstone near the convex surface of the roll (fig. 42G); and molybdenum, except in a high concentration zone at the concave surface of the roll, is very low in the roll, but shows higher concentrations in barren sandstone both on the concave and the convex sides of the roll (fig. $42 \mathrm{H}$ ). Moderate amounts of selenium occur within much of the roll, and also in barren sandstone on the concave side of the roll (fig. 42I). Significance of these variations is uncertain.

Copper (fig. 42J) appears restricted to the body of the roll and to adjacent mudstone layers. Copper within the Burro No. 7 ore roll is more or less evenly distributed. Perhaps because of lack of precision of the semiquantitative spectrographic analyses made for copper content of these samples, zonation of copper in the roll is not evident. However, the amount of copper is relatively low in the Burro No. 7 roll compared to other (oxidized) rolls in the district, possibly because the Burro No. 7 may lie beyond the zone of copper enrichment (fig. 38).

Amounts of sulfur (fig. $42 \mathrm{~K}$ ) and zinc (fig. $42 \mathrm{~L}$ ) are significantly more abundant in barren sandstone on the convex side of the roll ore body than within mineralized rock. Barium

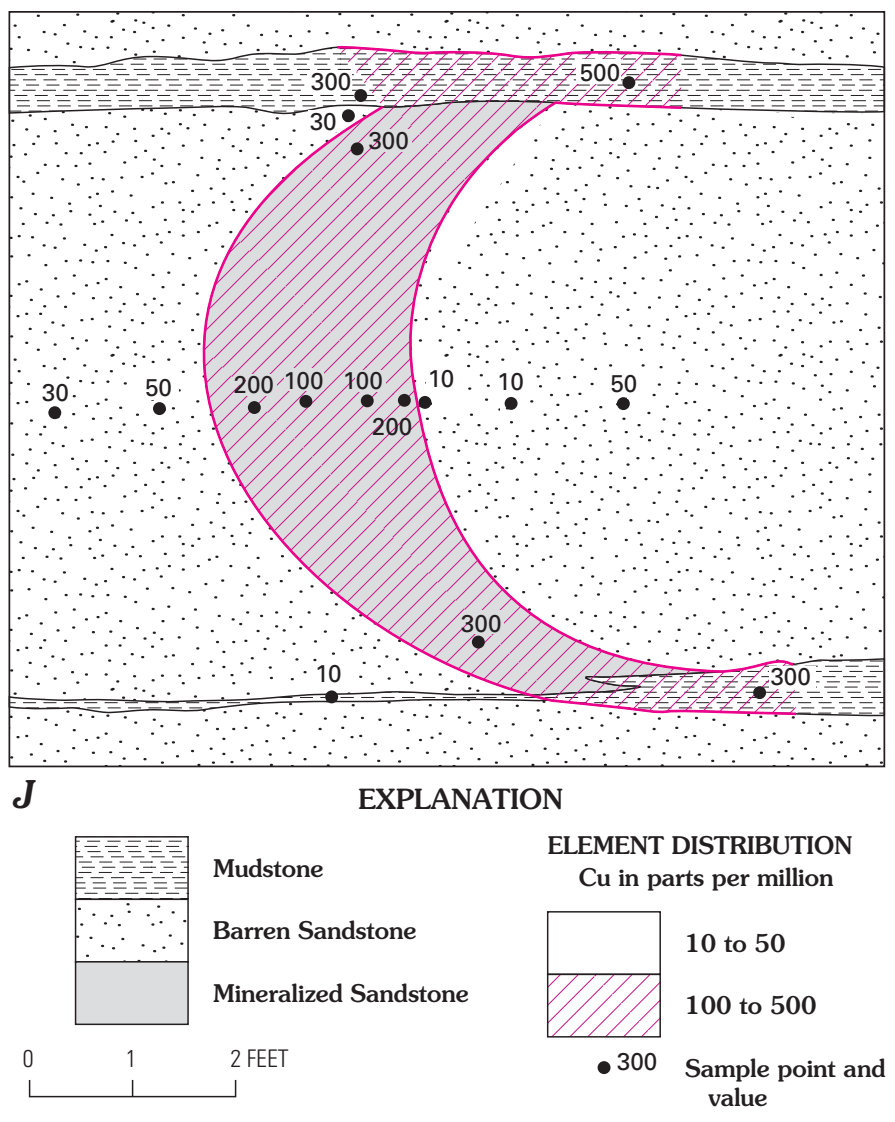

(fig. 42M) enrichment is greatest within the core of the roll, and is less abundant toward the convex side of the roll (compare heavy-mineral studies that showed greater abundance of barite within ore than in adjacent barren sandstone on either side of oxidized rolls; see figs. $31 A, B$, and $C$ ); barium is present in low amounts on either side of the roll as well as in a narrow zone inside the concave surface and in adjacent mudstone layers. Several elements (beryllium, gallium, lanthanum, and nickel, not illustrated) for which analytical data are available for the Burro No. 7 mine roll, are present mostly in amounts below-detection (not detected by semiquantitative spectrographic analysis used). Nevertheless, higher values reported for these elements occur in a zone near the concave surface of the roll, or in mudstone above and below the roll on the concave side of the roll, in accord with the tendency for beryllium, gallium, lanthanum, and nickel to accompany vanadium assimilation in clays (George Breit, USGS, written commun, 2008).

Sulfur shows a remarkably higher concentration in barren sandstone on the convex side compared to the concave side of the roll, suggesting possible derivation from trapped formation water. Accumulation of sulfur ions by biogenic decay of plant debris (along with development of humates that likely caused early accumulation of uranium) probably accounts for the higher concentration. According to studies by Breit and Goldhaber (1995), isotopic composition of sulfur in the Slick Rock ores indicates biogenic origin. Presence of sulfur in formation 


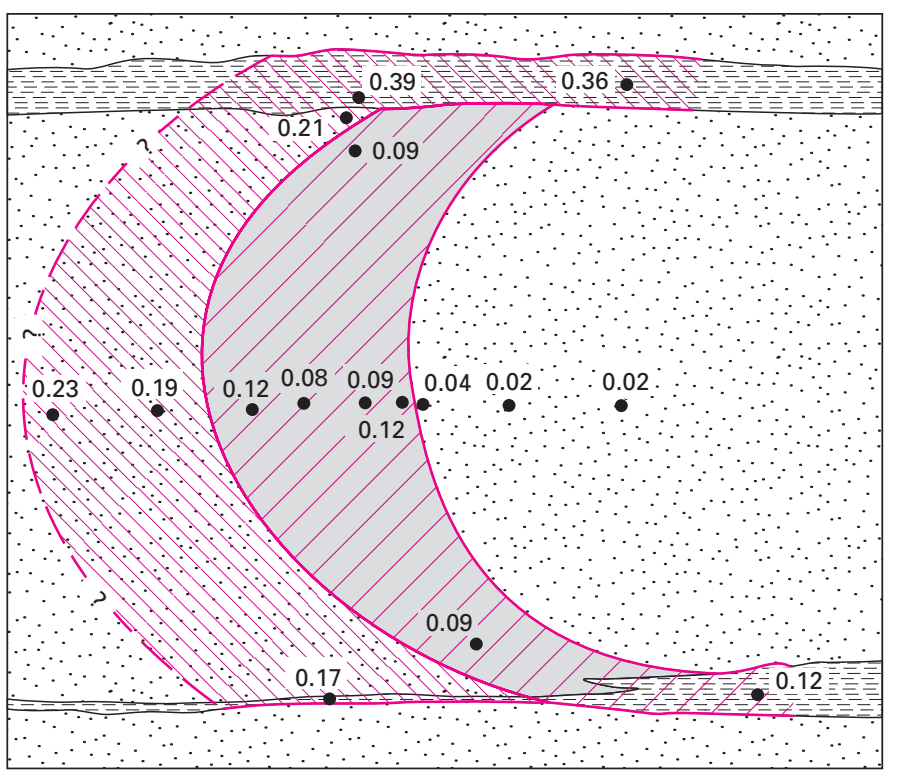

K

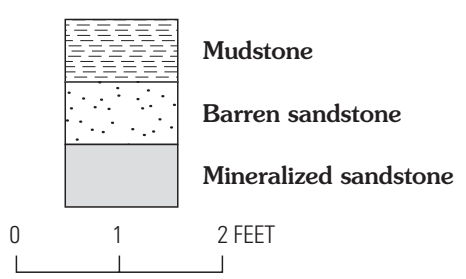

ELEMENT DISTRIBUTION

$\mathrm{S}$ in percent

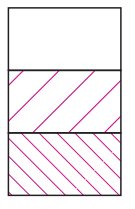

0.02 to 0.04

0.08 to 0.12

0.17 to 0.39

• 0.12 Sample point and value

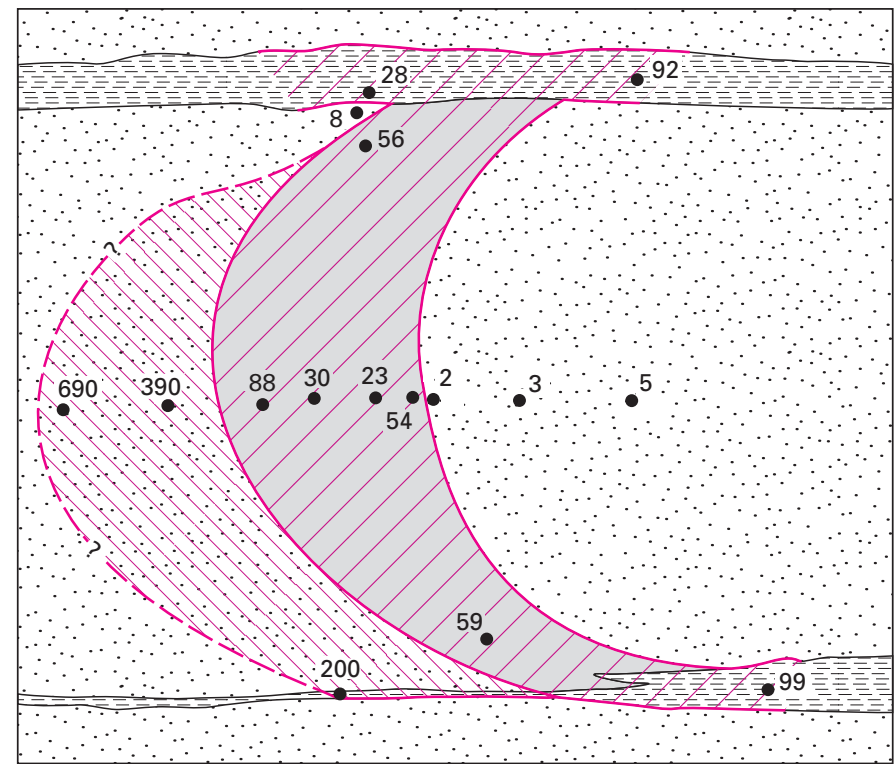

$L$

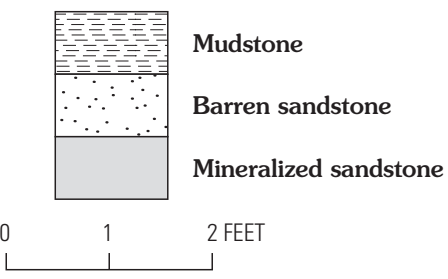

ELEMENT DISTRIBUTION

$\mathrm{Zn}$ in parts per million

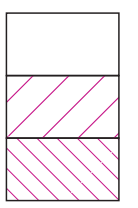

- 99 Sample point and value

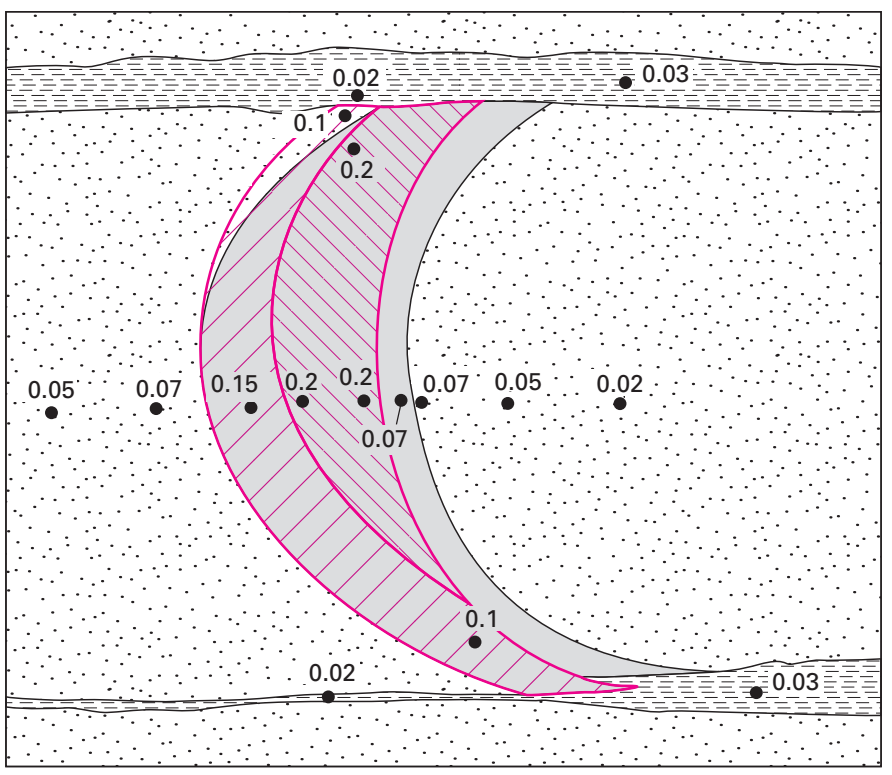

M

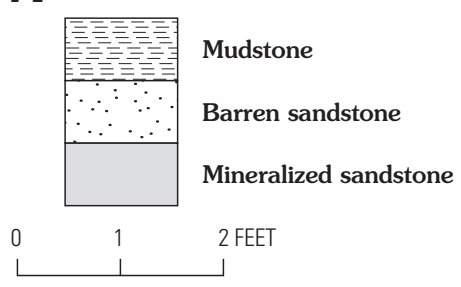

ELEMENT DISTRIBUTION Ba in percent

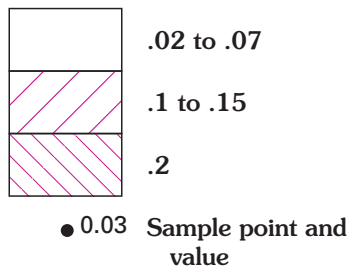

water would account for continual precipitation of lead sulfide along with radioactive decay of uranium, and ultimate precipitation of several sulfides and barite where introduced fluids came in contact with the formation water.

Vanadium, concentrated significantly near the interface position, but diminishing consistently toward the convex side of the roll, likely was transported to the position of precipitation in introduced fluid, and precipitated most abundantly where chemical gradient was greatest at the interface. As suggested earlier, abundance of vanadium in mudstone layers above and below the concave side of the roll may be attributable to ready addition of vanadium, derived from introduced fluid, to the structure of clays in the mudstone layers. Interstitial clay (detrital illite-smectite) filling pore space among detrital grains in sandstone was receptive of vanadium within the forming roll.

Similarity in distribution of elements iron, titanium, chromium, silver, and selenium (figs. $42 C, D, E, F$, and $I$ ) to that of vanadium suggests ready precipitation in clays of the iron, titanium, and chromium, along with vanadium, as well as similar derivation from introduced fluid.

Areal zonation of lead (common lead, as elaborated earlier, p. 47) and molybdenum relative to the zones of faults (Dolores and crossing zones, figs. 39, 41), relates them to introduced water, and distribution of these elements relative to the inferred interface in the Burro No. 7 ore roll (figs. $42 G, H$ ), is also consistent with the introduced fluid as their source. 
Beryllium, gallium, lanthanum, and nickel were detected only near the concave surface of the roll; source of these elements likely, though not certainly, was the introduced fluid. Data described earlier (p. 46) show that nickel in the ores is greatest near the zones of faults, hence probably introduced by altering fluids (fig. 41).

Distribution of elements in the unoxidized roll in the Burro No. 7 mine confirms the inference that two fluids of different chemical compositions interacted at a solution interface to cause deposition of the ore body.

\section{Lead-Isotope Data for the Burro No. 3 Roll Ore Body}

An unoxidized roll ore body in the Burro No. 3 mine, similar in form and setting to the roll in the nearby Burro No. 7 mine just discussed, was sampled by Alice Weeks, USGS, in 1957 to evaluate the lead-isotope compositions of lead minerals in the deposit. Three samples were collected (fig. 43), from which galena and clausthalite were separated and analyzed by Lorin Stieff and coworkers previously with USGS (Stieff, L.R., Stern, T.W., Cuttitta, Frank, Warr, J.J., and Delavaux, Maryse, 2009, Colorado Plateau lead-isotope age studies, USGS unpubl. manuscript) for $\mathrm{Pb}^{204}, \mathrm{~Pb}^{206}, \mathrm{~Pb}^{207}$ and $\mathrm{Pb}^{208}$ contents. Results shown in figure 44 are a comparison of ratios of the isotopes: $\mathrm{Pb}^{206} / \mathrm{Pb}^{204} \mathrm{vs} \mathrm{Pb}^{207} / \mathrm{Pb}^{204}$. Although precision of analyses of $\mathrm{Pb}^{204}$ made 50 years ago was not as good as it now is, the quite minor amount of $\mathrm{Pb}^{204}$ in lead minerals compared to the other lead isotopes suggests that potential minor variations in plots of the isotopes does not affect the general compositional variations shown in figure 44 (Lorin Stieff, written commun., 2008).

As shown in figure 44, sample 614 (galena and clausthalite) from barren sandstone near the inside surface of the roll and sample 615 (galena and clausthalite) from mineralized sandstone 1-3 in. just inside the surface of the roll are similar. Sample 616 (clausthalite) from mineralized sandstone collected from about one foot inside the ore roll is greatly enriched in uranogenic lead relative to those near the concave surface of the roll, suggesting two different sources of lead. The plots show that uranogenic $\mathrm{Pb}^{206}$ and $\mathrm{Pb}^{207}$ are much more abundant in the sample from well within the roll than in the other two samples. The abundant $\mathrm{Pb}^{206}$ and $\mathrm{Pb}^{207}$ suggests accumulation of radiogenic lead from a uranium-rich source on the convex (formation water) side of the roll, in contrast to a uranium-poor source on the concave (introduced water) side of the roll.

Other samples from Slick Rock are numbers 455 and 504 (Stieff and others, USGS unpub. manuscript, 2009), galena from barren sandstone (altered facies) in the Brushy Basin Member, and samples 68(1) and 68(2), galena and naumanite from nodules in barren sandstone (also altered facies) near ore in the Cougar mine. No information is available as to the specific collection sites of the nodules, but typically such samples come from the concave sides of rolls, as illustrated in figures
21 and 22. The four samples group closely with samples that have lead-isotope compositions typical of common lead (fig. 44).

\section{History of Lead in the Burro No. 3 Roll Ore Body}

According to Zartman (1974, p. 800) an area along the western margin of the North American continent (the same area as the western magmatic belt which was the source of Brushy Basin volcanic materials) was likely underlain by rocks only younger than Precambrian. Melting of these rocks in Late Jurassic time formed magma that contained most of the rocks' original uranium plus accumulated uranogenic lead. Materials of volcanic eruptions, both air-borne ash and stream-transported debris, were spread eastward and deposited with other materials in the Brushy Basin Member. Uranium contained in the volcanic ash continued to decay, forming more uranogenic lead that was added to that already present. When the ash devitrified as a result of weathering beginning not long after deposition (in an oxygenated environment conducive to formation of red-beds facies), uranium and uranogenic lead went into solution in Brushy Basin pore water. The high $\mathrm{pH}$ favored calcite precipitation in red-beds-facies rocks and although it may have precipitated some uranogenic lead, because of lack of sulfate most lead was not precipitated. Radiogenic lead was carried in groundwater with uranium when it moved into the underlying uppermost sandstone unit of the Salt Wash Member, where the uranium was taken up by humic acids. Lead was precipitated as sulfide upon contact with biogenic sulfur in the organic-rich stagnant water of the Salt Wash.

\section{Uranium-, Thorium-, and Protactinium-Isotope Data for the Burro No. 7 Roll Ore Body}

Rosholt and others (1965a) determined that there was very little difference in $\mathrm{U}^{234}$ content among the samples in and near the roll ore body in the Burro No. 7 mine (see section on individual element distributions in these samples described earlier, p. 47-56). The roll ore varied between only 5 percent deficient to 2 percent excess of $\mathrm{U}^{234}$, indicating a relative lack of leaching of the $\mathrm{U}^{234}$ isotope, which Rosholt and others (1965a) attributed to the high reducing potential of the environment. This evidence may indicate that little leaching took place that moved any of the elements in the unoxidized ore since its deposition.

\section{Strontium-Isotope Distribution Related to Position of Ore Deposits}

Breit and others (1990) described decreases in strontium contents and in $\mathrm{Sr}^{87} / \mathrm{Sr}^{86}$ ratios in barite with distance from the Dolores fault zone, central to the distribution of ore deposits in the district, as indicative of outward movement from the faults 


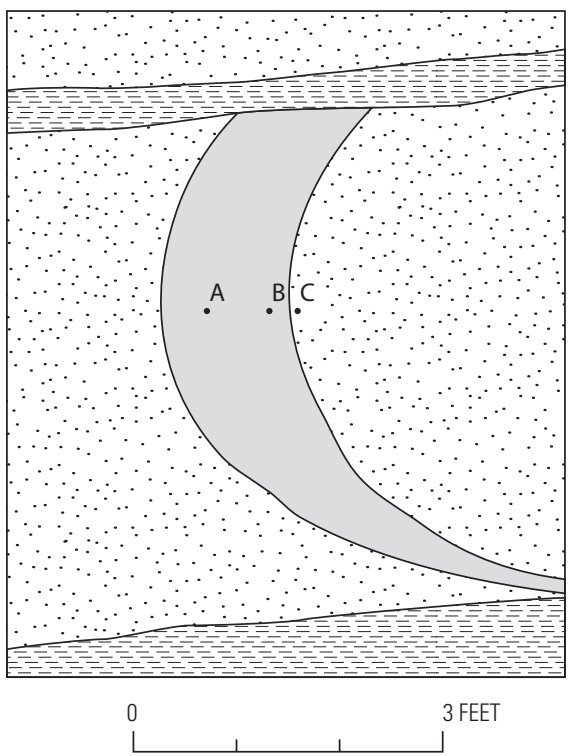

EXPLANATION

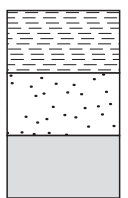

Mudstone

Barren sandstone

Mineralized sandstone

ORE SAMPLES
Figure 43. Diagram of an unoxidized ore roll in the Burro No. 3 mine sampled by Alice Weeks, then of USGS, showing locations of samples for which lead-isotope compositions of lead minerals were determined (by L.R. Steiff and others, USGS unpub. report, 2009).

\begin{tabular}{|c|ccc|cc|}
\hline $\begin{array}{c}\text { Lead-isotope } \\
\text { ratio }\end{array}$ & A (616) & B (615) & C (614) & $\begin{array}{c}\text { Cougar } \\
\text { mine }\end{array}$ & $\begin{array}{c}\text { Cashin } \\
\text { mine }\end{array}$ \\
\hline $204 / 207$ & 0.055 & 0.063 & 0.064 & 0.065 & 0.063 \\
$204 / 208$ & 0.026 & 0.026 & 0.026 & 0.026 & 0.026 \\
$206 / 207$ & 3.66 & 1.38 & 1.36 & 1.23 & 1.30 \\
$207 / 206$ & 0.27 & 0.73 & 0.73 & 0.81 & 0.77 \\
\hline
\end{tabular}

of transporting water derived from the underlying Hermosa Group. The $\mathrm{Sr}^{87} / \mathrm{Sr}^{86}$ ratios corroborate control by the fracture system of introduced fluid as indicated by distribution of altered-facies sandstone and by district-wide distribution of the elements copper, lead, molybdenum, and nickel.

\section{Chemical Character of Formation Fluids Involved in Genesis of the Ores}

The following discussion considers the origin of different fluids inferred either to have acquired uranium, to have transported the uranium and introduced it to the present site of the ore deposits, or to have caused its precipitation at the site. The mineral and organic carbon compositions of various sedimentary units considered to have been important at stages in ore genesis (red-beds-, carbon-, and altered-facies sandstone, as well as some source rocks) suggest chemical character of the contained fluids specific to each facies. Part of the following discussion is based on mineralogic studies of Slick Rock sedimentary rocks by George Breit (1986; and oral and written communs., 2008).

Red-beds-facies sandstone in the Salt Wash Member of the Morrison Formation contains diagenetic calcite, chalcedony, illite-smectite, and hematite or goethite. The facies also contains original detrital iron-titanium-oxide minerals. Fluid in which these minerals formed or were retained was oxidizing with respect to iron oxides, and during deposition water saturation of the sediment varied cyclically with the seasons. 


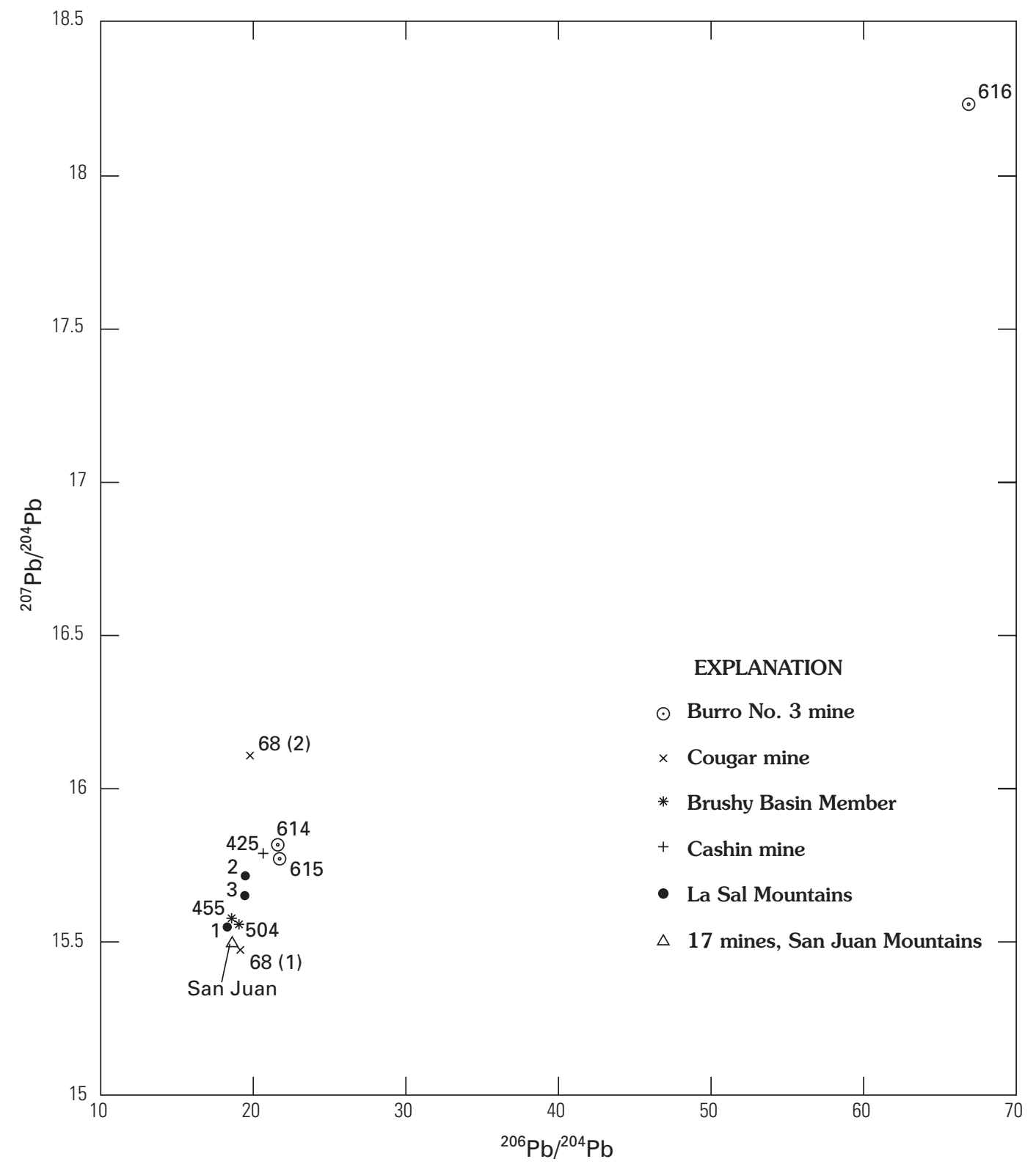

Figure 44. Plot of ratios of lead-isotope compositions $\mathrm{Pb}^{206} / \mathrm{Pb}^{204}$ vs $\mathrm{Pb}^{207} / \mathrm{Pb}^{204}$ of lead mineral samples from different localities, determined circa 1960 by Stieff and others, 2009 (unpub. USGS report). Locations of samples $(614,615,616)$ of galena and clausthalite in and near a roll in the Burro No. 3 mine at Slick Rock are shown in figure 43. Samples (68(1), 68(2)) from the Cougar mine at Slick Rock are of galena and naumanite nodules in sandstone. Samples $(455,504)$ from the Brushy Basin Member of the Morrison Formation at Slick Rock are of galena from drill core. The sample (425) from the Cashin mine is of galena disseminated in sandstone in the Salt Wash Member of the Morrison. The samples from the La Sal Mountains are of potassium feldspar from laccolithic intrusions. Average composition is shown of samples of galena from 17 base- and precious-metal mines in the San Juan Mountains. Details of certain specific characters of samples are given in the text. 
Rocks in the Brushy Basin Member overlying the Salt Wash also are of the red-beds facies. With shallow burial, these sediments contained fluid whose composition caused devitrification of abundant volcanic ash in the Brushy Basin.

Sandstone of carbon facies in the Salt Wash Member contains diagenetic calcite, illite-smectite, pyrite, and chalcedony, and locally abundant carbonized plant fragments, developed from the time of deposition in the Late Jurassic. Fluid in which these minerals formed filled fluvial sandstone strata below a generally constant water table. Proximal to carbonaceous matter, ferric iron and sulfate were chemically reduced. Humic acids which formed from decaying organic material survived burial, although heat from deep burial terminated their formation. Association of humates with fossil plant materials has been evaluated by Swanson and Palacas, 1965; Hansley and Spirakis, 1992; and Spirakis, 1996. Sulfate was reduced to sulfide (biogenic S) due to the presence of decaying plant materials (Jensen, 1958). Generation of biogenic sulfide was terminated with deep burial. This water was strongly reducing, sufficient to cause partial dissolution of iron-titanium-oxide detrital minerals.

Altered-facies sandstone in the Salt Wash Member, including uranium-vanadium mineralized sandstone, in which detrital black-opaque iron-titanium minerals largely were dissolved by solutions introduced in the Late Cretaceousearly Tertiary as earlier indicated, retained original diagenetic illite-smectite and calcite, and it contains authigenic barite and anatase recrystallized from diagenetic forms. Hydrocarbons might have been involved in formation of altered-facies sandstone and the contained uranium-vanadium deposits, based on the expected chemistry and movement of petroleum and its gases in sedimentary strata (George Breit, oral commun., 2008). I have not considered this possibility sufficiently to incorporate it into my understanding of the various stages of ore formation, or to suggest modification of my inferences because no evidence exists of residual petroleum in the Slick Rock strata, as it does in the host rocks of the Cashin mine (MacIntyre, 2004) where petroleum has been inferred as an agent in genesis of that ore.

In addition to strata of the three facies in the Morrison Formation, a fourth stratal unit was important in generating fluids responsible for formation of the Slick Rock uraniumvanadium ore deposits. The evaporitic-sapropelic Paradox Formation of the Middle and Upper Pennsylvanian Hermosa Group contained a large amount of organic-rich sediment as well as sodium chloride $(\mathrm{NaCl})$, so that contained formation water was strongly reducing (high methane $-\mathrm{CH}_{4}$ - content) and saline (high chloride content). The fluid was capable of transporting several metal ions derived from enclosing sedimentary rocks and probably also from magmatic fluids from the La Sal laccolith magmas, when mobilized and introduced into the Morrison Formation in early Tertiary time.

In the Brushy Basin red-bed sediments above Salt Wash Member sandstone, which Waters and Granger (1953) inferred to be the source of the uranium in the Salt Wash Member ore deposits, the uranium (released from devitrified volcanic glass) was present in formation water as the uranyl ion $\left(\mathrm{UO}_{2}{ }^{2+}\right)$ that formed strong complexes with carbonate in the alkaline fluids (Langmuir, 1978). The uranium in solution in Brushy Basin formation waters moved from compacting clay-rich rocks, in part by weight of overlying sediments, into relatively porous (lower fluid pressure) sandstone strata of the Salt Wash Member, in the period probably from shortly following deposition and well into the Cretaceous. Uranium was bound to humate molecules upon passage into carbonaceous Salt Wash formation water. When Salt Wash formation water was later (in the early Tertiary) exposed to introduced fluid, precipitation of elements from both fluids took place at an interface (for example, the position of a roll ore body), mostly by diffusion of uranium from pore water and diffusion of some other elements that were constantly re-supplied by continually flowing introduced water.

Epigenetic minerals formed by interaction of the two fluids included calcite, quartz, barite, anatase, and pyrite, as well as uranium-vanadium minerals, other sulfides, and selenides. Detrital illite-smectite was in part converted to vanadian illitesmectite and in part replaced by vanadian chlorite. Because of its contained methane $\left(\mathrm{CH}_{4}\right)$ and saline character (chloride ions), introduced water likely carried significant barium and strontium in solution which was precipitated in barite, but also it carried copper, lead, molybdenum, nickel, and selenium derived from La Sal Mountains laccolithic magmas, as discussed earlier in this report (p. 46-47). During movement of the reducing solution on its course through porous sandstone to the site of ore deposition, detrital iron-titanium-oxide minerals in the conducting strata were dissolved (a characteristic of altered facies), from which the solution acquired vanadium, chromium, iron, and titanium. Leucoxene remnants of partially dissolved detrital iron-titanium-oxide minerals recrystallized as anatase, or possibly were partially replaced by rutile. As introduced water moved through porous sandstone strata of the Salt Wash Member, minor amounts of common lead and uranium were deposited as described earlier, apparently the cause of the higher content of these elements in altered rock over that in red-beds strata (Shawe, 1976a).

Implicit in the model of ore deposition described here is the perception that the volume of trapped formation water relative to the volume of introduced water flowing continuously along a roll surface was very small, probably orders of magnitude less. If any ore components were derived from the trapped formation water and precipitated at the solution interface in substantial quantities, their original concentrations in the necessarily small volume of formation water trapped in the host rock must have been quite high, perhaps implying a long period of accumulation prior to precipitation. Considering the probability of large-volume flow of introduced solution along established pathways over a long period of time, it is evident that large amounts of some ore components could have been brought to the solution interface in very low concentrations.

According to Breit and Munier (1990), an oxidizing fluid would be required to carry significant copper to sites of deposition in the Lisbon fault system, and also to deposits such as 
the Cashin mine and uranium-vanadium deposits in the Uravan mineral belt. They (Breit and Munier, 1990) concluded that copper in the Slick Rock ores must have been introduced in a separate (oxidizing) fluid that followed the same pathway as the earlier reducing fluid which initially deposited the uranium-vanadium ore bodies. I believe there is no evidence of such a fluid having passed through altered-facies sandstone. But if cuprous copper formed complexes such as $\left[\mathrm{Cu}\left(\mathrm{NH}_{3}\right)_{2}\right]+$ or $\left[\mathrm{Cu}(\mathrm{CN})_{2}\right]-($ Sneed and Maynard, 1944, p. 628-629), it would be capable of transport in reducing fluid. Even if carried in only low concentration, the likelihood of large volume flows of introduced solution needed to form the Slick Rock uranium-vanadium deposits could well supply the relatively small amount of copper in the ores.

Uranium was not deposited in mineral form upon movement from the Brushy Basin into the Salt Wash, but instead remained suspended in trapped formation water adsorbed by humate gels developed near carbonized plant materials. The gels localized around larger organic materials, but some were precipitated as minute fragments or films of organic materials that were spread sporadically along bedding layers. Uranogenic lead formed near the accumulations over an uncertain period of time (perhaps about 125 million years) in the Late Jurassic to early Tertiary. Upon formation, uranogenic lead, bound in the uranium phase, combined with biogenic sulfur ions associated with organic matter which had begun forming in the early diagenetic development of carbon facies. Any age determination based on lead-isotope ratios of continually accumulating lead sulfide would indicate an "average" date for the period of uranium and lead accumulation (an open system) in the Salt Wash, not the time of later ore-mineral deposition as a result of introduction of an extraneous solution.

Erosion eventually reached some of the uranium-vanadium deposits, causing near-surface weathering and oxidation where potassium feldspar and quartz were stable, and sodium feldspar, chlorite, and carbonates were dissolved.

\section{Regional Relations of Ore Deposits}

The ore deposits at Slick Rock are related to a particular widespread geologic (tectonic and magmatic) episode, which occurred in the early Tertiary throughout the Colorado Plateau and in some adjacent areas. This conclusion is indicated by lead-isotope, chemical, and age data, together with geologic data presented earlier in this report and in other publications.

\section{Lead Isotopes}

Unpublished studies of lead isotopes in uranium-vanadium deposits in the Slick Rock district (including the data discussed earlier), in other Colorado Plateau localities, and in localities near the plateau by Stieff and others (USGS unpub. report, 2009) are used in this evaluation. As discussed in following pages "common lead" is considered to have been derived from minerals in Precambrian basement rocks that contained typical crustal amounts of uranium and thorium. At the time of formation of the uranium-vanadium deposits (late Oligocene) as a result of magma generation in the basement, isotopic composition of the magma and basement likely were similar.

Lead-isotope compositions of most lead minerals from Slick Rock, from the Cashin mine, and from some base-metal mines in the San Juan Mountains (see fig. 44), show a commonality indicative of lead derivation from average crustal rocks containing minerals with only minor uranium and thorium. The similarity suggests that the deposits likely were all formed during one widespread geologic episode, perhaps lasting for a prolonged time but varying in duration locally.

\section{Chemical Correlations}

Copper, lead, molybdenum, and nickel in Slick Rock uranium-vanadium deposits are most highly concentrated near the intersection of the Dolores fault zone and crossing zone of faults (figs. 38-41). Fluid that moved up and along the faults and altered strata through which it passed (Shawe and others, 1959, figs. 2, 9), contained metals initially present as well as those acquired from altered strata. As the fluid moved outward through permeable units it deposited copper, lead, molybdenum, and nickel. Similarly, the fault-localized Cashin copper-silver deposit, near the southwest margin of the nearby Paradox salt anticline, exhibits zoned copper, lead, arsenic, and zinc extending outward from the fault (MacIntyre, 2004, p. 186). The Cashin deposit contains anomalous elements present in some Slick Rock ores, including copper, silver, arsenic, lead, zinc, cadmium, molybdenum, and nickel, and are all considered to have been added (MacIntyre, 2004, p. 187). The similarity of the occurrences suggest that copper and these other metals in the Slick Rock deposits likely were introduced by similar fluid along the zones of faults, in a manner similar to the probably penecontemporaneous introduction along a fault into the Cashin deposit (MacIntyre, 2004). Introduction of copper into the Lisbon zone of faults (Breit and Meunier, 1990) most likely took place at the same time.

Coleman and Delevaux (1957) recognized high amounts of selenium in chalcopyrite from diorite porphyry from the nearby La Sal Mountains. They also stated (1957, p. 525-526) that the high content of selenium in base-metal hydrothermal ores from the Colorado Plateau may indicate a source in igneous intrusions enriched in selenium, or perhaps from seleniferous sedimentary beds. According to Coleman and Delevaux (1957), "The ultimate source of the selenium in the sulfides of the Colorado Plateau...can be related to a magmatic province that has contained exceptionally high selenium during periods of volcanic and intrusive activity in Mesozoic and Tertiary times."

If the mineralizing solution responsible for the Slick Rock deposits was derived in part from, or mobilized by, magmas of the La Sal laccoliths, impetus for movement was decreased density of the heated fluid, and thus tendency to 
flow upward rather than laterally. Fluid likely did not move laterally from the present position of the laccoliths, but rather, it entered the fracture systems at depth, to move up faults into the zone where the ores were deposited.

\section{Age Correlations}

Ages of the Colorado Plateau uranium deposits have been the subject of speculation beginning with studies in the late 19th century. More recently, radiometric analyses of uranium minerals and associated lead minerals have provided firmer age data. Stieff and others (1953) concluded that the Colorado Plateau uranium deposits were of Late Cretaceousearly Tertiary age. Ludwig and others (1984) determined an age of about $132 \mathrm{Ma}$ for ores in the Grants, N. Mex. district. The early Tertiary (Eocene-Oligocene) was the likely time of uranium ore deposition, based on uranium-lead data (Lorin Stieff, written and oral communs., 2003-2008). Uncertainties remain, related to locations of deposits, assumed process of origin, and assumptions used in calculation of ages.

Geologic evidence indicates that the existing forms of the Slick Rock uranium deposits are no older than Late Cretaceous or Tertiary. Faults breaking Upper Cretaceous rocks (Dakota Sandstone and Mancos Shale) controlled introduction of extraneous mineralizing fluids. Epigenetic alteration of the Salt Wash sandstones resulted from introduction of an extraneous solution along zones of faults coincident with the distribution of the uranium deposits (Shawe, 1976a).

Shawe and others (1959) speculated that intrusion of the La Sal Mountains laccoliths may have been related to mineralization of the Slick Rock deposits. Stern and others (1965) suggested that because the lead isotope compositions of feldspars from the La Sal igneous rocks are similar to lead isotope compositions of some galenas from Colorado Plateau uranium ores, the leads may share a common progenitor. An early attempt to date intrusion of the La Sal Mountains rocks (Stern and others, 1965) by zircon uranium-lead and thoriumlead analyses indicated an age of $32 \pm 2 \mathrm{Ma}$ (based on $\mathrm{Pb}^{206}$ / $\mathrm{U}^{238}$ ) and $28 \pm 2 \mathrm{Ma}$ (based on $\mathrm{Pb}^{208} / \mathrm{Th}^{232}$ ) for soda syenite porphyry, and $32 \pm 2 \mathrm{Ma}$ (based on $\mathrm{Pb}^{206} / \mathrm{U}^{238}$ ) and $40 \pm 6$ $\mathrm{Ma}$ (based on $\mathrm{Pb}^{208} / \mathrm{Th}^{232}$ ) for monzonite porphyry. Much older dates obtained for diorite porphyry were attributed by Stern and others (1965) to the effect of inherited Precambrian zircons. Potassium-argon dates (Stern and others, 1965) for aegerine-augite from soda syenite porphyry of $25.5 \pm 2.5 \mathrm{Ma}$ and aegerine-augite from monzonite porphyry of $22.5 \pm 3.3$ Ma suggest that similarities amongst the determined dates indicate likely time of emplacement in latest Oligocene-earliest Miocene time. More recently, Nelson and others (1992), using the ${ }^{40} \mathrm{Ar} /{ }^{39} \mathrm{Ar}$ dating method on potassium feldspars from the intrusive rocks of the La Sal Mountains, determined ages of 28-25 Ma (latest Oligocene) that provide specific corroboration of the earlier determined ages.

Mineral fluid inclusions in the overlying Mancos Shale (Shawe, 1976a), which are probably indicative of a maximum temperature attained when most deeply buried in the early Tertiary, about $110^{\circ} \mathrm{C}$, may indicate the approximate temperature of deposition of the Slick Rock ores. On the other hand, such temperature could have existed at shallower depths if hydrothermal activity had raised rock temperature.

Date of intrusion of laccoliths in the La Sal Mountains, dates of igneous and mineralizing activity in the San Juan Mountains (late Oligocene and Miocene, Bove and others, 2001), and inferred age of the Slick Rock ore deposits are broadly coincident, reflecting an extensive regional geologic episode.

\section{Genesis of the Uranium-Vanadium Deposits}

The observations made and the data collected during our study of the Slick Rock uranium-vanadium ores allow several firm conclusions: 1) The ore bodies were deposited at an interface between two fluids of different chemical composition and redox potential; 2) One fluid was stagnant formation water and one fluid was introduced fluid which caused epigenetic alteration of the rocks through which it passed; 3) The ore bodies were deposited where pockets of strongly reducing formation water had developed around accumulations of carbonaceous plant material; 4) Lead isotope data indicate two distinct compositions (and hence sources) of uranogenic lead in the ore bodies, one typical of common (crustal) lead and one enriched in uranium; 5) Altered rocks, which formed as a result of the passage of an introduced fluid, are distinguished by the presence of lead minerals whose isotopic composition is typical of common lead; 6) The other fluid (formation water) carried lead greatly enriched in uranogenic lead and hence derived from a uranium-rich source; and 7) Formation water was enriched in uranium before it was encountered by introduced, altering fluid.

In the context of the above parameters, a rational concept of the origin and formation of the Slick Rock uranium-vanadium deposits can be inferred. Recognition of these critical elements of genesis did not occur simultaneously, but instead were recognized sporadically throughout our studies. Supplemented with much additional information, the elements now form the foundation of my current concept of genesis.

\section{Evolution of the Genesis Concepts}

Alteration events involved in genesis of the Slick Rock ores as described in an earlier report (Shawe, 1976a) included an early episode of diagenesis of the sedimentary rocks, forming both red-beds-facies and carbon-facies sandstone, processes not directly related to ore formation. I suggested acquisition to the ores of most ore components by way of a later introduced (and altering) solution (that formed altered-facies sandstone). The inference was based in part on the higher 
content of uranium in altered-facies (not mineralized) sandstone compared to red-beds-facies sandstone, and to elevated amounts of uranium in iron-rich deposits formed locally at contacts between altered-facies and red-beds-facies sandstone. The ore bodies were precipitated when introduced water carrying the ore elements came in contact with organic-rich formation (carbon facies) water, mostly concentrated in the upper sandstone unit of the Salt Wash Member. I described (Shawe, 1976a) a late episode of oxidation of the rocks resulting from uplift and recent weathering.

Studies (Breit and others, 1990; Breit and Goldhaber, 1995) that evaluated isotopes (of sulfur and strontium in barite), provided a better understanding of the timing and nature of the altering prosesses. These later studies indicated four major episodes of alteration: 1) Initial diagenesis which took place near the surface shortly following deposition of the sediments in the Late Jurassic (my episode of red-bedsfacies sandstone and carbon-facies sandstone development); 2) An episode that witnessed accumulation of some of the ore components (most importantly, uranium) that occurred following early diagenesis probably in the Early Cretaceous and prior to the time of precipitation of the ores as they now are configured (an episode which I had not considered); 3) An alteration event that accompanied precipitation of the ores in the early Tertiary (the event I postulated as precipitating the ores); and 4) Surficial weathering resulting from nearsurface oxidation of deposits following uplift and erosion in the late Tertiary-Quaternary, that allowed ingress of meteoric waters (an altering event that I also had suggested). Although more specific than my earlier evaluations of alteration, the more recent studies defined events similar to those earlier described. Evidence provided in this report now suggests (as did Breit and Goldhaber, 1995) that uranium (perhaps other ore components) accumulated early in the history of the sedimentary rocks and was precipitated in its present form only upon introduction of an extraneous (altering) fluid.

In earlier studies (Shawe and others, 1959; Shawe, 1976a), I postulated that the uranium-vanadium ores were deposited during the early Tertiary, at a time when the sediments were deeply buried (perhaps about 10,000 ft). I also suggested that the Upper Cretaceous Mancos Shale was a feasible source of water to have been introduced into the Salt Wash Member of the Morrison Formation to cause alteration and mineralization. With further study, I have concluded that chemically similar water from the underlying Hermosa Group was the more likely agent (Breit and others, 1990), as previously described.

\section{Extending the Concepts}

A long period of sporadic tectonism in the Western United States, from Cambrian to early Tertiary time, influenced provenance and deposition of sedimentary rocks which hosted the uranium-vanadium deposits in the Slick Rock district (Shawe, 1976b). This prolonged series of geologic events formed the character of the various rock units which ultimately controlled the genesis of the deposits. It influenced hydrologic regimes of various stratal units, and moved stratal fluids mobilized by igneous activity and controlled by rock permeability and fractures, by which components were moved from sources, through various stages, to ultimate deposition.

Deposition of a series of Paleozoic marine sedimentary strata on the western continental shelf of North America, including much of what is the present Western United States, followed development of a relatively flat erosional surface on Precambrian rocks (Shawe, 1976b). Organic-rich sapropelic strata and interlayered evaporite beds of the Paradox Formation of the Pennsylvanian Hermosa Group, deposited in a shallow basin (Paradox Basin) on the shelf, according to Breit and others (1990) constituted a stratigraphic facies favorable for development of a reducing fluid capable of altering red-bedsfacies strata, and with composition capable of transporting many of the components that ultimately were precipitated in the Slick Rock ores.

During the Jurassic and Early Cretaceous a magmatic (volcanic and intrusive) belt developed along the western margin of the continent, forming a broad basin which extended far to the east. Late Jurassic deposition in the basin of mostly terrestrial beds of the Salt Wash and Brushy Basin Members of the Morrison Formation set the stage for ultimate localization of sites of deposition of the uranium-vanadium ores. A local basin, overlying the earlier Paradox Basin, formed on the alluvial plain of the Salt Wash causing an alluvial-fan modification of deposition which shaped the position of the Uravan mineral belt (Shawe, 1962), the south part of which became the Slick Rock district. The Salt Wash sandstones were characterized locally by abundant plant remains which formed a chemically reducing environment (Shawe, 1976a). This environment favored accumulation of uranium introduced from overlying uranium-bearing volcanic materials of the Brushy Basin derived from the western magmatic belt.

In the environment of abundant organic material in the uppermost sandstone, introduced uranium became complexed by humic acids during early stages of burial. Throughout the Cretaceous Period and into the early part of the Tertiary (perhaps a hundred million years), uranium-bearing sandstone was buried to a depth of several thousand feet where humates were not formed owing to increased heat. During this period the pockets of stagnant organic-rich fluid in the Salt Wash became greatly enriched in uranium. I believe that continually forming uranogenic lead was precipitated as galena by associated biogenic sulfide ions. However, generation of uranogenic lead in formation water continued, increasing the amount of uranogenic lead sulfide present. Much of the radiogenic lead in formation water in the Salt Wash had been accumulating in successive environments for a long period of time.

A period of extensive tectonic and magmatic activity, dominantly volcanic around the periphery of the Colorado Plateau and intrusive within the plateau, began in the early Tertiary, and culminated in late Oligocene time. Emplacement of La Sal Mountains laccoliths just northwest of the Slick 
Rock district in latest Oligocene time likely induced movement of saline, reducing fluid from the underlying Hermosa Group through fractures into the Salt Wash Member.

Altering fluid driven by heat from the laccolithic intrusions and carrying vanadium and other elements from the magmas or picked up in transit, came in contact with trapped uranium-charged water around accumulations of organic material in the Salt Wash Member. Reduction of components in red-beds-facies sandstone (for example, conversion of irontitanium-oxide minerals to pyrite), as a result of reaction with introduced reducing fluid, would decrease the fluid's reducing potential. Introduced fluid adjacent to forming ore bodies thus was probably less reducing than humate-charged formation water with which it came in contact. Precipitation of the uranium-vanadium ores took place by interaction of the two fluids at an interface.

Evidence of dominant amorphous uranium oxides (as $\mathrm{UO}_{3}$ - see earlier discussion of mineralogy of the deposits, $\mathrm{p}$. 37-39) in much of the ore suggests that uranium may not have precipitated in crystal form because it was still adsorbed on humate gel. Unusually high amounts of uranium in unmineralized sandstone on the convex side of the ore roll, reflecting its inferred earlier concentration in formation water, may have resulted from precipitation of humate gel that did not migrate close to the interface. Addition of some elements (especially copper) in a separate, later mineralizing event which deposited minerals in close accord with the forms of earlier ore bodies seems unlikely. Changed hydrologic conditions, related to a difference in cause of solution flow, such as source of heat or other activating means, and different structural conditions (frequency and nature of conducting fractures) would likely exist if there had been a significant time gap between initial deposition and addition of other elements. Such a change in geologic conditions likely would have caused differences in the forms and element distributions in the earlier and later depositional bodies. Late Tertiary-Quaternary uplift and erosion exposed some of the ore deposits to weathering and oxidation.

\section{Acknowledgments}

From the start of geologic investigations by USGS in the Slick Rock district in 1947, and lasting into 1958, 12 separate drilling programs and more than 35 man-years of field and office work were completed. Many of the results of the drilling programs and geologic studies have been incorporated in this report. Between November 1947 and August 1953, USGS completed nine exploratory and development diamond-drilling programs in the district. These were directed by A.L. Bush, R.D. Trace, Henry Bell, III, C.F. Withington, L.S. Hilpert, W.L. Emerick, and J.L. Gualtieri. These geologists were assisted by geologists D.O. Beehler, Leonid Bryner, J.J. Folger (geologic field assistant), R.B. Hall, H.M. Icke, H.L. Jicha, H.S. Johnson, J.A. MacKallor, R.L. McDonald, C.H. Meissner, F.B. Moore, R.W. Osterstock, B.K. Replogle,
H.S. Samsel, C.L. Setzer, E.M. Shoemaker, H.K. Stager, L.R. Stieff, C.M. Tschanz, and J.D. Vogel, and by engineers C.E. Blunt, M.F. Gilkey, W.T. Millar, T.W. Oster, E.V. Reinhardt, J.I. Schumacher, and J.E. Warner. D.C. Duncan, W.L. Stokes, and D.A. Phoenix, USGS, made some geologic studies in the district during this period.

Geologic work in the district was expanded and drilling programs were continued in September 1953 under the supervision of D.R. Shawe. Some of the drilling in the Disappointment Valley area in early 1956 was supervised by D.A. Phoenix. Other geologists who worked in the district from 1953 into 1958 are N.L. Archbold, G.C. Simmons, E.L. Boudette, W.B. Rogers, W.B. Gazdik, W.L. Emerick, J.A. Madsen, O.T. Marsh, R.L. McDonald, W.R. Barton, Jr., J.J. Connor, and O.B. Raup. Engineers who aided the project during this period were Clyde Duren, C.N. Brown, and John Miller. Geologic studies and exploratory drilling in the district during the period 1953-1958 were done under the general direction of Harold Kirkemo and J.W. Hasler.

Appreciation is extended to many individuals and companies engaged in mining, and mineral, oil, and gas exploration in the district, for information, cooperation, or permission to publish data. Among these are John Motica, John Emerson, Milton Genes, Bruce Hanson, and other representatives of Union Carbide Nuclear Co. (formerly United States Vanadium Corp.), R.J. Wright, A.M. Mastrovich, Dick Darnell, and other representatives of Climax Uranium Co. (American Metals Climax, Inc.), Dennis Viles, Page Edwards, and other representatives of Vanadium Corporation of America, Donald Hoffman, Donald Manke, and other representatives of Hunt Oil Co., Leroy Hemphill, C.H. Dulaney, Frank H. Macpherson, Jim Hershel, and other representatives of Dulaney Mining Co., Henry Holling of Holling Mining Co., C.G. Ortmayer and Frank Terman of Ortmayer Mining Co., Irving Rapaport of Four Corners Exploration Co., C.H. Reynolds of Reynolds Mining Co., Robert D. Fulton of Newmont Mining Co., Arthur Canfield of Canfield Mines, Melvin C. Bowles of Equitable Uranium Corp., Fallas M. Kelly and other representatives of Green River Oil and Uranium Co., Ray Fahnlender of United Uranium Corp., T.J. Weaver of Ajax Uranium Co., T.H. Skidmore of Skidmore Mining Co., Messrs. Knapp and Grover Williams of San Juan Development Co., Mr. Winger of Rosario Mining Co., William Gillespie of Uranium Metals Co., Charles Butler of Duncan Mining Co., as well as numerous representatives of Phillips Petroleum Co., The California Co., Superior Oil Co., Marcey Exploration Co., Carter Oil Co., Continental Oil Co., Bowles Heflin Mining Co., Johannsen and Kelly Mining Co., Bolles Brothers of Grand Junction, the Sitton brothers of Dove Creek, Fritz-Erickson Mining Co., Messrs. Gomez and Blaire Burwell of Egnar, Marion R. Watters of Dolores, W.D. Tripp Mining Co., Messrs. Davis and Goforth of Dove Creek, C. Eggers of Dove Creek, and Messrs. McCormick, Jim Knowles, Ernie Blair, and A.L. Wilhite.

Robert G. Coleman contributed much to the project by mineralogical studies and by valuable discussions in the field. W.D. Allen assisted in the compilation of data for a few weeks 
in 1960. Numerous colleagues, but in particular Donald G. Wyant during the early part of the investigations, provided valuable discussions that helped me clarify ideas of the origin of the uranium-vanadium deposits. Howard E. Bowers made extensive microscopic studies of grain mounts of heavy minerals, circa 1960, which materially aided recognition of different facies of the Slick Rock sedimentary rocks. Discussions of lead-isotope data with Leonid Neymark of USGS have been useful. Lorin Stieff's information and suggestions regarding lead isotopes have been especially helpful in developing my understanding of the Slick Rock ores. George Breit's many helpful discussions, as well as early critical reviews of unfinished parts of this manuscript, have clarified aspects of the geochemistry of the deposits, particularly the chemical character of fluids inferred to have been involved in ore deposition. Erroneous interpretations of technical aspects of lead isotopes and geochemistry in this report are mine. Virtually all of the illustrations (figures and plates) were digitized by Stephan Justice and funded by the USGS Energy Team under James Otton; and drafted by Joe and Alice Springfield of Springfield and Springfield. Thomas A. Steven provided important suggestions in a review of an unfinished version of part of this manuscript. Alfred T. Bush and George L. Breit of USGS formally reviewed the document, making significant suggestions to clarify descriptions and to improve quality of the data. Breit's suggestions for improving organization of the report have been especially helpful.

Finally, appreciation for support from two USGS funding sources is acknowledged. Following my retirement from USGS in 1995, I was able to continue unfinished work under the Emeritus Scientist program, including a Pecora Fellowship, during which time efforts on manuscript and illustration preparation of this report were carried on sporadically with other work. Following the recent (20062008) renewed impetus for nuclear-power generation in the U.S., and the greatly increased price of uranium, preparation of the report has been sustained to completion by a Bradley Scholarship.

\section{References}

Archbold, N.L., 1959, Relationship of carbonate cement to lithology and vanadium-uranium deposits in the Morrison Formation in southwestern Colorado: Economic Geology, v. 54, no. 4, p. 666-682.

Bell, Henry, III, 1950, Results of diamond-drill exploration and plans for additional drilling in the Legin group area, San Miguel County, Colorado: U.S. Geological Survey Trace Elements Memorandum Report 113, 12 p.

Bell, Henry, III, 1953, Carnotite resources of the Spud Patch area, San Miguel County, Colorado: U.S. Geological Survey Trace Elements Investigations Report 286, 46 p.
Botinelly, Theodore, and Weeks, A.D., 1957, Mineralogic classification of uranium-vanadium deposits of the Colorado Plateau: U.S. Geological Survey Bulletin 1074-A, p. 1-5.

Bove, D.J., Hon, Ken, Budding, K.E., Slack, J.F., Snee, L.W., and Yeoman, P.A., 2001, Geochronology and geology of late Oligocene through Miocene volcanism and mineralization in the western San Juan Mountains, Colorado: U.S. Geological Survey Professional Paper 1642, 30 p.

Bowers, H.E., and Shawe, D.R., 1961, Heavy minerals as guides to uranium-vanadium ore deposits in the Slick Rock district, Colorado: U.S. Geological Survey Bulletin 1107-B, p. 169-218 (1962).

Breit, G.N., 1986, Geochemical study of authigenic minerals in the Salt Wash Member of the Morrison Formation, Slick Rock district, San Miguel County, Colorado: Colorado School of Mines, Ph.D. dissertation, Golden, Colo., $267 \mathrm{p}$.

Breit, G.N., and Goldhaber, M.B., 1995, Diagenesis of sandstone in the Morrison Formation within the Paradox Basin, in Huffman, A.C., Jr., Lund, W.R., and Godwin, L.H., Geology and resources of the Paradox Basin: Utah Geological Association Guidebook 25, p. 197-210.

Breit, G.N., Goldhaber, M.B., Shawe, D.R., and Simmons, E.C., 1990, Authigenic barite as an indicator of fluid movement through sandstones within the Colorado Plateau: Journal of Sedimentary Petrology, v. 60, p. 884-896.

Breit, G.N., and Meunier, J.D., 1990, Fluid inclusion and $\delta^{18} \mathrm{O}$, and $\mathrm{Sr}^{87} / \mathrm{Sr}^{86}$ evidence for the origin of fault-controlled copper mineralization, Lisbon Valley, Utah, and Slick Rock district, Colorado: Economic Geology, v. 85, p. 884-891.

Bush, A.L., Hilpert, L.S., and Trace, R.D., 1950, Carnotite resources of the Georgetown group of claims, San Miguel Country, Colorado: U.S. Geological Survey Trace Elements Investigations Report 116, 26 p.

Bush, A.L., and Stager, H.K., 1956, Accuracy of ore-reserve estimates for uranium-vanadium deposits on the Colorado Plateau: U.S. Geological Survey Bulletin 1030-D, p. 131-148.

Cadigan, R.A., 1967, Petrology of the Morrison Formation in the Colorado Plateau region: U.S. Geological Survey Professional Paper 556, 113 p.

Coffin, R.C., 1921, Radium, uranium, and vanadium deposits of southwestern Colorado: Colorado Geological Survey Bulletin 16, $231 \mathrm{p}$.

Coleman, R.G., and Delevaux, Maryse, 1957, Occurrence of selenium in sulfides from some sedimentary rocks of the Western United States: Economic Geology, v. 52, p. 499-527. 
Craig, L.C., Holmes, G.H., Cadigan, R.A., Freeman, V.L., Mullens, T.E., and Weir, G.W., 1955, Stratigraphy of the Morrison and related formations, Colorado Plateau region, a preliminary report: U.S. Geological Survey Bulletin 1009E, p. $125-168$.

Fischer, R.P., 1942, Vanadium deposits of Colorado and Utah, a preliminary report: U.S. Geological Survey Bulletin 936P, p. 363-394.

Fischer, R.P., and Hilpert, L.S., 1952, Geology of the Uravan mineral belt: U.S. Geological Survey Bulletin 988-A, p. 1-13.

Fleck, Herman, and Haldane, W.G., 1907, A study of the uranium and vanadium belts of southern Colorado: Colorado Bureau of Mines Report 1905-6, p. 47-124.

Gaines, R.V., Skinner, H.C.C., Foord, E.E., Mason, Brian, and Rozenzweig, Abraham, 1997, Dana's new mineralogy; The system of mineralogy of James Dwight Dana and Edward Salisbury Dana, 8th edition: John Wiley and Sons, Inc., New York, NY, United States, 1819 p.

Gruner, J.W., Rosenzweig, Abraham, and Smith, D.K., Jr., 1954, Annual report for April 1, 1953 to March 31, 1954: U.S. Atomic Energy Commission Report RME-3094, 37 p., issued by U.S. Atomic Energy Commission Technical Information Services, Oak Ridge, Tenn.

Hansley, P.L., and Spirakis, C.S., 1992, Organic matter diagenesis as the key to a unifying theory for the genesis of tabular uranium-vanadium deposits in the Morrison Formation, Colorado Plateau: Economic Geology, v. 87, p. 352-365.

Hess, F.L., 1933, Uranium, vanadium, radium, gold, silver and molybdenum sedimentary deposits, in The Committee on the Lindgren Volume, Finch, J.W., Chairman, Bateman, A.M., Butler, B.S., Loughlin, G.F., McLaughlin, D.H., and Singewald, J.T., Jr., eds, Ore deposits of the western states (Lindgren volume): New York, American Institute of Mining and Metallurgical Engineers, p. 450-481.

Huleatt, W.P., Hazen, S.W., Jr., and Traver, M.M., Jr., 1946, Exploration of vanadium region of western Colorado and eastern Utah: U.S. Bureau of Mines Report of Investigations $3930,30 \mathrm{p}$.

Isachsen, Y.W., and Evensen, C.G., 1956, Geology of uranium deposits of the Shinarump and Chinle Formations on the Colorado Plateau, in Page, L.R., Stocking, H.E., and Smith, H.B., compilers, Contributions to the geology of uranium and thorium by the United States Geological Survey and Atomic Energy Commission for the United Nations International Conference on Peaceful Uses of Atomic Energy, Geneva, Switzerland, 1955: U.S. Geological Survey Professional Paper 300, p. 263-280.
Jensen, M.L., 1958, Sulfur isotopes and the origin of sandstone-type uranium deposits: Economic Geology, v. 53 , no. 5, p. 598-616.

Keller, W.D., 1962, Clay minerals in the Morrison Formation of the Colorado Plateau: U.S. Geological Survey Bulletin $1150,90 \mathrm{p}$.

Kelley, J.C., 1958, Tectonics of the region of the Paradox basin, in Intermountain Association of Petroleum Geologists Guidebook 9th Annual Field Conference, Uinta Basin, 1958: p. 31-38.

Kimbal, Gordon, 1904, Discovery of carnotite: Engineering and Mining Journal, v. 77, p. 956.

Langmuir, Donald, 1978, Uranium solution mineral equilibria at low temperatures with application to sedimentary ore deposits: Geochimica et Cosmochimica Acta, v. 42, p. 547-569.

Ludwig, K.R., Simmons, K.R., and Webster, J.D., 1984, U-Pb isotope systematics and apparent ages of uranium ores, Ambrosia Lake and Smith Lake districts, Grants mineral belt, New Mexico: Economic Geology, v. 79, p. 323-337.

MacIntyre, T.J., 2004, Fault-controlled hydrocarbon-related bleaching and sediment-hosted copper mineralization of the Jurassic Wingate Sandstone at the Cashin mine, Montrose County, Colorado, Colorado School of Mines, Master's thesis, Golden, Colo., 216 p.

Moore, R.B., and Kithil, K.L., 1916, A preliminary report on uranium, radium, and vanadium: U.S. Bureau of Mines Bulletin 70, $101 \mathrm{p}$.

Nelson, S.T., Heizler, M.T., and Davidson, J.P., 1992, New ${ }^{40} \mathrm{Ar} /{ }^{39} \mathrm{Ar}$ ages of intrusive rocks from Henry and La Sal Mountains, Utah: Utah Geological Survey Miscellaneous Publication 92-2, 24 p.

Petersen, Fred, 1988, Stratigraphy and nomenclature of Middle and Upper Jurassic rocks, western Colorado Plateau, Utah and Arizona: U.S. Geological Survey Bulletin 1633B, p. 13-56.

Rogers, W.B., and Shawe, D.R., 1962, Exploration for uranium-vanadium deposits by the U.S. Geological Survey 1948-56 in western Disappointment Valley area, Slick Rock district, San Miguel County, Colorado (West Half) (East Half): U.S. Geological Survey Mineral Investigations Field Studies Map MF-241, scale 1:12,000.

Rosholt, J.N., Butler, A.P., Garner, E.L., and Shields, W.R., 1965a, Isotopic fractionation of uranium in sandstone, Powder River Basin, Wyoming, and Slick Rock district, Colorado: Economic Geology, v. 60, p. 199-213. 
Rosholt, J.N., Tatsumoto, M., and Dooley, J.R., Jr, 1965b, Radioactive disequilibrium in sandstone, Powder River Basin, Wyoming, and Slick Rock district, Colorado: Economic Geology, v. 60, p. 477-484.

Shawe, D.R., 1956a, Significance of roll ore bodies in genesis of uranium-vanadium deposits on the Colorado Plateau, in United Nations, Geology of uranium and thorium: International Conference on Peaceful Uses of Atomic Energy, Geneva, August, 1955, Proceedings, v. 6, p. 335337; slightly revised, in Page, L.R., Contributions to the geology of uranium and thorium: U.S. Geological Survey Professional Paper 300, p. 239-241.

Shawe, D.R., 1956b, Alteration related to Colorado Plateau ore deposits (abs.): Geological Society of America Bulletin, v. 67 , no. 12 , pt. 2 , p. $1732-1733$.

Shawe, D.R., 1962, Localization of the Uravan mineral belt by sedimentation, in Short papers in geology and hydrology: U.S. Geological Survey Professional Paper 450-C, p. C6-C8.

Shawe, D.R., 1966, Zonal distribution of elements in some uranium-vanadium roll and tabular ore bodies on the Colorado Plateau, in Geological Survey Research 1966: U.S. Geological Survey Professional Paper 550-B, p. B169B175.

Shawe, D.R., 1968, Petrography of sedimentary rocks in the Slick Rock district, San Miguel and Dolores Counties, Colorado: U.S. Geological Survey Professional Paper 576-B, 34 p.

Shawe, D.R., 1969, Possible exploration targets for uranium deposits, south end of the Uravan mineral belt, ColoradoUtah, in Geological Survey Research 1969, Chapter B: U.S. Geological Survey Professional Paper 650-B, p. B73B76.

Shawe, D.R., 1970, Structure of the Slick Rock district and vicinity, San Miguel and Dolores Counties, Colorado: U.S. Geological Survey Professional Paper 576-C, 18 p.

Shawe, D.R., 1976a, Sedimentary rock alteration in the Slick Rock district, San Miguel and Dolores Counties, Colorado: U.S. Geological Survey Professional Paper 576-D, 51 p.

Shawe, D.R., 1976b, Geologic history of the Slick Rock district and vicinity, San Miguel and Dolores Counties, Colorado: U.S. Geological Survey Professional Paper 576E, 19 p.

Shawe, D.R., Archbold, N.L., and Simmons, G.C., 1959, Geology and uranium-vanadium deposits of the Slick Rock district, San Miguel and Dolores Counties, Colorado: Economic Geology, v. 54, no. 3, p. 395-415.
Shawe, D.R., Nash, J.T., and Chenoweth, W.L., 1991, Uranium and vanadium deposits, in Gluskoter, H.J., Rice, D.D., and Taylor, R.B., eds., Economic Geology, U.S.: The Geology of North America, v. P-2, The Decade of North American Geology, The Geological Society of America, Inc., Boulder, Colo., p. 103-124.

Shawe, D.R., Simmons, G.C., and Archbold, N.L., 1968, Stratigraphy of the Slick Rock district and vicinity, San Miguel and Dolores Counties, Colorado: U.S. Geological Survey Professional Paper 576-A, 108 p. (1969).

Shoemaker, E.M., Miesch, A.T., Newman, W.L., and Riley, L.B., 1959, Elemental composition of the sandstone-type deposits, pt. 3 in Garrels, R.M., and Larsen, E.S., compilers, Geochemistry and mineralogy of the Colorado Plateau uranium ores: U.S Geological Survey Professional Paper 320, p. 25-54.

Sneed, M.C, and Maynard, J.L., 1944, General college chemistry: D. Van Nostrand Company, Inc., New York, 861 p.

Spirakis, C.S., 1996, The roles of organic matter in the formation of uranium deposits in sedimentary rocks: Ore Geology Reviews, v. 11, issues 1-3, p. 53-69.

Steen, C.A., Dix, D.P., Jr., Hazen, S.W., Jr., and McLellan, R.R., 1953, Uranium-mining operations of the Utex Exploration Company in the Big Indian district, San Juan County, Utah: U.S. Bureau of Mines Information Circular 7669, $13 \mathrm{p}$.

Stern, T.W., Newell, M.F., Kistler, R.W., and Shawe, D.R., 1965, Zircon uranium-lead and thorium-lead ages and mineral potassium-argon ages of La Sal Mountains rocks, Utah: Journal of Geophysical Research, v. 70, no. 6, p. 1503-1507.

Stewart, J.H., Poole, F.G., and Wilson, R.F., 1972, Stratigraphy and origin of the Chinle Formation and related Upper Triassic strata in the Colorado Plateau region: U.S. Geological Survey Professional Paper 690, 336 p.

Stewart, J.H., Williams, G.A., Albee, H.F., and Raup, O.B, 1959, Stratigraphy of Triassic and associated formations in part of the Colorado Plateau region: U.S. Geological Survey Bulletin 1046-Q, p. 487-576.

Stieff, L.R., and Stern, T.W., 1953, Lead-uranium ages of some uraninites from Triassic and Jurassic sedimentary rocks of the Colorado Plateau: American Mineralogist, v. 38, no. 3-4, p. 359-360.

Stieff, L.R., Stern, T.W., and Milkey, R.G., 1953, A preliminary determination of the age of some uranium ores of the Colorado Plateau by the lead-uranium method: U.S. Geological Survey Circular 271, 19 p. 
Swanson, V.E., and Palacas, J.G., 1965, Humate in coastal sands of northwest Florida: U.S. Geological Survey Bulletin 1214-B, p. B1-B29.

Trace, R.D., 1950, Carnotite resources in the Radium group area, San Miguel County, Colorado: U.S. Geological Survey Trace Elements Investigations Report 113, 29 p.

Turner, C.E., and Fishman, N.S., 1991, Jurassic Lake T'oo'doochi'; a large alkaline , saline lake, Morrison Formation, eastern Colorado Plateau: Geological Society of America v. 103, no. 4, p. 538-558.

Tyler, Noel, and Ethridge, F.G., 1985, Depositional setting of the Salt Wash Member of the Morrison Formation: Journal of Sedimentary Petrology, v. 53, p. 67-82.

Tyrrell, G.W., 1926, The principles of petrology: E.P. Dutton and Company Inc., New York, 349 p.

Waters, A.C. and Granger, H.C., 1953, Volcanic debris in uraniferous sandstones and its possible bearing on the origin and precipitation of uranium: U.S. Geological Survey Circular 224, 26 p.

Weeks, A.D., 1956, Mineralogy and oxidation of the Colorado Plateau uranium ores, in Page, L.R., Contributions to the geology of uranium and thorium: U.S. Geological Survey Professional Paper 300, p. 181-193.

Weeks, A.D., Coleman, R.G., and Thompson, M.E., 1959, in Garrels, R.M., and Larsen, E.S., Jr., Summary of the ore mineralogy, pt. 5, Geochemistry and mineralogy of the Colorado Plateau uranium ores: U.S. Geological Survey Professional Paper 320, p. 65-79.

Weir, G.W., and Puffett, W.P., 1981, Stratigraphy and structural geology and uranium-vanadium and copper deposits of the Lisbon Valley area, Utah- Colorado: U.S. Geological Survey Open-File Report 81-39, 292 p.

Zartman, R.E., 1974, Lead isotopic provinces in the Cordillera of the western United States and their geologic significance: Economic Geology, v. 69, p. 792-805. 


\title{
Appendix A
}

\section{Uranium-Vanadium Production}

\author{
By William L. Chenoweth
}

Uranium-vanadium production in the United States up to about 1985 was summarized by W.L. Chenoweth (Shawe, Nash, and Chenoweth, 1991), including production in the Slick Rock district up to 1978. Ore production data available to the public were recorded by the Atomic Energy Commission (AEC) until 1970 at which time the AEC, the Department of Energy (DOE), and Energy Resources D - Administration (ERDA) recorded production data on a "company confidential" basis, so that data on individual mines were not released. Slick Rock district production is updated here to the latest period of mining to mid-1983, and these data are included in the present summary. In addition, production data are organized by specific areas defined by mine groups (SM) and Mineral Leases (ML). These data are given in tables I and II. Table III provides year-to-year production and grade data for uranium and vanadium from 1948 to 1983.

Table I. Uranium-Vanadium Production, by Areas, in the Slick Rock District.

[Areas are outlined on pl. 3, which shows groups as designated by the AEC, for example, SM-1, of mine locations in the district. Bracketed areas lie outside the Slick Rock district proper, to the northeast. Individual mine locations known as of 1968 are shown on pl. 1, Shawe and others, 1968].

Production is summarized by mine groups; within groups the principal mines are listed, and total production of the group, in tons of ore, is given.

\begin{tabular}{|c|c|c|c|}
\hline Group & & $\begin{array}{l}\text { Total tons of ore and } \\
\text { interval of production }\end{array}$ & Principal mine(s) \\
\hline SM-1, & Summit Canyon & $1,748,900(1959-1980)$ & Deremo \\
\hline SM-3, & $\begin{array}{l}\text { Slick Rock- } \\
\text { Dolores River }\end{array}$ & $755,800(1952-1980)$ & $\begin{array}{l}\text { Burro mines } \\
\text { North Burro } \\
\text { Middle group } \\
\text { Ellison } \\
\text { Hawkeye } \\
\text { Grass Flat } \\
\text { Vanadium } \\
\text { Little Yolande }\end{array}$ \\
\hline
\end{tabular}


Table I. Uranium-Vanadium Production, by Areas, in the Slick Rock District.-Continued

\begin{tabular}{|c|c|c|c|}
\hline Group & & $\begin{array}{l}\text { Total tons of ore and } \\
\text { interval of production }\end{array}$ & Principal mine(s) \\
\hline SM-4, & $\begin{array}{l}\text { South Gypsum } \\
\text { Ridge, Big } \\
\text { Gypsum Creek }\end{array}$ & $379,600(1960-1980)$ & $\begin{array}{l}\text { Carnation } \\
\text { G M G } \\
\text { Magpie } 2 \\
\text { Sunday } \\
\text { Uncle Sam }\end{array}$ \\
\hline [SM-7, & $\begin{array}{l}\text { South Wedding Bell, } \\
\text { Radium Mountain, } \\
\text { Dolores River, } \\
\text { Mary Jane Draw }\end{array}$ & $122,500(1948-1980)$ & $\begin{array}{l}\text { Rim Rock mines } \\
\text { Burro Point } \\
\text { Ground Hog } \\
\text { Main Street } \\
\text { Mary Jane } \\
\text { Jack Knife } \\
\text { Hot Shot }\end{array}$ \\
\hline SM-8, & $\begin{array}{l}\text { Ownbey group, } \\
\text { Summit Canyon }\end{array}$ & $120,800(1949-1979)$ & $\begin{array}{l}\text { Frankie } \\
\text { Hank } \\
\text { Easton B } \\
\text { Michael Bray } \\
\text { Ann }\end{array}$ \\
\hline [SM-10, & $\begin{array}{l}\text { Hamm Canyon, } \\
\text { Big Gypsum Creek }\end{array}$ & $76,200(1948-1980)$ & $\begin{array}{l}\text { Mexico Group } \\
\text { Magpie } \\
\text { Lonesome } \\
\text { Lookout } \\
\text { Breezy } \\
\text { Chilli } \\
\text { Red Horse } \\
\text { Murietta } \\
\text { Rainy Day }\end{array}$ \\
\hline
\end{tabular}


Table I. Uranium-Vanadium Production, by Areas, in the Slick Rock District.-Continued

\begin{tabular}{|c|c|c|c|}
\hline Group & & $\begin{array}{l}\text { Total tons of ore and } \\
\text { interval of production }\end{array}$ & Principal mine(s) \\
\hline SM-11, & $\begin{array}{l}\text { North Gypsum Ridge } \\
\text { Big Gypsum Creek }\end{array}$ & $73,000(1948-1980)$ & $\begin{array}{l}\text { Early Morn } \\
\text { Long Ridge } \\
\text { Vanadium } \\
\text { Pond } \\
\text { Wilmarth } \\
\text { Windswept } \\
\text { Tiny } \\
\text { Two Bar }\end{array}$ \\
\hline SM-12, & $\begin{array}{l}\text { Veta Mad, } \\
\text { Georgetown, } \\
\text { Dolores River }\end{array}$ & $72,700(1951-1980)$ & $\begin{array}{l}\text { Veta Glad } \\
\text { Veta Mad } \\
\text { Georgeto }\end{array}$ \\
\hline SM-13, & $\begin{array}{l}\text { Spud Patch, } \\
\text { Blue Canyon }\end{array}$ & 37,700 (1948-1979) & $\begin{array}{l}\text { Spud Patch } \\
\text { Moqui Jug } \\
\text { Depression } \\
\text { Norma Jean } \\
\text { Marne }\end{array}$ \\
\hline SM-14, & $\begin{array}{l}\text { Upper group, } \\
\text { Bush Canyon, } \\
\text { Dolores River }\end{array}$ & $35,300(1950-1979)$ & $\begin{array}{l}\text { Upper group } \\
\text { Canyon View } \\
\text { Black Fox } \\
\text { Grant } \\
\text { Golden Rod } \\
\text { Neomie D }\end{array}$ \\
\hline SM-15, & $\begin{array}{l}\text { Joe Davis Hill, } \\
\text { Dolores River }\end{array}$ & $35,800(1948-1980)$ & $\begin{array}{l}\text { Fox } \\
\text { Horseshoe mines } \\
\text { Roy Lee } \\
\text { Parrot } \\
\text { Mucho Grande } \\
\text { Red Rock mines } \\
\text { Wally } \\
\text { SB }\end{array}$ \\
\hline SM-16, & $\begin{array}{l}\text { Charles T area, } \\
\text { Summit Canyon }\end{array}$ & $22,100(1950-1979)$ & $\begin{array}{l}\text { Charles T. } \\
\text { Fraction }\end{array}$ \\
\hline$[\mathrm{SM}-17$, & $\begin{array}{l}\text { Pitchfork area, } \\
\text { Big Gypsum Creek }\end{array}$ & $20,400(1946-1968)$ & $\begin{array}{l}\text { Pitchfork } \\
\text { Gyp Valley }\end{array}$ \\
\hline SM-18, & $\begin{array}{l}\text { Island Mesa, } \\
\text { McIntyre Canyon }\end{array}$ & $11,700(1949-1979)$ & $\begin{array}{l}\text { Empire roup } \\
\text { Civit Cat } \\
\text { Happy Jack } \\
\text { Lost } \\
\text { Vanadium Queen }\end{array}$ \\
\hline [SM-19, & $\begin{array}{l}\text { Bald Eagle mine, } \\
\text { Big Gypsum Creek }\end{array}$ & 7,700 (1948-1969) & $\begin{array}{l}\text { Bald Eagle } \\
\text { Keystone }\end{array}$ \\
\hline SM-20, & $\begin{array}{l}\text { Mercantile area, } \\
\text { Summit Canyon }\end{array}$ & $6,500(1949-1980)$ & $\begin{array}{l}\text { Mercantile mines } \\
\text { Letty Jones }\end{array}$ \\
\hline [SM-21, & $\begin{array}{l}\text { Little Gypsum Valley } \\
\text { Southeast, Little } \\
\text { Gypsum Creek }\end{array}$ & $5,300(1951-1964)$ & $\begin{array}{l}\text { Golden Eagle } \\
\text { Giant } \\
\text { Gyp Lease }\end{array}$ \\
\hline$[\mathrm{SM}-22$, & $\begin{array}{l}\text { North Gypsum Ridge, } \\
\text { Big Gypsum Creek }\end{array}$ & $3,800(1948-1968)$ & $\begin{array}{l}\text { Cliff Dweller } \\
\text { Rambler }\end{array}$ \\
\hline
\end{tabular}


Table I. Uranium-Vanadium Production, by Areas, in the Slick Rock District.-Continued

\begin{tabular}{|c|c|c|c|}
\hline Group & & $\begin{array}{l}\text { Total tons of ore and } \\
\text { interval of production }\end{array}$ & Principal mine(s) \\
\hline SM-23, & $\begin{array}{l}\text { Horse Range Mesa } \\
\text { McIntyre Canyon }\end{array}$ & $3,600(1949-1956)$ & $\begin{array}{l}\text { La Salle } \\
\text { Pinto } \\
\text { Yellow Girl }\end{array}$ \\
\hline SM-24, & Upper group mines & $3,200(1949-1975)$ & $\begin{array}{l}\text { Full Moon mines } \\
\text { Queen of Spades }\end{array}$ \\
\hline SM-25, & $\begin{array}{l}\text { Grassy Hills, } \\
\text { Dolores River }\end{array}$ & $1,900(1955-1956)$ & Prospectors Fortune \\
\hline [SM-26, & $\begin{array}{l}\text { Big Gypsum Valley } \\
\text { northwest, } \\
\text { Dolores River }\end{array}$ & $1,600(1951-1977)$ & $\begin{array}{l}\text { Valley View } \\
\text { Riverview } \\
\text { Sears }\end{array}$ \\
\hline SM-27, & $\begin{array}{l}\text { Gyp Gap southeast, } \\
\text { Big Gypsum Creek }\end{array}$ & $1,200(1951-1966)$ & $\begin{array}{l}\text { Victor } \\
\text { Penju }\end{array}$ \\
\hline SM-28, & $\begin{array}{l}\text { Ned group, } \\
\text { Dolores River }\end{array}$ & $1,000(1952-1954)$ & Ned group \\
\hline SM-29, & $\begin{array}{l}\text { Gyp Gap northwest, } \\
\text { Dolores River }\end{array}$ & $700(1949-1958)$ & $\begin{array}{l}\text { Big Chief } \\
\text { Brown Mule }\end{array}$ \\
\hline SM-30, & $\begin{array}{l}\text { Stevens Canyon, } \\
\text { Summit Canyon }\end{array}$ & $200(1948-1950)$ & $\begin{array}{l}\text { Mayflower } \\
\text { Radium } 1\end{array}$ \\
\hline
\end{tabular}


Table II. Mineral Production from Mineral Leases.

The U.S. Department of Energy (DOE) currently controls 25,000 acres of land in southwestern Colorado as the result of the Mineral Leasing Program. In the late 1940s and early 1950s, lands where the Atomic Energy Commission (AEC) and USGS planned exploratory drilling were withdrawn from mineral entry by Public Land Orders issued by the Bureau of Land Management (BLM). The AEC also acquired claims in the Slick Rock area and Calamity Mesa from the Union Mines Development Corporation, a contractor for the U.S. Army's Manhattan Engineer District.

When uranium ore reserves were discovered by the drilling projects, AEC contacted private companies that were mining in the adjacent area to determine if they were interested in leasing the land to develop and mine uranium needed for the Cold War. Lands where no uranium ore bodies were located were returned to the Public Domain. Leases specified a royalty on the ore produced. During the period 1948-1962 a total of 48 leases were issued by the Grand Junction Office of AEC. All were in southwestern Colorado with the exceptions of one in Arizona and three in Utah. Leases were identified with an ML (Mineral Lease) number. In 1962, all of the still operating leases were cancelled by the AEC as the agency began to reduce its uranium procurement program. Royalties paid to the government under this program totaled $\$ 5,890,391$.

Because of depressed economic conditions in the mining communities in western Colorado and eastern Utah in the late 1960s and early 1970s, the AEC was asked to reactivate its mineral leasing program. A total of 27 tracts were proposed for leasing. All were in Colorado with the exceptions of one in New Mexico and three in Utah. All of these tracts had a new numbering system that consisted of state, area, and number. For example, C-SR-10 was tract number 10 in the Slick Rock area of Colorado. Of the original 27 tracts, 15 were divided into 2 or 3 tracts, making a total of 43 offered at sealed bid sales. The bids were opened at three separate sales in April, May, and July 1974. In 1977 the DOE, as successor agency to the AEC, became responsible for the leases. Currently (2008), twelve leases are still in effect, including four in the Slick Rock area. The lands in New Mexico and Utah have been reclaimed and returned to the BLM. In Colorado the cancelled leases were reclaimed and made available for later leasing. On March 7, 2008, the DOE announced a third leasing program, including seven tracts in the Slick Rock district. After close of bidding on May 15, 2008, five companies were the high bidders on six Slick Rock tracts. One tract received no bids. The winning royalties ranged from 7.67 percent to 22.30 percent. Additional leasing information may be obtained at www.lm.doe.gov.

The data in the following table are listed by AEC Mineral Lease (ML) numbers. Production data for individual leases are given, by year, by dry tons of ore, and by U3O8 grade (percent). Also provided are total tons per lease, average U3O8 grade, and average V2O5 grade. In the period 19491962, a total of about 419,646 tons of ore was produced from AEC leases. Source of data is U.S. Atomic Energy Commission, 1964, Summary of AEC mineral lease program, 19421962: U.S. Atomic Energy Commission unpublished report, $14 \mathrm{p}$.

\begin{tabular}{|c|c|c|c|c|c|}
\hline Property & Lessee & Year & Dry tons & $\begin{array}{l}\text { Production } \\
\text { Percent } \\
\mathbf{U}_{3} \mathbf{O}_{8}\end{array}$ & $\begin{array}{l}\text { Percent } \\
\mathbf{V}_{2} \mathbf{O}_{5}\end{array}$ \\
\hline ML-1, King No. 2 Sam & Tom Skidmore & $\begin{array}{l}1949 \\
1950 \\
1951 \\
1952 \\
1953 \\
1954 \\
1955 \\
1956 \\
1957 \\
1958 \\
1959 \\
1960 \\
1961 \\
1962\end{array}$ & $\begin{array}{r}1,296 \\
1,928 \\
2,679 \\
9,641 \\
10,015 \\
5,174 \\
3,020 \\
3,206 \\
2,709 \\
1,929 \\
1,490 \\
4,525 \\
931 \\
181\end{array}$ & $\begin{array}{l}0.44 \\
0.42 \\
0.40 \\
0.30 \\
0.28 \\
0.29 \\
0.38 \\
0.29 \\
0.33 \\
0.23 \\
0.30 \\
0.24 \\
0.17 \\
0.23\end{array}$ & \\
\hline Total & & & 48,724 & 0.31 & 2.20 \\
\hline
\end{tabular}


Table II. Mineral Production from Mineral Leases.-Continued

\begin{tabular}{|c|c|c|c|c|c|}
\hline Property & Lessee & Year & Dry tons & $\begin{array}{l}\text { Production } \\
\text { Percent } \\
\mathbf{U}_{3} \mathbf{O}_{8}\end{array}$ & $\begin{array}{l}\text { Percent } \\
\mathbf{V}_{2} \mathbf{O}_{5}\end{array}$ \\
\hline $\begin{array}{l}\text { ML-2, Frenchy, } \\
\text { King, May, } \\
\text { Cowgirl Co. }\end{array}$ & $\begin{array}{l}\text { Minerals } \\
\text { Engineering }\end{array}$ & $\begin{array}{l}1949 \\
1950 \\
1951 \\
1952\end{array}$ & $\begin{array}{r}893 \\
4,188 \\
3,934 \\
2,117\end{array}$ & $\begin{array}{l}0.35 \\
0.29 \\
0.32 \\
0.31\end{array}$ & \\
\hline Total & & & 11,132 & 0.32 & 2.33 \\
\hline $\begin{array}{l}\text { ML-3, Nucles, } \\
\text { Easton B, } \\
\text { Michael Bray } \\
\text { Nos.1 \& } 2\end{array}$ & $\begin{array}{l}\text { William A. } \\
\text { Hooten }\end{array}$ & $\begin{array}{l}1949 \\
1950\end{array}$ & $\begin{array}{l}944 \\
918\end{array}$ & $\begin{array}{l}0.32 \\
0.21\end{array}$ & \\
\hline Total & & & 1,862 & 0.26 & 1.89 \\
\hline $\begin{array}{l}\text { ML-4, Tomboy, Beth, } \\
\text { Independence, } \\
\text { Avoca, Ike } \\
\text { Nos.1 \& } 2 \\
\text { Mercantile, } \\
\text { Sibley, Park, } \\
\text { Brighton, } \\
\text { Nucles, } \\
\text { Easton B, } \\
\text { Michael Bray, } \\
\text { Ann Nos. 1 \& 2 } \\
\text { fraction adjacen } \\
\text { Ann 2, Hawk N } \\
\text { and Frankie No }\end{array}$ & $\begin{array}{l}\text { Dulaney } \\
\text { Mining Co. }\end{array}$ & $\begin{array}{l}1949 \\
1950 \\
\\
1951 \\
1952 \\
1953 \\
1954 \\
1955 \\
1956 \\
1957 \\
1958 \\
1959\end{array}$ & $\begin{array}{r}1,820 \\
4,854 \\
\\
8,059 \\
4,918 \\
23,767 \\
19,078 \\
19,027 \\
23,054 \\
4,769 \\
3,326 \\
1,221\end{array}$ & $\begin{array}{l}0.38 \\
0.39 \\
\\
0.20 \\
0.28 \\
0.33 \\
0.26 \\
0.31 \\
0.36 \\
0.34 \\
0.40 \\
0.65\end{array}$ & \\
\hline Total & & & 113,893 & 0.32 & 1.35 \\
\hline $\begin{array}{l}\text { ML-5, Charles T. } \\
\text { Nos. } 2 \& 4, \\
\text { Sunflower, } \\
\text { Pretty Boy }\end{array}$ & $\begin{array}{l}\text { John B. } \\
\text { Crowley }\end{array}$ & $\begin{array}{l}1949 \\
1950 \\
1951 \\
1952\end{array}$ & $\begin{array}{l}212 \\
3,400 \\
4,485 \\
1,393\end{array}$ & $\begin{array}{l}0.24 \\
0.51 \\
0.23 \\
0.33\end{array}$ & \\
\hline Total & & & 9,490 & 0.34 & 1.44 \\
\hline $\begin{array}{l}\text { ML-6, Cougar, } \\
\text { Last Chance, } \\
\text { Rainbow, } \\
\text { Little Mariel, } \\
\text { Chico, Lower } \\
\text { Fraction }\end{array}$ & $\begin{array}{l}\text { Henry } \\
\text { Holling }\end{array}$ & $\begin{array}{l}1949 \\
1950 \\
1951 \\
1952 \\
1953 \\
1954 \\
1955 \\
1956 \\
1957 \\
1958 \\
1959\end{array}$ & $\begin{array}{r}60 \\
1,538 \\
2,565 \\
2,574 \\
3,026 \\
2,611 \\
1,897 \\
2,455 \\
2,533 \\
5,360 \\
1,019\end{array}$ & $\begin{array}{l}0.53 \\
0.50 \\
0.51 \\
0.48 \\
0.48 \\
0.57 \\
0.35 \\
0.34 \\
0.40 \\
0.31 \\
0.37\end{array}$ & \\
\hline Total & & & 25,638 & 0.42 & 2.44 \\
\hline
\end{tabular}


Table II. Mineral Production from Mineral Leases.-Continued

\begin{tabular}{|c|c|c|c|c|c|}
\hline Property & Lessee & Year & Dry tons & $\begin{array}{l}\text { Production } \\
\text { Percent } \\
\mathbf{U}_{3} \mathbf{O}_{8}\end{array}$ & $\begin{array}{l}\text { Percent } \\
\mathrm{V}_{2} \mathrm{O}_{5}\end{array}$ \\
\hline $\begin{array}{c}\text { ML-7, Golden Rod, } \\
\text { Fraction } 3\end{array}$ & $\begin{array}{l}\text { Nielson } \\
\text { Larson }\end{array}$ & $\begin{array}{l}1950 \\
1951 \\
1952 \\
1953 \\
1954\end{array}$ & $\begin{array}{r}339 \\
2,717 \\
2,425 \\
4,415 \\
324\end{array}$ & $\begin{array}{l}0.32 \\
0.26 \\
0.22 \\
0.23 \\
0.19\end{array}$ & \\
\hline Total & & & 7,220 & 0.24 & 2.43 \\
\hline $\begin{array}{l}\text { ML-8, Fraction No. 1, } \\
\text { Fraction No. 5, } \\
\text { Summit, } \\
\text { Bennie T Nos. } 1 \\
\& 2, \text { Charles T } \\
\text { No. } 1\end{array}$ & $\begin{array}{l}\text { Arthur } \\
\text { Canfield }\end{array}$ & $\begin{array}{l}1950 \\
1951 \\
1952 \\
1953 \\
1954 \\
1955 \\
1956 \\
1957 \\
1958 \\
1959 \\
1960 \\
1961 \\
1962\end{array}$ & $\begin{array}{r}84 \\
1,415 \\
1,160 \\
1,545 \\
1,204 \\
1,137 \\
962 \\
322 \\
635 \\
1,242 \\
2,097 \\
1,720 \\
15\end{array}$ & $\begin{array}{l}0.48 \\
0.40 \\
0.34 \\
0.42 \\
0.34 \\
0.39 \\
0.57 \\
0.43 \\
0.32 \\
0.30 \\
0.34 \\
0.29 \\
0.37\end{array}$ & \\
\hline Total & & & 13,536 & 0.37 & 2.15 \\
\hline $\begin{array}{l}\text { ML-9, } \\
\text { Fraction No. 1, } \\
\text { Bennie T. No. 1, } \\
\text { Fraction No. 5, } \\
\text { Summit, } \\
\text { Bennie T. No. 2, } \\
\text { Charles T. No. } 2\end{array}$ & $\begin{array}{l}\text { Max W. } \\
\text { Barkley } \\
\& \text { Co. }\end{array}$ & $\begin{array}{l}1950 \\
1951 \\
1952\end{array}$ & $\begin{array}{r}23 \\
1,861 \\
1,671\end{array}$ & $\begin{array}{l}0.89 \\
0.42 \\
0.29\end{array}$ & \\
\hline Total & & & 3,555 & 0.36 & 2.62 \\
\hline $\begin{array}{l}\text { ML-12, Veta Mad } \\
\text { Veta Glad }\end{array}$ & W.A. Hopkins & $\begin{array}{l}1951 \\
1952 \\
1953\end{array}$ & $\begin{array}{r}865 \\
1,223 \\
2,157\end{array}$ & $\begin{array}{l}0.74 \\
0.42 \\
0.46\end{array}$ & \\
\hline Total & & & 4,246 & 0.50 & 2.37 \\
\hline $\begin{array}{c}\text { ML-15, Lease Block } \\
\text { adjacent to } \\
\text { TNT }\end{array}$ & $\begin{array}{l}\text { Vanadium Corp. } \\
\text { of America }\end{array}$ & $\begin{array}{l}1953 \\
1954 \\
1955 \\
1956 \\
1957 \\
1958 \\
1959 \\
1960 \\
1961\end{array}$ & $\begin{array}{r}61 \\
148 \\
---- \\
--- \\
832 \\
792 \\
865 \\
525 \\
25\end{array}$ & $\begin{array}{l}0.53 \\
0.56 \\
---- \\
--- \\
0.35 \\
0.27 \\
0.36 \\
0.28 \\
0.28\end{array}$ & \\
\hline Total & & & 3,248 & 0.32 & 1.63 \\
\hline
\end{tabular}


Table II. Mineral Production from Mineral Leases. - Continued

\begin{tabular}{|c|c|c|c|c|c|c|}
\hline Property & & Lessee & Year & Dry tons & $\begin{array}{l}\text { Production } \\
\text { Percent } \\
\mathbf{U}_{3} \mathbf{O}_{8}\end{array}$ & $\begin{array}{l}\text { Percent } \\
\mathrm{V}_{2} \mathrm{O}_{5}\end{array}$ \\
\hline \multirow[t]{2}{*}{ ML-16 } & $\begin{array}{l}\text { Lease Block } \\
\text { adjacent to } \\
\text { Falcon claim }\end{array}$ & $\begin{array}{l}\text { Kemph } \\
\text { \& Hirth }\end{array}$ & $\begin{array}{l}1951 \\
1952 \\
1953\end{array}$ & $\begin{array}{c}274 \\
--- \\
7\end{array}$ & $\begin{array}{l}0.23 \\
--- \\
0.36\end{array}$ & \\
\hline & Total & & & 281 & 0.23 & 2.35 \\
\hline \multirow[t]{2}{*}{ ML-17 } & Georgeto & Jack Turner & $\begin{array}{l}1951 \\
1952 \\
1953 \\
1954 \\
1955 \\
1956\end{array}$ & $\begin{array}{r}1,319 \\
2,832 \\
4,002 \\
4,163 \\
2,271 \\
14\end{array}$ & $\begin{array}{l}0.32 \\
0.39 \\
0.34 \\
0.41 \\
0.30 \\
0.50\end{array}$ & \\
\hline & Total & & & 13,415 & 0.36 & 1.75 \\
\hline \multirow[t]{2}{*}{ ML-18 } & $\begin{array}{c}\text { Eloisa \& } \\
\text { Otero }\end{array}$ & $\begin{array}{l}\text { William B. } \\
\text { McCormick }\end{array}$ & $\begin{array}{l}1952 \\
1953 \\
1954 \\
1955\end{array}$ & $\begin{array}{l}5,054 \\
2,530 \\
1,123 \\
1,219\end{array}$ & $\begin{array}{l}0.32 \\
0.29 \\
0.42 \\
0.21\end{array}$ & \\
\hline & Total & & & 9,926 & 0.29 & 1.75 \\
\hline \multicolumn{3}{|c|}{$\begin{array}{l}\text { ML-19, U.S. Vanadium Corp. } \\
\text { Lease made to include } \\
\text { all fractions of claims } \\
\text { not included in contract } \\
\text { AT }(05-1) 36\end{array}$} & 1955 & 97 & 0.26 & \\
\hline & Total & & & 97 & 0.26 & 1.26 \\
\hline ML-20 & $\begin{array}{l}\text { Knoll, } \\
\text { Helen, } \\
\text { Cacti, } \\
\text { Alice }\end{array}$ & $\begin{array}{l}\text { San Juan } \\
\text { Leasing Co. }\end{array}$ & $\begin{array}{l}1952 \\
1953 \\
1954 \\
1955\end{array}$ & $\begin{array}{l}3,931 \\
5,276 \\
3,687 \\
1,903\end{array}$ & $\begin{array}{l}0.30 \\
0.30 \\
0.34 \\
0.33\end{array}$ & \\
\hline & Total & & & 14,797 & 0.32 & 1.74 \\
\hline ML-21 & $\begin{array}{l}\text { Sunnyside, } \\
\text { Grant, } \\
\text { Big Four }\end{array}$ & $\begin{array}{l}\text { Baird Brothers, } \\
\text { Robinette, } \\
\text { \& Weese }\end{array}$ & 1952 & 1,798 & 0.26 & \\
\hline & Total & & & 1,798 & 0.26 & 1.79 \\
\hline ML-22 & $\begin{array}{l}\text { Golden Rod } \\
\text { Nos. } 1 \& 2, \\
\text { Fraction No. } 4\end{array}$ & $\begin{array}{l}\text { Jack } \\
\text { Fahrion }\end{array}$ & $\begin{array}{l}1952 \\
1953 \\
1954\end{array}$ & $\begin{array}{c}1,582 \\
437 \\
29\end{array}$ & $\begin{array}{l}0.25 \\
0.28 \\
0.21\end{array}$ & \\
\hline & Total & & & 2,048 & 0.26 & 2.35 \\
\hline
\end{tabular}


Table II. Mineral Production from Mineral Leases.-Continued

\begin{tabular}{|c|c|c|c|c|c|c|}
\hline \multicolumn{2}{|l|}{ Property } & \multirow{2}{*}{$\begin{array}{l}\text { Lessee } \\
\\
\begin{array}{c}\text { Johnson and } \\
\text { Hargrove }\end{array}\end{array}$} & $\begin{array}{l}\text { Year } \\
1952\end{array}$ & $\begin{array}{c}\text { Dry tons } \\
1,788\end{array}$ & \multirow{2}{*}{$\begin{array}{l}\text { Production } \\
\text { Percent } \\
\mathbf{U}_{\mathbf{3}} \mathbf{O}_{\mathbf{8}}\end{array}$} & \multirow[t]{2}{*}{$\begin{array}{l}\text { Percent } \\
\mathrm{V}_{2} \mathrm{O}_{5}\end{array}$} \\
\hline ML-25 & $\begin{array}{l}\text { Lease Block, } \\
\text { including } \\
\text { Golden Rod } \\
\text { No. } 5\end{array}$ & & $\begin{array}{l}1952 \\
1953 \\
1954\end{array}$ & $\begin{array}{r}1,788 \\
2,533 \\
161\end{array}$ & & \\
\hline & Total & & & 4,482 & 0.29 & 2.77 \\
\hline ML-27 & Ned claim & $\begin{array}{c}\text { Gamblin \& } \\
\text { Knowles }\end{array}$ & $\begin{array}{l}1952 \\
1953 \\
1954\end{array}$ & $\begin{array}{r}460 \\
436 \\
75\end{array}$ & $\begin{array}{l}0.18 \\
0.39 \\
0.33\end{array}$ & \\
\hline & Total & & & 970 & 0.20 & 1.21 \\
\hline ML-28 & Hawkeye & $\begin{array}{l}\text { R.L. Duncan \& } \\
\text { J.B. Sanchez }\end{array}$ & $\begin{array}{l}1952 \\
1953\end{array}$ & $\begin{array}{r}440 \\
1,016\end{array}$ & $\begin{array}{l}0.27 \\
0.35\end{array}$ & \\
\hline & Total & & & 1,456 & 0.33 & 1.12 \\
\hline ML-29 & $\begin{array}{l}\text { Frenchy, } \\
\text { King, } \\
\text { Cow Girl, } \\
\text { May }\end{array}$ & $\begin{array}{l}\text { Ortmayer } \\
\text { Mining Co. }\end{array}$ & $\begin{array}{l}1952 \\
1953 \\
1954 \\
1955 \\
1956 \\
1957 \\
1958 \\
1959 \\
1960 \\
1961 \\
1962\end{array}$ & $\begin{array}{r}2,305 \\
4,093 \\
4,861 \\
5,823 \\
5,831 \\
6,500 \\
7,843 \\
6,835 \\
6,450 \\
6,750 \\
874\end{array}$ & $\begin{array}{l}0.41 \\
0.38 \\
0.31 \\
0.24 \\
0.23 \\
0.21 \\
0.20 \\
0.24 \\
0.23 \\
0.21 \\
0.16\end{array}$ & \\
\hline & Total & & & 58,162 & 0.25 & 1.80 \\
\hline ML-30 & $\begin{array}{l}\text { Little } \\
\text { Yolanda, } \\
\text { Herbert, } \\
\text { Vanadium, } \\
\text { Ocumpaugh }\end{array}$ & H.R. Watters & $\begin{array}{l}1952 \\
1953 \\
1954 \\
1955 \\
1956 \\
1957 \\
1958\end{array}$ & $\begin{array}{r}2,767 \\
4,198 \\
1,721 \\
2,180 \\
3,039 \\
554 \\
909\end{array}$ & $\begin{array}{l}0.17 \\
0.23 \\
0.25 \\
0.32 \\
0.24 \\
0.26 \\
0.24\end{array}$ & \\
\hline & Total & & & 15,308 & 0.24 & 1.17 \\
\hline ML-32 & $\begin{array}{l}\text { Ellison- } \\
\text { Burro }\end{array}$ & $\begin{array}{c}\text { Blue Creek } \\
\text { Mining Co. }\end{array}$ & $\begin{array}{l}1952 \\
1953 \\
1954 \\
1955 \\
1956 \\
1957\end{array}$ & $\begin{array}{r}73 \\
775 \\
466 \\
220 \\
198 \\
9\end{array}$ & $\begin{array}{l}0.23 \\
0.36 \\
0.45 \\
0.31 \\
0.28 \\
0.33\end{array}$ & \\
\hline & Total & & & 1,741 & 0.36 & 1.67 \\
\hline
\end{tabular}


Table II. Mineral Production from Mineral Leases.-Continued

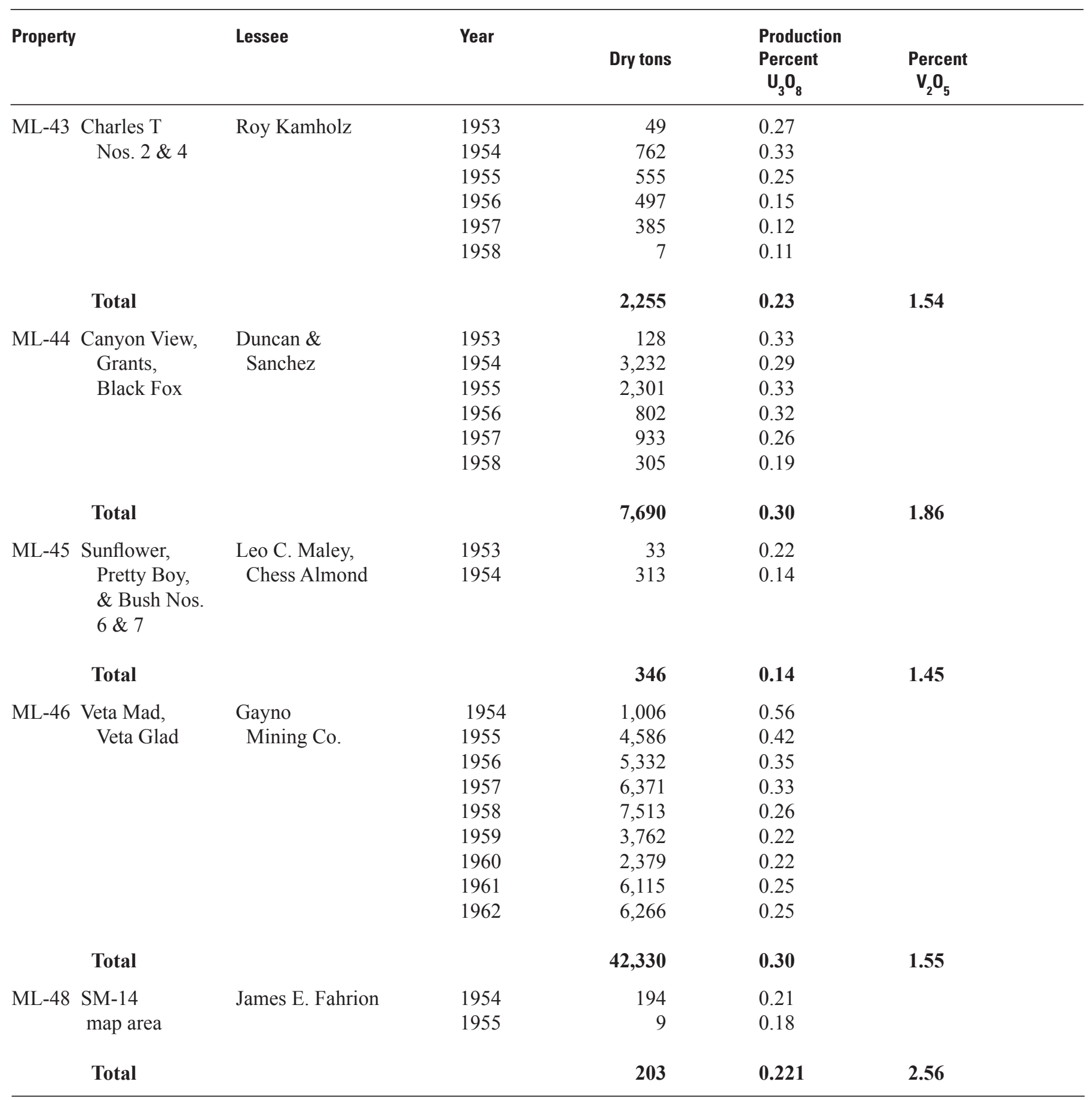


Table III. Uranium-Vanadium Ore Production from San Miguel County, Colorado.

[Excluding production from the Placerville, Colo., district]

Most of the production $(4,839,300$ tons) was from the Slick Rock district; a small part (310,500 tons) came from mines bordering Gypsum Valley just northeast of the Slick Rock district boundary, for a total of 5,149,800 tons. Production data include annual individual mine production derived from AEC Open-File ore-production data 1948-1971, and data available to the author from DOE only on a county-total basis from 1972 to mid-1983. Hence, data for the latter period from San Miguel County northeast of Slick Rock district could not be segregated from that of the district.

\begin{tabular}{|c|c|c|c|c|c|}
\hline Year & Tons of ore & Pounds $\mathrm{U}_{3} \mathrm{O}_{8}$ & Percent $\mathrm{U}_{3} \mathbf{0}_{8}$ & Pounds $\mathrm{V}_{2} \mathrm{O}_{5}$ & Percent $\mathrm{V}_{2} \mathbf{O}_{5}$ \\
\hline $\begin{array}{r}1948- \\
1953\end{array}$ & 289,256 & $1,753,775$ & 0.30 & $11,003,324$ & 1.90 \\
\hline 1954 & 71,783 & 438,700 & 0.31 & $2,592,254$ & 1.81 \\
\hline 1955 & 67,649 & 412,233 & 0.30 & $2,252,099$ & 1.66 \\
\hline 1956 & 76,060 & 449,298 & 0.30 & $2,575,294$ & 1.69 \\
\hline 1957 & 81,103 & 441,341 & 0.27 & $2,757,371$ & 1.70 \\
\hline 1958 & 142,369 & 785,921 & 0.28 & $4,916,043$ & 1.73 \\
\hline 1959 & 161,044 & 830,183 & 0.26 & $5,492,025$ & 1.70 \\
\hline 1960 & 179,398 & 870,795 & 0.24 & $6,278,260$ & 1.75 \\
\hline 1961 & 141,095 & 680,601 & 0.24 & $4,915,661$ & 1.74 \\
\hline 1962 & 136,247 & 640,383 & 0.24 & $4,823,555$ & 1.77 \\
\hline 1963 & 125,870 & 604,728 & 0.24 & $4,611,219$ & 1.83 \\
\hline 1964 & 144,028 & 640,566 & 0.22 & $5,393,870$ & 1.86 \\
\hline 1965 & 144,320 & 673,530 & 0.23 & $5,622,407$ & 1.95 \\
\hline 1966 & 144,252 & 613,960 & 0.21 & $5,074,053$ & 1.76 \\
\hline 1967 & 137,001 & 566,896 & 0.21 & $4,542,802$ & 1.67 \\
\hline 1968 & 148,121 & 559,670 & 0.19 & $4,545,038$ & 1.55 \\
\hline 1969 & 120,487 & 466,547 & 0.19 & $4,016,153$ & 1.67 \\
\hline 1970 & 157,574 & 570,130 & 0.18 & $4,962,415$ & 1.57 \\
\hline 1971 & 163,308 & 573,582 & 0.18 & $4,715,489$ & 1.44 \\
\hline 1972 & 84,296 & 317,539 & 0.19 & $2,566,957$ & 1.52 \\
\hline 1973 & 115,936 & 401,622 & 0.17 & $3,223,382$ & 1.39 \\
\hline 1974 & 177,475 & 571,123 & 0.16 & $4,376,110$ & 1.23 \\
\hline 1975 & 189,257 & 587,183 & 0.16 & $4,623,905$ & 1.22 \\
\hline 1976 & 216,535 & 631,116 & 0.15 & $5,175,066$ & 1.20 \\
\hline 1977 & 226,805 & 644,669 & 0.14 & $4,976,472$ & 1.10 \\
\hline 1978 & 300,302 & $1,071,599$ & 0.18 & $6,456,281$ & 1.07 \\
\hline 1979 & 161,906 & 491,853 & 0.15 & $3,666,808$ & 1.12 \\
\hline 1980 & 283,538 & 820,147 & 0.14 & $5,683,164$ & 1.02 \\
\hline 1981 & 125,694 & 410,076 & 0.16 & $2,218,964$ & 1.17 \\
\hline 1982 & 78,834 & 241,098 & 0.15 & 593,983 & 1.20 \\
\hline $1983^{*}$ & 55,726 & 185,440 & 0.17 & $1,204,235$ & 1.16 \\
\hline
\end{tabular}

* January-June only. 


\section{Appendix B}

\section{Account of Mining in the Slick Rock District, 1965}

[Issued by the Atomic Energy Commission, Grand Junction, Colo. as an unpublished agency report]

Mining activity in the Slick Rock district in the early part of 1965 is an example of the level and variety of operations at that time. Union Carbide Nuclear Co. continued to operate the Deremo mine at an accelerated rate. Production from the mine averaged about 9,000 tons per month (tpm) during the first three months of the year. The operator had more than 10,000 tons stockpiled at the mine on March 17, 1965. Cleghorn and Bond, contractors at Union Carbide's Burro No. 1 mine, had two miners employed driving 1,700 feet of development drifts to ore holes on the west end of the mine. In late March 1965, contractors were driving 2 headings, one in a northwest direction to intersect ore holes and the other to the northeast to connect with old mine workings. Phil Bunker continued to mine from Shaft No. 7 of the Burro claims, with 20 men. They had 700 tons of ore stockpiled at the mine on March 17, 1965.

Dulaney Mining Co. had 41 men working on the Radium group of mines and production continued at 1,200-1,500 tpm. The company was sinking a 240 -foot incline on the Bean
No. 8 claim and had about 100 feet remaining to reach an ore body. A 400-foot development drift was being driven on a 3 -shift basis to a large ore body discovered by drilling on the Sunrise claim and on patented land. Drilling indicated that the ore body was 60-70 feet wide and about 350 feet long. Fritz-Erickson Mining Co. terminated mining operations at the Ava Jay mine and planned to drill 40-50 holes on the claims during the following months. The company reopened the old Hangover mine and planned to drift to ore holes drilled during late 1964. The operator anticipated ore with a thickness of 2.5 feet, and planned to start production in March 1965. Baird and Robinett, sublessee from Fritz-Erickson Mining Company's Hawk-Frankie group of mines, completed a 150-foot drift to ore holes drilled in 1964. Ore was spotty, and operations were pending termination. Ed Hughes drove drifts to intersect ore holes at the Chief mine, but ore bodies were small, and termination of operations was contemplated. (Data from Atomic Energy Commission file reports, 1965.) 


\section{Appendix C}

\section{Chemical Formulas of Minerals Described in this Report (from Gaines and others, 1997)}

Anatase $\mathrm{TiO}_{2}$

Apatite $(\mathrm{CaCl}) \mathrm{Ca}_{4}\left(\mathrm{PO}_{4}\right)_{3}$

Azurite $2 \mathrm{CuCO}_{3} \cdot \mathrm{Cu}(\mathrm{OH})_{2}$

Barite $\mathrm{BaSO}_{4}$

Biotite $\mathrm{H}_{2} \mathrm{~K}(\mathrm{Mg}, \mathrm{Fe})_{3} \mathrm{Al}\left(\mathrm{SiO}_{4}\right)_{3}$

Bornite $\mathrm{Cu}_{5} \mathrm{FeS}_{4}$

Calcite $\mathrm{CaCO}_{3}$

Carnotite $\mathrm{K}_{2}\left(\mathrm{UO}_{2}\right)_{2}\left(\mathrm{~V}_{2} \mathrm{O}_{8}\right) \cdot 1-3 \mathrm{H}_{2} \mathrm{O}$

Chalcedony $\mathrm{SiO}_{2}$

Chalcocite $\mathrm{Cu}_{2} \mathrm{~S}$

Chalcopyrite $\mathrm{CuFeS}_{2}$

Clausthalite $\mathrm{PbSe}$

Clay (including vanadium- and chromium-bearing types)

Coffinite $\mathrm{U}\left(\mathrm{SiO}_{4}\right)_{1-\mathrm{x}}(\mathrm{OH})_{4 \mathrm{x}}$

Corvusite group $(\mathrm{Na}, \mathrm{Ca}, \mathrm{K}) \mathrm{V}_{8} \mathrm{O}_{2} \cdot 4 \mathrm{H}_{2} \mathrm{O}$

Digenite $\mathrm{Cu}_{1.8} \mathrm{~S}$ (chalcocite) $\left(\mathrm{Cu}_{1.8} \mathrm{~S}\right)$

Doloresite $\mathrm{H}_{8} \mathrm{~V}_{6} \mathrm{O}_{16}$

Dryscolite $\mathrm{MoSe}_{2}$

Eucairite $\mathrm{Cu}_{2} \mathrm{Se} \cdot \mathrm{Ag}_{2} \mathrm{Se}$

Ferroselite FeSe

Galena $\mathrm{PbS}$

Garnet $\left(\mathrm{Ca}, \mathrm{Mg}, \mathrm{Fe}_{3}\right) \mathrm{Al}_{2}(\mathrm{SiO} 4)_{3}$

Goethite $\mathrm{FeO}(\mathrm{OH}) ; \mathrm{Fe}_{2} \mathrm{O}_{3} \cdot \mathrm{H}_{2} \mathrm{O}$

Gypsum $\mathrm{CaSO}_{4} \cdot 2 \mathrm{H}_{2} \mathrm{O}$

Hematite $\mathrm{Fe}_{2} \mathrm{O}_{3}$

Hewettite $\mathrm{CaO} \cdot 3 \mathrm{~V}_{2} \cdot 9 \mathrm{H}_{2} \mathrm{O}$

Hydrated iron oxide
Illite (hydromuscovite)-smectite (phyllosilicate "clay")

Ilmenite $\mathrm{FeTiO}_{3}$

Lepidocrocite Dimorphous goethite

Leucoxene $\mathrm{TiO}_{2}$

Limonite $2 \mathrm{Fe}_{2} \mathrm{O}_{3} \cdot 3 \mathrm{H}_{2} \mathrm{O}$

Magnetite $\mathrm{FeO} \cdot \mathrm{Fe}_{2} \mathrm{O}_{3}$

Malachite $\mathrm{CuCO}_{3} \cdot \mathrm{Cu}(\mathrm{OH})_{2}$

Montmorillonite (bentonite) $(\mathrm{Mg}, \mathrm{Ca}) \mathrm{O} \cdot \mathrm{Al}_{2} \mathrm{O}_{3} \cdot 5 \mathrm{SiO}_{2} \cdot n \mathrm{H}_{2} \mathrm{O}$

Montroseite $(\mathrm{V}, \mathrm{Fe}) \mathrm{O}(\mathrm{OH})$

Native selenium $\mathrm{Se}$

Naumannite $\mathrm{Ag}_{2} \mathrm{Se}$

Paramontroseite $\mathrm{VO}_{2}$

Pascoite $\mathrm{Ca}_{3}\left(\mathrm{~V}_{10} \mathrm{O}_{28}\right) \cdot 17 \mathrm{H}_{2} \mathrm{O}$

Pyrite $\mathrm{FeS}_{2}$

Quartz $\mathrm{SiO}_{2}$

Roscoelite $\mathrm{K}\left(\mathrm{V}^{3+}, \mathrm{Al}, \mathrm{Mg}\right)\left[(\mathrm{Si}, \mathrm{Al})_{4} \mathrm{O}_{10}\right](\mathrm{OH})_{2}$

Rutile $\mathrm{TiO}_{2}$

Sphalerite $\mathrm{ZnS}$

Tourmaline Complex silicate of B and Al, with $\mathrm{Mg}, \mathrm{Fe}, \mathrm{K}$, or Na prominent

Tyuyamunite $\mathrm{Ca}\left(\mathrm{UO}_{2}\right)_{2} \mathrm{~V}_{2} \mathrm{O}_{8} \cdot 5-8 \mathrm{H}_{2} \mathrm{O}$

Uraninite $\mathrm{UO}_{2}$ (with $\mathrm{Pb}, \mathrm{Th}, \mathrm{Zr}$ )

Vanadian chlorite (Vanadium-bearing chlorite)

Vanadian hydromica (vanadium-bearing hydrous mica)

Volborthite $\mathrm{Cu}_{3} \mathrm{~V}_{2} \mathrm{O}_{7}(\mathrm{OH})_{2} \cdot 2 \mathrm{H}_{2} \mathrm{O}$

Volkonscoite? Chromium-bearing clay

Zircon $\mathrm{ZrSiO}_{4}$ 